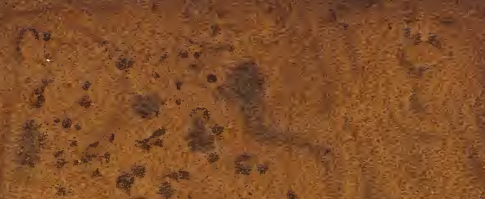

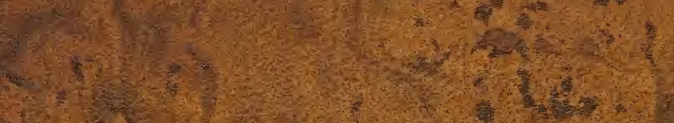

(1)

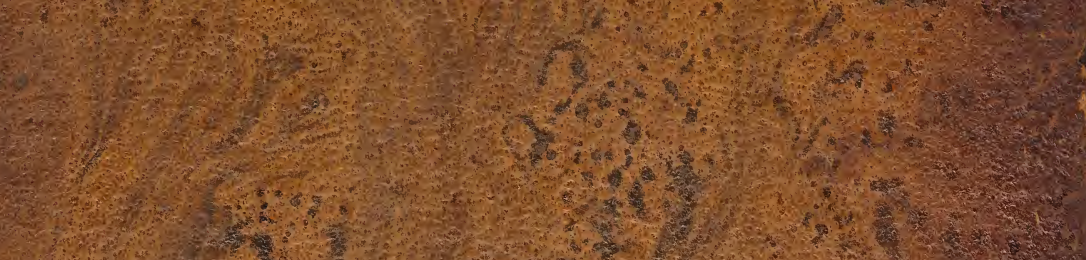

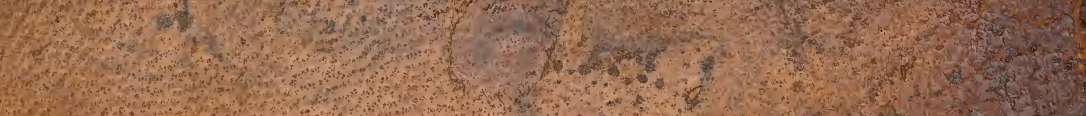

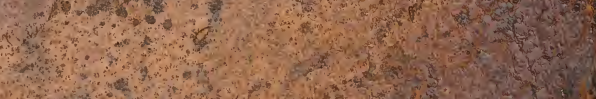

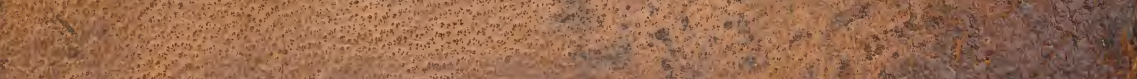



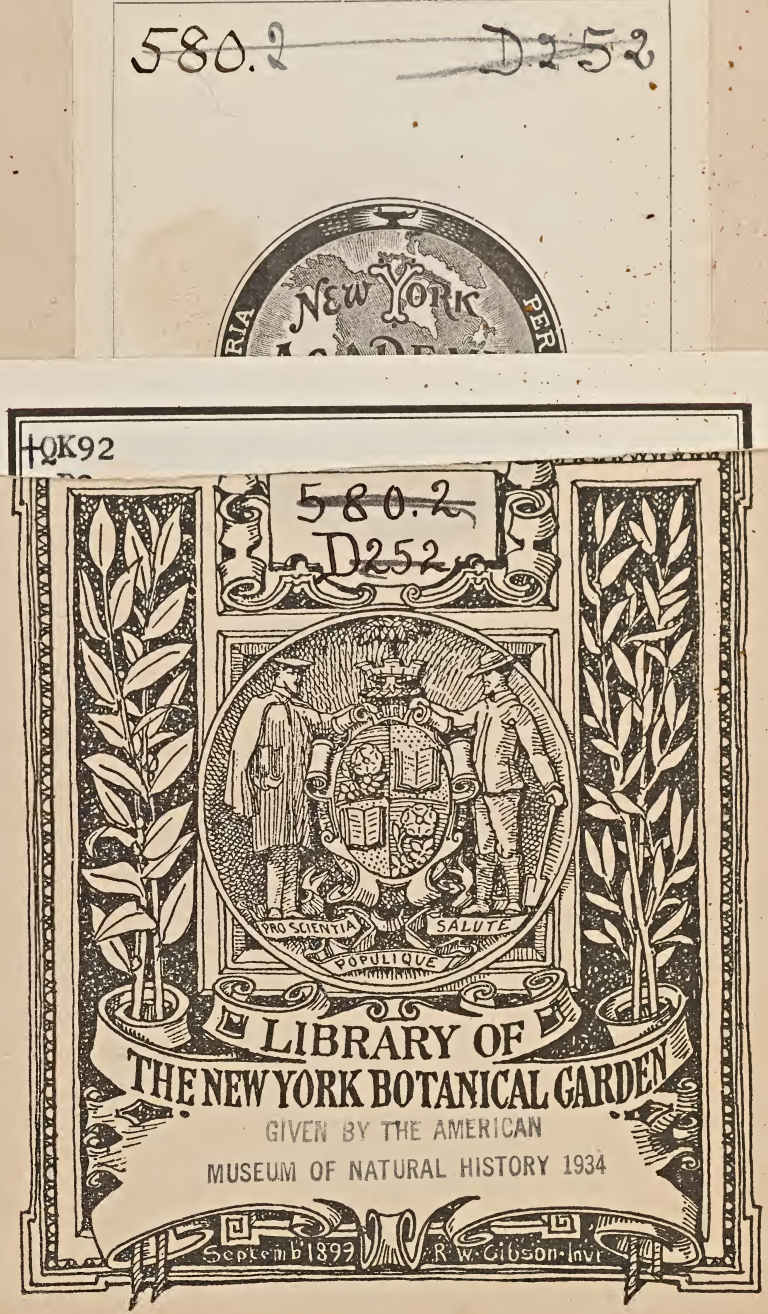



<smiles>C=[V]</smiles> 


\section{PRINCIPIA BOTANICA:}

Or, a Concise and Easy

\section{INTRODUCTION}

\section{TO THE \\ SEXUAL BOTAN OY OIINN AEUS.}

Containing

THE GENERA;

THEIR MODE ÓF, GHOWTH (AS TREE, SHRUB, OR HERB);

THE KNOWN NUMBER OF SPECIES TO EACH GENUS;

WHERE PRINCIPALLX NATIVE; AND

THE NUMBER INDIGENOUS TO THEBRITISH ISLES :

\section{Olreanged infor cautula Jorm,}

UNDER EACH CLASS AND ORDER;

And

DIGESTED ALPHABETICALLY UNDER SEN
GENERIC DISTINCTIONS.

Together with

THREE INDEXESOSCIENC OAS.

1. Of the LINN $Æ A N$ GENERA accented, with the BRITISH NAMES\% w w

II. Of such TRIVIAL NAMES as were the GENERA of OLD AUTHORS.

III. Of the BRITISH NAMES, with the IINN IEAN GENERA; to whigh IBRARY are added the SPECIFIC NAMES.

ALSO

NEW YORK
A TABLE OF VEGETABLE DRUGS, NOT IN THE INDEXES.
BOTANICAL.
QARDEN

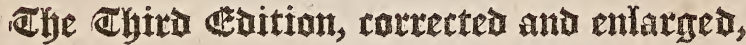

With many curious and useful additional Notes.

And he spake of Trees, from the Cedar that groweth in Lebanon, even unto the Hyssop that springeth out of the wall............ KInGS, iv. 33 .

N E WA R K :

Printed and sold by M. Hage.

Sold also by Messrs. LONGMAN, HURST, REES, and ORME,

Paternoster Row, LONDON, and all other Booksellers.

1810. 


$$
\begin{gathered}
+Q K 92 \\
D 3 \\
1810
\end{gathered}
$$




\section{TO \\ ROBERT WARING DARWIN, \\ M.D.\& F.R.S.}

As the Science of BOTANY has always been intimately connected with the Science of MEDICINE, I make no Apology for taking the Liberty of addressing this third Edition of the . PRINCIPIA BOTANICA to one so eminent in his Profession. It also indicates a just Tribute to his Abilities and Merit; and a sincere Testimony of the high Esteem and Regard of his truly affectionate Uncle,

\section{Robert Waring Darwin.}




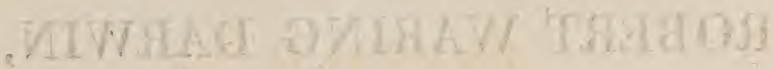

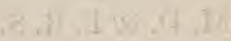

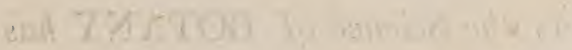

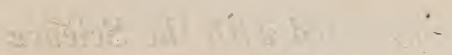

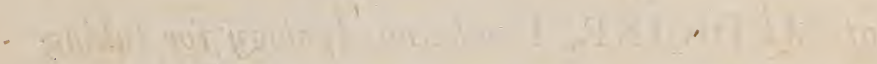

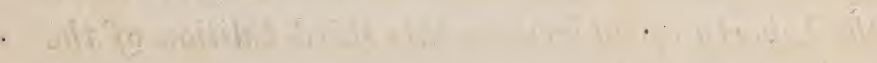

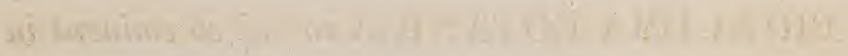

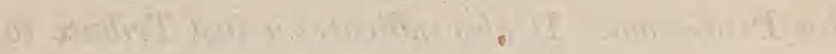

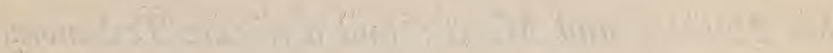

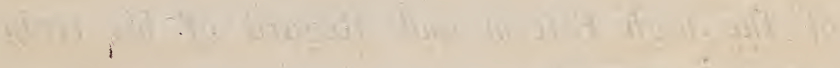

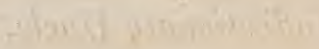

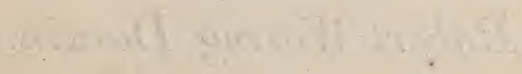




\section{PREFACE.}

I may seem unnecessary to attempt an introduction to Botany, after so laborious and established a performance as that of Mr. Lee; but as that work is very diffuse, and more proper for an adept in the science, than a young student; it was thought a more easy way of inculcating the first principles might be adopted on a less scale; and by confining the necessary matter to each respective head, the whole might be so contracted as to give a general idea of the system at one view ; and the mind not left 业 at large to expatiate over an unbounded prosz ends in disgust.

Another reason also occurred to render this attempt necessary; that the price might be so 
low, as not to deter those in less affuent circumstances from entering into the paths of Nature; and therefore the plates of the several parts of the fructification, the forms of the leaves, \&c. (which may be seen in every larger publication of Botany) are omitted; as are also the several tables of scientific terms, which, as far as is necessary, will be easily acquired in a further progress.*

By these means it is hoped to encourage a more extensive inquiry into the science; for nothing is more pleasing and instructive to the human mind than to contemplate the barmony of Creation, as nothing more strongly evinces the existence of a Supreme Cause.

It is impossible for the most laboured harangues, or the most subtle reasoning, to make

* Linnæus hath no good plates to explain his system, but if thought necessary, plates may be seen in many of the English publications on Botany, and especially in Rose's Elements of Botany, which contain the principal parts of the Plilosophia Botanica of Linnæus; and very proper to be perused, after a general idea of the system is obtained. 
so deep and lasting impressions in the mind, as the works themselves; and no part of Natural Mistory is more inviting than the science of Botany, as the objects of it continually surround us, and present themselves before our eyes in the most beautiful attire; many of them indeed leave us in Autumn, and go into Winter quarters, but, like the parting of friends, the pleasure is enhanced by our meeting again in the ensuing Spring: neither is any part of Natural History more useful for the most important purposes of life, as food, drink, raiment, \&c. but what is still more valuable, health; for it supplies us with a very essential part of the Materia Medica.

It is curious to observe the several ways $\mathrm{Na}$ ture hath chosen for the protection of those plants she hath designed for particular purposes ; some she hath armed with thorns, prickles, or stings, as a defence against the larger animals; others emit a viscous matter to annoy the voracious insect; others are guarded with bitter, acrid, or narcotic juices; she hath also given to plants and flowers agreeable and disagreeable odours, which are owing to the exha- 


\section{lation of their essential oils; * all intended as}

* Oils of plants are obtained either by expression, where the oil is very copious, as in rape, linseed, \&c. or by infusion,-and the oil extracted by distillation, or insolation; by which latter methods the fine essential qualities of the plant are preserved, and are hence called essential oils (see note to dyctamnus); which may be divided into two classes according to their specific gravities; some floating upon water, as lavender, mint, marjoram, citron-peel, roses, \&c.; others sinking to the bottom, as cloves, cinnamon, sassafras, \&c.-Dr. Molrro, in his Treatise on Chymistry, v. ii. p. 311, hath given the method of preparing the essential oil of roses, as it is done in the East Indies, called the ottar of roses. - Take a very large earthen or stone jar, or a large clean wooden vessel; fill it with the leaves of the flowers of roses, very well picked, and freed from all seeds and stalks; pour on them as much pure spring water as will cover them, and set the vessel in the sun in the morning at sun rise, and let it stand till the evening, then take it into the house for the night; expose it in this manner for six or seven successive days, and at the end of the third or fourth day, a number of particles of a fine yellow oily matter will foat on the surface, which in two or three days more will gather into a scum, which is the ottar of roses: this is taken up by some cotton, tied to the end of a piece of stick, and squeezed with the finger and thumb into a small phial, which is immediately well stopped; and this is repeated for some successive evenings, or while any of this fine essential oil rises to the surface of the water.

This oil is said to be sold at a guinea a drop in the East Indies.

Trans. of the R. S. Edinb. vol. 2.

The monks of St. Mark's Convent at Florence, are said to make very good ottar of roses for about eight pounds sterling an ounce.

Smith's Tour on the Continent, printed 1793.

The word ottar, used by the Asiatics to express the essence of roses, is originally Arabic; and signifies an aromatic odour or perfume in general. 
PREFACE.

weapons of defence against the depredations of a variety of animals, which would otherwise frustrate some higher intention.

Many of these plants, by the long experience of mankind, have already been converted into medicine, and other useful purposes; and by the diffusion of botanical science, it is hoped, in many others, the virtues which yet lie dormant will be awakened; and that those plants which are now ranked amongst destructive poisons, will gradually be reclaimed, and become a valuable acquisition to the science of medicine.

The analogy of plants as to their virtues, is well worth the enquiry of some able botanist, as the same virtues which are observed in a genus, do in a great measure run through all the species; and in some cases a whole order, and even a whole class, if natural, will have the same predominant virtue.**

* Tournefort had a very easy method to discover the acid or aikalinc quality of plants; he made use of a deep blue paper, which being moistened with the juice of the plant, shewed its quality; with an 'acid $i t$ becomes red, with an alkali, green.-A vegetable blue will 
It is hoped also some able enquirer into $\mathrm{Na}$ ture, will think it worthy attention to investigate the analogy and connexion between vegetables and minerals; and whether there exists such a sensible analogy, that by inspecting the plants which grow naturally on the surface of any place, the quality of the soil may be discovered, as also the several sorts of minerals it may contain.*

\section{R. W. D.}

Eilston,
Notts.

in general turn red with acid (indigo is an exception, being soluble in acid; as is also the ront of the mercurialis perennis, which, by exposure to the air, will frequently become a brilliant blue), hence we observe a red colour developed in vegetables, in which an acid continually acts, as in the leaves of sorrel, vine, \&c.-Nicholson's translation of M. Chaptal's Elements of Chymistry, in 3 vols. printed 1791.

* The lichen calcarius receives its name from its peculiarity in growing on lime stone rocks; that wherever that stone occurs amongst others, it may be distinguished by this plant growing upon it.

Dillon's Travels through Spain, printed 1782.

The digitalis and arenaria are found on sandy soils, and others are only found on boggy and marshy soils; as the rubus chamcemorus (cloul-berry), and the raccinum oxycoccos (cranberry) are found on peat bogs. 


\section{ADVERTISEMENT.}

Is this Edition, the errors of the former are corrected; the number of genera is taken from the sth edition of the Genera Plantarum, by Thaddæus Haenke, member of the Scientific Society at Prague, printed in 1791; which includes all the genera (amounting to 1683 ) discovered to that time, by Linnæus, Forster, Thunberg, L. Heritier, Swartius, Aiton, and others.-In this edition of the genera (and it is said by the instruction of Dr. Thunberg) four of the original classes of Linnæus are omitted, viz. gynandria, monøcia, diocia, and polygamia'; as also the appendix: And the several genera are incorporated with the other classes according to the number of males and females to each genus: But the crowding the regular classes with plants of such different singularities in their sexual disposition, seems such a mutilation of the Linnatan Srstem, as I cannot approve of, till sanctioned by more general authority; for it seems much more pleasing. to see plants of particular singularities ranged together; besides the great confusion and inconvenience that will arise to all modern writers who have adopted the regular system of Linnæus, which hath now been long established and approved. The number of species is taken from the 14th edition of the Systema Vegetabilium, by Dr. Murray, printed in 1784, which includes all the genera and species of Linnæus the elder, and 
Linnæus the younger, with a few others.-Also several notes and observations are added, and the specific names to the genera in the Index of British Names; together with the British names to the Genera of Old Authors.-And that the Science may be divested of indelicacy in an English dress, for the word bastard, which frequently occurs in Botany, the word base is substituted; and the word hermaphrodite is entirely discarded; and instead thereof, the word monoclinia (one bed) which Linnæus makes use of in his Key to the Sexual System (called the nuptials of plants) is in general adopted (in allusion to the marriage state) in all those classes where husband and wife are in the same bed or flower; for in such the sexes are not united, but stand separate and distinct; each flower being perfect in its kind; whereas the word hermaphrodite (in our language) implies imperfection, and gives a very disagreeable idea, as also greatly lessens the affinity in the sexual analogy between plants and animals, which is the basis of the system; if any flowers can with propriety deserve the excluded appellation, they are those of the class gynandria, 


\section{PRINCIPIA BOTANICA.}

No part of natural history hath employed the pens of so many writers, as the science of BOTANY, in order to distinguish and methodize the great variety of plants.

The systems most in esteem for this purpose, before Lin- næus, were those of Ray and Tournefort. Ray is said to have described 18655 species, including varieties; and his method of arrangement was founded upon the general habit or structure of plants, their growth, as trees, herbs, \&c. their greater or less degree of perfection, the number of petals, seed-leaves, and various other circumstances, which he arranged in 33 classes.

Tournefort's method is chiefly founded upon the figure of the petals, which is preferable in that respect to others, figure being more constant than number: His classes are 22 , subdivided into 698 genera, which are again subdivided into $\mathbf{3 0 1 4 6}$ species and varieties.

But the SEXUAL SYSTEM of LiN N 20 s hath now superseded all others, by its concise and elegant arrangement, and by shewing the great analogy and nice connexion between plants and animals: It is founded on the difference in the sexes* of plants, and is divided into 24 classes, which are

* The ancients, as Theophrastus, Dioscorides, Aristotle, Herodotus, and Pliny, as well as the modern botanists, were well aware of the sexes in many plants, and thence concluded it might be the same in all; but the full investigation, and classing them according to their sexes, was reseryed for Linnæus. 
subdivided into several orders, and under the orders are ranked the respective genera, , with their attendint species: The names of the classes and orders are chiefly derived from the Greek, those of the first 13 classes being expressive of the number of stamina or males in a flower; and those of the orders, of the number of pistilla or females in a flower; and the names of the other classes and orders, are also particularly expressive of the circumstances attending the males or females of the genera under each respective class and order. $\uparrow$

Therefore to investigate a plant, we must first find the class and order to which it belongs, $\downarrow$ for that is the grand foundation of the system; next we must find the distinction in that order; and then (by Linnæus's description) the gemus or family, $\S$ and afterwards the several species or relations; for

* In the oth edition of Linnæus's Genera Plantarum are described 1239 generd, which have since been augmented to 1444 . - See the 13 th edition of the Systemas Vegetabilium. To which a few more are added in the 14 th edition.-And under the several genera are the following number of species in each class, besides varieties.

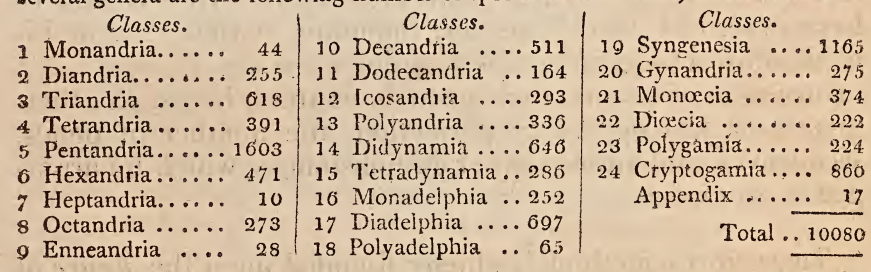

By this table it appears that, in the vegetable system, nature seems most to delight in the number 5 ; see the classes pentandria and syngenesia, $8 \mathrm{c}$.

+ Dr. Darwin thinks that if all the classes of plants had been distinguished by the proportion, situation, and disposition of the stamina, along with the number, the arrangement would have been more natural, than by number alone; as being less liable to variation; and he gives several examples.-Many of the orders alsd he thinks would admit of more plain essential characters (added to the present distinction) from the proportion and length of the style, compared with the stamina, and from several other peculiar circumstances attending the style and stigma; several examples of which are given, and by which a plant would be more easily found, and the orders be more natural.

Phytologia.

¥ The class and order of any plant may generally be found by the explanation of the classes and orders.

$\S$ The word genus, in natural history, is aptly compared to a family, with reference to some higher distinction; it is only an abstract idea expressed by some general name or term, comprehending a greater or less number of species or relations, bearing the same sir-name, as resembling each other in certain established characters, or at least in some essential parts; though distinguished by different specific names. 
the genera include a great number of relative species, distinguished by the specific difference of the root, the trunk, the branches, the leaves, \&c. (yet all agreeing in the essential generic character) and are called by trivial names (expressive of the difference, or some other circumstances) added to the generic name.

The essence of every vegetable, says Linnæus, consists in the fructification (or mode of fruit-bearing) and the essence of the fructification consists in the flower and fruit; the essence of the flower consists in the antheræ and stigma, and the essence of the fruit consists in the seed: Hence in his Sexual Theory, he necessarily makes the flower and fruit the foundation of his generic distinctions, and these are generally composed of seven parts.

\begin{tabular}{l|l} 
ist, The CALYX. & 4th, The PISTILLUM. \\
2d, The COROLLA. & 5th, The PERICARPIUM. \\
3d, The STAMINA. & 6th, The SEMINA. \\
7th, The RECEPTACULUM.
\end{tabular}

And the presence or absence, the number, figure, proportion and situation of the several parts, constitute the genus : but as there are few genera wherein all the parts of the generic or natural character are constant in every one of the species; Linnæus found it necessary to fix upon such circumstances as are constant in both genus and species, and call those the essential or ruling character; as well the more easily to distinguish one genus from another, as to regulate and fix the several species and their varieties to their respective genera; $*$ for which purpose, in some cases, he was obliged to have recourse to the nectarium.

* This variation renders the system incomplete (though perhaps it is the best hitherto formed) from the difficulty arizing in adapting a plant to its proper class and order, as in one of the species of the horse-chesnut (A Eseulus pavia) though it is of the class heptandria, hath eight stamina; and so of several others ; as lychnis dioica, hypericum, cleome, \&c.

+ See nectarium explained under corolla: And see the Gen. Plantarum, for a particular description of each genus, according to the natural character : And see the Systema Vegetalilizm, where the genera and species are discriminated according to their essential and specific differences; under several generic and specific distinctions. 
The first four parts of the fructification are properly parts of the flower, and the last three are parts of the fruit.

I. The CALYX* (a cup) is the termination of the outer bark (cortex) of a plant, and its chief use is to enclose, support, and protect the other parts of the fructification; when present, it is generally seated on the receptacle, and is distinguished by its figure, and by the number, division, and shape of its leaves or segments; and by the following names, according to the circumstances with which it is attended.

1st. Perianthium, (surrounding the flower) when its station is close to, and surrounds the other parts of the fructification, and it is then called the perianthium of the fructification: If it includes many florets, as in scabiosa, and other aggregate and compound flowers, it is called a common perianthium ; if it includes only one floret, in such flowers, it is called a proper perianthium; if it includes the stamina, and not the germen, $\uparrow$ it is the perianthium of the flower, and is said to be above, as in lonicera, ribes, campanula, pyrus, \&c. if it includes the germen, but not the stamina, it is the perianthium of the fruit, and is said to be below, as in linnea and morina, each of which have two calyxes and two receptacles above each other, one of the flower and the other of the fruit; and may therefore serve as instances in both cases. $f$

2d. INvolucrum (a cover) when stationed at the foot of an umbel below the common receptacle, and at a distance

* The caly $x$ is considered a part of the flower, though it more generally attends, and is permanent with the fruit; as in the class didynamia, and most other plants; yet sometimes it drops before or with the corolla, and before the fruit is ripe ; as in the class tetradynamia, and many other plants. It is also considered a part of the flower, as there is no instance of its coming out after the plant hath done flowering; yet in patagomula it is observed to grow to a much larger size in the fruit, than it had in the flower : In some plants there is none, (when the petals are strong, as in the tulip, \&c.) or scarce perceptible; in others it is only a rim or border (margo). The germen is also considered as part of the flower, as being the base of the pistillum, though it afterwards becomes the seed-vessels.

\section{$\uparrow$ See germen under pistillum.}

¥ When the calyx is a perianthium, it generally corresponds with the petals of the corolla, as to the number of its leaves, but not always, as in fragaria, \&c. 
from the flower; and it is called aniversal, if placed under the universal umbel, and partial, if placed under a partial umbel.*

3d. Amentum (a thong, meaning a catkin) when it consists of a great number of chaffy scales, disposed along a slender axis or common receptacle, which from its resemblance to a cat's tail, hath obtained the name of catkin; and these flowers have generally no petals: Sometimes the same amentum supports both male and female flowers, distinct, on the same plant, as in carpinus, \&c.; sometimes the male and female flowers are removed from each other on the same plant, and the amentum supports only the male flowers, and the female flowers are enclosed by a perianthium, as in corylus, juglans, fagus, \&c.; and sometimes an amentum only supports male Howers on one plant, and female flowers on another plant, as salix, populus, \&c.

4th. SPAтн A (a sheath) being a sort of calyx growing from the stalk, bursting lengthways, and protruding a spadix, $\uparrow$ or receptacle, supporting one or more flowers, which have often no perianthium; and consists either of one leaf, with a valve or opening on one side only, as in narcissus, galanthus, and the greater number of spathaceous plants; or of two leaves, with two valves or openings, as in stratiotes, \&c.; or is imbricated, as in musa, \&c. with one or two valves.

5th. Giuma (a husk) this chiefly belongs to corn and grasses, consisting of one, two, three, or more valves, folding over each other like scales, and frequently terminated by a long, stiff, pointed prickle, called the arista (beard or awn).

6th. Calyptra (a veil or covering) the proper calyx to mosses; it is placed over the anthera of the stanina, resembling an extinguisher, a hood, or monk's cowl.

* See umbellate flowers under distinction of flowering.

In umbellate flowers several want both the universal and partial involucrum ; as parsnip, herl-gerard, lurnet-saxifrage, dill, \&c.; and some have only a partial involucrum, as shepherd's-needle, chervel, master-wort, \&c.

+ See spadix under receptaculzim. 
7th. Vouva* (from its infolding or involving) the proper calyx to fungusses being membranaceous, and surromding the stalk or pillar before their expansion.

N. B. It is often difficult to distinguish the calyx from the bractec (sometimes called floral leaves) which are found on many plants, situated on the flower stalks; and are often so near to the lower parts of the fructification, as to be confounded with, and mistaken for the calyx, as in tilia, helleborus, passifora, \&e.; (in helleborus the calyx is wanting) but they may be best distinguished by this rule; the bractea are scales or small leaves, which differ in size, shape, and colour, from the other leaves of the plant, but are commonly of the sane duration; whereas the calyx always withers when the fruit is ripe, if not before.

See bractea, under PROPs, postea.

II. The COROLLA (a wreath or little crown) is the termination of the inner bark (liber) of the plant; which accompanies the fructification, in the form of leaves variously coloured: it is generally seated on the receptacle, sometimes on the calyx, serving as an inncr work of defence to the part it encloses; as the calyx, which is usually of stronger texture, does for an outer work. The leaves of which the corolla is composed are called petals, by the number, division, and shape of which it is distinguished; and the corolla is said to be below, when it includes the germen, and is attached to the part immediately below it, as in salvia, borago, convolvulus, primula, \&ic.; and it is said to be above, when it is placed above the germen, as in lonicera, ribes, cratcegus, \&c. In respect to duration, the corolla either continues till the fruit is ripe, as in nymphaa; or falls off at the first apening of the

* Volva, though mentioned as a calyx to fungusses, yet in the Genera Plantre $r u m$, it is not once taken notice of in the description of those genera. In Dr. Alston's Tyrocinium Botanicum, published at Edinburgh in 1753 , are enumerated the several calyxes of each sort, from a former edition of the Gen. Pl. then containing 1021 genera; 673 of which have a perianthium ; 75 an involucrum; 18 an amentum ; 72 a spatha; 29 a gluma; 3 a calyptra; 25 have both a perianthium and involucrum; and a few have both perianthium and spatha. In eriophorum ryris, cyperus, and scirpus, the spike is the calyx; in marinda and eringium, the common receptacle is the calyx; and about 110 have no calyx, or very imperfect. 
flower, as in actan, thatictrum, or falls off with the stamina, and other parts of the flower, as in most plants; or does not fall, but withers, as in campanula, cucumis, and others.

There is also a part which, Linnæus says, principally belongs to the corolla, as an appendage to the petals; which he calls the NECTARIUM, * (from nectar, the fabled drink of the gods) and is that part containing the honey, which is the principal food of bees, and other insects; but, though in such plants where it is found, it may more commonly be attached to the corolla, and be then most evident; ret it is almost as oft attached to other parts of the fructification; Linnaus therefore chiefly makes use of it, as an essential character in many of the genera, as being less variable than his other distinctions, as in ranunculus, and parnassia palustris, \&.c. + and observes that when it is distinct from the petals (that is) not united with their substance, those plants are generally poisonous: The tube or lower part of the flowers of one petal, he considers as a true nectarium, because it contains a sweet liquor. But as it affords very singular varieties in other instances, it hath obtained the following distinctions.

1st. CALYCINE NECTARIA, such as are situated upon, and make part of the calyx, as in tropaolum, monotropa, \&c.

2d. Corollaceous Nectaria, such as are attached to the corolla; and are called calcariate (from calcar) when they resemble a spur or horn; which are either on flowers of one petal, as in valeviana, antirrhinum, \&c. or on flowers of many petals, as in orchis, delphinium, viola, fumaria, \&c.: Or the nectarium lies within the substance of the petals, as in fritillaria, lilium, berberis, iris, ranunculus, \&c.

* The proper use of the nectarium, and why it should have such very different situations, is not yet cercainly known: but as it is found in most plants, there is great reason to believe it an essential part in the fructification, though not always perceptible. Pontedera inagined the balsam contained in the nectatiun was imbibed by the seeds, to make them keep and preserve their vegetative quality the longer, and as long as this baisam remained in the seeds, so long they would generate.

+ In Parnassia palustris, the 5 nectaries are very beautiful, each having an hearted concave scale, fringed with 13 pedicles along its margin rising gradually higher, and each terminated by a transparent globe. 
3d. Stamineous nectaria, such as attend the stamina, and are either seated upon the anthera, as in adenanthera; or upon the filaments, as in laurus, dictamnus, campanula, \&ic.

4th. Pistillaceous Nectaria, such as accompany the pistillum and are placed upon the germen, as in hyacinthus, butomus, cheiranthus, hesperis, \&c.

5th. RecEPTACULACEOUS NECTARIA, such as join to the receptacle, as in polygonum, sedum, sempervivum, \&c.

6th. NECTARI a that crown the corolla, that is, when placed in a series or row within the petals, thongh entirely unconnected with their substance, as in passiftora, lychnis, silene, \&c.; and in this situation it often resembles a cup, as in narcissus, \&c.

7th. Nectaria of singular construction, being such as cannot properly be placed under any of the foregoing distinctions, as in amomum, curcuma, salix, urtica, \&c.

III. The STAMINA. (threads or chives). These are the males of the flower, proceeding from the wood of the plant, each stamen consisting of two parts, (viz.) the filament and the anthera; and in most flowers are placed upon the receptacle, within the corolla, and round the germen; and are chiefly distinguished by number.

The FILAMENT (from filum, a thread) is the thread-shaped part of the stamen, serving as a footstalk to clevate the antheræ, and is sometimes found to have jags or divisions, (lacinia) which are either two, as in salvia; three, as in fumaria; or nine, as in the class diadelphia. They are also distinguished by their form or figure, as awl-shaped, threadshaped, hair-like, spiral, revolute, \&c.; also by their proportion, as equal, unequal, irregular, long, or short; also by their situation, being generally opposite to the leaves or divisions of the calyx, and alternate with the petals; that is, when the divisions of the calyx are equal in number to the petals, and to the stamina.* In flowers of one petal

* By this rule it may generally be known whether calyx or corolla be wanting, when there is a deficiency in either. But in aletris the stamens are an exception 
(monopetalous) they are generally inserted into the corolla; but scarcely ever in flowers of more than one petal, (polypetalous) but into the receptacle. Yet in the class icosandria, they are inserted into the calyx or corolla, (though the flowers bave many petals) as also in a few other plants. 'But in the class polyardria, and most other plants of many petals, they are inserted into the receptacle, like the calyx and corolla. But the class gynandria is an exception to the above rules, where the stamina are placed upon the pistillum, or female part of the flower; and are sometimes without filaments.

The Antuera, (from anthos, a flower) emphatically so called, from its great utility in the fructification, is the top or summit of the filament, containing the impregnating pollen or farina; ${ }^{*}$ and is either one to each filament, as in most plants; or one common to three filaments, as in cucurbita, \&c.; or one common to five flaments, as in the whole class syngenesia; or sometimes there are two antheræ to each filament, as in ranunculus, and merurialis; three to each filament, as in fumaria; five to three filaments, as in bryonia; or five to each filament, as in theobroma. The anthera is also distinguished by its form or figure, as oblong, round, angular, \&c. It also consists of one or more cells, which burst differently in different plants; either on the side, as in most plants; on the top; or from the top to the base. It is also fastened to the top of the flament, either by its base, as in most plants; or horizontally, by its middle, to the top of the filament, so poised. as to turn like a fane (versatillis); or it is fixed by its side, leaning to the top of the filament, then called incumbent; or it sometimes grows to the nectarium, as in costus; to the receptacle, as in arum; to the pistillum, as in the class gynandria.

IV. The PISTILLUM, (a pestle). This is the female of the flower, proceeding from the pith of the plant; and is that erect column, which is generally placed in the centre of the

to this rule, not being alternate with the segments of the corolla, but opposite to them; which gives the essential character.-As soon as the stamina have performed the office assigned by nature, they wither and drop off. See note to callinsonia.

* The particles of the pollen or farina, appear by glasses to be of very different forms.-The pollen makes a third division of the stamen, but Linnaus generally includes it in the term anthera, along with the little cells in which it is enclosed. 
flower, amidst the stamina; and consists of three parts, the germen, the style, and the stigma.

The GERMEN (a bud) is the base of the pistillum, supporting the style, and, after a process of nature, becomes a seedvessel; may therefore be considered as the rudiment of the pericarpitum; and is distinguished by its shape, number, and situation; and is said to be above or below, aceording to its situation above or below the attachment of the corolla.

The STy LE (from stylus, a pillar) is that part which elevates the stigma from the germen, in order to receive the influence of the stamina, and to convey the effects down to the germen, as through a tube. It is distinguished either by its number,* which, when present, (or when absent, the number of stigmata) gives rise to most of the orders, and are called so many females; or by its divisions (laciniæ) being double, treble, or quadruple, \&c. though joined at the base; or by its length, being longer, shorter, or equal with the stamina; or by its proportion, being thicker or thinner than the stamina; or by its figure, being angular, cylindric, awl-shaped, bent, \&c.; or by its situation, being generally on the top of the germen, though in some instances supposed to be both above and below, as in capparis and euphorbia; unless the lower part in these genera be considered as the extension of the receptacle: It is also often placed on the side of the germen, as in hirtella, suriana, also in rosa, rubus, and the rest of the plants in the class and order icosandria, polygynia. With respect to duration, it generally falls with the other part of the flower; but in some plants is permanent, and attends the fruit to its maturity, as in the class tetradynamia. In flowers which have no style, the stigma adheres to the germen.

* The number of styles, generally speaking, is equal to the number of germina, each germen having its own proper style. The compound flowers, in the class syngenesia; the cone-bearing plants ; rose, ranunculus, and many others, shew this to be the natural structure: yet several plants have more than one style to a single germen, as in the umbelliferous plants (pentan. digyn.) and many others. Some have only one style common to many germens, as the rough-leaved plants (pentan. mono.) and most of the lip flowers (didyna. gymnos). Again, there are some plants which seem to form a medium between the two latter, the style being single at its base, but afterwards branching out into as many ramifications as there are divisions or cells in the seed-vessel, as in geranium, and mallow, also in hibis. cus, and some others. 
The STIG MA, (a mark) when single, is generally placed like a head on the summit of the style; when several, they are either placed on the top, or regularly disposed along the side; and covered with a moisture, to retain the pollen of the antheræ. It is distinguished either by its number, being single in most plants; by its divisions; by its figure or shape; by its length; by its thickness; and by its duration, as in most plants it withers when the germen is become a seed-vessel; in some it is permanent, as in papaver.

V. The PERICARPIUM (round the fruit) is the germen grown to maturity, and now become a matrix or seed-vessel; yet, however, all plants are not furnished with a seed-vessel, as in corylus, \&c. and in many it is supplied chiefly by the calyx, which converging, encloseth the seeds till they arrive at maturity; as is the case with the rough-leaved plants, the lip, and compound flowers of the several classes, pentandria, didynamia, and syngenesia: Sometimes the receptacle supplies the office of seed-vessel, as in gundelia; and sometimes the nectarium, as in carex. The pericarpium is situated at the receptacle of the flower, either above or below, or both, as in saxifraga and lobelia; and is distinguished by the following appellations, according to its different structure.

1st. Capsula, (a little chest or casket) which is frequently succulent whilst green, but when ripe, is a dry husky seedvessel, that cleaves or parts in some determinate manner, to discharge its contents; and by some sort of elastic motion, the seeds are often darted forth with considerable velocity, as in dictamnus, \&c. It opens also various ways, either at the top, as in most plants; at the bottom; at the side; horizontally across the middle, or longitudinally; and if it is articulated or jointed, it opens at each of the joints, which contains a single seed. It is further distinguished externally, by its number of valves; $*$ and internally, by the number of its cells or divisions, wherein the seed is enclosed; as also by its shape and substance.

* Capsules and dry pods are divided externally into one or more pieces, called by Linnæus valves; and internally are generally divided by membranous partitions (called dissepiments) into cells, sometimes longitudinally, as in cheiranthus, lu= naria, \&c.; and sometimes transversly, as in jointed pods. 
2d. Srligua (a pod) is a pericarpium of two valves; but as some are long, others round or broad, Linnaus thought it necessary to distinguish them by their form, into siliqua and silicula; which gives rise to the two orders in the class tetradynamia: The siliqua means a long pod, being much longer than broad, as in brassica, sinapis, \&c.; the siliculic (a little siliqua) is a roundish pod, either flat, or spherical, and the length and breadth nearly equal, as in lunaria, drabu, thlaspi, \&c. in both, the apex, which had been the style, is often so long beyond the valves, as to be of equal length with the pod; and the seeds in both are fastened alternately by a slender thread, to both the sutures or joining of the valves.

3d. LFGumen (pulse) is also a pod, and is likewise a pericarpium of two valves, wherein the seeds are fastened to short receptacles along the upper suture only, on each side alternate: This chiefly belongs to the papilinaceous (butterfly) flowers of the class diadelphia.

4th. Foluiculus ( a little bag, in former editions called conceptaculum) is a pericarpium of one valve only, opening lengthways on one side, and the seeds not fastened to the suture, but to a receptacle within the fruit, as in apocynum, asclepias, \&c.

5th. Drupa (from drupæ, unripe olives) is a pericarpium that is generally succulent, or pulpy, having no valve or external opening, and generally contains within its substance a stone or nut; $*$ that is, a seed enclosed with an hard ligneous crust, as olea, cornus, juglans, prunus, amygdalus, \&c.; and when the drupa is seated below the calyx, it is furnished with an umbilicus, like the pomum.

6th. Pomum (an apple) is also a pericarpium that is succulent or pulpy, and without valve; but containing in the middle a membranous capsule, with several cells or cavities,

* All drupes have not a stone or nut (properly so called) for the seed, as in schreberu, \&c. neither have all seerls that are called nuts a drupe for the pericarpium, as in fagus it is called a capsule, one-celled, four-valved, containing two nuts; in quercus, as also in corylus, and trapa, there is no pericarpium, the nuts are lodged in the calyx; and in pinus the nut is lodged in the calyx strobile; $1 n$ connabis the seed is also called a nut lodged in the calyx. See note to lacca. 
containing the seeds; and at the end opposite the footstalk, is generally a small cavity, called umbilicus, (the navel) from its resemblance to that part in animals, and which was formerly the calyx, seated above the fruit, and permanent, as in pyrus, cucumis, cucurbita, Sce.

17th. BACCA (a berry) is also generally a pulpy pericarpium without valve, enclosing one or more seeds, which have no membranous capsule, but are disposed promiscuously throngh the pulp without other covering, ${ }^{*}$ as in solamum, \&c. and are generally placed on footstalks, attached to receptacles within the pulp, as in ribes, \&c. 'The berry also admits of the following distinction; it is said to be proper, when it is a true pericarpium formed of a germen; and improper, when it is formed from other parts of the fructification; as in morus, rosa, juniper, taxus, \&c. a large succulent calyx becomes a berry; and in jumiper the three petals become the umbilicus; in poterium the berry is formed of the tube of the corolla; in fragaria, \&c. it is formed of the top of the receptacle; in rubus, \&c. it is formed from a seed, which is the receptacle of the berry ; in ruscus, \&c. it is enclosed within, and is a part of the nectary. The berry is commonly either round or oval, and is frequently furnished with an umbilicus, as in ribes, \&c: It doth not naturally open to disperse the seeds like the capsule, that office being performed by birds and other animals.

* Dr. Milne, in his Botanical Dictionary, thinks Linnæeus's definitions of the drupe and berry very imperfect; for the pericarpium in capsicum is called a berry, yet bath no pulp, and is hollow within; also in xanthizum it is called a berry, though it contains a nut in a dry pericarpium: neither is drupa always succulent or pulpy, though so defined, as in ulmus, pistacia, sparganium, \&c.; neither is the seed always a stone or nut, as in ulnus, schrebera, fugellaria, and mangifera.But in the later editions the pericarpium of ulmus is now altered to a berry, and that of xanthium to a drupe : and though the seeds in fiagellaria, \&c. are not properly nuts, yet they are large and single, and are generally called nuclei.-Linnæus is very nice and accurate in those plants which he hath seen himself, bur where he hath taken the description from others, or from dryed 'specimens, it is sometimes imperfect.-Though the drupe and berry are generally succulent, yet in some plants he describes them as dry; as in pistacia, \&c. the drupe is called dry; and in trientalis, \&c. the berry is called dry; for the chief ruling distinction is, that the capsule is divided into parts called valves, and the drupe and berry are entire, having no valve; and in favour of this distinction, he sometimes calls the dry drupe or berry, a capsular drupe or berry, from its resembling the capsule as to its dry. ness, but without valves. 
8th. STorilus* (a cone) is a pericarpium formed of the amentum, being a seed-ressel composed of woody scales placed against each other in the form of a cone, opening only at the top of the scales, being fimly fixed below to a sort of axis, or receptacle, occupying the middie of the cone, as in pimes, thuya, cupressus, \&c.

VI. The SEMINA, + (seeds). A seed is the essence of the fruit of every vegetable, and is defined by Linnaus to be a deciduous part of the plant, containing the rudiments of a new vegetable, fertilized by the sprinkling of the pollen; and they are distinguished according to number, shape, texture, appendage, \&c. A seed, properly so called, consists of the five following parts; to which is added the nut and propago.

* Though Linnæus calls strotilus a pericarpium, from its containing the seed; yet in his Gen. Pl. he rather makes use of it as a caly $x$ in many of the cone-bearing genera; which in his Fragments of a natural Method, under the order coniferce, amount to seven, (viz.) cupressus, ephedra, equisetum, juniperus, pinus, taxus, and thuya, to which may be added lanksia: In which, as the seeds are attached together in the form of a cone, so the plants themselves grow conically, and make a beautiful appearance; all of which are evergreen, (except the larch) resinous, warm, stimulating, and diuretic.

+ Plants, in analogy to animals, may properly be said to be viviparous and oviparous; seeds are vegetable eggs, and buds the living fœetusses, or infant plants ; some also are only viviparous, others only oviparous.-The focundity of some plants is wonderful. Dr. Milne says, from a single plant or stalk of Indian Turkey wheat, are produced in one summer, 2000 seeds; in clecampane, 3000 ; of sunfiouer, 4000 ; of poppy, 32000 ; of a spike of cat's tail, 10000 and upwards; a single fruit or seed vessel of tobarco contains 1000 seeds, that of white poppy 8000. Mr. Ray relates from experiments, that 1012 tobacco seeds are equal to one grane, and consequently those of the whole plant, in that proportion, amounted to 360000 : he also estimates the annual produce of a single stalk of spleen-wiort to be upwards of one million of seeds.

Reproduction is perhaps one of the greatest curiosities in the animal system; if a Crab or Lobster loses a leg, another will be reproduced; a species of Earth-worm may be cut in two, and each part will become a perfect worm; and the Polype (an aquatic insect) as also the Hirudo-viridis (the English green-leech) may be cut into a thousand pieces, and each part will become a perfect animal.-So in the vegetable system, M. Reynier, by depriving flowers of the sexual organs, hath discovered in many instances an attempt to reproduce the stamina and pistilla, for the flower threw out filaments from the wounded parts of different lengths, as was very apparent in the echinops ritro, geum rivale, and in many of the mallows: but it doth not appear from his experiments that antheræ were reproduced, yet he mentions that some of the flowers bore seeds. Royal Academy of Sciences, Paris, 1786. 
1st. The Corculum (from cor, a heart) is the essence of the seed, and principle of the future plant; and consists of two parts, (viz.) plumula and rostellum. Plumula (a little feather) is the scaly part and essence of the corculum, which ascends and becomes the stem or trunk of the plant: it extends itself into the cavity of the lobes or cotyledons, and is terminated by a small sort of branch resembling a feather.Rostellum (a little beak) is the plain or simple part of the corculum, which descends into the earth, and becomes the root: its form is that of a small beak, placed without the lobes, and adhering internally to the plumula.

2d. The Cotyledons (from cotyledon, the hollow of the hucklebone) are the thick porous side-lobes of the seed, consisting of farinaceous matter, and which involve, and for some time furnish nourishment to the embryo plant; but when it becomes strong, they wither and die away."* The cotyledons are also called the seminal or seed-leaves; some plants have only one, $\uparrow$ as in grasses and in cuscuta, \&c.; others two, as in vicia, \&c.; linum hath four ; cypressus hath five; and pinus, Linnæus saith, hath ten. The cotyledons in mushrooms, ferns, and mosses, are not sufficiently ascertained, to know if they have any.

3d. The Hicum (the black spot on a bean, called the eye) is the external mark or scar on the seed, where it was fastened within the pericarpium.

4th. The Arjluus, a term used by Linnæus, to express the proper exterior coat or covering of the seed; which falls off spontaneously, and is either cartilaginous or succulent;

* If a plant be cut below the cotyledons, it will scarce ever put out fresh leaves, but withers and decays; if it is cut above the cotyledons, it generally shoots out afresh, and continues to grow : Therefore, if plants, whose cotyledons rise above ground, as turneps, leans, peas, \&c. be cut, or eat to the ground by cattle, they decay; but where the cotyledons remain below ground, as in grasses, and are cut or eat to the ground, they will shoot out afresh.

+ Linnæus observes that those plants which are said to have only one cotyledon, may more properly be said to want them, as they remain within the seed; as such seed doth not split when it germinates, but continues entire, to nourish the infant plant.-Two cotyledons are most common, and those plants that are thought to have more, are in fact said to be only different divisions almost to the base. 
yet seeds are said to be naked, when not enclosed in any sort of pericarpium, as in the class and order didynamia gymnospermia.

5th. The Cononula, (a little crown) which is either a little sort of calyx, (caliculous) adhering to the top of the seed, like a little crown, and assisting to disperse it by Hying, as in scabiosa, knautia, \&c. where the little calyx of the foret becomes the crown of the seed. Or the coronula is a down* (pappus) which is either feathery, as in valeriana, leontodon, gnaphalium, \&c. or it is hairy, as in tussilago, senecio, hiercicium, \&c.; it is also either sitting, (sessilis) that is, attached close to the seed, as in hieracium, \&c. or footstalked (stipitatus, from stipes) by a thread, elevating and connecting the crown or tuft with the seed, as in lactuca, crepis, \&c. Some seeds are also furnished with a wing, a tail, a hook, an awn, \&c. all coming under the term coronula, and tending either to disperse or fix the several seeds to which they belong.

6th. Nux, (a nut) which is a seed enclosed in an hard woody substance, called the shell, which is one-celled, two-celled, \&c. and the enclosed seed is called (nucleus) the kernel.

The seed of a moss, not coming under the above description, Linnæus calls Propago, (a slip or shoot) which hath neither coat nor cotyledon, but consists only of a naked plumula, where the rostellum is inserted into the calyx of the plant.

VII. The RECEPTACULUM (receptacle) is the base which receives, supports, and connects the other parts of the

* The down with which many seeds are furnished, as in goat's-leard, dandelion, thistle, \&c. hath generally been thought intended to disperse them: yet as the down frequently breaks off, and is seen flying alone; it hath been imagined by some, that the down is only intended as a defence of the seed till arrived at maturity. Some seeds are also furnished with an elastic force, in order to disperse them, which is either in the calyx as in oats, and some others; in the pappus, as in centaurea-crupini; or in the capsule, as in justicia, geranium, fraxinella, spurting cucumber, liura, \&c. Other plants of the burr kind, as lurdock, hairiff, \&c. are furnished with little hooks to stick to the hair of animals, by which means the seeds are dispersed. Other seeds, especially those whose pericarpium is a berry, as also the nutmeg, and other nuts, are dispersed by birds and other animals.

See note to momordica elaterium. 
fructification, but it is only mentioned by Linnæus (in his Gen. $P l$.) when it can be introduced as a character varying in shape and surface, as principally in the class syngenesia. It hath the following distinctions:

1st. A PROPER RECEPTACLE, when it supports the parts of a single fructification only; and when it is a base to which only the parts of the flower are joined, and not the germen, it is called a receptacle of the flower ; in which case, the germen being placed below the receptacle of the flower, hath a proper base of its own, which is called the receptacle of the fruit; and it is called a receptacle of the seeds, when it is a base to which the seeds are fastened within the pericarpium. (see bacca); in some simple flowers, where the germen is placed above the receptacle of the flower, the fruit hath a separate receptacle, as in magnolia, uvaria, \&c. in which genera the numerous germens are seated upon a receptacle, rising like a pillar above the receptacle of the fructification.

2d. A common Receptacle, called so because it supports and connects a head of flowers in common, as in the amentum, and other aggregate flovers.

3d. Umbella, (an umbel) which Linnæus calls a receptacle.-See aggregate flowers.

4th. Cума (a sprout) is also called a receptacle.-See aggregate flowers.

5th. RAchis, (the back bone) a thread-form receptacle, collecting the florets longitudinally into a spike, in many of the glumose flowers, as wheat, barley, rye, \&c.

6th. Spadix (a branch of the palm) antiently only signified the receptacle of a palm, issuing out of a spatha, and branched: but now every flower stalk that is protruded from a calyx called spatha, is called a spadix, as in narcissus, \&c.see aggregate flowcrs. 


\title{
A SPECIMEN
}

OF THE

\section{DESCRIPTION OF A PLAN'I,}

According to the Generic Character, from the Genera Plantarum; and also the Essential Character of the same Plant, with the several Species, from the Systema Vegetabilium.

\author{
PAPAVER. \\ (POPPY.)
}

Generic or Natural Character.

CAlxx. A perianth, two-leaved, ${ }^{*}$ egged, end-nicked; the leaflets rather egged, concave, obtuse, deciduous.

Corolla. Petals four, roundish, flat, expanding, large, narrow at the base, less alternately.

Stamina. Filaments numerous, capillary much shorter than the corolla; anthers oblong, compressed, erect, obtuse.

Pistillum. Germen, roundish, large; style none; stigma targetted, flat, radiated.

Pericarpium. A capsule crowned with the large flat stigma, one cell, half-many-celled, gaping at the top under the crown with many apertures.

Semina. Seeds numerous, very small; receptacles, longitudinal folds, of equal number with the rays of the stigma. adhering to the sides of the pericarpium.

* The two leaves of the calyx fall off when the flower opens. 


\section{Essential Character.}

PAPAVER. Corolla four-petaled; calyx two-leaved; capsule one-celled, gaping with pores under the permanent stigma.

Poppy.

* With hispid capsules.

1 P. Iyeridum. Capsules subglobular, brawny, hispid, stem leafy, many-flowered.

Mule.

2 P. Argenone. Capsules clubbed, hispid, stem leafy, many-flowered. Kough Poppy.

3 P. Alpinum. Capsules hispid, scape one-flowered, naked, hispid, leaves twice feathered.

Alpine.

4. P. Nubicaule. Capsules hispid, scape one-flowered, naked, hispid, leaves simple, feather-sinuous. Naked Stem.

* With smooth cupsules.

5 P. Rhozas. Capsules smooth, globular, stem hairy, many-flowered, leaves feather-cleft, gashed.

Red Field Poppy.

6 P. Dubium. Capsules oblong, smooth, stem many-flowered, with bristles appressed, leaves feather-cleft, gashed.

Dubious.

7 P. Somniferum. Calyxes and capsules smooth, leaves stem-clasping, gashed.

Somniferous.

8 P. Cambricum. Capsules smooth, oblong, stem manyflowered, polished, leaves feathered, gashed.

Welch.

9 P. Orientali. Capsules smooth, stem one-flowered, rugged, leafy, leaves feathered, sawed.

Oriental.

N.B. The papaver cambricum, and the papaver orientale are both perennial; the papaver nudicaule is biennial; and the others are annual.-Papaver nudicaule hath two varieties, distinguished by the colour of the flower; and the papaver somniferum hath three varieties, distinguished by the colour of the seed. 


\title{
THE DISTINCTION OR MODE OF FLOWERING:
}

\author{
CALLED
}

\section{THE INFLORESCENCE。*}

Complete frowerst are either simple or aggregate; simple, when no part of the fructification is common to many flowers or florets, but is confined to one only; aggregate, when the flower consists of miany florets collected into a head by means of some part of the fructification common to them all, as by a common receptacle, or common calyx; as in dipsacus, scabiosa, \&c.

From the different structure, disposition, and other circumstances of the receptacle or calyx, being the only common part to aggregate flowers, arise seven divisions.

1st. AgGREGATE, properly so called, consisting of such flowers as are formed by the union of several lesser flowers of florets, placed on partial peduncles, $\ddagger$ on a common dilated

* This term is defined to be the mode by which flowers are joined to their several peduncles, whether common or partial.

+ A flower in the Sexual Botany hath a very different signification from the same term of former writers; for if the antheræ and stigma be present; though the calyx, corolla, filaments of the stamina, and style of the pistillum be wanting; it is still a flower; and if all the parts are present, it is a complete flower. The seed also constitutes the fruit, whether there be a pericarpium or not.-The different colours and odours of plants and flowers are supposed to proceed, by a chemical process of nature, from the different qualities of the juices of plants combined with their essential oils. In many plants the colour of the flower corresponds with the juices of the root, as in eelandine, larbary, \&c. and in these plants the colour is more fixed, and apt for dying.

${ }_{\rightarrow}$ A peduncle is the footstalk of a flower only, issuing from the branches: the footstalk of a leaf is called petiole: peduncles are called fastigiate, when there are several, and their lengths so proportioned, that the flowers form a regular surface. The whole flower of the aggregate sort is called flos universalis, and the partial florets are called flores proprii; and each floret, in some genera, is a complete fructification of itself, having calyx, corolla, \&c. 
receptacle,* and within a common perianthium; and in those flowers where each floret hath its proper calyx, that is also a perianthium.

2d. CoMpOUND AGGRGATE, consisting also of several lesser Howers or florets, placed sitting (or without partial peduncles) on a common dilated receptacle, and within a common perianthium; and where each floret hath its proper calyx, it is also a perianthium. Compound flowers also admit of a further description, (viz.) each floret consists of a single petal, with generally five divisions, and having five stamina distinct at the base, but united at the top by the antheræ into a cylinder, through which passeth the style of the pistillum, longer than the stamina, and crowned by a stigma with two divisions, that are rolled backwards, and having a single seed placed upon the receptacle under each Horet.

This is the general character of a regular compound fower, to whrch there are a few exceptions; it also differs when the flower is radiate; + but the essential character of a regular floret consists in the antheræ being united so as to form a cylinder, and having a single seed placed upon the receptacle ander each floret.

3d. UMBELLATE AGGREGATF, when the flower consists of many florets placed on fastigiate peduncles proceeding from the same centre or receptacle, rind though of different lengths, rise to such an hight, as to form a regular head or umbel, whether Hat, convex, or concave; and both the common and partial calyx, Linnæus calls an involucrum. $\neq$ It is

\footnotetext{
* The membranous sort of chaffy substance, or laminæ, frequently growing on the receptacle, and intended as a partition between the florets, is called palea (chaff.)

+ A flower is said to be radiate, when the florets in the radius or circumferencediffer from those in the disk; in which case they are generally larger, and are called sem $i$-florets, from their difference in form, and in distinction from those of the disk, which are called proper-florets : and they also differ as to ser, as in dancus, \&c. which gives rise to several of the orders in the class syngenesia, which contains the compound flowers; and where they are further explained.
}

¥ The involucrum in umbellate flowers, greatly differs as to the number of leaves; and generally each floret hath a proper perianthium, besides the two invo. ducres. 
called a simple umbel, when it hath no lesser divisions; a compound umbel when each peduncle is subdivided at its extremity into many lesser peduncles for supporting the flowers, so as to form several little umbellas, uniting in one head; the whole together is called an universal umbel, and the little umbellas are called partial umbels. (See the class pentandria, order digynia). In some gencra, that have radiated flowers, the florets of the centre and those of the circumference, differ both as to sex and size; but in general each hath five petals, five stamina, and two styles, or one that is bifid (two-cleft), with a germen placed beneath, and two naked seeds, which when ripe, separate below, but remain connected at the top.

4th. Cymous agGRegate, (from cyma, a sprout) called by Linnæus a receptacle, is when several fastigiate peduncles proceed from the same centre, like the umbel, and rise to nearly an even hight; but unlike the umbel, the secondary or partial peduncles proceed without any regular order, ${ }^{*}$ as in sambucus, viburnum, \&c.

5th. AMENTACEOUS AGGREGATE, are such flowers as have a long common receptacle, along which are disposed squamæ or scales, which form that sort of calyx called an amentum or catkin, as in corylus, pinus, juglans, \&c. Amentaceous flowers generally want the petals, and all of them are of the classes monoecia and dioecia.

6th. GLumous AGgREGTE, are such flowers as proceed from a common husky calyx belonging to grasses, called glu$m a$; (see class trian. digyn.) many of which are placed on a common receptacle called rachis, collecting the florets into the spike, as triticum, hordeum, secale, lolium, \&c.

7 th. SPADICEOUS AGgREgate, are also such flowers as have a common receptacle, protruded from within a common calyx, called spatha, along which are disposed several florets; such a receptacle is called a spadix, and is either branched, as in phanix, or simple, as in narcissus, \&c.: In this last case

* Cymous flowers have no common calyx, yet each floret hath a perianthium (generally very small) either above or below the germen. In sambucus, and vilurnum it is placed above. 
the florets may be disposed, either all around it, as in calla, dracontium, pothos, \&c.; on the lower side of it, as in arum, \&c.; or on two sides as in zostera, \&c. These flowers have generally no partial calyx.

These are the several distinctions of aggregate flowers, (according to Linnæus); besides which there are several other modes of flowering, properly so called, which come under the general term INFLORESCENCE; and often afford the best marks to discriminate the species. These modes of flowering are chiefly expressed as follow:

Ist. VERTICILLUS, (a verticil, or whirl) when the flowers are placed in whirls at each joint, round the common stalk $; \uparrow$ they have very short partial peduncles, are all of the lip kind, and have either two or four stamina, and four naked seeds, as in salvia, marrubium, mentha, \&c. A verticil hath several distinctions, as naked, bracted, \&c.; and all those genera with four stamina, are of the class didynamia.

2d. Capitulum, (a little head) when many flowers are connected into nearly a globular form or head, on the summit of the common stalk, sometimes with, and sometimes without partial peduncles, as in gomphrena, \&c. and is distinguished by its shape, and other circumstances. Under capitulum is now introduced the term FAscicuLUs, (a little bundle) which in former editions stood distinct. It means when the peduncles are erect, parallel, approaching each other, and raised to the same hight, as in dianthus-barbatus, (sweet william)

* The leaves of verticiled planis are fragrant, warm, and aromatic. *

+ Common receptacles and common peduncles we must take from Linnæus; he only calls those common receptacles, that belong to aggregate flowers. Proper modes of flowering are said to be either sitting, or on common or partial peduncles; and to constizute an aggregate flower, the common receptacle must either be dilated, as in the first two distinctions; or it must be a centre from whence the peduncles proceed, as in the umbel and cyme; or it must proceed from, or be connected with a common calyx, as in the other distinctions. Some of the species under the modes of flowering on peduncles, are also aggregate flowers, as being within a common calyx, as oats, panic-grass, \&c. under panicula; and some of the species of dianthus, under the first distinction, are called aggregate, though fascicled and headed.-Pediculus (a pedicle from pes) was used by the antient botanists for the footstalk of a leaf or flower; but Linnæus has exploded the term, and substituted petiolus for the footstalk of a leaf, and pedunculus for that of a flower. 
where they generally proceed from different parts of the common stalk, opposite to each other.

3d. Sprca, (a spike) when the flowers, having no partial peduncles, are arranged alternately around a common simple peduncle; and it is called spica secunda, (a single rowed spike) when the flowers are all turned one way, following each other; and spica disticha, (a double rowed spike) when the flowers stand pointing two ways, as in lolium, \&c.: and it is distinguished by shape and other circümstances.

4th. Corymbus, (a cluster of ivy berries) when the lesser peduncles of the flowers proceed from different parts of the common peduncle or stalk; and though of unequal lengths, and sometimes simple, and sometimes branched, yet form a regular surface at the top; as in the siliquose plants (class tetradynamia). The corymbus may be supposed to be formed from a spike, by adding partial peduncles to the flowers; and seems to be the mean between racemus and umbella, the peduncles rising gradually from different parts of the common stalk, like those of the raceme, and proceed to a proportionable hight like those of the umbel.

5th. ThYrsvs (a young stalk). A thyrse is a mode of flowering resembling the cone of a pine : Linnæus saith, it is a panicle contracted into an oval, or egg-shaped form; the lower peduncles, which are longer, extend horizontally; and the upper, which are shorter, mount vertically, as syring a, \&c.

6th. RACEMUS, (a bunch of grapes) it is called a raceme, when the flowers are placed on short partial peduncles, proceeding as little latteral branches from and along the common peduncle; it resembles a spike in having the flowers placed along a common peduncle, but differs from it in having partial peduncles; it also differs from a corymbus in the shortness and equal length of its peduncles, not forming a regular surface at the top; as in ribes-rubrum, vitis, \&c.

7 th. Panicula, (the tuft upon reeds, a panicle) when the flowers are dispersed upon perluncles variously subdivided; or it is a sort of branching spike, composed of several smaller spikes, attached along a common peduncle, as in avena, panicum, and several ofher grasses, and many other planto. 
Wher the partial peduncles diverge and hang loose, it is called a diffuse, and when they converge, it is called a close panicle.

To these may be added the term Axiluiares, (from axilla, the arm-pit) being such flowers as proceed from the angle formed by the leaf and the stem, as is most common: And Terminales, being such flowers as terminate the stalk or branch. Also every other mode of flowering is called the Inflorescence, whether opposite the leaves, lateral, single, double, erect, bending; \&c.

Under this head of Inflorescence may be explained LuxuRIANT FLOWERS, (commonly called double flowers) which, as they are considered only as varieties and unnatural, belong properly to the head, Habit of plants. A luxuriant flower is supposed generally to be owing to superabundant nourishment; the luxuriant part is generally the corolla, but sometimes the calyx also. It is divided into three degrees; 1 st. multiplicatus, $2 \mathrm{~d}$. plenus, $3 \mathrm{~d}$. prolifer. To which may be added, as an opposite imperfection, flos mutilatus.

1st. Multiplicatus, (multiplied) when the petals of the corolla are orly so far multiplied, as to exclude part of the stamina; and it is called duplicate, triplicate, quadruplicate, ixc. according to the number of rows of petals.

2d. Plenus, (full) when the corolla is so much multiplied, as to exclude all the stamina ; which is occasioned by the stamina running into petals; and the flower is often so crowded, as to exclude or choke the pistillum also. Therefore, as the essential parts of generation are thus wholly, or in part destroyed, the plants become barren or imperfect, and no seed, or very little, can be expected from them.* Flowers with one petal are not very subject to fulness, when they are, it generally arises from an increase of the divisions of the petal. It is most usual in Howers of many petals, where it arises various ways; sometimes by multiplication of petals only, sometimes of the calyx or nectarium, and sometimes of all. Compound flowers are also suject to luxuriance, arising several ways.

* A remarkable instance of plenitude is in the gelder rose (viburnum opulus torepleno) where all the flowers are barren.

E 
3d. Prolifer, (prolific) when one flower grows out of another; this generally happens in full flowers, from their greater luxuriancy; in simple flowers, it rises from the centre, and proceeds from the pistillum shooting up into another flower, standing on a single footstalk. In aggregate flowers (properly so called) many foot-stalked flowers are produced out of one common calyx. In umbellate flowers, a second umbel proceeds from the centre of the first umbel, producing little umbels; which by a greater exertion of luxuriancy may produce others with little umbels, and thus may proceed several heads of flowers, each growing out of that immediately below it, furnished with little umbels variously compounded. A prolific flower is also called leafy, (frondosus) when it produceth branches with flowers and leaves, which, though rare, sometimes happens in rosa, anemone, monarda, and others.*

Flos mutritatus, (a mutilated or maimed flower) is such a flower as occasionally is deprived of all, or the greatest part of the petals, yet bears seeds, as in some species of tussilago, campanula, \&c. This term is opposed to luxuriance, and is supposed by Linnæus to be caused by a defect of heat, though it may also happen by other causes.

Under this head of flowers, may also be mentioned the different sexes.

FLow ERs, in respect to SEX, are distinguished into male, female, monoclinian, and neuter. Male flowers are such as have only the stamina or males, as in the classes monoecia, dioecia, and polygamia. Female flowers are such as have only the pistilla or fermales, as in the same classes monoecia, dioecia, and polygamia. Monoclinian Howers are such as have both the stamina and pistilla in the same bed or flower, as in all the other classes: monoclinians are also distinguished into

* As in luxuriant flowers many parts of the natural character are deficient is the whole or in part, they can only be distinguished by the general habit, and by such parts as remain in the natural state; as very often by the calyx, and in polypetalous flowers, the lowest series or rows of petals remain the same, as in rosa, papaver, nigella, \&c.

All double flowers, though admired by the florists, are termed by the botanist vegetable monsters. 
male monoclinians, when the female is ineffectual; and female monoclinians, when the male is ineffectual. Neuter flowers are such as have neither stamina nor pistilla perfect; see the class syngenesia. The plants themselves also take a denomination from the sex of their flowers; as male plants are such as bear male flowers only; female plants are such as bear female flowers only; monoclinian plants are such as bear monoclinian flowers only. Androgymus (male and female) plants are such as bear both male and female flowers, distinct, upon the same root, as in the class monoecia. Polygamous plants are such as bear monoclinian flowers, and male or female flowers, or both distinct, on the same or on different roots: if on-the same root, the flowers are either male monoclinians and female monoclinians; or monoclinians and male; or monoclinians and female, distinct: if on different roots, the flowers are either monoclinians and male; monoclinians and female; monoclinians and both male and female; or are androgynus. and male; and sometimes androgynus and male and female on three distinct plants.-See the class polygamia.- See also the class syngenesia, where polygamy gives rise to the orders of the compound flowers. 


\section{THE PRINCIPAL}

\section{OUTLINES OF A PLANT.}

A PLANT principally consists of root, trunk, leaves, props, fructification, and inflorescence; and also the habit.

I. The ROOT consists of two parts, (viz.) the caudex and the radicula, distinguished according to shape, direction, duration, \&c.

CaUdeX (a stump) is the body or knob of the root, from which the trunk and branches ascend, and the fibrous roots. descend; and in different plants is either solid, bulbous, (placed under a bulb, as in tulips, \&c. or above the bulb, as in orchis, \&c.) or tuberous. Solid, as in trees, shrubs, and many of the herbs. Bulbous will be explained under hybernacle. Tuberous knobs* are also solid and hard, containing one or more embryos or eyes; and are either only one knob, as turnep, carrot, \&c. containing only one eye at the top; or consist of many knobs connected together by slender fibres, as in potatoes, jerusalem artichokes, \&c, each containing many eyes dispersed over the surface; and are either pitted, when the eyes lie inward, as in potatoes, \&c.; or tuberculed, containing the eyes outward, as in jerusalem artichokes, \&c. In tuberous knobs, the fibres or stringy parts issue from different

* Those tuberous knobs with only one eye, differ as to duration, but are in general biennial; those with many eyes are perennial; both seem to be produced by the nutriment of the stem, and not by the fibrous roots, for the stem is first formed and becomes strong, and as it grows to maturity, the tuberous knobs increase; or as it is said in Phytologia, not until after the leaves are expanded in the air to oxygenate the vegetable blood. It is also said that pinching off the flowers of the potatoes, will increase the size and quantity of the roots, by adding to the roots the nourishment required for the flowers and seeds.-Tuberous roots are increased in number by a seminal chord which proceeds under ground from the old root, after the leaves are expanded; in the same manner as the wires of strawberries, which may be called seminal chords above ground, and the design seems evidently to place the offspring at a convenient distance trom the parent plant, that they may not incommorle each other.

Phytologia. 
parts of the surface, which is an essential difference from bulbous knobs, where they are confined to the caudex of the bulb only, and are the true and genuine roots; the bulb itself being only a large bud under ground.

RA DICULA (a little root) is the stringy or fibrous part of the root, descending from the candex; and is really the principal and essential part of every root, and by which the nourishment is drawn from the earth for the support of the plant.

II. The TRUNK, which includes the branches, is that part. which rises immediately from the caudex, and produceth the leaves, flowers, and fruit. It is either herbaceous, shrubby, or arborescent; and is generally covered with an outer and an inner bark;* and is distinguished according to its shape, substance, surface, \&c. and admits of the following sorts, (viz.) caulis, culmus, scapus, stipes.

1st. Caulis (a stalk or stem) is the main or universal trunk, which elevates the leaves, and fructification, and is applied to trees, shrubs, and herbs: It is either simple or compound; simple, when it doth not divide; compound, when it is divided into branches.

2d. Cunmus (a straw or haulm) is the proper trunk of grasses; and also elevates both the leaves and fructification: It is sometimes jointed, and sometimes not; it is also somekimes round, and sometimes angular. - See the class and order triandria digynia.

* The outer bark either runs longitudinally, as in $o a k, a s h$, \&c. and in most other trees; or transversely, as in cherry, birch, \&c. if transverse bark is put into the fire, it shrivels up, and burns like parchment or leather; but in those trees where the outer bark runs transversely, the inner, or principal bark runs longitudinally; several other trees than above mentioned have a transverse cuticle, but in a less perfect manner.-Many trees have what is called the sap (alburnum) which lies between the more solid woody part and the bark, as oak, fir, \&c.; and the sap juice is said to answer the same purpose to vegetables, as the chyle to animals; affording nourishment by sanguification and secretion; and in those trees that have not an apparent alburnum, as ash, \&c.; the inner bark, though less indurated, is supposed to answer the same purpose, as it contains much mucilaginous of nutritious matter. Phytologia, p. $492-187$. 
3d. Scapus (a stalk) is an herbaceous trunk, which elevates the fructification, but not the leaves; that is, it is a stalk proceeding immediately from the root, and terminated by the flowers, as in narcissus, hyacinth, \&c.

4th. STipes (a trunk) used by Linnæus for the trunk of mushrooms; as also for that slender thread or footstalk which elevates the feathery or hairy down, with which some seeds are furnished, and connects it with the seed, as in lettuce, dandelion, \&c.

III. The LEAVES, which are said by Linnæus to be the muscles or organs of motion of a plant; by others, the organs by which perspiration and inspiration are performed. Hence, like insects, if the spiracula of the leaves are stopped by covering the upper surface with oil, death ensues. They are defined as proceeding from the expansion of the vessels of the stalk, forming several ramifications like net-work, extended in length and breadth in a determinate manner, having the interstices filled up with a tender pulpy substance, called the parenchyma; and the external covering is supposed to be a continuation of the scarf skin of the stalk.

Leaves are either simple or compound, and are distinguished by their figure, situation, insertion, number, divisions, \&c.

A SIMPLE LEAF, is such as either adheres to the branch singly, or whose footstalk is terminated by a single simple expansion, not parted to the middle rib; and is determined by its shape, surface, and divisions.

A Compound LEAF, is such whose footstalk is furnished with several separate simple expansions, or in other words, whose divisions extend to the middle rib; now called a common petiole (or footstalk) supporting several lobes, or little simple leaves, of which the compound leaf consists; and are distinguished by shape, \&c. and the form by which they are attached to the common footstalk, as palmated, winged, feathered, \&c. Sometimes leaves are twice or more compounded, which divsions admit of many modifications, and give rise to as great variety of terms. It may sometimes be 
difficult, at first sight, to know a common footstalk to a compound leaf, from a branch; but it may be observed that a common footstalk, where it issues from the branch, is either flat or hollow on one side, and convex on the other; whereas branches are alike on both sides, whether round, flat, or angular: again, buds are never found at the angles formed by the lobes of a compound leaf with the footstalk; but at the angles formed by the footstalk of the whole compound leaf and the stem.* And it may always certainly be distinguished by its falling off with the little leaves which it supports.

The manner or place in which leaves are attached to the plant, is called the determination of leaves; and is as follows, distinguished by several terms, according to number, disposition, insertion, figure, \&c.

RADICAL OR ROOT LEAF, such as proceed from the root.

STEM LEAF, such as grow on the stem.

BRANCH LEAF, such as grow on the branches.

Axillary leaf, (from axilla, the arm pit) such leaves as grow in the angle formed at the insertion of the branch with the stem.

Flora L LEAF, $†$ (florale) such as are placed nearest to, and at the coming out of the flower; (see bractea, page 33). There are also seminul or seed-leaves, such as are first the cotyledons, and afterwards become leaves; but these are not noticed under determination of leaves, as not coming under the definition of a leaf.

* The flowers in fruit trees generally appear before the leaves, that the process of impregnation may not be interrupted.

+ Floral leaves are in general those leaves placed nearest to the flower, and when like the other leaves, they come under the definition of a leaf; but when they differ in size, shape, or colour, from the other leaves of the plant, they are called bractea, and come under the term fulcra, and often afford essential marks for distinction of species. 
IV. The PROPS, (fulcra) a term used to express those external parts which strengthen, support, or defend the plants on which they are found, or serve to facilitate some necessary secretion; and are as follow:

1st. Petiolug, the footstalk or support of a leaf.

2d. Peduncertus, the footstalk or support of a flower.

3d. Striptra, (haulm or husk) a sort of scale or small leaf, stationed in most plants (when present) on each side the base of the footstalk of leaves and flowers, at their first appearance, for the purpose of support: They are placed either single or double, and sometimes on the inside, tis in the fig and mulberry; or on the outside, as in the birth, lime, and papilionaceous flowers: They are also either sitting, extended downwards, or sheathing along the stem, as in the plane tree. As to duration, they sometimes fall before the leaves, and sometimes are equally permanent: They often afford a good distinction for the species.

4th. Crarus, (a curl) meaning a clasper** or tendril; being the fine spiral string or tibre, by which plants fasten themselves to some other body for support: They are sometimes placed opposite the leaves, sometimes at the side of the footstalks of the leaves, and sometimes issue from the leaves themselves; and sometimes they put out roots, as in $i v y, \& x$.

5th. Pubes, (hair or down) a term to express the hair, down, wool, beard, bristles, glands, and several other appearances, on different parts of plants, serving the double purpose of defence and vessels of secretion.

6th. Arma, (arms) the defensive weapons of plants; which are either spina, (a thorn) protruded firom the wood of the plant; aculeus, (a prickle) proceeding fiom the cortex or

* Plants that support themselves by claspers, catch hold of any thing in their way for that purpose; and are different from the twining plants, which support themselves by the twisting of the stalk, though both may be called climbing plants. - See explanation to ciass Diadelphia. 
suter bark of the plant, which are sometimes forked or divided, consisting of two or more prongs or divisions; or stimuli, (stings) producing inflamatory itching punctures to the naked parts of animals, by their venomous points.

7th. Bractex, (thin plates of metal) are sometimes called floral leaves, (floralia folia) when situated near the flowers, but differ in size, shape, or colour, from the other leaves of the plant; as in tilia, monarda, \&c.; and mean not only those leaves generally situated on the stalk nearest to the lower parts of the flower, but-are sometimes placed on the stalk at a distance from the flower, as in viola, and they sometimes seem to terminate the flower-stalk; being composed of a large tuft of leaves, resembling a bush of hair, (coma) and are then called bractece comose, as in crown-imperial,* lavender, and some species of sage.-See bractece under calyx.

V. The FRUCTIFICATION, or mode of fruit-bearing; consisting of the calyx, corolla, stamina, pistillum, pericarpium, semina, and receptaculum; all which have been already explained.

VI. The INFLORESCENCE, which is defined to be the mode by which flowers are joined to their several peduncles, whether common or partial; as hath been already explained.

VII. The HABIT of plants, by which antient botanists meant the whole external appearance of every part thereof, whereby they were arranged in their several systems; but by Linnæus it is meant to be the agreement of plants of the same genus or natural order; chiefly in the following circumstances:

Gemmation. The structure and disposition of the bulb, as solid, coated, scaly, stem-bulb. Also of the bud, its origin petioled, stipuled, cortical; its contents leafy, floral, common.-See hybernacle.

* The tuft of the crown-imperial (fritillaria imperialis) seems to terminate the flower-stalk, from the flowers hanging down; but when the flower decays, the germen swells to a large hexagonal capsule, filled with flat seeds, and becomes erect, above the tuft; the better to retain and disperse the seed.

See note to dodecatheon meadia. 
VERATION. The complication of the leaves within the bud, at spring, as conduplicate, convolute, involute, revolute, imbricated, equitant, obvolute, plaited, spiral.**

Estrvation. The state of the bud in summer, before the unfolding of the flowers, as convolute, imbricated, conduplicate, valved, unequal-valved.

Tortion. The twisting or bending of the parts, as uniform, dissimilar, from the right, from the left, reciprocal, resupine, spiral.

Nuptia ls. Male, female, androgynous, monoclinian.

Semination. The shape and other circumstances of the seed, as tail, wing, tuft, awn, hooks, gluten, curvature. Also of the pericarpium, as berrying, inflation, viscosity, elasticity, structure.

Placentation. The number and disposition of the cotyledons ; or if wanting.

Variation. Of colour, size, pubescence, age.

External. Plaited, bundled, broad-leaved, curled, awnless.

Internal. Mutilated, great-flowered, luxuriant, crested; viviperous, bulb-bearing.

By variation, or variety, are meant such differences as are only incidental to vegetables, and are not found constant and unchangeable; that is, where plants raised from the same seed, by some accidental cause, differ in form and appearance from

* Conduplicate, (doubled together) as in oak, hazel, walnut, \&c.

Convolute,.... (rolled together) as in bean, saxifrage, $\& \mathrm{c}$.

Involute, .... (rolled in) as in apple, pear, \&c.

Revolute, .... (rolled back) as in primrose, groundsel, colt's-foot, \&c.

Imbricated, .. (tiled) as in lilac, campanula, \&c.

Equitant, .... (riding) when the opposite margins approach, so as one to include the other, as in iris, sweet-rush, \&c.

Obvolute, .... (rolled against each other) as in pink, lychnis, teazel, \&c.

Plaited, ...... (folded over) as in leech, vine, currant, \&c.

Spiral, ....... (coiled like a. watch spring, one end in the centre) as in fern: 
the true character of the species to which they belong; which cause being removed, the plant is restored to its true specific character: and these incidental varieties chiefly arise by difference of soil or culture, in some of the above circumstances.

And though it is as necessary to collect varieties under their proper species, as the species under their proper genera; yet it is often more difficult; first, from the difficulty of ascertaining the genus, and secondly, from the variety confounding the species; ${ }^{*}$ and sometimes some parts of the specific character itself are also subject to variety, particularly the leaves; $\uparrow$ though in general the true specific character is constant and unchangeable, arising ouly from such circumstances wherein plants of the same genus are found to disagree, which distinctions are commonly taken with most certainty, from the following parts, (viz.) root, trunk, leaves, fulcra, hybernacle, inflorescence: all which parts have been already explained, except hybernacle.

The HYBERNACLE, (winter lodgment) is that part of a plant which defends the embryo, or future shoot, from external injuries during the winter; and according to Linnæus, is either a bulb or a bud.\$-See gemmation under habit of plants.

I. A BuLB, (bulbus) is a large sort of bud produced under ground, placed upon the caudex of certain herbaceous plants; hence called bulbus plants; all of which are perennial, that is,

* See the note at the end of luxuriant flowers. The name that constitutes the variety is to be placed immediateiy after the specific name, as flore pleno, corolla rubra, \&c.

+ In respect to leaves, which are mentioned as a distinction of species, yet subject to variety, it may be necessary to observe, that in general the leaves are constant as to figure and situation; but vary in respect to number of fingers, or lobes, in digitated and winged leaves, and in growing by threes, fours, or fives: Curled and variegated leaves are also a frequent variety, and they often differ as to size and colour.

$¥$ From Linnæus's definition of the hybernacle, it seems to appear that tuberous roots, and seeds, might with equal propriety bear that appellation with the bulb and the bud; but he hath thought proper to give them a different distinction; for Linnæus does not allow the bulb and bud to be roots, but hybernacles or winter lodgments, into which the whole plant retires during the winter, in miniature; for the bulb is exactly the same under ground, as the bud is above. 
perpetuated by their bulbs or ground buds, as well as by seeds; they are therefore improperly called roots, being only the hybernacle of the future shoot. Bulbs are of the following sorts:

1st. A scaly bulb, (bulbus squamosus) consisting of scales laid over each other like tiles, as in the lily.

2d. A solid bulb, (solidus) consisting of a solid substance, as in tulips.

3d. A coated bulb, (tunicatus) consisting of many coats infolding each other, as in onions.

4th. A stem bulb,* (caulinus) which is produced not only. from the sides of the principal bulb, called a sucker, or off set; but from other parts of the stem; as in crow, or wild garlic, and in some species of onion and lily (hence called bulbiferous); in the onion they are produced at the origin of the umbel of flowers, instead of seeds.

II. A BuD (gemma) is the embryo of the plant seated upon the stem and branches, covered with scales; and if a leaf bud, it consists of radicles which descend along the bark into the earth; and is also furnished with umbilical vessels, which are inserted into the alburnum, and form a part of it, and descending into the earth, supply it with its first nutrition. (Phytologia). In general there are three sorts of buds :-1st. that containing the flower only, as in poplar, ash, \&c. where the leaf-buds and flower-buds are distinct:-2d. that containing the leaves only, as in birch, hazel, \&c.:- and 3d. that containing both flower and leaves, as in the generality of plants; and these last sometimes contain leaves and male flowers, sometimes leaves and female flowers, sometimes leaves and monoclinian flowers. Every flower-bud dies when it hath perfected its seed like an annual plant; and it is said to be the same with respect to flowering bulbs, they also die after having flowered a few times and perfected their seed, and produced other smaller bulbs to perpetuate their progeny.

* Other bulbs, besides those here mentioned, were formerly enumerated, (viz.) the jointed bulb, as in moschatel; and the double bulb, as in orchis. 
Annual plants are only renewed from seeds, and several other plants, both trees and shrubs, have no winter buds: It is also observed in hot countries, that few plants have buds, or at least they are without that scaly covering, which seems essential to a bud, and constitutes the hybernacle; instead whereof are protruded small feather-like branches from the wings of the leaves; (defence and protection from cold not being necessary); whereas in cold countries most plants have buds, which are wrapped up all the winter in readiness to greet the approaching spring.

I may, lastly, take notice of what is called the SLEEP of plants, which, according to Linnæus, happens various ways, as by converging, including, surrounding, fortifying, conduplicating, involving, diverging, depending, inverting, imbricating. This disposition in plants is very remarkable in chickweed, pimpernel, dandelion, goat's-beard, \&c. which expand their flowers only at certain times of the day, and shut them up at certain times, or at the approach of night or a storm; which shews the great care a plant takes to protect and invigorate her feeble offspring, which may be called the storge of plants, as well as animals.-From hence is constituted what Linnæus calls the horologe or watch of Flora, shewing the hours of the day from what he calls the rising and setting of flowers; from hence may also often be prognosticated a change of weather.* And in many plants, not only the flowers, but the young shoots are defended from external injuries, by the nearest leaves converging and enclosing the tender rudiments. The anerrhoa carambola is very remarkable for this quality of sleeping. - See the note to the genus.

* The calendula pluvialis (violet and white-coloured African marygold) opens between 6 and 7 A. M. and shuts up at 4 P. M. if the weather is dry; but if it doth not open its flowers at 7 , you are sure to have rain that day; sometimes the hasty surprize of a thunder storm will vary the above prognostic.-If the sonchus sibiricus (Siberian sow-thistle) shuts up its flowers in the night, the following day is generally dry, but if the flowers remain open all night, the next day is generally rainy.-The same observations may be made of several of the English plants. 


\section{TABLE}

\section{of \\ CLASSES AND ORDERS:}

According to the Systema Vegetabilium and Supplementum, Plantarum, \&. .

CLASSES. ORDERS.

1 MONANDRIA..... 1 Monogynia. 2 Digynia.

2 DYANDRIA....... 1 Monogynia. 2 Digynia. 3 Trigynia.

3 TRIANDRIA. .... 1 Monogynia. 2 Digynia. 3 Trigynia.

4 TETRANDRIA. .. 1 Monogynia. 2 Digynia. 3 Tetragynia.

5 PENTANDRIA. .. 1 Monogynia. 2 Digynia. 3 Trigynia. 4 Tetragynia. 5 Pentagynia. 6. Polygynia.

6 HEXANDRIA. .... 1 Monogynia. 2 Digynia. 3Trigynia. 4 Tetragynia. 5 Polygynia.

7 HEPTANDRIA. .. 1 Monogynia. 2 Digynia. 3 Tetragynia. 4 Heptagynia.

8 OCTANDRIA. .... I Monogynia. 2 Digynia. 3 Trigynia. 4. Tetragynia.

9 ENNEANDRIA. .. 1 Monogynia. 2 Trigynia. 3 Hexagynia.

10 DECANDRIA. .. 1 Monogynia. 2 Digynia. 3 Trigynia. 4 Pentagynia. 5 Decagynia. 
11 DODECANDRIA. 1 Monogynia. 2 Digynia. 3 Trigynia. 4 Pentagynia. 5 Dodecagynia.

12 ICOSANDRIA. . 1 Monogynia. 2 Digynia. 3 Trigynia. 4 Pentagynia. 5 Polygynia.

13 POLYANDRIA. . 1 Monogynia. 2 Digynia. 3Trigyniø. 4 Tetragynia 5 Pentagynia. $6 \mathrm{Hex}$ agynia. 7 Polygynia.

4. DIDYNAMIA..... I Gymnospermia. 2 Angiospermia

15 TETRADYNAMIA. 1 Siliquosa. 2 Siliculosa.

16 MONADELPHIA. 1 Triandria. 2 Pentandria. $3 \mathrm{Hep}$ tandria. 4 Octandria. 5 Enneandria. 6 Decandria. 7 Endecandria. 8 Dodecandria. 9 Polyandria.

7 DIADELPHIA. . 1 Pentandria. 2 Hexandria. 3 Octandria. 4 Decandria.

3 POLYADELPHIA. 1 Pentandria. 2 Icosandria. 3 Polyandria.

19 SYNGENESIA. ․ 1 Polygamia æqualis. 2 Polygamia superitua. 3 Polygamia frustranea. 4. Polygamia necessaria. 5 Polygamia segregata. 6 Monogamia.

20 GYNANDRIA. .. 1 Diandria. 2 Triandria. 3 Tetrandria. 4, Pentandria. 5 Hexandria. 6 Octandria. 7 Decandria. 8 Dodecandria: 9 Polyandria.

21 MONOECIA. ... 1 Monandria. 2 Diandria. 3 Triandria. 4 Tetrandria, 5 Pentandria. 6 Hexandria. 7 Heptandria. $8 \mathrm{Po}$ lyandria. 9 Monadelphia. 10 Syngenesia. 11 Gynandria. 
CLASSES.

ORDERS.

22 DIOECIA. ..... 1 Monandria. 2 Diandria. 3 Trian. dria. 4 Tetrandria. 5 Pentandria. 6 Hexandria. 7 Octandria. 8 Enneandria. 9 Decandria. 10 Dodecandria. 11 Icosandria. 12 Polyandria. 13 Monadelphia. 14 Syngenesia. 15 Gynandria.

23 POLYGAMIA. . - 1 Monoecia. 2 Dioecia. 3 Trioecia。

24 CRYPTOGAMIA. 1 Filices. 2 Musci. 3 Algæ. 4 Fungi $_{s}$ APPENDIX. .... Palmæ。 


\section{NOTE:}

TH $\mathrm{E}$ number of genera is taken from the sth edition of the Gen. Plantarum printed in 1791; with some others.

The number of species is taken from the Systema Vegetabilium; 14th edition, printed in 1784 , with some others since discovered.

The distinctions of the genera in the several orders are taken from the synopsis to each class, in the same publication.

The growth, and places where principally native, are taken from Aiton, and other botanists.

The number of species indigenous to the British Isles, are taken from Broughton's Enchiridion Botanicum.

- In the column under growoth; $t$, stands for tree; $s$, for shrub; and $h$, for herb.

Vegetables, saith Linnæus, hath life without voluntary motion; his climax runs thus, lapides crescunt; vegetabilia crescunt et vivunt; animalia crescunt, vivunt, et sentiunt; and this was the doctrine of other authors before Linnæus; it may be right in a general sense, but if we accurately examine the connecting links of the three kingdoms, we shall find ourselves staggered in the definition. His System of Plants makes no difference between trees, shrubs, and herbs, yet the distinction is of great antiquity with other writers: The difference between trees and herbs is-very- 
obvious; but the limit between trees and shrubs is not accurately ascertained. Linnæus thinks the bud the best distinction, trees having buds, and shrubs no buds; but he immediately acknowledges this distinction to be fallaceous, as many large trees in hot climates have no buds. Dr. Alston thinks the difference lies in the bark, that trees have an outer and inner bark, (cortex and liber) and generally a sap, (alburnum) but that the covering to shrubs is not a bark but a cuticle or simple skin; but this wants confirmation. We can therefore only say that a tree is a perennial plant rising to a great hight, with a simple, woody, durable, branching trunk, producing wood fit for timber: The same definition holds with respect to shrubs, only, that they do not rise to so great an hight, the trunk not so simple, the branches more bushy, and not producing timber.

An herb is a plant with a succulent stem or stalk, not woody, and which generally dies down to the ground every year; and is either annual, biennial, \&c. or perennial.

The duration of plants Linnæus thinks so inconstant, that he never employs it in specific differences. In hot climates that have a perpetual summer, most plants are trees or shrubs, or at least perennial; yet many, when removed to colder climates, loose their woody substance, and become herbaceous, and sometimes annual, as ricinus, mirabilis, tropcolum, beta, origanum, lavater $a_{\text {, }}$ \&c.-Milne's Botan. Dict. 
THE

\section{CLASSES, ORDERS,}

A N D

\section{GENERA :}

According to the SEXUAL SYSTEM of LINNAUS.

\section{CLASS I. MONANDRIA.}

(ONE FERTILE* STAMEN OR MALE, HAVING THE ANTHERA.)

Consisting of such plants as bear monoclinian flowers, fur* nished with only one stamen or male.

And, to avoid repetition, it may be observed, that all the classes, except the last four, and part of the class syngenesia, regularly consist of monoclinian flowers, that is, where the males and females are in the same bed or flower.

This class contains two orders.

* Many flowers will appear to have more stamina than is the character of the class to which they belong; but those are only to be numerated which have antheræ; the others are called larren, as being imperfect. 


\section{ORDER I. MONOGYNIA.}

(ONE FEMALE.)

Containing such plants as have only one female: under the following distinctions:

\section{1st. Scitamineous* beneath; or fruit-celled beneath.}

\begin{tabular}{|c|c|c|c|c|c|}
\hline & Genera. & Growth. s & $\begin{array}{l}\text { No of } \\
\text { species. }\end{array}$ & Native of & $\begin{array}{l}\text { Species in } \\
\text { Britain. }\end{array}$ \\
\hline 1 & Alpinia & $\mathrm{h}$ & 2 & America & \\
\hline & Amomum & $\mathrm{h}$ & 6 & W. Indies & \\
\hline 3 & Canna & h & 3 & America & \\
\hline 4 & Costr & h & 1 & Arabia and Indies & \\
\hline 5 & Cucullaria & h & 1 & & 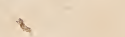 \\
\hline & Curcuma & $\mathrm{h}$ & 2 & India & \\
\hline 7 & Kæmpferia & h & 2 & E. Indies & \\
\hline & Maranta & $\mathrm{h}$ & 3 & India & \\
\hline & Myrc & $\mathrm{h}$ & 1 & Surinam & \\
\hline 10 & Qualea & h & 1 & & \\
\hline & Renealmia & $\mathrm{h}$ & 1 & Surinam & \\
\hline & Thalia & h & & America & \\
\hline & & $2 \mathrm{~d}$. & 1. One & e-seeded: & \\
\hline & $\mathrm{Bc}$ & $\mathrm{h}$ & 6 & La-vera-crux & \\
\hline & & $\mathrm{h}$ & 2 & Europe & Brit. \\
\hline & Salicornia & $s \& h$ & 6 & Arabia & Brit. \\
\hline & Pollichia & & 1 & Cape & \\
\hline
\end{tabular}

* Scitamineous, (from scitamentum) because some of the plants afford delicious fruit. Scitaminece is also the name of the 8 th order in Linnæus's Fragments of a Natural Method, containing most of the above plants.

+ Cardamom seeds are from a species of amomum, called amomum cardamomum.

$\ddagger$ Maranta arundinacea (Indian arrow-root) called so, because the Indians, by using it as a poultice, expel the poison of their arrows, it also extracts the poison of the manchineel tree, and the venom of insects. And the root dried and made into powder, and mixed with hot water, is said to make an agreeable and nutritious beverage, and may be bought at the shops of the druggists; and the best sort sells for about $7 \mathrm{~s} .6 \mathrm{~d}$. per $\mathrm{lb}$.

\$ Hippuris is called mare's-tail, to distinguish it from equisetum, (horse-tail) ; it hath a single jointed stalk, and at each joint are twelve (more or less) leaves, placed in a whorl; to each of these leaves, close to the stalk, belongs a little flow er, with one stamen, one pistil, and one seed. 


\section{ORDER II. DIGYNIA. \\ (TWO FEMALES.)}

3\% Genera. Growth. species. Native of $\quad \begin{gathered}\text { Species in } \\ \text { Britain. }\end{gathered}$

1st. Plants.

17 Blitum

18 Callitriche

h 2 Spain, Tartary

h 2

19 Corispermum

20 Lacistema

h 2 Tartary

h 1

2d. Grassy.

21 Cinna

22. Mniarum

h 1 Canara

h 1

Brit. 2 


\title{
CLASS II. DIANDRIA.*
}

\author{
(TWO STAMINA, OR MALES.)
}

Containing three orders.

ORDER I. MONOGYNIA.

(ONE FEMALE.)

No Genera. Growth. species. Native of $\quad \begin{aligned} & \text { Species in } \\ & \text { Britain. }\end{aligned}$

\section{1st. Flowers beneath, one-petaled, regular.}

\begin{tabular}{|c|c|c|c|}
\hline \multicolumn{2}{|c|}{1 Arouna (cor. none) h } & \multicolumn{2}{|c|}{1} \\
\hline 2 Chionanthus & $\mathrm{s}$ & 2 & South Carolina \\
\hline 3 Eranthemum & s & 4 & Ethiopia \\
\hline 4 Jasminum & s & 9 & India \\
\hline 5 Ligustrum & $\mathrm{s}$ & 2 & \\
\hline Nyctanthest & s & 1 & India \\
\hline Oleat & $\mathrm{s}$ & 6 & Spain \\
\hline Phillyrea & $\mathrm{s}$ & 3 & Europe \\
\hline Sciuris & h & 1 & \\
\hline Syringa & $\mathrm{s}$ & 3 & Persia \\
\hline
\end{tabular}

* Several plants of this class diandria, are so similar to many of the class didynamia, that it is often very difficult to distinguish them: The flowers are nearly of the same form, and though many have properly only two stamina (the other two wanting antheræ); yet have filaments so very like stamina, that botanists have sometimes confounded the two classes, as to several plants.

+ Nyctanthes sambac (Arabian fasmine) flowers, and gives its perfume in the night, and not in the day; whence the name. But Aiton has taken sambac (to which he gives several varieties) from nyctanthes, and placed it under jasminum; and only allows one species to nyctanthes, viz. arbor-tristis.

¥ The European olive (olea Europoa) bears the fruit for pickling; but as there are many varieties of this species; that most in esteem grows in France, called the province olive, both for the flavour of the fruit, and its oil. The olives we have from Spain are much larger, but both the fruit and the oil have a disagreeable flavour. In China the manner of gathering their olives is very convenient; they bore a hole in the trunk of the tree, and after having put some salt into it, they stop it up, and in a few days the fruit drops of itselfo-Abbe Grosier's description of China, 1788. 
No Genera. Growth. species. Native of $\quad \begin{gathered}\text { No of } \\ \text { Britain. }\end{gathered}$

2d. Flowers beneath, one petaled, irregular.

Fruit capsuled.

11 Calceolaria

12 Dianthera

13 Gratiola

14. Justicia

15 Pæderota

16 Pinguicula

17 Schwenkia

18 Veronica

19 Utricularia*

20 Wulfenia h 3 Peru

h 7 . America

h 6 Alps, America

s \& h 30 Ceylon, \&c。

h 5 Africa

h 4. Portugal

h 1 America

h 40 America

h 9 Alps

1 Carinthia
Brit. 2

Brit. 15

Brit. 2

\section{3d. Flowers beneath, one-petaled, irregular.}

Fruit seed-naked.

\section{Amethystea \\ 22 Collinsoniat \\ 23 Cunila \\ 24. Lycopus \\ 25 Monarda \\ o6 Rosmarinus \\ 27 Salviaf}

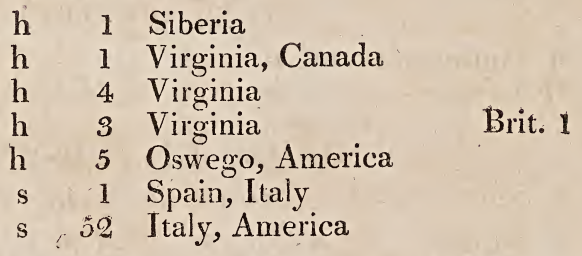

* In utricularia (bladder-wort) the roots are loaded with membranaceous bladders.

+ It hath been observed in many plants, as in lilium, ruta, dictamnus albus, saxifraga, parnassia, \&c. that at the proper times the stamina make the first advances by bowing down in their turns to the female; but in collinsonia canadensis, vigella, damuscena, spartium scoparium, and some others, the lady seems to make the first arivance, by bowing first to one or more of her hustands for a day or two, and then to the others. But what is still more remarkable ; the common berberry hath six et ect stamina resting on the petals, under whose concave tops are sheltered. the antheræ; and on touching the inside of the filament near its base, with $a$ bristle or fine wire, the stamen instantly incurvates, so as the anthera to embrace the stigma.-In the kalmia the ten stamens lie round the pistil, like the radii of a wheel, and each anther is concealed in a nich of the coral to protect it from cold and moisture; these anthers rise separately from their niches, and approach the stigma of the pistil for a time, and then recede to their former situations.

In salvia, the singular cross thread of the stamina constitutes the essential character of the genus : the rudiments of two stamina appear in the mouth of the flower, but have no antheræ. - Sage and clary are distinct plants by other writers, but by Linnæus, they both come under the genus salvia, notwithstandino some little difference in the flower. 


\begin{tabular}{|c|c|c|c|}
\hline Genera. & Growth. & $\begin{array}{l}\mathrm{N}^{\text {No of }} \\
\text { species. }\end{array}$ & Native of \\
\hline Verbena* & h & 19 & America, Chili \\
\hline Ziziphor: & h & 4 & Virginia \\
\hline
\end{tabular}

4th. Flowers beneath, four-petaled.

30 Thouinia

$$
\text { t } 1 \text { Ceylon }
$$

5th. Flowers beneath, fire-petaled.

31. Dialium
32 Ancistrum
33 Circat
34 Globba
35 Morina

s 1 India

6th. Flowers above.

$\begin{array}{llll} & 2 & \text { New Zealand, Peru } \\ \text { h } & 2 & \text { France, Alps } & \\ & 4 & \text { E. Indies } & \text { Brit. } 2 \\ \text { h } & 1 & \text { Persia }\end{array}$

\section{ORDER II. DIGYNIA. \\ (TWO FEMALES.)}

$\begin{array}{llll}36 & \text { Anthoxanthum } \\ 37 \text { Crypsis } & 5 & 5 & \\ \text { h } & 1 & \text { S. of Europe }\end{array}$

Brit, i

\section{ORDER III. TRIGYNIA.}

(THREE FEMALES.)

38 Piper $\quad \mathrm{s} \& \mathrm{~h} \quad 25$ E. and W. Indies

* The English species of vervain, called simpler's joy (verbena officinalis) hath four stamina, as hath also the verbera triphylla (sweet-scented vervain) and most of the other species; that it is necessary to examine the essential character.

+ Enchanter's nightshade (circæa lutetiana) was much celebrated in the mys: teries of witchcraft, and for the impious purpose of raising the devil. It grows amidst the mouldering bones and decayed coffins in the ruinous vaults of Sleaford church, in Lincolnshire.

Botanic Gurden.

$\mp$ The grateful smell to hay is said ehiefly to be given by the British species of vernal grass, anthoxanthum odoratum.

$\S$ The leaves of the piper-letle are 'esteemed cordial, and give a fine flavour tơ the breath, for which they are much used in the East.-In Peru, this shrub is also much used, and is there called cuca. (See areca). The betle leaves are in great request throughout India, from being used to wrap round the areca nut, in order for chewing; the nut is like a nutmeg in size and shape, but differs in taste. The inside is of a lively red colour, and has an agreeable flavour: The Indians in general consume a great quantity of these nuts.- In the Genileman's Mag. for Dec. 1805, this nut is highly spoke of.

White pepper is from the same plant as the black pepper, (piper nigrum) it is made white by being laid in lime before it is dry, by which it loses its external coat. 


\title{
CLASS III. TRIANDRIA.
}

\author{
(THREE STAMINA OR MALES.)
}

Containing three orders:

\section{ORDER I. MONOGYNIA.}

\section{(ÓNE FEMALE.)}

\begin{tabular}{|c|c|c|c|c|}
\hline Genera. & Growth. & $\begin{array}{l}\text { No of } \\
\text { species }\end{array}$ & Native of & $\begin{array}{l}\text { Species in } \\
\text { Britain. }\end{array}$ \\
\hline & 1st & Flow & ers above. & \\
\hline 1 Antholyza & h & 7 & Africa & \\
\hline 2 Aristea & $\mathrm{h}$ & 1 & Cape of Good Hope & \\
\hline 3 Crocus* & $\mathrm{h}$ & 1 & Europe & Brit. 1 \\
\hline 4 Comocladia & $\mathrm{s}$ & 1 & Jamaica & \\
\hline 5 Dilatris & $\mathrm{h}$ & 3 & Cape & \\
\hline 6 Gladiolus & h & 24 & Europe, Africa & \\
\hline 7 Iris & h & 45 & Europe, China & Brit. 2 \\
\hline 8 Ixia & $s \& h$ & 24 & Alps, Africa & \\
\hline 9 Macrolobium & $\mathrm{h}$ & 1 & & \\
\hline 10 Marica & h & 1 & & \\
\hline 11 Melothria & h & 1 & Virginia & \\
\hline 12 Moræa & h & 12 & Africa & \\
\hline 13 Oxybathus & & & Peru & \\
\hline 14 Rohrra & h & 1 & & \\
\hline 5 Tapura & $\mathrm{h}$ & 1 & & \\
\hline Tonsella & h & 1 & & \\
\hline
\end{tabular}

* Crocus sativus is the only known species of this genus, with two very singular varieties, viz. officinalis and vernus; the first is the autumnal crocus, the latter is the vernal crocus; these plants are one of the wonders of the vegetable creation, being so similar as no specific difference can be obtained, yet flowering at so great a distance of time from each other: The flower of the crocus, as also the colchicum, hath no stalk, but the tube is very long, proceeding from the bulb; from the crocus sativus officinalis (which flowers in autumn, and bears a purple blue flower) is produced the saffron of the shops, which Mr. Miller says, is the stigmata of the three divisions of the style, with part of the style itself; these being properly dried, are made inte cakes for use; it is said to be very narcotic or anodyne.

N.B. This plant hath many varieties. 


\begin{tabular}{|c|c|c|c|c|c|}
\hline No & Genera. & Growth. & $\begin{array}{l}\text { No of } \\
\text { species. }\end{array}$ & Native of & $\begin{array}{l}\text { Species int } \\
\text { Britain. }\end{array}$ \\
\hline 17 & Valeriana* & $\mathrm{h}$ & 21 & France, Chitu, \&c. & Brit. 4 \\
\hline 18 & Witsenia & h & & Maura & \\
\hline & * & $2 \mathrm{~d}$. & Flowe & ers beneath. & \\
\hline 19 & Callisia & $\mathrm{h}$ & 1 & America & \\
\hline 20 & Cneorum & $\mathrm{s}$ & 1 & Spain & \\
\hline 21 & Commelina & h & 9 & W. Indies, Africa & \\
\hline 22 & Comocladia & s & 2 & America & \\
\hline 23 & Hippocratea & h & 1 & America & \\
\hline 24 & Loetlingia & $\mathrm{h}$ & 1 & Spain & \\
\hline 25 & Olax & $\mathrm{t}$ & 1 & Ceylon & \\
\hline 26 & Ortegia & & 2 & Spain & \\
\hline 27 & Polycnemum & h & 1 & France, Italy & \\
\hline 28 & Rotala & $\mathrm{h}$ & 1 & E. Indies & \\
\hline 29 & Rumphia & $\mathrm{s}$ & i & Amboyna & \\
\hline 30 & Syena & $\mathrm{h}$ & 1 & & \\
\hline 31 & Tamarindust & $\mathrm{t}$ & 1 & E. and W. Indies & \\
\hline 32 & Wachendorfia & h & 3 & Africa & \\
\hline 33 & Willichia & $\mathrm{h}$ & 1 & Mexico & \\
\hline 34 & Xiphidium & $\mathrm{h}$ & 1 & & \\
\hline 35 & Xyris & & 1 & India & \\
\hline
\end{tabular}

3d. Flowers grassy, with valvelets of the calyx-glume.

\begin{tabular}{|c|c|c|c|c|}
\hline 36 Cyperus $f$ & $\mathrm{~h}$ & 32 & Jamaica, Egypt, \&c. & Brit. 1 \\
\hline 37 Eriophorum & Ir & 5 & Europe & Brit. 2 \\
\hline 38 Fuirena & $\mathrm{h}$ & 1 & Surinam & \\
\hline 9 Kyllingia & $\mathrm{s}$ & 4 & E. and W. Indies & \\
\hline o Lygeum & h & 1 & Spain & \\
\hline Nardus & h & 6 & Europe & Brit. 1 \\
\hline Pommereulla & h & 1 & India & \\
\hline 3 Schœenus & $\mathrm{h}$ & 13 & Europe & Brit. 7 \\
\hline Scirpus & $\mathrm{h}$ & 41 & Ámerica & Brit. 13 \\
\hline Spartina & $\mathrm{h}$ & 1 & & \\
\hline
\end{tabular}

* Valerians differ greatly in several parts; as in the corolla being regular or irregular; in the stamens being $1,2,3$, or 4 ; the fruit one-seeded, or two-seeded, naked, crowned with a pappus, \&c.-These plants may be generally known (when not in flower) by the roots being scented, and two leaves at each juint opposite.

+ Tamarindus (the tamarine tree) renders the air under its shade very unwholesome.

$¥$ Cyperus papyrus (the Egyptian papyrus, or paper of the antient Egyptians) is a triangular rush, growing 8 or 9 feet high, and an inch thick, bearing a woolly tuft. 


\title{
ORDER II. DIGYNLA.**
}

\author{
(TWO FEMALES.)
}

No Genera. $\quad \begin{gathered}\text { No of } \\ \text { 1.t. Flowth. species. Native of }\end{gathered}$
ine-flowered, straggling.

Species in Britain.

\begin{tabular}{|c|c|c|c|c|}
\hline 46 Agrostis & $\mathrm{h}$ & 26 & Europe & Brit. $\mathrm{S}$ \\
\hline 47 Alopecurus & h & 8 & Europe, Indies & Brit. 6 \\
\hline 48 Anthistiriat & $\mathrm{h}$ & I. & India & \\
\hline 49 Aristida & $\mathrm{h}$ & 6 & Jamaica & \\
\hline 50 Bobartia & $\mathrm{h}$ & 1 & India & \\
\hline 51 Cornucopiæ & h & 2 & Smyrna & \\
\hline 52 Dactylis & $\mathrm{h}$ & 5 & Virginia & Brit. 2 \\
\hline 3 Lagurus & $\mathrm{h}$ & $\mathcal{Q}$ & Italy & \\
\hline 54 Milium & $\mathrm{h}$ & 8 & Europe & Brit. 2 \\
\hline 55 Muhlenbergia & h & 1 & & \\
\hline 56 Panicum $\ddagger$ & $\mathrm{s} \& \mathrm{~h}$ & 34 & E. and W. Indies & Brit. J \\
\hline 57 Paspalum & h & 6 & America & \\
\hline 58 Phalaris & h & 13 & Europe & Brit. 3 \\
\hline 59 Phleum & $\mathrm{h}$ & 5 & Europe & Brit. 3 \\
\hline 60 Rottboella & h & 5 & India & \\
\hline Saccharum \| & h & 5 & Indies & \\
\hline Stipa & $\mathrm{h}$ & 9 & Europe & Brit \\
\hline
\end{tabular}

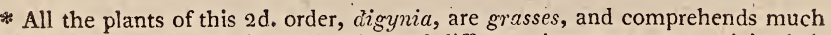
the greater part; though there are others of different characters arranged in their proper classes, as in MONANDRIA, cinna.-DIANDRIA, anthoxanthum.-HEXANDRIA, oryza, ehrharta, gahnia.-MONCECIA, zea, tripsacum, coix, olyra, aizania, pharus.-DICECIA, restio.-POLYGAMIA, agilops, cenchrus, ischamum, apluda, holcus, andropogon, manisuris, chrysitrix, spinifex.-Grass is defined to be a plant, having simple leaves, a stem generally jointed and tubular, a husky calyx. (called gluma) and the seed single. The leaves are food for cattle, the small seeds for birds, and the larger grain for man : none are poisonous. And it is observed, that nature hath so provided, that cattle (in grazing) seldom eat the flower intended to produce seed, unless compelled by hunger.

+ Anthistiria is easily distinguished from all the known genera of grasses by its four-valved calyx, for the division of the calyx is very essential in forming the character of grasses.

$\ddagger$ Panicum artorescens, (tree panic grass) whose stem is scarce thicker than a goose quill, rises in India as high as the tallest trees.

$\$$ Striped riband grass, or reed grass, according to Linnæus, is phalaris arundenacra; according to Aiton, it is arundo coloruta.

II Though sugar is chiefly obtained from the saccharum officinarum, which is a perennial plant, yet several other vègetables secrete a sweet juice easily converted into sugar; as in America, a considerable quantity is obtained from the acer 


\begin{tabular}{|c|c|c|c|c|}
\hline Genera. & Grow & $\begin{array}{l}\text { No of } \\
\text { species. }\end{array}$ & Native of & $\begin{array}{l}\text { Species in } \\
\text { Britain, }\end{array}$ \\
\hline \multicolumn{5}{|c|}{ 2d. Flowers two-flowered, straggling. } \\
\hline Aira & h & 13 & Europe & Brit. 7 \\
\hline Melica* & $\mathrm{h}$ & 7 & Europe & Brit. 3 \\
\hline Perotis & $\mathrm{h}$ & 1 & E. Indies & \\
\hline
\end{tabular}

3d. Flowers many-flowered, straggling.

\begin{tabular}{|c|c|c|c|c|}
\hline 66 Avenat & & 21 & Siberia & Brit. 6 \\
\hline 67 Arundot & s \& h & 6 & Europe & Brit. 4 \\
\hline 68 Briza & $\mathrm{h}$ & 5 & Europe & Brit. 2 \\
\hline 69 Bromus & h & 26 & Europe & Brit, 12 \\
\hline 0 Festuca & $\mathrm{h}$ & 19 & Europe & Brit. 11 \\
\hline Poa & h & 34 & Europe & Brit. 14 \\
\hline Unióla & $\mathrm{h}$ & 4 & Carolina & \\
\hline
\end{tabular}

saccharinum; in New Spain it is procured from the agave americana; it is like. wise obtained from asclepias syriaca, and zea mays; in Kamshatska it is produced from heracleum syphondylium, and fucus saccharinus. -The museum of natural history at Paris, has received several plants of the violet sugar cane from Batavia, and the whits from Otaheite, which are said to yield a greater product than the common sort in the West Indies.

* In melica, the rudiment of a third floret, standing upon a little footstalk between the other two florets, gives the essential character.

In avena, the essential character consists in the jointed twisted awn, growing from the back of the corolla.-Avena sativa (the common oat) which hath three varieties, black, white, and brown, is described as having two seeds in a calyx, but the white oat hath generally only one. The wild oat (avena fatua) is described as having three flowers in a calyx, but in England it hath generally only two seeds.

¥ The drug in high estimation in India, as a refrigerant, called tabasheer, is said to be contained in the joints of the arundo bambos: and the arundo donax is imported into England principally from Spain, to be manufactured into weavers' slaies. The instruments used by the Turks and Persians, \&c. in writing their beautiful manuscripts are formed of an Egyptian reed (arundo calamagrostis) which is much properer than our pens, to make those exquisitely fine strokes and flourishes, in which eastern manuscripts so greatly abound.-It is said that the male and female bamboo always grow together, and if one is felled, the other very soon dies.

\$ The seeds of festuca fuitans (flote fesure grass) are gathered yearly in Poland, and from thence sent into Germany, and even to Sweden, and sold under the name of manna seeds, from their sweet and agreeable flavour. They are much used at the tables of the great, on account of their nutritious quality and pleasant taste. They make an excellent foundation for soup and puddings; and their mucilage, prepared with sugar and white wine, makes an excellent nourishment for invalids. 
$N^{\circ}$ of

No Genera. Growth. species. Native of

4th. Flowers spikes, with receptacle awled.

73 Cynosurus

74 Elymus

75 Hordeum*

76 Lappago

77 Lolium

78 Secale

79 Triticum h

13 Europe

h 10 Europe, America

h 8 Italy

h 1 ,

h 4

h 4 Asia, Europe

h 14 Europe
Brit. 3

Brit. 3

Brit. 3

Brit. 4

Brit. 3

\section{ORDER HI. TRIGYNIA,}

(THREE FEMALES.)

1st. Flowers beneath.

80 Eriocaulon

81 Holosteum

82 Koenigia

$\begin{array}{lll}\mathrm{h} & 5 & \text { Brazils } \\ \mathrm{h} & 4 & \text { Jamaica } \\ \mathrm{h} & 1 & \text { Iceland }\end{array}$

Brit. I

* French, or pearl larley, is one of the species of barley (hordeum) with the husk taken off, by which means it becomes whitish, and somewhat of the colour of pearl.

+ In the memoir of M. le Marquis de Turgot on the cifferent sorts of wheat (triticum) cultivated in some parts of Lower Normandy, he mentions that the stalks of several of the sorts are nor hollow, but filled with pith.

Royal Society of Agriculture at Paris, v. ii.-1785.

The common Lammas wheat (triticum hylernum) is described as having four flowers in a calyx, but it rarely happens in England that there are more than two or three seeds or corns, which number is most desirable, for if more, the corn is small.

$\mathrm{Mr}$. Needham observed, that in the ripe pollen of every flower examined by the microscope, some vesicles are perceived from which a fluid had escaped; and that those, which still retain it, explode if they are wetted, like an eolipile suddenly exposed to a strong heat. These observations have been verified by Spallanzani and others. Hence rainy seasons may make a scarcity of grain, by bursting the pollen of the flower of corn, before it arrives at the stigma of the flower. Botanic Garden.

If wheat is long masticated, or a little of the flour made into a paste with water, and then washed with the hands under water, which must be frequently changed, till it is no longer discoloured, that is, till the mucilage and starch are washed from it, then what remains is called the gluten, which is indissoluble in either hot or cold water, and if the corn be good, is elastic, and will contract itself when drawn out; but if the corn hath begun to heat, it is brittle; and if the corn hath fermented, none of the gluten will be obtained, and the corn is then bad, and will not grow.

Phyiologia. 
No Genera. Growth. species. Native of

83 Lechea

2 Canada

84. Meborea (cor, none) h i

85 Minuartia

86 Mollugo

h 3 Spain

87 Montia

h 4 Ceylon, \&c.

8s Polycarpon

89 Queria

90 Triplaris

h 1

h 2 Italy

h 2 Spain

s 2 America

2d. Flowers above,

9 Proserpinaca h 1 Virginia

Brit. 1

Brit. 1 


\title{
CLASS IV. TETRANDRIA.*
}

\author{
(FOUR STAMINA OR MALES.)
}

Containing three orders.

\section{ORDER I. MONOGYNIA.}

$$
\text { (ONE FEMALE.) }
$$

\section{Growth, $\begin{gathered}\text { No of } \\ \text { species }\end{gathered}$ \\ 1st. Flowers one-petaled, one-seeded, berieatt.}

$\begin{array}{llrrl}1 & \text { Choetocarpus } & \text { h } & 1 & \\ 2 & \text { Ernodea } & \text { h } & 1 & \\ 3 & \text { Globularia } & \text { s \& h } & 7 & \text { Italy } \\ 4 \text { Hydrophylax } & \text { h } & 1 & \text { Sea-shore } \\ 5 & \text { Opercularia } & \text { h } & 1 & \\ 6 & \text { Protea } & \text { s } & 61 & \text { Cape of G. Hope } \\ 7 & \text { Rhopala (3 pet.) } & 1 & \end{array}$

2d. Flowers one-petaled, one-seeded, above, aggregate.

S Allionia

9 Cephalanthus

10 Dipsacus

11 Knautia

12 Labatia

13 Scabiosa

$\begin{array}{rrll} & 2 & \text { America } & \\ \text { s } & 1 & \text { W. Indies } & \\ \text { h } & 4 & \text { France } & \text { Brit. 2 } \\ \text { h } & 4 & \text { Archipelago } & \\ \text { h } & 1 & & \\ \text { h } & 34 & \text { Italy, \&c. } & \text { Brit. } 3\end{array}$

3d. Flowers one-petaled, one-fruited, $\uparrow$ beneath.
14. Egiphila:

15 Acquartia s 1 Martinico

s 1 America

* The stamina in this class being of equal length, is the distinction from the class didynamia, where they are two long and two short.

+Onc-fruited means a single seed-ressel undivided, containing several seeds. 


\begin{tabular}{|c|c|c|c|c|}
\hline Genera. & Growth. & $\begin{array}{l}\text { No of } \\
\text { species. }\end{array}$ & Native of & $\begin{array}{l}\text { Species int } \\
\text { Britain. }\end{array}$ \\
\hline 16 Blæria & $\mathrm{s}$ & 5 & Cape of $G$. Hope & \\
\hline 7 Buddleia & $\mathrm{s}$ & 4 & W. Indies & \\
\hline Callicarpa & $s$ & 3 & Virginia, Japan & \\
\hline Centunculus & $\mathrm{h}$ & 1 & & Brit. 1 \\
\hline Exacum & $\mathrm{h}$ & 4 & India & \\
\hline Lasiostoma & $\mathrm{h}$ & 1 . & & \\
\hline Myrmecia & $\mathrm{h}$ & 1 & & \\
\hline Penæa & $\mathrm{s}$ & 8 & Athiopia & \\
\hline Plantago & $\mathrm{h}$ & 24 & Europe & Brit: 6 \\
\hline Polypremum & $\mathrm{h}$ & 1 & Carolina & \\
\hline Scoparia & $\mathrm{h}$. & 3 & America & \\
\hline
\end{tabular}

4th. Flowers one-petaled, one-fruited, aboze:

27 Catesbæa

28 Chomelia

29 Embelia

30 Hediotis

31 Hossmannia

32 Ixora

s 1 Carolina

33 Mannettia

34. Mitchella

$\mathrm{s}$

s 1

s \& h 6 Ceylon

s 1

s: 3 India, America

h 1 Mexico

35 Oldenlandia* h 10 America, Cape, \&c.

36 Pavetta

2 India

87 Petesia

¿ Jamaica

38 Sanguisorbat h. 3 Canada

5th. Flowers one-petaled, two-grained, $\$$ beneath.

$\begin{array}{llll}39 \text { Houstonia } & \text { h } & 2 \text { Virginia } \\ 40 \text { Scabrita } & \text { s } & 1 \text { India }\end{array}$

* From the roots of oldenlandia umbellata is extracted that fine permanent red dye, so much admired in the India cottons; and it is said this plant is so valuable in Asia, that it is sold for a guinea a lb. It is called chay root, or East India madder.

+ In sanguisorba officinalis (common wild burnet) are found small red tubercles on the root, which dyers frequently use instead of cochineal; and it is said they are also found on the roots of pimpinella saxifraga, (burnet saxifrage).

$¥$ Two-grained, three-grained, \&c. means, when the capsule is divided into two or three cells, \&c. and a single grain or seed in each. 
No of

Species in

No Genera. Growth. Species. Native of Britain.

6th. Flowers one-petaled, two-grained, above, starred.*

$\begin{array}{lllrlr}41 & \text { Asperula } & \text { h } & 10 & \text { Europe } & \text { Brit. 2 } \\ \text { 42. Crucianella } & \text { h } & 6 & \text { France, Italy } & \\ 43 \text { Diodia } & \text { h } & 1 & \text { Virgina } & \\ 44 \text { Galium } & \text { h } & 26 & \text { Europe } & \text { Brit. 11 } \\ 45 \text { Knoxia } & \text { h } & 1 & \text { Ceylon } & \\ 46 \text { Rubia } & \text { h } & 5 & \text { France, Italy } & \text { Brit. 1 } \\ 47 \text { Scherardia } & \text { h } & 3 & \text { Europe } & \text { Brit. 1 } \\ 48 \text { Siderodendrum } & \text { h } & 1 & \\ 49 \text { Spermacoce } & \text { h } & 8 & \text { Carolina } & \end{array}$

7th. Flowers one-petaled, four-grained, beneath.

50 Siphonanthus $\mathrm{s} \quad 1$ India

8th. Flowers four-petaled, beneath.

$\begin{array}{llrll}51 \text { Ammannia } & \text { h } & 5 & \text { Jamaica } \\ 52 \text { Banksia } & \text { h } & 6 & \text { New Holland } \\ 53 \text { Blackburnia } & \text { h } & 1 & \\ \text { 54 Curtisia } & \mathrm{s} & 1 & \text { Cape } \\ 55 \text { Epimedium } & \text { h } & 1 & \text { Alps } \\ 56 \text { Fagara } & \text { s } & 5 & \text { Jamaica } \\ 57 \text { Hartogia } & \text { s } & 1 & \text { Cape } \\ 58 \text { Monetia } & & 1 & \\ 59 \text { Orixa } & & 1 & \text { Japan } \\ \text { 60 Othera } & \text { s } & 1 & \text { Japan } \\ \text { 61 Ptelea } & \text { s } & 2 & \text { America } \\ \text { 62 Rhacoma } & \text { s } & 1 & \text { Jamaica } \\ \text { 63 Samara } & \text { s } & 1 & \text { E. Indies } \\ \text { 64 Skimmia } & & 1 & \text { Japan }\end{array}$

* These are the plantce stellate of Ray, having two naked seeds, and the leaves disposed round the stem in the form of a radiant star; and are held to be diuretic. There are several other starry plants than those above mentioned, which may be seen in the order stellate, of the Fragments of a Natural Method; viz. Phyllis, Richardia,valentia, anthospermum, hedyotis, lippa, ophiorhiza, spigelia, houstonia, oldenlandia, coffea, psychotria, cornus, ixora, pavetta. 
No Genera. Growth. Species. Native of $\quad \begin{gathered}\text { Species in } \\ \text { Britais? }\end{gathered}$

9th. Flowers four-petaled, above.

65 Cissus

66 Cornus*

67 Embothrium

68 Ludwigia

69 Santalum

70 Trapa $\mathrm{s} \quad 6$ India

t \& h 9 Virginia, Canada Brit. $\mathrm{t}$

h 4 N. Caledonia, N. Hollaud

h 3 Virginia

$\mathrm{t} I$ India

h 2 Europe

10th. Flowers incomplete, beneat\%.

\begin{tabular}{|c|c|c|c|c|}
\hline 71 Alchemilla & h & 4 & Sweden & Brit. \\
\hline 72 Camphorosma & $\mathbf{s}$ & 5 & Spain, Italy & \\
\hline 73 Cometes & $\mathrm{h}$ & 1 & Surat & \\
\hline 74. Dorstenia & h & 4 & America & \\
\hline 75 Krameria & $\mathrm{s}$ & 1 & & \\
\hline 76 Louichea & h & 1 & & \\
\hline 77 Nigrina & & 1 & Japan & \\
\hline 78 Rivina & $\mathrm{s}$ & 4 & W. Indies & \\
\hline 79 Salvadora & $\mathrm{s}$ & 1 & Persian Gult & \\
\hline 80 Struthiola & s & 3 & Cape & \\
\hline
\end{tabular}

11th. Flowers incomplete, above.

\begin{tabular}{|c|c|c|c|}
\hline 81 Âcæna & s & 1 & Mexico \\
\hline 82 Elæagnus & $\mathrm{s}$ & 9 & Spain, Japar \\
\hline 83 Gonocarpus & & 1 & Japan \\
\hline 84. Isnardia & h & 1 & China, America \\
\hline 85 Sirium & s & 1 & \\
\hline
\end{tabular}

* The berries of the cornus sanguirea, when ripe, and laid in a heap to soften and heat a little, and the pulp then pressed, will yield an oil of a clear green colour, without smell or taste, and when mixed with sallad, cannot be distinguished from the best olive oil: when spread upon the surface of water, and exposed to the air for a month, it becomes a solid consistence, and of a white colour like wax, and with a wick, will burn with a white flame, without any sensible smell or smoke.

L' Hèritier in his description of the genưs cornus, (printed at Paris, 1788) makes eleven species.-He leaves out the japonica of Linnæus, and adds three others lately found in America, viz. circinata, stricta, paniculata.-He says the cornus florida hath a febrifuge quality, and its decoction is not inferior to the cinctrone. officinalis, and the cornus mascula is the cornelian cherry; which some persons are fond of eating, as having an agreeable acid. 


\section{ORDER II. DIGYNIA.}

(TWO FEMALES.)

\begin{tabular}{|c|c|c|c|c|}
\hline Genera. & Growth. & $\begin{array}{l}\text { No of } \\
\text { Species. }\end{array}$ & s. Native of & $\begin{array}{l}\text { Species in } \\
\text { Britain. }\end{array}$ \\
\hline 86 Alphanes & h & 1 & & Brit. 1 \\
\hline 87 Bufonia & $\mathrm{h}$ & 1 & & Brit. 1 \\
\hline 8s Cruzita & & 1 & Spain, America & \\
\hline 89 Cuscuta* & h & 3 & Virginia, Europe & Brit. 1 \\
\hline 90 Galopina & & ] & & \\
\hline 91 Gomozia & & 1 & Granada & \\
\hline 92 Hamamelis & $\mathrm{s}$ & 1 & Virginia & \\
\hline 3 Hypecoum & $\mathrm{h}$ & 3 & Archipelago & \\
\hline 94. Nertera & h & 1 & & \\
\hline
\end{tabular}

\section{ORDER III. TETRAGYNIA.}

\section{(FOUR FEMALES.)}

\begin{tabular}{|c|c|c|c|c|}
\hline 95 Coldenia & h & 1 & India & \\
\hline 96 Ilext & $t$ & 10 & Asia & Brit. \\
\hline 97 Myginda & 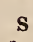 & 1 & America & \\
\hline 98 Potamogeton & h & 12 & Europe & Brit. 12 \\
\hline 99 Ruppia & h & 1 & Sea-side & \\
\hline 00 Sagina & $\mathbf{h}$ & 4 & Europe, Virginia & Brit. \\
\hline 1 Tillæa & & 4 & Europe & Brit. \\
\hline
\end{tabular}

* Cuscuta (dodder) is a parasitical plant, for it decays at the root, and is afterwards nourished by the plant that supports it: it will frequently twine round a thistle. It's spirals turn contrary to the motion of the sun; it bears no leaves, except a few small membraneous scales.

+ Ilex is very variable in the parts of fructification, and hath many varieties. 


\title{
CLASS V. PENTANDRIA.
}

\author{
(FIVE STAMINA OR MALES.)
}

Containing six orders.

\author{
ORDER I. MONOGYNIA.** \\ (ONE FEMALE.)
}
No of
No Genera, Growth. Species. Native of
Species in Britain.
1st. Flowers one-petaled, beneath, one-seeded.

1 Mirabilis

2 Plumbago

3 Weigela

4. Xystris h 3 Mexico

h 4 Spain, Italy, Zeylon

1 Japan

s $\quad 1$

- 2d. Flowers one-petaled, beneath, two-seeded. Rough-leaved.

5 Cerinthe h 2 Europe

6 Messerschimidia s \&h 2 Dauria

3d. Flowers one-petaled, beneath, four-seeded. Rough-leaved.

7 Anchusa

8 Asperugo

9 Borago

10 Cynoglossum

11 Echium

12 Heliotropium h 8 America

h 2 Egypt

h 5 Africa, India

h 14 Virginia, Peru

s \& h 16 Italy, \&xc.

s \& h 17 Europe, India, Peru
Brit. 1

Brit. 1

Brit. 1

Brit. 1

Brit. 2

* The berries of the monopetalous plants of this first order, are for the most part poisonous.-The rough-leaved plants are said to be glutinous and vulnerary: they are the asperifolive of Ray, having four naked seeds. 
No Genera. Growth species. Native of

Species in Britain,

13 Lithospermum h. 13 Europe, Peru

14. Lycopsis

h 7 Virginia, Egypt

15 Myosotis h\&s 9 Virginia, Peru

Bit. 3

16 Onosma

h 3 Sibe:ia, India

17 Pulmonaria* h 6 Siberia

18 Symphytum ' h 3 India

Brit. I

Brit. I

Brit. 2

Brit. 2

4th. Flowers one-petaled, beneath, five-seeded.
19 Nolana
h
5 Peru

5th. Flowers one-pctaled, beneath, seed-covered.

Capsules.

20 Allamanda

21 Anagallis

22 Androsace

23 Aretia

24. Azalea

2.5 Brossæa

26 Chironia

27 Convolvulust

28 Coris

29 Cortusa

30 Cyclamen $\ddagger$

31 Daturaई

32 Diapensia

$\begin{array}{rrll}\text { h } & 1 & \text { Surinam } & \\ \text { h } & 6 & \text { Europe, Peru } & \text { rit. } 2 \\ \text { h } & 6 & \text { Austria } & \\ \text { s } & 3 & \text { Swiss, Alps } & \\ \text { s } & 6 & \text { India, Lapland } & \text { Brit. 1 } \\ \text { s } & 1 & \text { America } & \\ \text { s } & 10 & \text { Cape } & \\ \text { h } & 68 & \text { W. Indies, Peru, \&c. } & \text { Brit. 3 } \\ \text { h } & 1 & \text { Europe } & \\ \text { h } & \text { \& } & \text { Alps } & \\ \text { h } & 4 & \text { Europe, India } & \\ \text { h } & 8 & \text { China, Peru } & \text { Brit. 1 } \\ \text { h } & 1 & \text { Lapland } & \end{array}$

* Pulmonaria officiannlis (common spotted lungwort, or Jerusalem cowslip) with white spots distinct, on dark green leaves; with flowers in small bunches on the top of the stalks. - Pulmonaria paniculata, with flowers panicled, and confluent spots.

+ Convolvulus jalapa (jalap) receives its name from Jalapa, a town in New Spain in South America, where it was first discovered - Convolvulus scammonia (scammony) is also a cathartic, and much of the same nature as jalap, but rather stronger. The cornbind that is so very troublesome a weed in gardens and the fields, and pehetrates so very deep into the ground, is the smaller corntind, convolvulus arvensis.

$\ddagger$ See note to arachis.

\$ Datura (thorn apple) is narcotic, and dangerous to be taken inwardly, but a cataplasm of its leaves and seeds are ccmmender for burns. 


\begin{tabular}{|c|c|c|c|c|c|}
\hline No & Genera. & Growth. & $\begin{array}{l}\text { No of } \\
\text { species. }\end{array}$ & Native of & $\begin{array}{c}\text { Species in } \\
\text { Britain. }\end{array}$ \\
\hline 3 & Dodecatheon* & $\mathrm{h}$ & 1 & Virginia & \\
\hline 4 & Dorœna & & 1 & Japan & \\
\hline & Epacris & $\mathrm{h}$ & 3 & New Zealand & \\
\hline 30 & Galax & h & 1 & Virginia & \\
\hline & Geniostoma & $\mathrm{h}$ & 1 & & \\
\hline 88 & Hott & h & 2 & India & Brit. 1 \\
\hline 30 & Hydrophillum & $\mathrm{h}$ & 2 & Virginia, Canada & \\
\hline to & Hyoscyamus $\uparrow$ & $\mathrm{h}$ & 7 & Syria & Brit. 1 \\
\hline 4 & Ipomoea & h & 28 & E. \& W. Indies, Peru & \\
\hline & Lisianthus & $\mathrm{s}$ & 9 & Jamaica, Peru & \\
\hline & Lysimachia & h & 10 & Levant, Japan & Brit. \\
\hline & Menyanthes $\ddagger$ & $\mathrm{h}$ & 4 & Ceylon, & Brit. \\
\hline & Nicotiana & $h \& s$ & 10 & America, Pe & \\
\hline( & Ophiorhiza & h & 2 & E. Indies, America & \\
\hline & Oribasia & h & 1 & & \\
\hline & Patagonula & $\mathrm{s}$ & 1 & Ámeric & \\
\hline & Phl & h & 11 & America, Peru & \\
\hline & Pora & $\mathrm{s}$ & 1 & E. Indies & \\
\hline & onium & $\mathrm{h}$ & 5 & America & Brit. \\
\hline & ula | & h & 13 & $\mathrm{Eu}$ & Brit. 3 \\
\hline
\end{tabular}

* In the beautiful flower of the dodecathean meadia, the pistil is very long, and the stamens are very short, hence the necessity of the flower hanging down, that the farina may fall on the stigma; but when the seeds are formed, the flower-stalks erect themselves to retain the seed.-In the same manner the crown-imperial, the dog-tooth violet, and several others, whose pistils are longer than the stamens, hang down their heads till the seed is formed, and then erect themselves. See note to bractece, page 33 .

+The roots of hyoscyamus niger (black henbane) are used for anodine necklaces; and in the leaf and stem exists a narcotic quality like opium, but not in the seeds.

Phytologia.

$¥$ Bucklean, boglean, or bogbane (menyanthes trifoliata) is said to be a sovereign remedy for the rheumatism, if made into tea in a morning, and rather above half a pint warmed and drank every night, at going to bed.

Universal Museum, for June 1766.

\$ Nicotiana tabucum (tobacco) received the name of nicotiana in honour of M. Nicot, who introduced it to the Queen of Portugal.-See the number of seeds in a tobacco plant, under the word semina, one of the parts of the fructification.

II Primula veris hath three varieties, viz. primula veris officinalis (cowslip) primula veris elatior (oxslips and polyanthus) and primula veris acaulis, (common primrose). In this genus primula, the stamina are very short, fixed in the tube of the corol; and are sometimes placed near the bottom of the tube, and sometimes 
$\mathrm{N}^{\circ}$ of

No Genera.

Growth. species.

Native of

Species ins

53 Retzia

54. Sheffieldia

$\begin{array}{rrl}\text { s } & 1 & \text { Cape } \\ \text { h } & 1 & \\ \text { h } & 1 & \text { Alps } \\ \text { h } & 2 & \text { Marylard } \\ \text { h } & 1 & \\ \text { s } & 1 & \text { America } \\ \text { h } & 1 \mathscr{L} & \text { Italy, Phenicia } \\ \text { h } & 1 & \end{array}$

Britain.

5j Soldanella

56 Spigelia

57 Stephanium

58 Theophrasta

59 Verbascum

60 Uncaria

\section{Follicles.**}

61 Cameraria

62 Ceropegia

$s 2 \mathrm{~W}$. Indies

63 Echites

64. Nerium

65 Plumeria

h. 4 Malabar

$\mathrm{s} 21 \mathrm{~W}$. Indies, Peru, Jamaica

h 10 Ceylon, Peru

66 Tabernæmontana s

4. W. Indies

67 Vinca

s \& h 5 Madagascar

Brit. 2

Berries.

68 Arduina

69 Atropa

7) Bassovia

71 Bertiera

72 Bladhia

73 Blunsfelsia

74. Camax

$\begin{array}{crr}\mathrm{s} & 1 & \text { Cape } \\ \mathrm{s} \& \mathrm{~h} & 10 & \text { Europ }\end{array}$

\& h 10 Europe, Peru

Brit.

75 Capsicumt h\&s 7 E. \& W. Indies, Peru

Brit. 5

h 1

h 1

3. Japan, \&c.

s. 1 Anerica

ly 1

75 Capsicumt he s 7 E. \& W. Indies, Peru

near the top; when placed near the bottom, the style of the pistillum, with its stigma, rises without interruption between the stamina, so as to be equal with the mouth of the tube, and sometimes higher; this by florists is called pin-eyed, and considered as an imperfection; but when the stamina are placed near the top of the tube, they become even with the mouth, and in this case the style is kept low

- by the stamina filling the mouth of the tube; this is called thrum-eyed, and add's to the perfection of the flower.

* See follicle under pericarpium; as also berry and drupe.

+ Capsicum annuum (Guinea pepper) hath many varieties.-In Ceylon they have a red pepper called chilly, which it is said makes cayenne, or Kiang pepper.-But it was lately asserted in a newspaper, that the composition generally sold as cayenne pepper, consisted of four tenths red lead, three tenths salt, and three tenths cayenne pepper; if this is fact, it must be very prejudicial to health. See note to cayenne pepper in index. 


\begin{tabular}{|c|c|c|c|c|c|}
\hline$N^{\circ}$ & Genera. & Growth. & $\begin{array}{l}\text { No of } \\
\text { species }\end{array}$ & Native of & $\begin{array}{l}\text { Species in } \\
\text { Britain. }\end{array}$ \\
\hline 76 & Carissa & $\mathrm{s}$ & 2 & India & \\
\hline 77 & Cerbera & $\mathrm{s}$ & 3 & Brazils & \\
\hline 73 & Cestrum & $\mathrm{s}$ & 11. & W. Indies, Peru & \\
\hline 79 & Chrysophyllum & $\mathrm{m}: \mathrm{t}$ & 3 & W. Indies & \\
\hline 80 & Cordia & $\mathrm{s}$ & 6 & W. Indies & \\
\hline 81 & Cryptostomim & $\mathrm{n} \mathrm{h}$ & 1 & & \\
\hline 82 & Ehretia & $\mathrm{t}$ & 4 & W. Indies & \\
\hline 83 & Ellisia & h & 1 & Virginia & t \\
\hline 84 & Fagraa & & 1 & Zeylon & \\
\hline 85 & Gynopogon & $\mathrm{s}$ & 1 & & \\
\hline 86 & Jacquinia & s \& h & 3 & America & \\
\hline 87 & Laugeria & $\mathrm{s}$ & 3 & America, Pert & \\
\hline 88 & Lightfootia & h & 3 & & \\
\hline 89 & Lycium & s & 16 & Spain, Africa, Pert & \\
\hline 90 & Menais & s & 1 & America & \\
\hline 91 & Myrsine & s & 1 & Africa & \\
\hline 92 & Paderia & $\mathrm{s}$ & 1 & India & \\
\hline 93 & Physalis* & h & 14 & Spain, Peru & \\
\hline 94. & Randia & s & 4 & America, Peru & \\
\hline 95 & Rauvolfia & $\mathrm{s}$ & 5 & W. Indies, Peru & \\
\hline 96 & Schwenkfeldia & $a \mathrm{~s}$ & 1 & & \\
\hline 97 & Sideroxilon & $\mathrm{t}$ & 9 & Ethiopia & \\
\hline 98 & Solanum & h \& s & 85 & America, Peru, \&c. & Brit. \\
\hline 99 & Strychnost & $\mathrm{t}$ & 4 & India, Peru & tr \\
\hline 100 & Toumefortia & s \& h & 13 & W. Indies, Peru & \\
\hline 01 & Varronia & $\mathrm{s}$ & 6 & America & \\
\hline
\end{tabular}

* Physalis alkehengi (common winter cherry) is good against suppression of urine, and for promoting the expulsion of gravel ; - five or six, or more of the cherries may be taken at a time.

$\uparrow$ The fruit of the egg-plant (solunum melongena) broiled and eaten with pepper and salt, is held to be very delicious at Batavia. (Cook's Voyage). Solanum tuberosum is the common potatoe, of which there is a variety that produces potatoes on the stem, in the air, as well as under-ground; like the magical onion. In Barbadoes, \&c. they make a drink from the potatoe root, called molby.

\# The seeds or nuts of the strychnos nux-vomica are used here to kill rats, and in the East Indies they are used in the distillation of the country spirits, to render them more intoxicating.-And the strychnos potatorum is used to clear muddy water, by rubbing the inside of the vessel with one of the nuts for a minute or two, and the impurity will soon subside; they are sold in the market for this purpose, and are cons ntly carried about by the soldiers in time of war; they are easier to be had than alum, and probably less hurtful. 


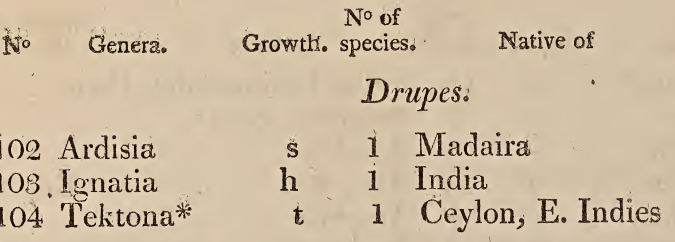

6th. Flowers one-petaled, above.

Capsules.

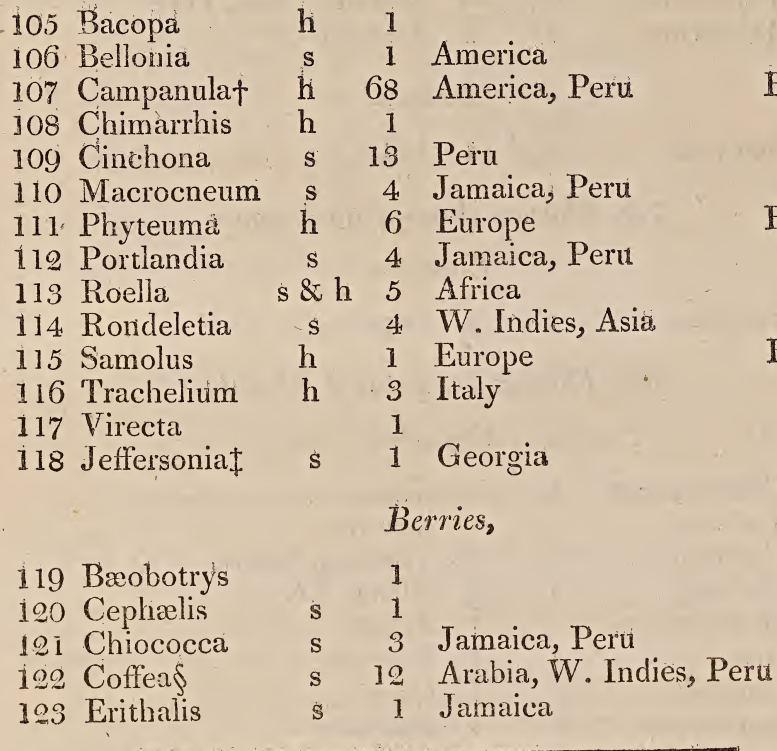

Brit. 8

Brit. 1

Brit. 1

116 Trachelium

117 Virecta

118 Jeffersonia 


\begin{tabular}{|c|c|c|c|c|c|}
\hline No & Genera. & Growth. & $\begin{array}{l}\text { No of } \\
\text { species. }\end{array}$ & Native of & $\begin{array}{l}\text { Species in } \\
\text { Britain. }\end{array}$ \\
\hline 124 & Gardenia* & $\mathrm{s}$ & 11 & India, Coromandel, Peru & \\
\hline 125 & Genipa & $\mathrm{s}$ & 2 & America, Peru & \\
\hline 126 & Hamellia & $\mathrm{s}$ & 1 & America & \\
\hline 127 & Lonicera & g & 16 & Alps, \&ic. & Brit. 1 \\
\hline 128 & Matthiola & $\mathrm{s}$ & 1 & America & \\
\hline 129 & Morinda & s \& $h$ & 3 & America & \\
\hline 130 & Mussæenda & $\mathrm{s}$ & 2 & India & \\
\hline 131 & Plocama & $\mathrm{s}$ & 1 & Canary Islands & \\
\hline 132 & Psychotriat & $\mathrm{h}$ & 30 & Jamaica, Asia, Perv & \\
\hline 133 & Triosteum & h & 2 & America & \\
\hline
\end{tabular}

\section{Drupes.}

134. Scævola \& 1 India

7th. Flowers three-petaled, above。

Capsules.

135 Strelitzia $\$ 1$ Cape

8th. Flowers five-petaled, beneats.

Capsules.

$\begin{array}{llrl}136 \text { Calodendram } & \text { t } & 1 & \text { Cape } \\ 137 \text { Cedrelaf } & \text { s } & 1 & \text { America } \\ 138 \text { Claytonia } & \text { s } & 3 & \text { Virginia, Siberia } \\ 139 \text { Diosma } & \text { s } & 18 & \text { Africa, \&c. } \\ 140 \text { Hovenia } & & 1 & \text { Japan } \\ 141 \text { Itea } & \text { s } & 1 & \text { Virginia } \\ 142 \text { Roridula } & \text { s } & 1 & \text { Cape } \\ 143 \text { Sauvagesia } & \text { h } & 1 & \text { Jamaica }\end{array}$

* Gardenia thunbergia (the wild Cape jasmine) when in full flower, gives out so powerful a scent, that, in an evening, it may be felt for some miles.

+ Ipecacuanha is the root of phychotria emetica, of which there are two sorts, the Peruvian and the Brazilian, both of a brownish colour, but the first is said to be the best. There is also a white kind, which hath sometimes been imported, but is of a base sort, and hath not the same effects as the others.

$¥$ This genus cedrela is very similar to swietenia.

§This genus diosma is various in sex, nectaries, and capsules. 


No Genera, Growth, species. Native of $\begin{gathered}\text { Species in } \\ \text { Britain. }\end{gathered}$

\section{Berries.}

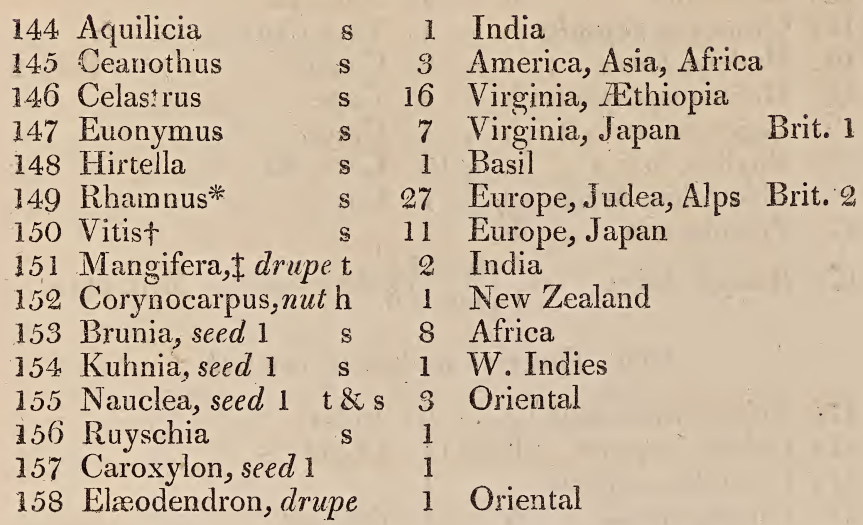

\section{9th. Flowers five-petaled, above.}
159 Argophillum
160 Carpodctus
h 1 New Caledonia
161 Conocarpus, seed $1 \mathrm{~s}$
3 W. Indies

* From the berries of the common buckthorn (rhamnus catharticus) is made a wery fine green colour, called by the French, verd-de-vessie, much esteemed by miniature painters.-Rhamnus theezans is used by the lower people in China instead of tea. - The fruit of the rhamnus zizyphus, (Jujube tree) in France and Italy, furnish part of the winter dessert for the table.

+ Each corol of the vine (vitis vinifera) consists of five green petals, (appearing like a bud) which does not open at the top like other corols; but becomes detached at the base by the forcible advance of the stamina, and rises up along with them like a little hood or cowl, and then drops off, and the stamina expand themselves. Foreign currans or currants, or more properly Corinths, because they were chiefly cultivated about Corinth, are a very small sweet high-flavoured black or purple grape, generally without stones, (being a variety of the vitis vinifera) they are picked from the stalks and dried in the sun, and we have them now chiefly from Zante, an island in the Mediterranean sea, about twenty-four miles in length and twelve in breadth, and in common years is said to produce between nine and ten millions of pounds.

$¥$ Mangifera indica (the mango tree) is inserted in this class, although in reality it is polygamous, and hitherto very imperfectly described; the Indian curry (a spicy powder) is not only obtained from the fruit of this tree, but they have curries made of fish, fowl, or the flesh of mutton and goat.

Boyd's Embassy to the King of Candy, in 1782. 
No. Genera. Growth. species. Native of $\begin{gathered}\text { No of } \\ \text { Britain. }\end{gathered}$

162 Cyrilla, capsules s 1 Carolina

163 Escallonia h 1 America

164. Gronovia, capsules h 1 Vera Crux

165 Hedera, berry s 2 Canada

166 Heliconia, capsules h 4 Cape

167 Lagoecia, seeds 2 h 1 Crete

168 Phylica, berry s 12 Cape, \&c.

169 Plectronia, berry \& 1 Cape

170 Portulacaria h 1

171 Ribes, * berry $\quad\left\{\begin{array}{l}\text { curr. } \\ \text { goos. }\end{array}\right\} 6$ America Brit. curr. 3

10th. Flowers incomplete, beneath.

\section{Achyranthes, seed $1 \mathrm{~s}$}

173 Celosia, capsule h

174. Chenolea, capsule

175 Glaux, capsule h 1 Sea-side Brit. 1

$\begin{array}{lllll}176 & \text { Hedycrea, drupe } & \mathrm{s} & 1 & \\ 177 & \text { Illecebrum, caps, s } \& \text { h } & 19 & \text { E. Indies, Canada Brit. } 1\end{array}$

11 th. Flowers incomplete, above.

178 Thesium, seed 1 h 17 Alps, \&c.

Brit. 1

\section{ORDER II. DIGYNIA. \\ (TWO FEMALES)}

1st. Flowers one-petaled, beneath.

$\begin{array}{llll}179 \text { Melodinus, berry } & \text { s } & 1 & \text { New Caledonia } \\ 180 \text { Rochefortia } & & 1 & \\ 181 \text { Schrebera } & \text { s } & 1 & \text { Cape } \\ \text { 182 Steris, berry } & \text { s } & 1 & \text { Java }\end{array}$

* Riles inerme (unarmed) are currants, of which there are four species; and ribes aculeata (prickly) are gooseberries, of which there are six species.

N. B. Linnæus makes ribes of the neuter gender, when it refers to currants; and of the feminine gender, when it relates to gooseberries. 


No of
Nenera. Growth. species. Native of $\quad \begin{gathered}\text { Species in } \\ \text { Britain. }\end{gathered}$

\section{Follicles*.}

$\begin{array}{lcrl}183 \text { Apocynum } & \text { s \& h } & 9 & \text { N. America, Siberia } \\ 184 \text { Asclepias } & \text { h } & 27 & \text { France, Spain, \&c. } \\ 185 \text { Cynanchum } & \text { h } & 15 & \text { Spain, Cape, \&c. } \\ 186 \text { Pergularia } & \text { s } & 2 & \text { India, Japan } \\ 187 \text { Periplocat } & \text { s } & 5 & \text { India, Africa } \\ 188 \text { Stapeliag } & \text { h } & 5 & \text { Cape }\end{array}$

Capsules.

189 Cressa
190 Dichondra
191 Gentiana\|l
192 Hydrolea
193 Swertia

$\begin{array}{lrll}\text { h } & 1 & \text { Crete } & \\ \text { h } & 1 & & \\ \text { h } & 39 & \text { Pirenean, \&c. } & \text { Brit. } 5 \\ \text { h } & 1 & \text { America } & \\ \text { h } & 6 & \text { Siberia } & \text { Brit. } 1\end{array}$

* See follicle under pericarpizum,

+ Apocynum androscemifolium is called the calchfly apocynum, or dogs-lane, from its power in catching small flies by the converging of the anthers, and is thus in part described by Linnæus; it hath a nectarium with five corpuscules, glandular, oval, surrounding the germen; filaments five, very short ; anthers five, oblong, erect, acute, two-cleft at the base, converging.-And as there are interstices at the bottom, between the short filaments, to give air to the nectarium, when a fly inserts its proboscis through those interstices to plunder the honey, in drawing it out it often gets between the forcible converging of the anthers, and in struggling up. wards gets the faster entangled, as the anthers seem to converge gradually closer towards the top, and having sharp edges on the sides, prevent a return, and generally hold the fly till it dies; but if it is so fortunate as to make its escape, which is sometimes the case, it is probably by descending its proboscis to the place where it entered: sometimes the fly is caught by a leg.

$\ddagger$ Periploca is from the Greek, and means round embracing.

§Stapelia hirsuta (African swallow-wort) hath a foted odour so very like carrion, that the common flesh fly deposits its eggs on it, which are frequently hatched, but the maggots wanting proper food, die soon after. (See note to arum.) Mr. Masson, who hath been twice sent out to the Cape of Good Hope to collect various plants for the botanic garden at Kew, hath collected about forty species of the stapelia, ten of which he hath published (in 1796) with accurate plates and de. scriptions; and he purposes that the rest should follow in decades.

\| The species in gentiana greatly vary in the clefts of the corcl; and according to Dioscorides obtained its name from Gentius a king of Illyria, who discovered its virtues: though sometimes the ranunculus thora hath been substituted for, or hath happened to be mixed with the gentian, as having a similar root, but hath had bad effects from it being a poisonous plant; it is known by being a darker colour on the outside, and not so yellow within. 
No Genera. Growth. $\begin{gathered}\text { No of } \\ \text { species. Native of } \quad \begin{array}{c}\text { Species in } \\ \text { Britain. }\end{array}\end{gathered}$

2d. Flowers five-petaled, above.

194 Russelia

195 Staavia

196 Vahlia

$\begin{array}{lll} & 1 & \text { Cape } \\ \text { h } & 1 & \\ \text { h } & 1 & \text { Cape }\end{array}$

3d. Flowers five-petaled, beneath.

Capsules.

$\begin{array}{llll}197 \text { Anabasis, berry } & \text { s \& h } & 4 & \text { Spain } \\ 198 \text { Bumalda } & & \text { 1 } & \text { Japan } \\ 199 \text { Coprosma } & & 2 & \text { New Zealand } \\ \text { 200 Heuchera } & \text { h } & 2 & \text { America } \\ \text { 201 Linconia } & \text { s } & \text { 1 } & \text { Cape } \\ \text { 202 Nama } & \text { h } & \text { 2 } & \text { Ceylon, Jamaica } \\ \text { 203 Velezia } & \text { h } & \text { 1 } & \text { Europe }\end{array}$

4th. Flowers incomplete.

\begin{tabular}{|c|c|c|c|c|}
\hline 204 Beta & h & 3 & France, Germany & Brit. I \\
\hline 205 Bosea & $\mathrm{s}$ & 1 & Canaries & \\
\hline 06 Chenopodium* & $\mathrm{s} \& \mathrm{~h}$ & 20 & Europe & Brit. 9 \\
\hline 07 Gomphrena & $\mathrm{h}$ & 8 & India, Brasil & \\
\hline 88 Herniaria & s \& h & 4 & Spain & Brit. \\
\hline 9 Microtea & $\mathrm{h}$ & 1. & & \\
\hline Salsola & $\mathrm{s} \& \mathrm{~h}$ & 16 & Europe & \\
\hline Ulmus & $\mathrm{t}$ & 6 & America & bi \\
\hline
\end{tabular}

5th. Flowers five-petaled, above, two-seeded, umbelled.†

A. With an universal and partial involucre.

$\begin{array}{lllll}212 & \text { Astrantia } & \mathrm{h} & 5 & \text { Alps } \\ \text { 213 Danaa } & \mathrm{h} & \mathrm{j} & & \\ \text { 214 Eryngium } & \mathrm{h} & 9 & \text { Alps } & \text { Brit. 2 }\end{array}$

* Chenopodium-see atriplex.

$\uparrow$ These are the umbellate plants of Tournefort; and it is observed, that in dry soils they are aromatic, warm, resolvent, and carminative; but in moist places frequently poisonous. The virtue is in the roots and seeds. - Note, panax and arctopus (though umbelled) are placed in the class and order polygamia, diocia, as having the character of that class and order, though they have only five stamina. There are also a few other umbelled plants placed in different classes, as allium, opercularia, \&c. 


\begin{tabular}{|c|c|c|c|c|}
\hline Genera. & Growth & $\begin{array}{l}\text { No of } \\
\text { species. }\end{array}$ & Native of & $\begin{array}{l}\text { Species in } \\
\text { Britain. }\end{array}$ \\
\hline Hud & h & 13 & America, China & Brit. 1 \\
\hline $6 \mathrm{Ph}$ & . & 1 & Can & \\
\hline 7 Sani & h & 3 & Canada, Maryland & Brit. 1 \\
\hline 8 Spananthe & h & 1 & & \\
\hline
\end{tabular}

Flowers radiate; ${ }^{*}$ florets of the disc abortive.

219 Artedia

220 Caucalis

221 Daucus

h 1 Libanus

h 6 Europe

Brit. 2

222 Echinophora

h 17 India

Brit. 1

223 Heracleum

h 2 Apulia

Brit. 1.

h 7 Siberia, Alps

Brit. 2

Flowers radiate; florets of the radius abortive.

224. Oenanthet

h 5 Europe

Brit. 3

Flowers radiate, all fertile.

225. Tordylium,

h 7 Syria, Crete

Brit. 3

Flowers flosculous; $\$$ florets of the disc abortive.

226 Laserpitium h 14 Europe

227 Peucedanum h 9 Alps, Japan

Brit. 2

Flowers flosculous, all fertile.

228 Ammi

229 Angelica

230 Anthamanta

231 Bubon

232 Bunium

233 Bupleurum

234 Cachrys

235 Conium h 3 Europe

h 5 Archangel Brit. 1

h 9 Sicily, Crete, China Brit. 1

s \& h 4 Macedonia

h 1 Brit. 1

s \& h 17 Ethiopia Brit. 2

h 3 Sicily

h 4. Africa

Brit. 1

* See radiate flowers explained in a note under the head of distinction of flowers.

+ Oenanthe crocata (water drop-wort) is one of the strongest vegetable poisons that is known.-See laurel, cherry, in index.

+ See flosculous explained in observation to the head of the class syngenesia. 


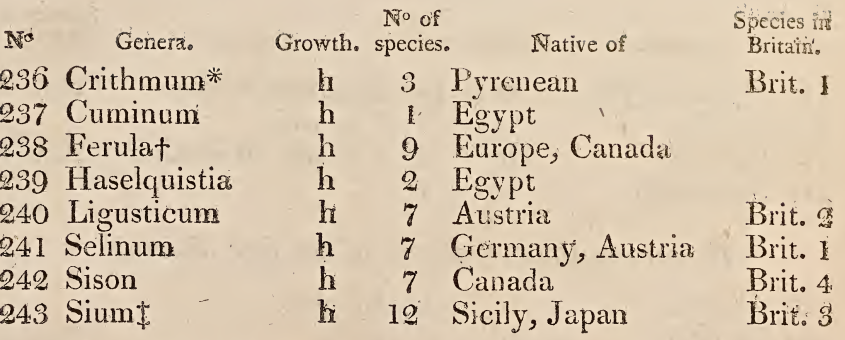

B. Witt only partial involucres; no universal.

Flowers subradiate; all fertile.

244. Ethusa

h 3 Europe

Brit. 2

Flowers radiate; florets of the disc abortive.

245 Coriandrum

246 Seandix

$\begin{array}{ccl}\text { k. } & 2 & \text { Italy } \\ \text { h } & \text { io } & \text { Europe }\end{array}$

Brit. i

Brit. 4

Flowers flosculous, all fertile.

$\begin{array}{llrll}247 \text { Cicuta } & \text { h } & 3 & \text { Canada } & \text { Brit. 1 } \\ 248 \text { Imperatoria } & \text { h } & 1 & \text { Alps } & \text { Brit. I } \\ 249 \text { Phellandrium } & \text { h } & 2 & \text { Europe } & \text { Brit. I } \\ \text { 250 Seseli } & \text { h } & 11 & \text { Europe } & \end{array}$

Flowers flosculous; florets of the disc abortive.

251 Chærophyllum s \& h 10 Europe

Brit.

c. With no involucre; neither universal nor partial. Flowers flosculous; florets of the disc abortive.

252 Carum

h $\quad 1$ Europe

h 5 Egypt

Brit. 1

253 Smyrnium

$$
\text { h } 5 \text { Egpt }
$$

Brit.

* The samphire used as a pickle is the British species (crithmum maritimaim) and grows in the crevices of rocks by the sea-side; which is said to be a very wholesume and agreeable pickle; but the markets are too often supplied with a spurious surt, called goiden samphire, (inula crithmifolia).

+ The drug of asafoetida is a gum resin of ferula asafotida. Ferula communis (giant fennel) grows plentifully in the kingdom of Naples, and is said to rise to the: hight of twelve feet.

¿ium nodiflorum (creeping water parsnep).-See note to sisymbrium. 
No Genera. Growth. Species, Native of $\quad \begin{gathered}\text { No of } \\ \text { Britain. }\end{gathered}$

Flowers flosculous, all fertile.

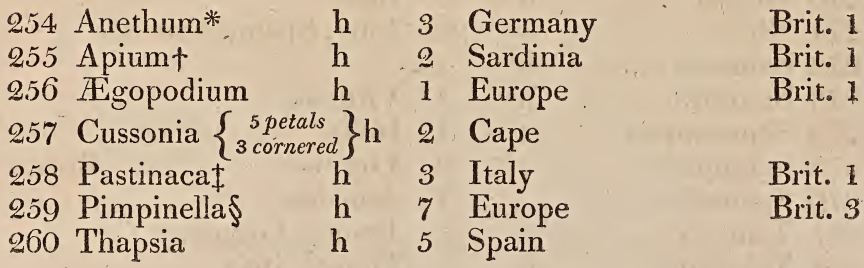

\section{ORDER III. TRIGYNIA.}

\section{(THREE FEMALES.)}

1st. Flowers above, five-cleft.

261 Sambucus 262 Viburnum t \& h 6 Canada

s 19 Spain, America
Brit. 2

Brit. 2

\section{2d. Flowers beneath.}

263 Basella

264. Pharnaceum

265 Reichelia

266 Xylophylla\| h 3 India

h 13 Asia, Africa

h 1

2

Corols five-petaled.
267 Alsine 9
h 3 France
Brit. 1
268 Cassine
s 3 Ethiopia, Cape, Carolina

* Anethum (fennel and dill). Note, fennel only differs from dill, in the seeds not being bordered at the edge like those of dill.

+ Selery (a species of apium) called apium dulce by other authors, not described by Linnæus, being only a variety from apium graveolens: The universal involucre is often wanting.

$¥$ The gum resin called opoponax, is from the pastinaca opoponax.

$\S$ Aniseeds are from a species of pimpinella (pimpinella anisum).

\|Dr. Sims thinks there is no difference between the genus xylophylla and phyllanthus; and that they ought to be placed in the class and order monocia, monadelphia.

II In alsine media (the common chickweed) the stamina soon fall off, so that the flowers frequently appear with fewer than five. The young shoots and leaves, when boiled, are said to be very like spring spinach, and equally wholesome. 


\begin{tabular}{|c|c|c|c|c|}
\hline Genera. & Growth. & $\begin{array}{l}\text { No of } \\
\text { Specie }\end{array}$ & Native of & $\begin{array}{c}\text { Species it } \\
\text { Britaif. }\end{array}$ \\
\hline 269 Corrigiola & $\mathrm{h}$ & 1 & France. & \\
\hline 270 Drypis & $\mathrm{h}$ & 1 & Italy & , \\
\hline 271 Rhus* & $\mathrm{s}$ & 26 & Italy, Spain, Americe & \\
\hline 272 Salmasia & h & 1 & & \\
\hline 273 Sarothra & h & 1 & Virginia & \\
\hline 274 Semecarpus $\uparrow$ & $\mathrm{t}$ & 1 & India & \\
\hline 275 Staphylea & $\mathrm{s}$ & 2 & Virginia & Brit. I \\
\hline 276 Spathelia & & 1 & Jamaica & \\
\hline 277 Tamarix & $s$ & 2 & France, Germany & \\
\hline 278 Telephium & $\mathrm{h}$ & 2 & France, Italy & \\
\hline 279 Turnera & s & 5 & Jamaica & \\
\hline
\end{tabular}

\section{ORDER IV. TETRAGYNIA.}

(FOUR FEMALES.)

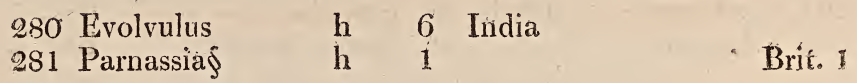

\section{ORDER V. PENTAGYNIA. \\ (FIVE FEMALES.) \\ 1st. Flowers above.}

$\begin{array}{lllll}282 & \text { Aralia } & \text { s \& h } & 7 & \text { China } \\ \text { 283 Commersonia } & \text { h } & 1 & \text { Taheita } \\ \text { 284. Glossopetalum } & \text { s } & 1 & \end{array}$

2nd. Flowers beneath.

285 Crassula

286 Gisekia 287 Statice h 51 Ethiopia, \&c.

h 1 E. Indies

h. 22 America

* The resin called gum copal, is from rhus copallinim; and the rhus coriaria was formerly much used for tanning leathet, especially in Turkey.

+ Semecarpus-see anacardium.

$¥$ Staphylea pinnata (bladder nut) is sometimes strung for beads by Roman catholics, and children will sometimes eat them, though the taste is disigreeable.

$\$$ See note in page 7 , under nectarium. 
No Genera. Growth. Species. Native of $\quad \begin{gathered}\text { No of } \\ \text { Britain, }\end{gathered}$

\section{Corols five-petuled.}

\begin{tabular}{|c|c|c|c|c|}
\hline Aldrorando & h & 1 & Italy, India & \\
\hline 9 Drosera* & h & 8 & India, Cape & Brit. \\
\hline Linum & h & 22 & Alps, Austria, Virg. & Brit. 5 \\
\hline Mahernia & & 2 & Cape & \\
\hline Sibbaldia & h & 3 & Siberia & Brit. 1 \\
\hline
\end{tabular}

\section{ORDER VI. POLYGYNIA.}

(MANY FEMALES.)

$\begin{array}{llll}293 \text { Myosurust } & \text { h } & 1 & \text { Brit. } 1 \\ \text { 294 Shefflera } & \text { h } & 1 & \end{array}$

* Sun-dew (drosera) derives its name from small drops of a liquor like dew, hanging on its fringed leaves, (which are purple) and continuing in the hottest part of the day, exposed to the sun. It is a very minute villous plant, usually growing entangled with moss on peat bogs; the leaves are curiously fringed with very numerous strong reddish hairs, terminated by small pellucid globules of viscous liquor, which occasion, by the reflection of the sun, that peculiar lustre from which its name is derived: It is in these hairs that the essential properties of the plant reside. For if a small insect should fix itself on one of the leaves, these hairs immediately begin to close one by one ; the insect being held fast by the viscous juice of the smaller hairs, till the larger hairs, together with the edges of the leaf, close in and imprison it; in which state the insect is killed, generally in less than fifteen minutes, by the operation of the acrimonious juice exuding from the ends of the hairs.

+ The number of stamens in myosurus varies greatly; it was formerly described as having five petals, but it was afterwards found they were five nectaries, and are 'צzow described as such, awled, petal-form, Sys. Veg, 14th edit. 


\title{
CLASS VI. HEXANDRIA.*-
}

\author{
(SIX STAMINA OR MAIES.) \\ Contäining five orders.
}

\section{ORDER I. MONOGYNIA.}

(ONE FEMALE.)

No Genera. Growth. Species. Native of $\quad \begin{gathered}\text { Species in } \\ \text { Britain. }\end{gathered}$

1st. Flowers calycled, + furnished with calyx and corolla.

\section{Corols one-petaled.}

$\begin{array}{llrll}1 & \text { Agapanthus } & \text { h } & 1 & \text { Cape } \\ 2 \text { Duroia } & \text { t } & 1 & \text { Surinam }\end{array}$

Corols three-petaled, or three-parted.
3 Bromelia
$\mathrm{h}$
7 W. Indies
4. Burmannia
h
5 Bursera
6 Hepetis
7 Lachenalia
$\mathrm{s}$
Ceylon
s 1
W. Indies
8 Mnasium
h
1
1
9 Tillandsia
h 1
10 Tradescantia
h 7 America
h. 8 Virginia, Malabar

* The stamina in this class being of equal length, is the distinction from the class ictradynamia, where the stamina are four long and two short.-The bulbous roots in this class, according as they smell and taste, are esculent or noxious; as daffodil, hyacinth, fritillary, \&c. having a disagreeable smell, are noxious; others are corrosive, as garlic, \&c. but by roasting or boiling they lose great part of their acrimony, and become esculent. The roots of martagon, tulip, star of Bethlehem, \&c. are esculent, having no smell.

+The caly $x$ in some genera is only a rim or border.

$\$$ Tillandsia is a parasitical plant, and grows on branches of trees, like the misleloe; the seeds are furnished with many long threads on their crowns; which as they are driven forwards by the winds, wrap round the arms of trees, and thus are held fast till they vegetate. - This is very analogous to the migration of spiders on the gossamer, who are said to attach themselves to the end of a long thread, and rise thus to the tops of trees or buildings, as the accidental breezes carry them. (Botanic Garden, part ii. p. 56.) The tillandsia lingulata is a native of Jamaica, and 


No Genera. Growth. Species. Native of $\quad \begin{gathered}\text { No of } \\ \text { Britain. }\end{gathered}$

11 Frankenia

Corals five-petaled.

\begin{tabular}{lllll}
11 Frankenia & \multicolumn{3}{c}{3} \\
& Corols six-petaled, or six-cleft. & \\
12 Berberis* & s & 4 & Crete, Siberia & Brit. 1 \\
13 Canarina & s & 1 & Canaries & \\
14 Capura & s & 1 & India \\
15 Cyrtanthus & h & 2 & Cape \\
16 Hillia & s & 1 & America \\
17 Leontice & h & 4 & Greece \\
18 Loranthus & s & 12 & China, Europe \\
19 Nandina & & 1 & Japan \\
20 Prinos & s & 2 & America \\
21 Richardia & h & 1 & Vera Crux
\end{tabular}

Corols twelve-cleft.

22 Achras

t 4 W. Indies

2d. Flowers spathed, or glumed.

23 Ehrharta h 1 Africa

Corols above, six-petaled, or six-cleft.

$\begin{array}{llrl}24 \text { Amaryllist } & \text { h } & 12 & \text { Spain, Italy, Cape } \\ 25 \text { Crinum } & \text { h } & 11 \text { Africa, America, E. Indies } \\ 26 \text { Galanthus } & \text { h } & 1 \text { Europe } & \text { Brit. t } \\ 27 \text { Hæmanthus } & \text { h } & 4 & \text { Guinea }\end{array}$

commonly grows in the fork of the greater branches of the wild cotton tree, and by the shape of its leaves catches and retains water from every shower; each leaf resembles a spout, and at its base is a reservoir containing about a pint of pure water, where it remains sheltered from the wind and the sun, often yielding refreshment to the thirsty traveller in places where water is not to be procured.

* See note to collinsonia.-Berberis vulgaris (common berbery) is said to be very hurtful to growing corn, and should not be planted near it, as at a certain period of its growth, it is apt to communicate its disease to a considerable extent. Panorama for January 1808.

+ Amaryllis disticha is used by the Hottentots to poison the points of their arrows; it is called the mad poison, from its effects. Patterson's Journey.s. 


\begin{tabular}{|c|c|c|c|c|}
\hline Genera. & Growth. & $\begin{array}{l}\text { No of } \\
\text { species }\end{array}$ & Native of & $\begin{array}{l}\text { Species in } \\
\text { Britain. }\end{array}$ \\
\hline 28 Hypoxis & $\mathrm{h}$ & 13 & Virginia, \&xc. & \\
\hline 29 Lanaria & $\mathrm{h}$ & 1 & Cape & \\
\hline 30 Leucojum & h & 3 & Germany & \\
\hline 31 Narcissus & h & 14 & Eastern & Brit. 2 \\
\hline 32 Pancratium & $\mathrm{h}$ & 9 & Ceylon, Mexico, \&c. & \\
\hline Pontederia & h & 5 & Malabar & \\
\hline \multicolumn{5}{|c|}{ Corols beneath, six-petaled. } \\
\hline 34. Allium* & $\mathrm{h}$ & 42 & Europe, Canada & Brit. $\%$ \\
\hline Aphyllanthes & h & 1 & Montpelier & \\
\hline 36 Bulbocodium & $\mathrm{h}$ & 1 & Spain & Brit. 1 \\
\hline Sowerbia & h & 1 & New Holland & \\
\hline 8 Tulbagia & $\mathrm{h}$ & 2 & Cape & \\
\hline
\end{tabular}

\section{3d. Flowers naked (without calyx.)}

39 Phormium h 3 New Zealand

Corols above, six-petaled, or six-cleft.

$\begin{array}{lccl}40 \text { Agave } & \text { h } & 4 & \text { America } \\ \text { 41 Alstroemeria } & \text { t \& h } & 5 & \text { Italy, Peru } \\ 42 \text { Gethyllis } & \text { h } & 4 & \text { Cape }\end{array}$

* The apparent and specific difference of the onion (allium cepa) from garlic, (allium sativum) is the swelling pipy stalk of the former being thicker in the middle than at either end.-Allium magicum (the magic onion) bears its bulbs on the top of the stem. See note to poligonum.

+ The flower stems in some of the species, of American aloe (agave) rise to the hight of above twenty feet: they are generally many years before they flower, but this greatly depends on the health of the plant, and heat of the climate: the flower stem rises from the centre of the radical leaves, which are closely folded over each other, and until they are fully expanded, the stem cannot advance. It continues in flower by succession, two or three months; and then the whole plant dies. See note to corypha.

The Jamaica vegetable soap is prepared from the succulent leaves of the great American aloe or coratoe (agave Americana). The cxpressed juice is reduced to a thick consistence by being exposed to the sun, or boiling; and is then made up into balls with lye ashes, to prevent it sticking to the fingers, after which it may be kept for years, and will serve for use as well as Castile soap, and hath this superior quality, of forming a lather with salt water as well as fresh: one gallon of guice will yield about one pound of soft extract. 
No of

No Genera. Growth. species. Native of

Species in Britain.

\section{Corols beneath, six-petaled, or six-cleft.}

\begin{tabular}{|c|c|c|c|c|}
\hline 43 Albuca & $\mathrm{h}$ & 5 & Cape, Abyssinia & \\
\hline 4. Aletris & h & 4 & Cape & \\
\hline 4.5 Aloe* & $\mathrm{h}$ & 12 & Africa & \\
\hline 46 Anthericum & $\mathrm{s} \& \mathrm{~h}$ & 27 & Greece, Japan, \&c. & Brit. 3 \\
\hline 47 Asparagus & $\mathrm{s} \& \mathrm{~h}$ & 13 & Cape, Asia & Brit. 1 \\
\hline 48 Asphodelus & $\mathrm{h}$ & 3 & Sicily & \\
\hline 49 Convallaria & h & 11 & Japan, \&c. & Brit. 3 \\
\hline 50 Cyanella & $\mathrm{h}$ & 3 & Cape & \\
\hline 51 Diacena & $t \& h$ & 10 & Cape, Madeira & \\
\hline 52 Erythronium & $\mathrm{h}$ & 1 & Hungary & \\
\hline 53 Fritillariat & h & 6 & Persia, Pyrenees & Brit. 1 \\
\hline 54 Gloriosaf & $\mathrm{h}$ & 2 & Malabar & \\
\hline 55 Hemerocallis & $\mathrm{h}$ & 4 & Hungary, Japan & \\
\hline 56 Hyacinthus & h & 16 & Italy, Austria, \&c. & Brit. 1 \\
\hline 57 Lindera & & 1 & Japan & \\
\hline 58 Lilium & h & 10 & Italy, America, Japan & \\
\hline 59 Massonia & $\mathrm{h}$ & 4 & Cape & \\
\hline 60 Ornithogalum & $\mathrm{h}$ & $2 Q$ & Cape, Japan, \&c. & Brit. 3 \\
\hline 61 Polianthes & $\mathrm{h}$ & 1 & India & \\
\hline 62 Pollia & & 1 & Japan & \\
\hline 63 Scilla & $\mathrm{h}$ & 12 & Italy, Japan, Peru & Brit. 2 \\
\hline 64. Tulipa & $b$ & 4 & Spain, Dantzick & \\
\hline
\end{tabular}

* The socotrine aloe (called so from the island Socotora in the E. Indies, where it is produced) is a gum resin from the aloe spicata (Sys. Veg. 14th edit.) and the hepatic or horse aloe, (which is chiefly from Barbadoes) is a coarser sort from the aloe perfoliata. Almost all the species of aloe have many varieties. The aloe of the shops is the inspissated juice of the leaves, which is said to be much used in the porter breweries.

+Fritillaria imperialis (crown imperial).-See note to bractea, page 33."

$\ddagger$ Gloriosa superba (called superb lily) is a climbing plant, (foliis cirrhiferis) and the roots whereof are poison.-Sec Asiatic Annual Register for 1805. There is only one more known species, which Linnieus calls gloriosa simplex, with pointed leaves.

$\S$ The Marquis de Gouffier mentions a curious experiment he made with the hyacinth, by placing the stem downwardis and the roots upwards in a glass, such as they are put in to blow in rooms; he found the stem would extend in the water, and the flower appear as perfect as in the air; from this experiment he supposed that the flower drew its nourishment from the interstices of the coats, and that the roots were of little use but to retain the plant in the earth. - No other bulbous plant will vegetate in the same manner. 


\begin{tabular}{|c|c|c|c|}
\hline Genera. & $\begin{array}{c}\mathbf{N}^{\circ} \text { of } \\
\text { Growth. species. }\end{array}$ & Native of & $\begin{array}{l}\text { Species in } \\
\text { Britain. }\end{array}$ \\
\hline & $\mathrm{h}$ & & \\
\hline 6 Yucc & 4 & ica & \\
\hline
\end{tabular}

4th. Flowers incomplete.

67 Acorus
68 Calamus
69 Juncus
70 Orontium
71 Peplis
h 1 Holland
h 1 India
h 22 Europe
h 2 Virgrinia, Japan
h 2 Jamaica

Brit. 1

Brit. 15

Brit. 1

\section{ORDER II. DIGYNIA.}

\section{(TWO FEMALES.)}

72 Atraphaxis
73 Falkia
74 Gahnia
75 Nectris
76 Oryza

$\begin{array}{lll}\text { s } & 2 & \text { Cape } \\ \text { h } & 1 & \text { Cape } \\ \text { h } & 1 & \\ \text { h } & 1 & \\ \text { h } & 1 & \text { E. and W. Indies }\end{array}$

\section{ORDER III. TRIGYNIA.}

(THREE FEMALES.)

\section{1st. Flowers beneath.}

$\begin{array}{llll}77 \text { Colchicum* } & \text { h } & 3 \text { Spain } \\ 78 \text { Helonias } & \text { h } & 2 & \text { Pensilvania } \\ 79 \text { Madeola } & \text { h } & 2 \text { Africa, Virginia }\end{array}$

Brit. 1

* The hermodactyls of the shops, is supposed to be the root of a species of colchicum, called colchicum variegatum. The colchicum autumnale (common meadow saffron, called so from its similarity to the autumnal crocus, which produces the saffron) is impregnated when it flowers in autumn, which matter of impregnation descending down the tube of the pistillum to the germen within the bulb, is there maturated during winter; the plant then shoots up again in spring to disperse the seeds, with only leaves and a fruit-stalk with a capsule of three lobes, containing the seed, so that this plant produces its purple flowers in autumn, and its leaves and fruit in the spring following. The bulbs of this plant are poisonous, but are given with caution in some pestilential and putrid cases; and also in a dropsy, in the form of an oxynel, with honey and vinegar. (N. B. This plant hath many varieties). See its effects in an inveterate dropsy, in the Universal Museum for June, 1766. 


No Genera. Growth $\begin{aligned} & \text { No of } \\ & \text { species. Native of }\end{aligned} \quad \begin{gathered}\text { Species in } \\ \text { Britain. }\end{gathered}$

80 Melanthium h 8 Cape, America, Siberia

81 Rumex s \& h 31 Egypt, Alps, \&c. Brit. 11

82 Scheuchzeria h 1 Helvetia

83 Triglochin h 3 Europe

84 Trillium

85 Wurmbea

h' 3 Canada

Brit. 2

1 Cape

2d. Flowers above.

86 Flagellaria . s ' 1 Java.

\section{ORDER IV. TETRAGYNIA.}

(FOUR FEMALES.)

87. Petiveria

a 2 W. Indies

ORDER V. POLYGYNIA.

(MANY FEMALES.)

88 Alisma

h 8 Europe

Brit. 3 


\section{CLASS VII. HEPTANDRIA.}

(SEVEN STAMINA OR MALES.)

Containing four orders.

\section{ORDER I. MONOGYNIA.}

(ONE FEMALE.)

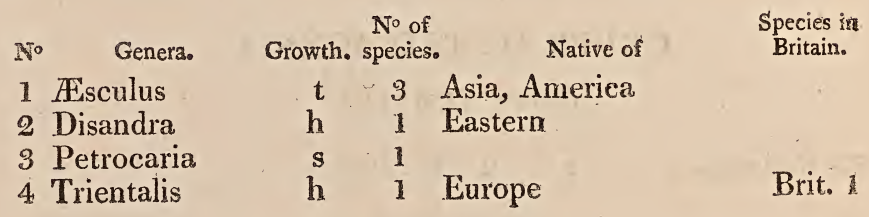

ORDER II. DIGYNIA.

(TWO FEMALES.)

L Limeum h 2 Africa

ORDER III. TETRAGYNIA.

(FOUR FEMALES.)

6 Aponogeton $*$ h 2 E. Indies

7 Saururus h 1 Virginia

\section{ORDER IV. HEPTAGYNIA.}

(SEVEN FEMALES.)

8 Septas h 1 Cape

* The stamens in aponogeton are uncertain as to number, being from 6 to $i \mathcal{F}_{6}$ 


\section{CLASS VIII. OCTANDRIA.}

(EIGHT STAMINA OR MALES.)

Containing four orders.

\section{ORDER I. MONOGYNIA. \\ (ONE FEMALE.)}

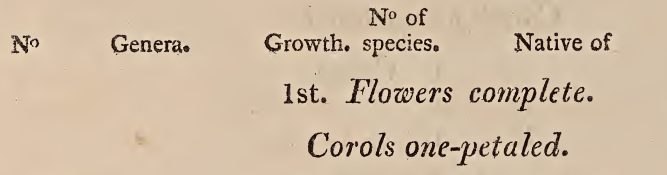

1 Erica

2 Michauxia

3 Vaccinium

s \& h 74 Many places

Brit. 4 h 1

$\mathrm{s} \quad 15$ Europe

Species in

Britain.

Corols four-petaled.

4. Allophyllus

5 Amyris*

6 Anticorus

7 Combretum

8 Elaphrium

9 Epilobium

10 Gaura

11 Grislea

12 Guarea

13 Hedwigia

14. Jambolifera

15 Lawsonia†

$\begin{array}{lll}\text { s } & 1 & \text { Ceylon } \\ \text { s } & 9 & \text { Carolina } \\ \text { s } & 1 & \text { Arabia } \\ \text { s } & 2 & \text { America } \\ \text { h } & 1 & \\ \text { h } & 7 & \text { Alps } \\ \text { h } & 1 & \text { Virginia } \\ \text { s } & 1 & \text { America } \\ \text { s } & 1 & \text { Brasils } \\ \text { s } & 1 & \\ \text { s } & 1 & \text { India } \\ \text { s } & 3 & \text { Egypt, India }\end{array}$

Brit. 7

* Amyris opolalsamum is a native of Arabia, (of the same genus with the talm of Gilead) the juice, when first extracted from the tree, is white, it then becomes green, and afterwards gold colour, which tarnishes as it grows old. It is often mixed with the turpentine of cyprus, but the cheat may be discovered by pouring it into a basin of water; when pure, it turns yellow, dissolves, and unites with the water, afterwards it disengages itself, and rises to the surface as white as milk; but if adulterated, it falls to the bottom, to which it adheres without changing colour.

+ Lawsonia inermis, called in Egypt henna or alhenna, a shrub like privet, with the juice of which they stain the nails of their hands and feet of a bright yellow colour. 
No Genera. Growth. species. Native of $\begin{gathered}\text { No of } \\ \text { Species in } \\ \text { Britain. }\end{gathered}$

16 Melicocca

17 Melicope

18 Menecylon

19 Enothera

20 Ophira

21 Osbeckia

22 Rhexia

23 Ximenia

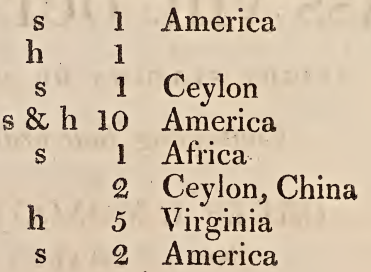

Corols five-petaled.

$\begin{array}{lllll}\text { 24 Bæckea } & \text { s } & 1 & \text { China } \\ \text { 25 Ephielis } & \text { h } & 1 & \\ 26 \text { Hypelate } & \text { h } & 1 & \\ \text { 27 Trigonis } & & 1 & \\ \text { 28 Tropæolum } & \text { h } & 4 & \text { Peru }\end{array}$

Corols eight petals, or eight-cleft.

29 Chlora

30 Fuchsia*

31 Mimusops h 4 Italy

$\mathrm{s} \& \mathrm{~h} \quad 3$ America

s 2 India

Brit. 1

2d. Flowers incomplete.

Calyx four or five leaves, or four ar five cleft.

32 Athenæa, cal.6 parts h 1

33 Cedrota, cal. 1 leaf 1

34. Daphne

s. 17 Alps, India

Brit. 2

35 Dirca, no calyx t 1 Virginia

36 Dodonæa

37 Gnidia

s 2 India

38 Lachnæa

39 Passerina

40 Skinnera

41 Stellera

42 Valentinia

s 11 Africa

s 2 Ethiopia

s \& h 13 Cape

h 1

h 2 Germany

h 1

* Both in the Gen. Plan. and in the Sys. Veg. fuchsia is described as having no calyx; but Mr. Aiton, in Hortus Kewensis, describes the fuchsia coccinea as having calyx 1-phyllus, coloratus, corollifer, maximus; petala 4, parva; bacca infera, A-locularis, polysperma. 


\section{ORDER II. DIGYNIA.}

(TWO FEMALES.)

$\mathrm{N}^{\circ}$, of

No Genera.

Growth. species.

Native of

Species in

Corols four-petaled.

43 Codia

44. Galenia, cor. none

45 Moehringia

46 Schmiedelia

47 Weinmannia
1 Mountains

2 Africa

h 1 Alps

s 1 E. Indies

s 4. Jamaica

ORDER III. TRIGYNIA.

(THREE FEMALES.)

Corols four-petaled.

48 Cardiospermum

49 Paullinia

50 Ponæa

51 Sapindus

52 Coccoloba

53 Polygonum* $\begin{array}{lrl}\mathrm{s} & 2 & \text { America } \\ \mathrm{s} & 15 & \mathrm{E} . \& \mathrm{~W} \text {. Indies }\end{array}$

h 1

t 4 E. \& W. Indies

Corots none.

Britain.

\section{t 7 Barbadoes}

s \& h 31 America, E. Indies Brit. 10

\section{ORDER IV. TETRAGYNIA.}

\section{(FUUR FEMALES.)}

Corols four-petaled.

$\begin{array}{llll}\text { 54 Adoxa, } 4 \text { or } 5 \text { cleft } & \text { h } & \text { 1 Dantzick } & \text { Brit. 1 } \\ 55 \text { Elatine } & \text { h } & \text { 2 France } & \text { Brit. 1 } \\ 56 \text { Haloragis } & \text { h } & \text { 1 New Caledonia } & \\ 57 \text { Paris } & \text { h } & \text { 1 Dantzick } & \text { Brit. 1 }\end{array}$

* The root of polygonum listorta (bistort) is one of the strongest vegetable bitters. (See tormentilla). The stamens are uncertain as to number. The polygonum viviparum (viviparous bistort) receives its name from its producing (after impregnation) a living offspring of buds instead of seed, which, when ripe, fall to the ground and grow.-The same occurs in the allium magrcum (the magic onion) and other bulbiferous plants; only, the one bears luds, and the other bults. 


\section{CLASS IX. ENNEANDRIA.}

(NINE STAMINA OR MALES.)

Containing three orders.

\section{ORDER I. MONOGYNIA.}

(ONE FEMALE.)

No Genera.
1 Anacardium*
2 Cassyta
3 Laurust
4 Tinus

No of

Growth, species. Native of

Species in

Britain.

$\begin{array}{rrl}\text { t } & 1 & \text { E. \& } W . \text { Indies } \\ \mathbf{h} & 2 & \text { India } \\ \text { s } & 16 & \text { India, Persia } \\ \text { s } & 1 & \text { W. Indies }\end{array}$

ORDER II. TRIGYNIA.

(THREE FEMALES.)

5 Rheum h 7 China, Asia

ORDER III. HEXAGYNIA.

(SIX FEMALES.)

6 Butomus h 1 Europe Brit. 1

* The milky juice of the true anacardium occidentale (Cashew nut) will stain linen of a deep black, which cannot be washed out; and Mr. Miller says, the inspissated juice of the tree is the best sort of lack, which is used for staining of black in China and Japan.-The semecarpus anacardium is used for the same purpose.

t The true cinnamon is the bark of the laurus cinnamomum; and the base cinnamon, which is often sold for the true, is the bark of the laurus cassia. - The commercial drug, camphor, is obtained from another species of laurus, called laurus camphora; but camphor may be also obtained, in small quantities, from the roots of zedoary, thyme, rosemary, sage, anemony, \&c. by distillation. Thyme and peppermint, slowly dried, afford much camphor. (Gregory's Economy of Nature, v. iii. p. 52). Laurus lenzoin from Sumatra, is said to be the true benzoin of the shops.-Phil. Soci. at Haarlem.-See terminalia benzoin. The stamens in laurus vary as to number. Laurus nolilis is the laurel of the antients, the berries of which are an article of commerce, and are esteemed carminative, \&c. 


\title{
CLASS X. DECANDRIA.
}

(TEN STAMINA OR MALES.)

\author{
Containing five orders.
}

\section{ORDER I. MONOGYNIA.}

(ONE FEMALE.)

No Genera. Growth. $\begin{gathered}N^{\circ} \text { of } \\ \text { species. Native of }\end{gathered}$

\section{1st. Flowers many-petaled, irregular.}

$\begin{array}{ll}1 & \text { Anagyris } \\ 2 & \text { Bauhinia } \\ 3 & \text { Cæsalpinia } \\ 4 & \text { Cassia } \\ 5 & \text { Cercis* } \\ 6 & \text { Dictamnus }\end{array}$

$\begin{array}{crl}\text { s } & 1 & \text { Italy } \\ \text { s } & 8 & \text { E. \& W. Indies } \\ \text { t } & 3 & \text { E. \& W. Indies } \\ \text { s \& h } & 38 & \text { E. \& W. Indies } \\ \text { s } & 2 & \text { Italy, Canada } \\ \text { h } & 2 & \text { Cape, Germany }\end{array}$

* Cercis siliquastrum (Judas tree) is supposed to be the tree on which Judas hanged himself, from whence the name.

+ If a candle is applied to the stalks of the fraxinella (dictamnus albus) which are covered with a kind of resinous matter, it will burn like spirits of wire, until all the essential oil is consumed, without burning the stalks; and it is said, the atmosphere which floats around the fraxinella is inflammable, supposed to arise from an exhalation of its essential oil. (See preface). For all essential olls are inflammable, and pethaps may be only different modifications of that universal inflammable oil called petroleum (oil of petre, or rock oil) which is extremely subtle and volatile, and as it is plentifully diffused in the atmosphere, and found more or less in many different bodies, is supposed to invade and be a constituent part in almost all bodies, in some form or other. (See William's Natural History of the Mineral Kingdom, v. i. printed in 1789 ). Petroleum is perhaps a principal ingredient in all bituminous matter, as coal, amber, \&c. ; and being brought down from the rocks and mountains in Persia, Tartary, \&c. is found floating on the surface of certain springs and lakes under the name of naphtha, which is so very inflammable, that if a lighted. candle be held near to the surface of the water, it immediately takes fire to a considerable extent. There is also a well at Ancliff near Wigan, in Lancashire, called. the bitrning well, the surface of which will flame on application of a candle (though the water is very cold) which is said to be petroleum issuing from the neighbouring coal mines. - There is also a similar phænomenon in the western parts of Virginia, called the burning spring. This oil is also found in several other parts of America, either floating on water, or issuing out of the ground, particularly in Barbadoes, where it is called Burladoes tar. 


\begin{tabular}{|c|c|c|c|c|}
\hline Gencra. & Growth. & $\begin{array}{l}\text { No of } \\
\text { species. }\end{array}$ & Native of & $\begin{array}{l}\text { Species ist } \\
\text { Britafn. }\end{array}$ \\
\hline 7 Guilandina* & & 5 & E. \& IV. Indies & \\
\hline 8 Hymienaat & $\mathrm{t}$ & 1 & W. Indies & \\
\hline 9 Myroxylont & & 1 & Peru & \\
\hline 10 Parkinsonia & $\mathrm{t}$ & 1 & W. Indies & \\
\hline 11 Poincianaø & s & 3 & E. \&. W. Indies & \\
\hline 12 Rhodora & $\mathrm{h}$ & 1 & & \\
\hline 13 Sophora & s \& $\mathrm{h}$ & 13 & Levant, Cape, \&c. & \\
\hline 14. Toluifera & $\mathbf{t}$ & 1 & S. America & \\
\hline
\end{tabular}

\section{2d. Flowers many-petaled, equal.}

\begin{tabular}{|c|c|c|c|}
\hline 15 Adenanthera & $\mathrm{t}$ & 2 & India \\
\hline 16 Bergera & $\mathbf{s}$ & 1 & Africa \\
\hline 17 Chalcas & $\dot{s}$ & 1 & India \\
\hline 18 Clethra & $\mathrm{s}$ & I & Carolina \\
\hline 19 Cynometra & $\mathrm{s}$ & 2 & India \\
\hline 20 Dionæaฮा & $\mathrm{s}$ & 1 & Carolina \\
\hline 21 Ekebergia & & 1 & Cape \\
\hline 22 Fagonia & h & 3 & Crete, Spain, Arabia \\
\hline 23 Guajacum \|\| & $t$ & 3 & W. Indies, Africa \\
\hline 24. Hæmatoxylon & $\mathrm{t}$ & 1 & Campechy \\
\hline 25 Heisteria & $\mathrm{s}$ & 1 & Martinico \\
\hline 26 Jussieua & $\mathrm{s}$ & 6 & Lima, India \\
\hline 27 Ledum & $s$ & 1 & Europe \\
\hline 28 Limonia & $\mathrm{s}$ & 3 & India \\
\hline
\end{tabular}

* On the Malabar coast, the roots of guildindina moringa are scraped and used as horse-radish, and have much the same taste. Though this tree is considered as a species of the genus guilandina, it seems to be erroneous, as there are nine stamina, five of which are fertile, and four barren.

+ The resin called gum anime is from hymenca courbaril.

¥ The balsam of Peru is from myroxylon peruiferum.

Flower fence, (poinciana) is so called, because they make fences with it in Barbadoes to divide land: it hath a beautiful flower, and is armed with spines.

II The lalsam of tolu is from toluifera lalsamum.

If Dionaca muscipula is a very remarkable sensitive plant, having succulent leaves, which spread upon the ground, and at the end of each leaf are two lobes, or lips, an inch broad, fringed on the margin with a row of stiff hairs; and on a fly or any thing being introduced between them, they immediately close; hence the specific name muscipula (fly-trap) nor do they open again while the dead animal continues there, whenre it is supposed to contribute to the nutriment of the plant.

Hlil Gum guajacum is from guajacum officinale.-See buxus. 


\begin{tabular}{|c|c|c|c|c|}
\hline Genera. & Growth. & $\begin{array}{l}\text { No of } \\
\text { Species }\end{array}$ & Native of & $\begin{array}{l}\text { Species in } \\
\text { Britain. }\end{array}$ \\
\hline 29 Melastoma & $\mathbf{s}$ & 15 & America, Malabar & \\
\hline 30 Melia** & $\mathrm{t}$ & $\mathscr{2}$ & Syria, Spain, Ceylon & \\
\hline 1 Monotropa & h & 2 & Canada & Brit. 1 \\
\hline 2 Murraya & s & 1 & E. Indies & \\
\hline Myrospermur & h & 1 & & 1 \\
\hline 4. Petaloma & & 1 & & \\
\hline 5 Prosopis & $\mathrm{t}$ & 1 & India & \\
\hline 36 Pyrola & h & 6 & Europe & Brit. 3 \\
\hline 37 Quassiat & s & 2 & Surinam & \\
\hline 38 Quisqualis & $\mathrm{s}$ & 1 & India & \\
\hline 39 Ruta & s & 5 & Batavia, Europe & il \\
\hline Swietenia & $\mathrm{t}$ & 1 & America & 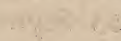 \\
\hline Thryallis & $\dot{s}$ & ] & Brasil & \\
\hline Tribulus & h & 4 & Jamaica, France & \\
\hline Trichilia & $\mathrm{s}$ & 3 & Jamaica & \\
\hline Turræa & s & 1 & E. Indies & \\
\hline Zigophillu & s \& & 11 & Syria, \&c. & \\
\hline
\end{tabular}

* The melita azedarach is greatly esteemed in Ceylon: it is an admirable succedanium for the cinchona officinalis, and its leaves are very obnoxious to moths and other insects.

+ Quassia is said properly to belong to dioecia decandria; especially as to some of the species, as the quassia simarouba is of two houses. It is said that the root of quassia is more certain than the bark in the cure of intermittents, as it will stop vomitting, and stay on the stomach when the bark will not; the dose is a dram, either with or without Virginia snake root. Quassia polygama is mentioned as a species to quassia in the "Transactions of the Royal Society of Edinburgh," vol. 3, though it is not in the Sys. Veg. and is also of two houses. It is a native of Jamaica and other western islands, and grows to a very large tree, above 100 feet in hight, and 10 or more feet in circumference. It is called batter urood, or bitter ash, as both bark and wood are intensely bitter, but especially the wood. It is also given in fevers and agues, either alone or with the batk; the dose is from 15 grains to a dram. The bark of this tree hath for some time been exported to England in considerable quantities for the purposes of the brewers of ale and porter; and is said to be sold in London for the quassia amara, and answers all the same purposes: but the stem of the quassia amara never exceeds two inches in diameter, and is very scarce and dear. Linnæus says it received its name from a slave called Quassi, who first discovered its virtues.

¥ The genus swietenia is very similar to cedrela.

$\S$ This seems to be the same plant mentioned by Virgil, under the name of iribulus. It is called in English caltrops, from the form of the fruit resembling those instruments of war, strewed in the enemies' way to annoy their horses. It is a troublesome weed amongst the corn in some parts of France and Spain, annoying: the feet of the cattle with its strong prickles. The species is tribulus terrestris. 
X7o Genera. Growth. species. Native of $\begin{gathered}\text { No of } \\ \text { Britain. }\end{gathered}$

3d. Flowers one-petialed, equal.

$\begin{array}{lrrll}46 \text { Andromeda } & \text { s } & 16 & \text { Alps, Lapland } & \text { Brit. 2 } \\ 47 \text { Arbutus* } & \text { s } & 9 & \text { Acadia, Spain } & \text { Brit. } 3 \\ 48 \text { Codon } & \text { h } & 1 & \text { Royen } & \\ 49 \text { Epigae } & \text { s } & 1 & \text { Virginia } & \\ 50 \text { Gaultheria } & \text { s } & 2 & \text { Canada } & \\ \text { 51 Inocarpus } & \text { s } & 1 & \text { Taheite } & \\ \text { 52 Kalmiat } & \text { s } & 2 & \text { Virginia } & \\ \text { 53 Nicandra } & & 1 & & \\ \text { 54 Rhododendror } & \text { s } & 7 & \text { Alps, America } \\ \text { 55 Styrax } & \text { t } & 1 & \text { Italy } & \end{array}$

4th. Flowers without petals, or incomplete.

36 Bucids

57. Casearea

58 Copaifera

59 Crudia

60 Cyclas

61 Dais

62 Samyda s. 1 Jamaica

I.

1 Brasil, Antillas

l

I

s 2 Cape

$\mathrm{s} 5 \mathrm{~W}$. Indies

\section{ORDER II. BIGYNIA. \\ (TWO FEMAEES.)}

Corols none.

63 Chrysosplenium h 64. Scleranthus $\oint$ h

2 Germany

65 Trianthema
Corols one-petaled.

3 Germany

Brit. 2 Brit. O

66 Royena $\quad 5$ Cape

* The arbuius uva ursi (bear-berries) is an evergreen, and very common in Spain. but is called by different names in different districts, the most common name is gayubal; it is in high fame in calculous and scorbutic cases. Dillon's Travels through Spain, printed $\mathbf{1 7 8 2}$.

$\uparrow$ Kálmia-see note to collinsonia.

¿ Balsam cospaiti is from copaifera officinalis.

$\$$ The Scleranthus perennis is the plant on which the coccus polonicus (Germar: cochineal) is found. $\rightarrow$ See coctus and quercus. 


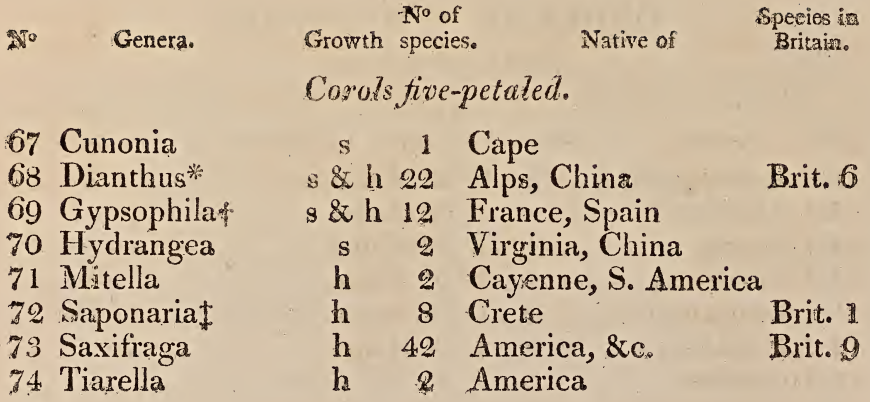

\section{ORDER III. TRIGYNIA.}

\section{(THREE FEMALES.)}

\begin{tabular}{|c|c|c|c|}
\hline 75 Banisteria & $\mathrm{s}$ & 7 & W. Indies, Bengat \\
\hline 76 Erythroxylon, dru. & $\mathbf{s}$ & 2 & Jamaica \\
\hline 77 Garidella & $\mathrm{h}$ & 1 & Italy \\
\hline 78 Malpighia, berry & $t$ & 9 & W.Indies \\
\hline 79 Triopteris & \& & 1 & Jamaica \\
\hline
\end{tabular}

Capsules one-celled.

80 Arenaria

81 Stellaria h 26 Bavaria, Austria

h 9 Europe
Brit. 8

Brit. 3

Capsules three-celled.

82 Cherleri
83 Cucubalus
84. Deutzia
85 Hiræa
86 Silene

h 1 Alps,

h 1.5 Siberia, Italy

Brit. 1

82 Cherleri

84. Deutzia

85 Hiræa

1 Japan

s 1 Carthagena

h 37 Crete, Egypt

Brit. 4

Brit. \&

* Formerly only those plants with broader-leaves were called sweet William, funder dianthus barbatus); and those with narrower leaves were called sweet Jolin.

+ Gypsophila struthium is the plant or shrub, Linnæus tells, was used by the antients instead of soap, and that it is now used in Spain for the same purpose.

$¥$ Saponaria officinalis (common soap-wort) so called as being used in a decoction to scour and cleanse woollen cloths; and poor people in some places use it to wash with instead of soap.

$\S$ Silene muscipula, silene armeria, and lychnis viscária, are called catchfies, from a viscous matter surrounding the stalk for about an inch in length below the Hower, which will detain small flies and insectṣ. 


\section{ORDER IV. PENTAGYNIA.}

(FIVE FEMALES.)

\begin{tabular}{|c|c|c|c|c|c|}
\hline No & Genera. & Growth. & $\begin{array}{l}\text { No of } \\
\text { species. }\end{array}$ & Native of & $\begin{array}{c}\text { Species in } \\
\text { Britain. }\end{array}$ \\
\hline $8 \%$ & Agrostemma & h & 47 & Europe & Brit. I \\
\hline 88 & Averrhoa* & $\mathrm{s}$ & 21 & India & \\
\hline 89 & Bergia & h & 23 & Cape & \\
\hline 90 & Cerastium & h & 16 & Alps & Brit. 8 \\
\hline 91 & Cotyledon & $h^{\prime}$ & 15 & Cape, Siberia & Brit. 2 \\
\hline 92 & Forskohlea & h & 3 & Cape & \\
\hline 93 & Grielum & s & 1 & Athiopia & \\
\hline 94 & Joncoquetia & h & 1 & & \\
\hline 95 & Lychnist & $\mathrm{h}$ & 10 & Siberia & Brit. 3 \\
\hline 96 & Oxalis & h & 26 & Africa, America & Brit. 1 \\
\hline 97 & Penthorum & h & 1 & Virginia & \\
\hline 98 & Sedum & $\mathrm{h}$ & 20 & Europe, \&c. & Brit. 8 \\
\hline 99 & Spergula & h & 5 & Europe & Brit. 4 \\
\hline 100 & Spondias $\ddagger$ & $t$ & 2 & W. Indies & \\
\hline 101 & Suriana & s & 1 & W. Indies & \\
\hline
\end{tabular}

ORDER V. DECAGYNIA.

(TEN FEMALES.)

\begin{tabular}{|c|c|}
\hline & \\
\hline 03 Phytolacca & $\mathrm{s} \& \mathrm{~h}$ \\
\hline
\end{tabular}

* Averrhoa carambola is a remarkable sensitive tree, similar to some species of mimosa; it grows in Bengal, and is there called camruc or camrunga. The stamina are ten, yet only the five longer have antheræ; the leaves are alternately pinnated, with an odd one; the moving quality is only in the leaves (not the petiole) which will bend down from the petiole so as to touch one another with their under sides, yet the petiole is the sensitive part which must receive the touch, or be some way injured by it, to affect the leaves; the touch must be by striking the part with the nail or any hard body, for if the branch is moved gently by the hand or wind, no motion takes place: after sun-set the leaves go to sleep, by bending down from the petiole, so as to touch by their under sides: the other species of this genus have no sensitive power. Philo. Trans. vol. 75.

In the 8th edit. of Gen. Plant. averrhoa is placed in monadelphia decandria.

+ In bachelor's button (lychnis dioica) the male and female flowers grow on different plants.

+ The wood of the spondias momin is so soft and spongeous, that it is used to stop bottles instead of cork; and is said to be brought to England for that purpose. 


\section{CLASS XI. DODECANDRIA.}

(TWELVE STAMINA OR MALES.)

This class, although its title is expressive of twelve stamina only, consists of such plants as are furnished with any number of stamina from eleven to mineteen inclusive. And it is also to be observed, that in this class the stamina are fixed to the receptacle, but in the next class they are fixed to the calyx or corolla.

OBs. The reason of the chasm in the classes from ten to twelve stamina, is, that no flowers have yet been found with only eleven, so constant as to form a class. Reseda hath sometimes only eleven, but ofter more, yet never exceeding fifteen.

This class contains five orders.

\section{ORDER I. MONOGYNIA.}

(ONE FEMALE.)

No Genera. Growth. species. Native of $\quad \begin{gathered}\text { Species in } \\ \text { Britain. }\end{gathered}$

Corols none.

$\begin{array}{llrll}1 \text { Asarum } & \text { h } & 3 \text { Canada, Europe } & \text { Brit. } 1 \\ 2 \text { Bocconia } & \text { s } & 1 \text { Jamaica } & \\ 3 \text { Hudsonia } & \text { s } & 1 \text { Virginia } & \\ \text { 4. Tomex } & & 1 \text { Japan }\end{array}$

Corols four-petaled, or four-cleft.

5 Apactis

6 Cratæva

7 Garcinia*

$\begin{array}{lll} & 1 & \text { Japan } \\ \mathrm{t} & 3 & \text { Indies } \\ \mathrm{t} & 3 & \text { E. Indies }\end{array}$

* Garcinia mangostana (mangostan or mangosteen) is about the size of ar. orange, the inside is divided like the orange, by several thin partitions, in which the seeds are lodged; surrounded by a pulp of most delicious flavour; and is esteemed one of the richest fruits in the world. - See the note to annona. 


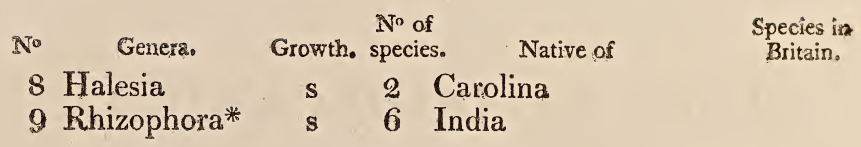

\section{Corols five-petaled.}

10 Camellat

11 Dodecas

12 Eurya

13 Nitraria

14. Peganum

15 Portulaca

16 Triumfetta

17 Vatica

18 Banara

19 Blakea

20 Ginora

21 Gethyllis

22 Lythrum

23 Befaria

94. Bassia t 1 America

s 1 Surinam

1 Japan

s 1 Volga

h 2 Assyria

h 10 Europe, America

$\mathrm{s} 4$ Indies

s 1 China

Corols six-petaled.

h 1

s 2 Jamaica

s 1 America

h 1, Africa

s \& h 15 America, \&c.

Brit. 2

Corols seven-petaled.

h 2 New Granada

Corols eight-cleft.

h 2 Malabar

Corols ten-petaled.
25 Decumaria
s 1 Barbary

* Rhizophora candel is called the kandel or candle of the Indians, because the wood, which is very solid and heavy, makes the clearest, most ardent, and durable fire, of any other materials.

The bark called canella alba, is from canella alba. 


\section{ORDER H. DIGYNIA.}

(TWO FEMALES。)

\begin{tabular}{|c|c|c|c|c|}
\hline Genera. & Growth. & $\begin{array}{l}\text { No of } \\
\text { species. }\end{array}$ & Native of & $\begin{array}{c}\text { Species irz } \\
\text { Britain. }\end{array}$ \\
\hline 26 Agrimonia* & h & & Europe & Brit. 1 \\
\hline 27 Heliocarpust & $\mathbf{t}$ & 1 & America & \\
\hline
\end{tabular}

\section{ORDER III. TRIGYNIA.}

(THREE FEMALES)

\begin{tabular}{|c|c|c|c|}
\hline 28 Euphorbia & $\mathrm{s} \& \mathrm{~h}$ & & Canaries, \&c. \\
\hline 29 Pallasiat & $\mathrm{s}$ & 1 & Caspian Sea \\
\hline 30 Resedaई & h & 12 & France \\
\hline 31 Tacca & h & 1 & E. Indies, Taheite \\
\hline 32. Visnea & $\mathrm{s}$ & $i$ & Canaries \\
\hline
\end{tabular}

\section{ORDER IV. PENTAGYNIA.}

(FIVE FEMALES.)

33 Glinus
h 2 Spain

ORDER V. DODECAGYNIA.

(TWELVE FEMALES.)

34. Sempervivum s \& h 8 Canaries Brit. I

* In Agrimonia the stamens are very uncertain in number, are often under 12.

+ Heliocarpus, (sun-fruit) called so from the capsule being surrounded with threads representing rays,

¥ Pallasia-see note to calligonum.

\$ Searce any genus in which the character is more difficult to determine than in reseda, for it varies both in number and figure in different species. The essential character consists in the petals being three-cleft, one at the base being melliferous, and a capsule not closed, but always gaping. 


\title{
CLASS XII. ICOSANDRIA.
}

\author{
(TWENTY STAMINA. OR MALES.)
}

The plants of this class furnish most of the eatable fruits in esteem; none are noxious except the cherry-laurel. The flowers bear the following character:

1st. A calyx of one leaf, and concave.

2d. The corolla fastened by its claws into the inner side of the calyx.**

3d. The stamina, twenty or more, inserted also into the inner side of the calyx or corolla.

OBS. As the number of stamina in this class is not limitted, great attention must be had to the above character, to distinguish it from the next class (potyandrio) where the stamina are inserted into the receptacle.

This class contains five orders.

\section{ORDEP I. MONOGYNIA.}

(ONE FENALE.)

No Genera. Growth. Species. Native of $\quad \begin{gathered}\text { No of } \\ \text { Britain. }\end{gathered}$

Calyx above.

$\begin{array}{llrr}1 \text { Cactust } & \mathrm{s} & 24 & \mathrm{~W} \text {. Indies, Mexico } \\ 2 \text { Calyptranthes } & \mathrm{s} & 1\end{array}$

* When the corolla is inserted into the calyx, it always consists of many petals ; and the calyx of one leaf.

+ The cactus pitajaya (one of the erect cereises in California) grows with a triangular stem, but the brariches are said to be fluted, and it bears a most delicious fruit. - The cochineal animals (coccus infectorius) are supported on a species of the cactus, called cacius cochenillifer; and from cochineal the best carmine is extracted. (See celeranthus and quercus). The flower of the cactus grandiflorus (one. of the creeping cereuses) is said to be as grand and beautiful as any in the vegetable system : It begins to open in the evening about seven o'clock, is in perfection about eleven, and fades about four in the morning, so that the same flower only continues in perfection about six hours. The calyx, when expanded, is about a foot in diameter, of a splendid yellow within, and a dark brown without; the petals are many, and of a pure white; and the great number of recurved stamina surrounding the style in the centre of the flower, make a grand appearance, to which may be added the fine scent, which perfumes the air to a considerable distance. It flowers in July. 
No of

No Genera. Growth. Species.

Species in

3 Eugenia

4 Fabricia

s 7 Malacca, India

5 Leptospermum * $\mathrm{s}$

s 1 New Holland

6 Metrosideros

11 New Holland

7 Myrtust .

5 New Holland

8 Philadelphus

14 Europe, Asia

9 Psidium

10 Punicaf

$\begin{array}{lll}\mathrm{s} & 4 & \text { Verona, Carolina } \\ \mathrm{t} & 3 & \text { E. } \& \text { W. Indies }\end{array}$

t 2 Spain, \&c.

Calyx beneath.

\begin{tabular}{|c|c|c|c|}
\hline 11 Amygdalus & $\mathrm{t}$ & 4 & Persia, Jordan \\
\hline $\mathcal{L}$ Chrysobalanus & $\mathrm{t}$ & 1 & America \\
\hline Plinia & $\mathrm{t}$ & 2 & Surinam \\
\hline Prunus & $\mathrm{t}$ & 22 & Amer.Siberia,Armeniaca Brit.6 \\
\hline 5 Sonneratia & $\mathrm{t}$ & 1. & New Guinea \\
\hline
\end{tabular}

ORDER II. DIGYNIA.

(TWO FEMALES.)

16 Cratægus\| $\quad$ s 15 India Brit. 3

* Leptospermum scoparium (New Zealand tea) of great use in the voyages of Captain Cook.

† The common myrtle (myrtus communis) hath many varieties.

$\$$ The balaustines of the shops are the calyx and corolla of the double flowering pomegranates (punica granatum).

§ Prunus, by the laws of botany, is a genus, which contains as its relative species, the plum, cherry, apricot, and laurel, with their several varieties; but Mr. Miller thinks that the plum and cherry ought to have had a separate genus, as they will not grow upon each other, either by budding or grafting; though it is said by some, that a cherry will grow on a plum-stock, but not a plum on a cherry-stock. Prumus Cerasus, (the cherry); Linnæus retains the Latin name Cerasus, as being supposed the native place; the town is situated in Natolia, on the banks of the Euxine or Black Sea, famous for cherrics, and from whence Lucullus first brought them into Italy.

II The cratrogus, sorlus, and mespilus, are very near allied, the females in each vary as to number: The leaves of cratogus are angled, of sorbus are feathered, of mespilus commonly entire. 


\title{
ORDER III. TRIGYNIA.
}

\author{
(THREE FEMALES.)
}

No Genera.
17 Sesuvium
18 Sorbus*

No of

Growth. species. Native of

Species in Britain.

$\begin{array}{lll}\mathrm{s} & 1 & \text { India } \\ \mathrm{t} & 3 & \text { Europe }\end{array}$

Brit. 3

\section{ORDER IV. PENTAGYNIA.}

\author{
(FIVE FEMALES.)
}

\section{Calyx above.}

19 Mesembryanthemum $\uparrow$ s\&h 50 Africa, \&c.

\begin{tabular}{|c|c|c|c|}
\hline 20 Mespilus & $\mathrm{s}$ & 8 & Canada \\
\hline 21 Pyrus & $\mathrm{t}$ & 9 & Cydonia \\
\hline \& Tetragonia & $s \& h$ & 7 & ÆEthiopia \\
\hline
\end{tabular}

\section{Calyx beneath.}

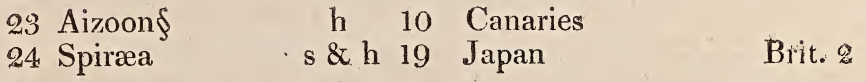

* The berries of the sorbus aucuparia (mountain ash) have been considered as useless, if not pernicious; but in Merionethshire in Wales, thev are not only considered as a pleasant viand, but are manufactured also into an intoxicating liquor, called by the Welsh diod-griafol. Warner's second Walk through W'Wles, 1799.

+ In the year 1794 a whole volume was published on the genus mesembryanthemum, describing upwards of 136 species (though Linnæus only enumerates 50) by Adrian Hardy Haworth, ...... 8vo. 480 p.p. 6 s. Linnæus bath divided the species into such as have white corols, red corols, and yellow corols; and Mr. Aiton hath met with one that hath green corols.

$\ddagger$ Pyrus is the generic name for apple, pear, and quince; as having (according to Linnæus) the same generic character; but as the apple will not grow grafted on the pear or quince, nor the pear or quince on the apple, but the pear or quince, as also the medlar, will grow on each other; Mr. Miller therefore thinks they ought to have different genera.

$\S$ In aizoon the essential character consists in the stamina being inserted by gets or phalanxes into the sinuses of the calyx (commonly by threes approximated); not, equally distributed on the receptacle. 


\section{ORDER V. POLYGYNIA.}

\section{(MANY FEMALES.)}

No Genera. Growth. Species. Native of Species in Calyx five-cleft.

25 Rosa*

26 Rubus s 21 France, Carolina Brit. 5 s \& h 20 ,W. Indies, Canada Brit. 5

\section{Calyx eight-cleft.}

27 Dryas

h 2 Kamschatka

h 2 Europe

Brit. 1

28 Tormentillat

\section{Calyx ten-cleft.}

$\begin{array}{lllll}\text { 29 Calycanthus, scaly } \text { s \& h } & 2 & \text { Carolina, Virginia } & \\ \text { 30 Comarum } & \text { h } & \text { 1 } & \text { Dantzick } & \text { Brit. 1 } \\ \text { 31 Fragariaf } & \text { h } & 3 & \text { France } & \text { Brit. 2 } \\ \text { 32 Geum } & \text { h } & \text { 8 } & \text { Virginia } & \text { Brit. 2 } \\ \text { 33 Potentilla\|l } & \text { s \& h } 31 \text { Canada, Norway } & \text { Brit. 8 }\end{array}$

* Rosa spinosissima (the dwarf Scotch rose) is the least of the rose kind, seldom rising above a foot or two in hight.

+ Tormentilla from the number of stamina (being sixteen) appears to belong to the class dodecandria, but all the other characters being agreeable to this class overrule the number of stamina. The root (which is one of the strongest vegetable bitters) hath been frequertly used for tanning leather, and is said to be equal to oak bark. See polygonum bistorta.

¿Linnæus makes only three species of the strawberry, (viz.) fragaria vesca, monophylla, and sterilis; but of the first there are many varieties; which, as named by Aiton, are fragaria vesca sylvestris, wood strawberry; fragaria vesca pratensis, hautboy strawberry; fragaria vesca chiloensis, Chili strawberry; fragaria vesca virginiaca, scariet or Virginian strawberry ; fragaria vesca ananus, pine strawberry, with varieties, as from Carolina, \&c. The strawberry is not properly a lerry, for the seeds are disposed upon the surface; therefore Linnæus calls it a pulpy berried receptacle of the seeds. In planting strawberries, care should be taken to have the sets from good bearing young plants; for the old often become barren, or what the gardeners term blind, in which case there will be found an imperfection in the stamina or pistilla, and Mr. Miller says this is very common to plants that have creeping roots or stalks. The strawberry propagates itself by wires above ground, as the potatoe does by wires below ground.

§ The roots of avens or herb-bennet (geum) smell somewhat like cloves; hence this genus was known by the name of caryophillata in the time of Pliny.

II In potentilla take away one fifth part of the number, in the several parts of the fructification, and you will have tormentilla. 


\section{CLASS XIII. POLYANDRIA. \\ (MANY STAMINA OR MALES.)}

The flowers of this class are furnished with many stamina, (above twenty) inserted into the common receptacle. From this invariable character, is this class distinguished from the preceding class, icosandria; which is very necessary to observe, as the fruits of this class are frequently poisonous.

This class contains eight orders.

\section{ORDER I. MONOGYNIA.}

(ONE FEMALE.)

No Genera. Growth. species. Native of $\quad \begin{gathered}\text { Species in } \\ \text { Britain. }\end{gathered}$

1st. One-petaled.

1 Alstonia*

2 Marcgravia

3 Rittera

4. Ternstroemia

5 Trilix

6 Rheedia

s 1 America

s 1 W. Indies

1

1

2d. Three-petaled.

s 1 Carthagena

3d. Four-petaled.

Calyx nōne.

$\mathrm{s}$ 1. America

Calyx one-leaved.

7 Legnotis

h 1

* See symplocos. 
No of

No Genera. Growth. species. Native of

Species in

\section{Calyx two-leaved.}

$\begin{array}{rrrll}8 \text { Chelidonium* } & \text { h } & 5 & \text { Italy, Japan } & \text { Brit. } 4 \\ 9 \text { Mammea } & \text { t } & 1 \text { America } & \\ 10 \text { Papavert } & \text { h } & 9 & \text { Alps, Oriental } & \text { Brit. } 6\end{array}$

Calyx four-leaved, or four-cleft.

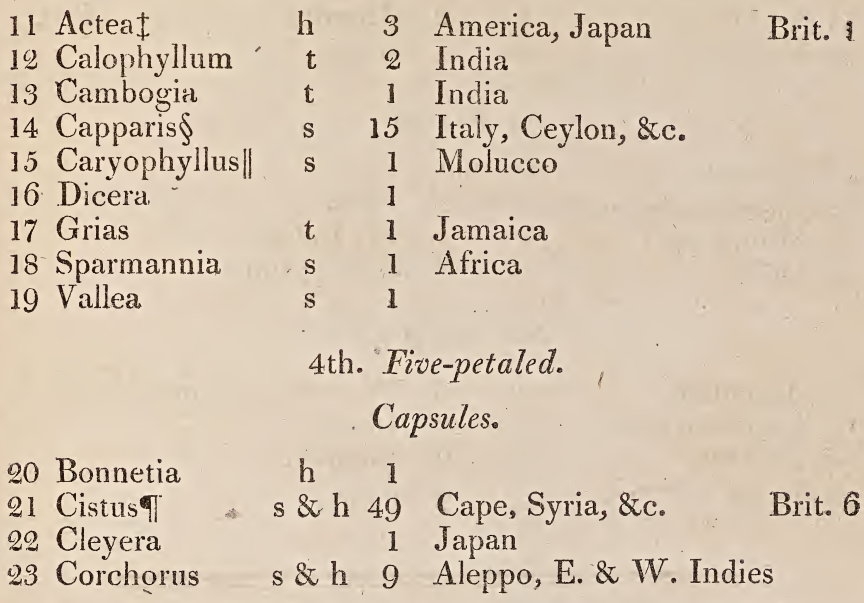

* In chelidonium (the horned poppy species) after the stamens have performed their office, the pistil elongates to upwards of a foot (whence the name horned) filled with small seeds.

+ Opium is extracted from the leaf, stalk, and head of the papaver somniferum, of which there are some varieties; but is not found in the seed.

¥ The berries of actea are said to be of a very noxious quality.

\$The capers that are used as a pickle, are the full grown flower-buds of the capparis spinosa; and are chiefly brought from Italy.

\| The spice called cloves, are the flowers of the clove tree (caryophyllus aromaticus) got before expansion and dried.

T Ladanum or labdanum (cistus ladaniferus) is collected in a particular manner; it is gently brushed off the leaves of the shrub in a calm day, with a sort of brush or whip composed of many leather straps, to which it adheres, and from which it is scraped off, and made into cakes; it is also often taken from the beards of the goats, that brouze on these shrubs. 


\begin{tabular}{|c|c|c|c|c|}
\hline Genera. & Growth. & $\begin{array}{l}\mathrm{N}^{\circ} \text { of } \\
\text { species. }\end{array}$ & Native of & $\begin{array}{c}\text { Species in } \\
\text { Britain. }\end{array}$ \\
\hline 24 Loosa & $\mathrm{h}$ & 1 & Peru & i \\
\hline 25 Lemniscia & $\mathrm{h}$ & 1 & & \\
\hline 26 Mentzelia & & 1 & America & \\
\hline 27 Myrodendrum & h & 1 & (n) & \\
\hline 28 Sarracenia & h & 2 & America & \\
\hline gy Sloanea & s & 2 & Brasils & \\
\hline S0 Sterbeckia* & h & 1 & & \\
\hline$\$ 1$ Tiliat & $\mathbf{t}$ & 2 & America & Brit. I \\
\hline 32 Vateria & s & 1 & India & \\
\hline
\end{tabular}

\section{Berries.}

83 Ascium
34. Elæocarpus, drupe
35 Muntiugia
36 Ochna

$\begin{array}{lll}\mathrm{h} & 1 & \\ \mathrm{~s} & 2 & \text { India } \\ \mathrm{t} & 1 & \text { W. Indies } \\ \mathrm{t} & 2 & \text { Africa, India }\end{array}$

\section{5th. Six-petaled.}

$\begin{array}{lrll}37 \text { Argemone } & \text { h } & 3 \text { W. Indies, Armenia } \\ 88 \text { Lagerstræmia } & \text { t } & 2 \text { India } \\ 39 \text { Lecythis } & \text { s } & 2 \text { America } \\ 40 \text { Theat }\left\{\begin{array}{l}\text { bohea, } \\ \text { viridis }\end{array}\right\} & \text { s } & 2 \text { China }\end{array}$

* Sterbeckia hath three or five petals.

+ An infusion of the blossoms of the tilia (lime tree) is in much esteem in the south of France, for coughs, hoarsenesses, fevers, \&c.; it is a very soft, well-flavoured, pleasant saccharine juice, in taste murh resembling the juice of liquorice. (White's Naturalist's Calendar, 1795). Pliny also mentions a papyrus made of the bark of the philyra, being the antient name for tilia.

I The article tea (thea) hath employed the conjectures of many writers, and yet the real plant scems not clearly ascertained, or, at least, how it is managed by the cautious Chinese. Linnæus makes two species, bohea and viridis; the bohea tea is described as having six petals, and the green tea nine petals : but it is now said that Linnæus received wrong information, and that it is only one species, which Aiton calls thea bohea, which hath six petals, and two varieties, one with broad leaves, and the other with narrow leaves; and it is said that the different flavours and colours are owing to the manner and time of gathering the leaves, and mode of drying and curing; and some use a mixture of different plants (perhaps the olea fragrans, or camellia japonica, \&c.) as may be seen by the different shape of the leaves in the tea we buy. In Sir George Staunton's account of China, it is said 18,000,000 pounds of tea are consumed annually in England, Scotland, and Ire. land; above 5,000,000 of which are said to be manufactured in England. 


\begin{tabular}{|c|c|}
\hline No Genera. & $\begin{array}{l}\begin{array}{l}\text { No of } \\
\text { Growth } \\
\text { species. Native of }\end{array} \\
\text { 6th. Eight-petaled. }\end{array}$ \\
\hline 41 Sanguinaria & h 1 Canada \\
\hline & 7th. Nine-petaled. \\
\hline 2 Podophillum & h 2 America \\
\hline- & 8th. Ten-petaled. \\
\hline Bixa* & 1 W. Indies \\
\hline
\end{tabular}

44. Nymphæa

h 7 India

6th. Eight-petaled.

$$
\text { 7th. Nine-petaled. }
$$

8th. Ten-petaled.

$$
\text { 9th. Many-petaled. }
$$

10th. Without petals.

$$
\text { Calyx three-leaved. }
$$

45 Prockia

46 Trewia

$\begin{array}{ll}8 & 1 \\ & 1\end{array}$

$$
\text { Calyx fire-leaved. }
$$

47 Delima

48 Lætia

49 Seguieria

$\begin{array}{lll}\mathrm{s} & 1 & \text { Ceylon } \\ \mathrm{s} & 2 & \text { America } \\ \mathrm{s} & 1 & \text { America }\end{array}$

ORDER II. DIGYNIA.

(TWO FEMALES.)
50 Calligonum $\uparrow$

5) Curatella

s 1 Mount Ararat
s 1 America

Brit. 2 


No Genera.
52 Euryandra
53 Fothergilla
54 Lacis
55 Pronia*
56 Trilocarpus

$$
\text { No of }
$$

Growth. species. Native of

Species in Britain.

\title{
ORDER III. TRIGYNIA。
}

\author{
(THREE FEMALES.)
}

57. Aconitum
58 Delphinium
59 Homalium

$$
\begin{array}{lll}
\text { h } & \text { 7 } & \text { Alps, Stiria, \&c. } \\
\text { h } & 9 & \text { Siberia } \\
\text { h } & \text { l } &
\end{array}
$$

Brit. 1

\section{ORDER IV. TETRAGYNIA.}

$$
\text { (FOUR FEMALES.) }
$$

$\begin{array}{llll}\text { 60 Caryocar } & \text { s } & 1 & \text { Barbary } \\ 61 \text { Cimicifuga } & \text { s } & 1 & \text { Siberia } \\ 62 \text { Tetracera } & \text { s } & 1 & \text { W. Indies }\end{array}$

\section{ORDER V. PENTAGYNIA.}

$$
\text { (FIVE FEMALES.) }
$$
63 Aquilegiat
h 5 Canada
Brit. of
64. Brathys
S 1 New Cranada
65 Nigellat
66 Reaumuria
h 5 France, Spain, \&c.
h 1 Egypt

* In preonia the most natural number of germens are two, but different species have from two to five: The one is called male pceony, as having stamina; the other female, as having no stamina, from its luxuriance. Poonia moutan (the Chinese tree paony) is a beautiful plant when in flower.

+ Aquilegia vulgaris (common columbine) of which there are great varieties.

I In nigella damascena (fennel flower, or devil in the bush) the females are very tall compared to the males; and binding over in a circle to them, give the flower some resemblance to a regal crown. 


\section{ORDER VI. HEXAGYNIA.}

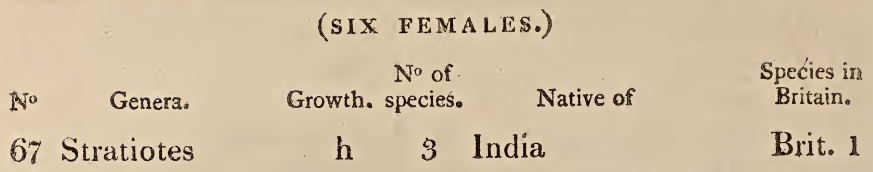

ORDER VII. DECAGYNIA.

(TEN FEMALES.)

68 Brasenia

h 1

ORDER VIII. POLYGYNIA.

(MANY FEMALES.)

Calyxes none.

69 Atragene

70 Anemone*

71 Caltha

72 Clematis

73 Helleborust

74. Hydrastis

75 Isopyrum

76 Thalictrum

77 Trollius

$\begin{array}{rrll}\text { s } & 5 & \text { Alps, Ceylon, Cape } & \\ \text { h } & 28 & \text { Alps, America } & \text { Brit. 4 } \\ \text { h } & 1 & \text { Europe } & \text { Brit. 1 } \\ \text { s } & 15 & \text { Virginia, Japan } & \text { Brit. 1 } \\ \text { h } & 5 & \text { Italy } & \text { Brit. 2 } \\ \text { h } & 1 & \text { Canada } & \\ \text { h } & 3 & \text { Siberia } & \\ \text { h } & 21 & \text { Alps, Siberia, \&c. } & \text { Brit. 3 } \\ \text { h } & 2 & \text { Asia, Europe } & \text { Brit. 1 }\end{array}$

Calyxes three-leaved.

78 Arnonaf

79 Liriodendron $\begin{array}{lll}\mathrm{t} & 9 & \text { Asia, Africa } \\ \mathrm{t} & \mathrm{g} & \text { Virginia }\end{array}$

* Anemone hath in general no calyx, but the anemone hepatica hath a three leaved perianth. Pliny says this flower never opens its petals but when the wind blows; whence its name.

+ In the hellelorus niger (Christmas rose) the petals are white till the seed is impregnated, they then change into green, forming a kind of calyx.

F Custard apple (annona reticulata) is in high repute in Jamaica and other West India islands; and is of the same genus with the famous fruit so much cultivated in Peru, in South America, (viz. annona squamnsa) called by the Spaniards chirimoya, and is said to be one of the most delicious fruits in the world. See note to garcinia. 


No Genera.
80 Magnolia
81 Michelia
82 Unona
83 Uvaria
84 Wintera

85 Houtuynia
$N^{\circ}$ of

Growth, species.
Species in Britain.

$$
\begin{array}{lll}
\mathrm{t} & 4 & \text { Virginia } \\
\mathrm{s} & 2 & \text { India } \\
& 1 & \\
\mathrm{~s} & 2 & \text { Ceylon, Java } \\
\mathrm{s} & 2 & \text { Granada }
\end{array}
$$

Calyxes four-leaved.

$$
1 \text { Japan }
$$

Calyxes five-leaved.

$\begin{array}{lrrlr}86 \text { Adonis } & \text { h } & \text { y Cape, \&c. } & \text { Brit. I } \\ \text { 87 Aubletia } & \text { h } & 1 & \\ \text { 88 Dillenia } & \text { s } & \text { 1 India } & \\ \text { 89 Ranunculus* } & \text { h } & 59 \text { Crete, Asia, \&c. } & \text { Brit. 12 } \\ & \text { Calyxes six-leaved. } & \\ \text { 90 Illicium } & \text { s } & \text { 2 China }\end{array}$

* In ranunculus the essence consists in the nectary, all other parts of the fructid fication are inconstant ; the nectary is a pit in each petal above the claws. Some of the species of ranunculus are acrimonious and deleterious, especially the ranun culus bulbosus, and ranunculus sceleratus. The butter-cups or crow-foots in our meadows are of three species, viz. 1st. ranunculuis bulbosus (bulbous) hath the calyx turned hack to the flower-stalk, the peduncles furrowed, and a bulbous root.-2d. ranunculus repens (creeping) hath the calyx open or spreading, the peduncle furrowed, and puts out runners like the strawberry.-3d. ranunculus acris (acrid) hath the calyx open and spreading, the peduncle round, and grows the highest. 


\section{CLASS XIV. DIDYNAMIA.}

\section{(TWO POWERS.)}

The flowers of this class are furnished with four stamina, two of which are long, and two short; which is the essential character of this class. The two shorter stamina stand nearest to, and approaching the style of the pistillum, received within an irregular corrolla.-The flowers of this class are generally a little inclining from the stem, that the corolla may more easily cover the antheræ, and that the pollen may fall on the stigma, and not be injured by rain.-This class comprehends the virticiled or whorled plants, the lipped, the masked, and the grinning or ringent flowers of other authors; and in general admits of the following natural character :

Calyx. A perianthium of one leaf, erect, tubular, with five clefts, segments unequal; permanent with the fruit.

Corolra. One petal, nearly erect, the base tubular, containing honey, and doing the office of a nectarium. The border generally ringent (gaping); the upper lip straight, the lower lip expanding, with three clefts, the middle cleft broadest.

Stamina. Four filaments, awl-shaped, inserted into the tube of the corolla, and inclined towards the back thereof, the two inner and nearest to the pistillum being shorter*; they are all parallel, and seldom exceed the length of the corolla. The antheræ are generally covered by the upper lip of the corolla, and approach each other so as to stand in pairs.

Pistrulum. The germen generally above the receptacle. The style single, thread-shaped, bent in the same manner as the filaments, and usually placed in the midst of them, but rather longer, and a little curved towards the summit. The stigma is generally end-nicked.

* See the reason why they are shorter, in the explan, of the class tetradynamiø. 
Pericarpium. Either none, as in the first order gymnospermia; or, if present, as in the second order angiospermia, it generally consists of two cells.

SEMINA. Either four (if no pericarpium) situated in the bottom of the calyx as in a capsule; or, if" a pericarpium, there are generally many, fixed to a receptacle placed in the middle of the pericarpium.

This class contains two orders.

\section{ORDER I. GYMNOSPERMIA.*}

\section{(SEED-NAKED.)}

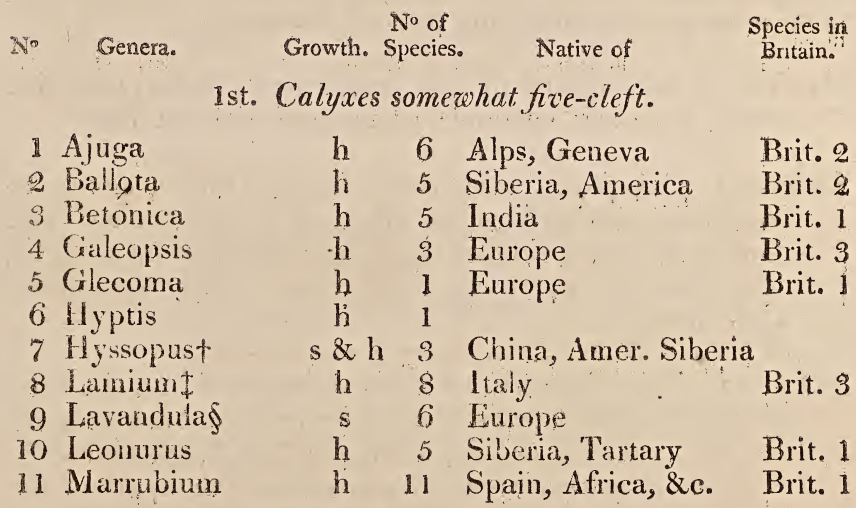

* The plants of this order are scented, and said to be cephalic and resolvent ; the virtue is in the leaves. None are poisonous.-And the seeds are said to be naked; as not being lodged in a capsule, but are situated in the bottom of the calyx.

+ Common hyssop (hyssopus officinalis) of which there are four varieties, is much recoinmended in bruises; by applying a boiled cataplasm of the leaves, it both takes off the pain and blackness. It is also good in an asthma, \&c.

$\mp$ In Linnæus's description of the specific character of the white archangel (lamium album) he says the verticils have twenty flowers, but in England I have examined several, and have not found twenty.

§ From lavender (lavendula) is obtained an oil, called oil of spike; which is brought chiefly from France, where lavender is called espic. 
$N^{\circ}$ of

No Genera.

$N^{\circ}$ of

Growth. Species. Native of

Species in

12 Mentha*

$\begin{array}{rrl}\text { h } & 20 & \text { Canada, Austria } \\ \text { h } & 3 & \text { Syria }\end{array}$

Britain.

13. Moluccella

14 Nepeta

15 Perilla

16 Phlomis

17 Satureja

18 Sideritis

19 Stachys

20 Teucrium

h 18 Italy, \&c.

Brit. 12

h 1 India

h 13 Ceylon, India

s \& h 8 France, Greece

h 13 Canary, Syria

h 17 Germany, Alps, \&c. Brit. 4

s \& h 35 America, \&c. Brit. 4

\section{2d. Calyxes two-lipped.}

21 Cleonia
22 Clinopodium
23 Dracocephalum
24 Horminum
25 Melissa
26 Melittis
27 Ocymumt
25 Origanum
29 Phryma
30 Prasium
31 Prunella

\section{h}

h

h

h

s \& $\mathrm{h}$

h

h

h

h

s

h
1 Portugal

3 America

Brit. 1

13 America, Siberia

1 Pyrenia

6 Crete

Brit. 2

Brit. 1

1 Germany

Brit. 2

11 Egypt, Syria,

2 S. America.

2 Spain, Sicily

3 Europe

Brit. 1

Brit. 1

*W. Sole, a medical practicer at Bath, hath lately published a treatise on mints, or rather ments, (mentha) 1798, pr. $£ 1$. 1s. with plates. He hath adopted the subdivision of the genus from Linnaus; 1 st. into spilsed mints, of which he makes eight species; $2 \mathrm{~d}$. into round-headed, containing four species; $3 \mathrm{~d}$. into whorled, containing twelve species.-The common spear mint (mentha viridis) is of the spiked species. - The pepper mint (mentha piperita) Linnæus describes as one of the round-headed species, put Mr. Sole makes three varieties, viz. 1st. mentha piperita officinalis, the true pepper mint, which is spiked, and lanceolate leaves.2d. mentha piperita vulgaris, common pepper mint, which is round-headed, and hath ovate leaves : and 3.d. mentha piperita silvestris, wild pepper mint, which is spiked, and hath broad ovate leaves; this is larger and coarser than the two former, and hath a disagreeable smell.

tThe Abbe Gruvel, in his history of Chili, (translated from the Italian of the Abbe Molina, 1788) mentions a species of basil in the province of St. Jago, which he calls ocymum salinum, and says it greatly resembles the common basil, except that the stalk is round and jointed; but what is remarkable in this plant is, that though it grows sixty miles from the sea, yet every morning it is covered with saline globules, which are hard and splendid, appearing at a distance like dew, and that each plant furnishes about half an ounce every day, and that the peasants collect this salt and use it as common salt, to which it is superior in flavour. 
Nio Genera.

32 Scutellaria

83 Thymbra

34. Thymus

35 Trichostema

$\begin{array}{crll}\text { Growth. } & \begin{array}{l}\text { No of } \\ \text { species. Native of }\end{array} & \begin{array}{c}\text { Species in } \\ \text { Britain. }\end{array} \\ \text { h } & 15 & \text { Italy, Havannah, \&c. Brit. 2 } \\ \text { h } & 2 & \text { Macedonia } & \\ \text { h } & 13 & \text { America, Alps } & \text { Brit. } \\ & 2 & \text { N. America } & \end{array}$

\section{ORDER II. ANGIOSPERMIA.}

(SEED-COVERED.)

1st. Calyxes gaping.

$\$ 6$ Castilleja
h 2 New Granada

2d. Calyxes two-cleft.

Capsules.

37 Acanthus

38 Alectra

39 Dombeya

40 Hebenstretia

41 Obolaria

42 Orobanche

43 Torenia

h 10 Italy, Cape, \&c.

\begin{tabular}{lll} 
& 1 & \\
h & 1 & \\
h & 5 & Ethiopia \\
h & 1 & Virginia \\
h & 9 & Virginia \\
\hline & 1 & Asia
\end{tabular}

Berries.

44 Crescentia

45 Premna

$\mathrm{t} 22$ Jamaica

s, 2 E. Indies

3d. Calyxes three-cleft.

46 Halleria

1 Ethiopia

4th. Calyxes four-cleft.

47. Lippia

48 Matourea

49 Selago

50 Taligabea

51 Lathræa $\mathrm{t} 4$ America

h 1

s 19 Ethiopia, \&c.

s 1

Capsules one-celled.

h 4 France
Brit. \& 
No Genera. Growth species. Native of
No of

Capsules two-celled.

52 Barleria

53 Bartsia

54. Euphrasia

55 Hemimeris

56 Melampyrum

57 Rhianthus

58 Schwalbia

59 Loecelia

60 Gmelina

61 Lantana

62 Avicennia

63 Browallia

64. Conobea

65 Gloxinia

66 Limosella

67 Lindernia

68 Myoporum

69 Piripea

70 Tozzia

71 Vandellia

79 Antirrhinum

73 Bignonia

74. Buchnera

75 Capraria** h 10 India, Jamaica

h 5 Alps

h 7 Europe

h 3 Cape

h 5 Europe

h 7 Cape, Virginia

1 America

Brit. 2

Brit. 2

Brit. 4

Brit. 1

Capsules three-celled.

\section{La-Vera-Crux}

Drupes two-celled.

s 1 Asia

s 9 W. Indies, Africa

5th. Calyxes five-cleft.

Capsules one-celled.

\begin{tabular}{|c|c|}
\hline 2 & Martinico \\
\hline 3 & S. America \\
\hline 1 & \\
\hline $\begin{array}{l}1 \\
2\end{array}$ & $\begin{array}{l}\text { S. America } \\
\text { Europe }\end{array}$ \\
\hline 2 & Virginia, Japan \\
\hline 1 & \\
\hline l & \\
\hline 1 & Alps \\
\hline 1 & St. Thomas \\
\hline
\end{tabular}

Capsules two-celled.

h 47 America, Alps

Brit. 10

t \& s 22 America, India, Peru

h 9 America, Asia

s 5 W. Indies

* Capraria lifiora is the tea plant of St. Domingo; it is an evergreen shrub, the Waves of which are employed by the inhabitants of the Antilles for the same puspose as the tea of China and Japan. 


\begin{tabular}{|c|c|c|c|c|}
\hline Genera. & Growth. & $\begin{array}{l}\text { No of } \\
\text { speciés. }\end{array}$ & Native of & $\begin{array}{l}\text { Species ity } \\
\text { Britain. }\end{array}$ \\
\hline 76 Celsia & hi & 3 & Crete & \\
\hline 77 Chelone & $\mathrm{h}$ & 5 & N. America & \\
\hline 78 Columnea & hr & 2 & Martinico, E. Indies & \\
\hline 79 Digitalis* & $\mathrm{s} \& \mathrm{~h}$ & 9 & Canary & Brit. 1 \\
\hline 80 Dodartia & h & 2 & Mount Ararat & \\
\hline 81 Erinus & h & 7 & Alps, Africa, Peru & \\
\hline 82 Gerardia & $\dot{\mathrm{h}}$ & 10 & Virginia, Japan & \\
\hline 83 Gesneria & $\mathrm{s}$ & 3 & Jamaica & \\
\hline 84 Manulea & h & 17 & Cape, \&c. & \\
\hline 85 Mimulus & h & 2 & Virginia, Peru & \\
\hline 86 Montira & h & 1 & & \\
\hline 87 Pedicularis & h & 17 & Canada, \&c. & Brit. $\mathscr{A}$ \\
\hline 88 Penstemon & $\mathrm{h}$ & 2 & S. America & \\
\hline 89 Petrea & s & 1 & S. Am'erica & \\
\hline 90 Ruellia & h & 21 & W. Indies, Japan & \\
\hline 91 Scrophularia & $\mathrm{hi}$ & 17 & N. America & Brit. 4 \\
\hline 92 Sesamum & $\mathrm{h}$ & 2 & India & \\
\hline 93 Sibthorpia & $\mathrm{h}$ & 2 & Africa, Europe & Brit."1 \\
\hline 94. Stemodia & h & 1 & Jamaica & \\
\hline
\end{tabular}

Capsules five-celled.

95 Craniolaria

96 Martynia

97 Amasonia

98 Pedalium
\& \& h 2 W. Indies

h 3 S. America

\section{Nut one-celleds}

h. I Surinam

Nut two-celled.

h 1 Ceylon

Berry one-seeded.

$\begin{array}{lllll}99 & \text { Bontia } & \mathrm{s} & 1 & \text { Antilles } \\ 100 \text { Clerodendron } & \mathrm{s} & 6 & \text { India } \\ 101 & \text { Cormutia } & \mathrm{s} & 1 & \text { W. Indies }\end{array}$

* Digitalis popurea (foxglove) is much recommended in some species of dropsy, but it must be given with caution.

Botanic Garden. 
No of

No Generá. Growth. Species.

Native of

Species in

Berry two-seeded.

102 Citharexylon

103 Ovieda

t 3 W. Indies

s 2 W. Indies

104 Volkameria

s 5 Jamaica, Japan

Berry three-celled, dry.

105 Linnæa*

s 1 Siberia, Canada

Berry four-seeded.

106 Duranta

107 Vitex

3 W. Indies

s 7 Sicily, \&c.

Berry many-seeded.

108 Besleria

h 4. America

Siliqua.

109 Millingtonia s 1

6th. Calyxes many-cleft.

Capsules two-celled.

110 Cymbaria

111 Hyobanche

112 Thunbergia

113 Melianthus h 1 Dauria

h 1 Cape

h. 1 Cape

7th. Many-petaled.

h 2 Ethiopia

* This plant (Linnæe lorealis) Linnæus took for a crest to his coat of arms; the flowers appear in June and July, are bell-shaped, white without, and red within, and somewhat hairy, and have a pleasant smell, especially in the evening. In Tronheim and the neighbouring parts, it is drank as tea for medicinal purposes. 


\section{CLASS XV. TETRADYNAMIA.*}

(FOUR POWERS.)

The flowers of this class are furnished with six stamina, four of which are long and two short. It corresponds with the siliquos a of Ray, and the cruciformes of Tournefort. This class (except in one genus, cleome, in which the stamina, in many of the species, are joined to a footstalk supporting the germen, and ought therefore rather to belong to the class gynandria) is truly natural; and admits of the following character :

Calyx. A perianthium, oblong, consisting of four leaves, oblong-egg-shaped, concave, blunt, converging, gibbous at the base, standing opposite in equal pairs, deciduous with the corolla. The nectarium is a part of, and formed in the calyx, and often occasions it to be gibbous.

Corolla. Four petals, cruciform, equal; claws flattish, awlshaped, erect, rather longer than the calyx, limb or border flat, the laminæ broadest towards the end, blunt, the sides scarcely touching each other. The insertion of the petals is in the receptacle along with the stamina.

Stamina. Filaments six, fixed in the receptacle, awl-shaped, erect; of which the two shorter, that are opposite, are as long as the calyx; the other four rather longer, but not so long as the corolla. The antheræ rather oblong, taper, thicker at the base, erect, the tops bending outwards.

The nectaria are glands, which appear different in different genera; they are seated on the stamina, and are fixed on the inside of the base of the shorter filaments, which are generally bent, that they may not press upon the glands of the nectaria; and they thereby appear shorter than the others; but they are fixed on the out side of the base of the longer stamina, as in sinapis, \&c.

* The plants of this class are held to be antiscorbutic, the taste acrid and watery: in moist and wet situations their qualities are strongest; but they lose most of their virtues by drying. None are poisonous. These plants applied externally are useful in diseases of the skin, as itch, leprosy, \&c. 
Pisticlum. Germen above, increasing daily in hight. Style, either the length of the longer stamina, or none. Stigma obtuse.

Pericarpium. A siliqua (pod) with two valves, often with two cells, opening from the base to the top; the dissepiment (partition) often projecting at the top beyond the valves; which projection had before served as a style. The siliqua is distinguished into siliquosa and siliculosa (long and short pods) which gives rise to the orders.

SEMrNA. In general many, roundish, lodged in the dissepiment (which runs lengthways) and alternately on each side: the receptacle linear, surrounding the dissepiment, and immersed in the sutures of the pericarpium.

This class contains two orders.*

\section{ORDER I. SILIQUOSA.†}

\section{(A SILIgUE.)}

Meaning such plants whose pericarpium, according to the distinction of Linnæus, is a long siliqua.

No Genera. Growth. Species. Native of $\quad \begin{gathered}\text { Species in } \\ \text { Britain. }\end{gathered}$

1st. Calyx closed with leaflets longitudinally converging.

$\begin{array}{lllll}1 \text { Arabis } & \text { h } & 11 & \text { Alps, Canada } & \text { Brit. } 3 \\ 2 \text { Brassicaf } & \text { h } & 14 & \text { Alps, China } & \text { Brit. } 5\end{array}$

* In the Gen. Plan. siliculosa is the first order, and siliquosa the second order; but in the Fragments of a Natural Method, under the order siliquosa, the siliqua is the first section, and silicula the second section, which method (as it seems more regular) I have here adopted.

+ This order admits of a few exceptions as to the long form of the seed-vessel, as in bunias, isatis, and especially in crambe, which hath a round pod, one cell, and a single seed.

¥Brassica (cabbage) greatly abounds in varieties, as brocoli, cauliflower, \&c. And as the surface of the leaves of the family of cabbage are highly polished, there is no attraction between them and dew drops, hence the drop does not come into contact with the leaf, but hangs over it repelled, and retains its natural form, composed of attraction and pressure of its own parts, and thence looks like quicksilver : one advantage from which is, that the leaf not being moistened, is less injured by frost, and another may be that respiration is less incommoded. Botanic Garden. 


\begin{tabular}{|c|c|c|c|c|c|}
\hline No & Genera. & Growth. & $\begin{array}{l}\text { No of } \\
\text { Species. }\end{array}$ & Native of & $\begin{array}{l}\text { Species in } \\
\text { Britain. }\end{array}$ \\
\hline 3 & Chamira & & 1 & & \\
\hline 4 & Cheiranthus & h & 20 & Alps & Brit. 3 \\
\hline 5 & Dentaria & h & 3 & Italy & Brit. 1 \\
\hline 6 & Erysimum & $\mathrm{h}$ & 6 & Barbary & Brit. 4 \\
\hline 7 & Hesperis & $\mathrm{h}$ & 6 & Africa & Brit. 1 \\
\hline 8 & Raphanus & h & 5 & Siberia & Brit. 1 \\
\hline 9 & Ricotia & $\mathrm{h}$ & 1 & Egypt & \\
\hline 10 & Turritis & $\mathrm{h}$ & 3 & Alps & Brit. 2 \\
\hline
\end{tabular}

\section{2d. Calyx gaping with leaflets diverging above.}

$\begin{array}{llrll}\text { 11 Bunias } & \text { h } & 9 & \text { Egypt } & \text { Brit. 1 } \\ \text { 12 Cardamine* } & \text { h } & 15 & \text { Virginia, Africa } & \text { Brit. 7 } \\ \text { 13 Cleomet } & \text { h } & 22 & \text { Cape, Indies, Arabia } & \\ \text { 14 } \text { Crambe } & \text { h } & 5 & \text { Spain, Tartary } & \text { Brit. 1 } \\ 15 \text { Heliophila } & \text { h } & 9 & \text { Cape, \&c. } & \\ \text { 16 Isatis } & \text { h } & 4 & \text { Portugal, Egypt } & \text { Brit. 1 } \\ \text { 17 Sinapisł } & \text { h } & 17 & \text { China, \&c. } & \text { Brit. 3 } \\ \text { 18 Sisymbrium } \oint & \text { h } & 29 & \text { India, \&c. } & \text { Brit. 7 }\end{array}$

* The cardamine pratensis (lady's smock) made into strong tea, whether in the green or dry state, and to be the only drink, is said to be a sovereign remedy for convulsions in children.

In many of the species of cleome, there are more than six stamina, and not always unequal as to length; that the only reason for introducing this genus to this class, is the nectariferous glands, being three, placed at each division of the calyx, except one; yet are often so very small, as scarcely to be discovered by glasses.

† The seed of the sinapis arvensis (charlock or ketlock), according to Mr. Miller, is commonly sold under the title of Durham mustard. The common mustard is from the sinapis nigra, and grows four or five feet in hight.

§isymbrium nasturtium (water cress) is much admired as a sallad at Spring, and is said to be preferable to all others against the scurvy; but as some people have suffered by mistaking the creeping water parsnip for the true water cress, it may not be improper to give a short description of both.-The sisymbrium nasturtium is of the class and order tetradynamia siliquosa, hath the pod declining, leaves feathered, leaflets somewhat hearted; the small leaves have few indentures on the edges, are of a dark green, with a tincture of brown upon them, and the odd one at the end very large and roundish.-The sium nodiflorum (creeping water parsnip) is of the class and order pentandria digynia, hath the leaves feathered, umbels axillary sessile, the small leaves oblong, pointed, serrated on the edges, and are of a light green. 


\section{ORDER II. SILICULOSA.}

\section{(A SILICLE.)}

Meaning such plants whose pericarpium is a little or short siliqua (called silicula), and is either flat or turgid.

No Genera. Growth. $\begin{aligned} & \text { No of } \\ & \text { species. Native of }\end{aligned}$

1st. Silicle entire, not end-nicked at top.

$\begin{array}{llrll}\text { 19 Draba } & \text { h } & 9 \text { Alps } & \text { Brit. } 3 \\ \text { 20 Lunaria } & h & \text { \& } & \text { Hungary } & \\ \text { 21 Myagrum } & \text { h } & \text { 10 Spain, \&c. } & \text { Brit. 1 } \\ \text { 22 Subularia } & \text { h } & \text { 1 Europe } & \text { Brit. 1 } \\ \text { 23 Vella } & \text { h } & \text { 2 Spain } & \text { Brit. 1 }\end{array}$

2d. Silicle end-nicked at top.

24. Alyssum

25 Anastatica*

26 Biscutella

27 Clypeola

28 Cochlearia

29 Iberis

30 Lepidium

31 Peltaria

32 Thlaspi
s \& h 17 Spain, Alps, Crete
h 1 Jericho, Syria
h 6 Italy
h 3 Italy
h 8 Denmark, Greenland Brit. 6
s \& h 13 Gibraltar, \&c. Brit. 2
h 20 America, Alps Brit. 4
h 2 Cape
h 12 Alps, Europe Brit. 6

\footnotetext{
* Anastatica hierochuntica (rose of Jericho) was formerly called by the monks rosa marix, who made a miracle of the flower opening in the form of a cross on the night that our Saviour was born.-The fact is this; according to $\mathrm{Mr}$. Miller, the flower consists of four small petals of a whitish green colour, which open in the form of a cross, like the other genera of this class; it is a low annual plant, dividing into many irregular woody branches, which being dried, may be preserved many years, and at any time being set two or three hours in water, will dilate and open so as to disclose the seed vessels and seed.-For this singular circumstance it is preserved in the cabinets of the curious. It is said that Lord Trimbleston has one that hath been in the family above seventy years, and still possesseth this remarkable property.
} 


\section{CLASS XVI. MONADELPHIA.*}

\section{(ONE BROTHERHOOD.)}

The flowers of this class have their stamina in one set, that is, they are united at the base into one circular body, in the midst of which standeth the pistillum.

The genera of this class have been variously distinguished by different botanists; some by the petals, others by the fruit and leaves of the plant, but Linnæus found the best and most infallible distinction to be in the calyx, which in the last order is generally double.

This elass hath the following natural character:

Calyx. A perianthium always present, permanent, and in many genera double.

Corolla. Petals five, or five divisions, generally inversely heart-shaped, the sides of which fold one over the other from the right to the left, contrary to the motion of the sun.

Stamina. The filaments united at the bottom, separate at the top, the exterior shorter. The anthera generally kidney-shaped, and incumbent, that is, fixed by its side leaning to the top of the filament.

Pistillum. The receptacle of the fructification is prominent in the centre of the flower. The germens erect, surrounding the top of the receptacle in a jointed ring.

* The plants of this class, especially those of the order polyandria, are esteemed emollient and mucilaginous; which properties are common to every part of the plant. None are poisonous.

+ In some plants the separation is not to be effected without a pin or needle, as in hiliscus, (althæa) \&c.-They are differently situated in different genera; sometimes on the receptacle, as in barringtonia; sometimes on the calyx, as in hydnora; sometimes on the coral, as in elthcea, alcea, malva, \&c. 
The styles all united at the bottom into one body with the receptacle, but separated above into as many threads as there are germens. The stigmas spreading and slender.

Pericarpium. A capsule divided into as many cells as there are pistilla; of various figures in different genera.

Semina. Kidney-shaped.

This class contains nine orders, founded on the number of stamina*.

ORDER I. TRIANDRIA.

(THREE STAMINA OR MALES.)

$\begin{array}{ccccc}\text { No } & \text { Genera. } & \text { Growth. species。 Native of } & \begin{array}{c}\text { Species in } \\ \text { Britain }\end{array} \\ 1 & \text { Aphyteia } & \text { h } & 1 & \text { Cape } \\ 2 & \text { Galaxia } & & & 2\end{array}$

\section{ORDER II. PENTANDRIA.}

(FIVE STAMINA OR MAI.ES.)

One female.

3 Buettneria

4 Erodium

5 Hydnora

6 Lerchea

7 Ochroma

8 Symphonia

9 Ticorea

10 Triguera

11 Waltheria

$\begin{array}{rrl}\text { h } & 3 & \text { Carthage } \\ \text { s \& h } & 12 & \text { Italy, \&c. } \\ & 1 & \\ \text { s } & 1 & \text { E. Indies } \\ \text { h } & 1 & \\ \text { t } & 1 & \text { Surinam } \\ \text { h } & 1 & \\ \text { s } & 1 & \\ \text { s } & 3 & \text { E. \& W. Indies }\end{array}$

Brit. 3

* In this and the two following classes, Linnæus hath thought proper to found the orders on the number of stamina only; the pistilla are only used as a dise inction of genera and species. 


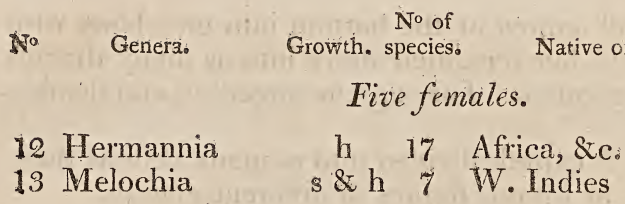

\section{ORDER III. HEPTANDRIA。}

(SEVEN STAMINA OR MALES.)

14. Pelargonium s \& h 94 Africa

\section{ORDER IV. OCTANDRIA.}

(EIGHT STAMINA OR MALES.)

15 Alchornea

16 Aitonia, one fem. s - \& Cape

17 Portesia

18 Quivisia

h 1

h 1

\section{ORDER V. ENNEANDRIA。}

(NINE STAMINA OR MALES.)

19 Dryandra

20 Quararibea

$$
\text { h } 1 \text { Cape }
$$

ORDER VI. DECANDRIA。

(TEN STAMINA OR MALES.)

One female.

$\begin{array}{llrrr}21 \text { Aquilarea } & \text { h } & \text { i } \\ 22 \text { Ciponima* } & \text { s } & 1 & \\ 23 \text { Connarus } & \text { s } & 1 & \text { India } \\ \text { 24. Chinodendron } & \text { h } & \text { l } & \end{array}$

* See symplocos, in polyadelphia. 
No of Species in

No Genera. Growth. species. Native of

25 Flabellaria

26 Geranium*

27 Molina

28 Sandoricum

29 Strigilia

h 1

s \& h 37 Italy, \&c.

Brit. 12

h. 1

h 1

h. 1

Five females.

30 Hugonia

31 Plagianthus

$\begin{array}{lll}\mathrm{t} & \mathbf{1} & \text { India } \\ \mathrm{h} & \mathbf{1} & \end{array}$

ORDER VII. ENDECANDRIA.

(ELEVEN STAMINA OR MALES.)

32 Brownea, one fem. s $\quad 1$ W. Indies

\section{ORDER VIII. DODECANDRIA.}

(TWELVE STAMINA OR MAIES.)

33 Acioa

34 Assonia h 1

35 Pentapedes, 1 fem. h 3 India

* In geranium the stamina are generally alternately long and short; this genus, according to Linnæus, hath eighty-two species under several divisions, viz. The African geraniums have only seven of the filaments that bear anthers; others have only five bearing anthers; and in others all the ten have anthers. But Mr. Aiton, in his Hortus Kewensis, hath very properly (from L. Heritier) divided the genus geranium into three genera, according to the number of stamina that bear anthers; those with five anthers he calls erodium, from erodios (an heron) containing the myrrhina of Linnæus; those with seven anthers he calls pelargonium, from pelargos (a stork) containing the Africana of Linnæus; and those with ten anthers he calls geranium, from geranios (a crane) containing the batrachia of Linnæus. But, in the 8th. edit. of the Gen. Plan. this distinction is not adopted. 


\section{ORDER IX. POLYANDRIA.}

\section{(MANY STAMINA OR MALES.)}

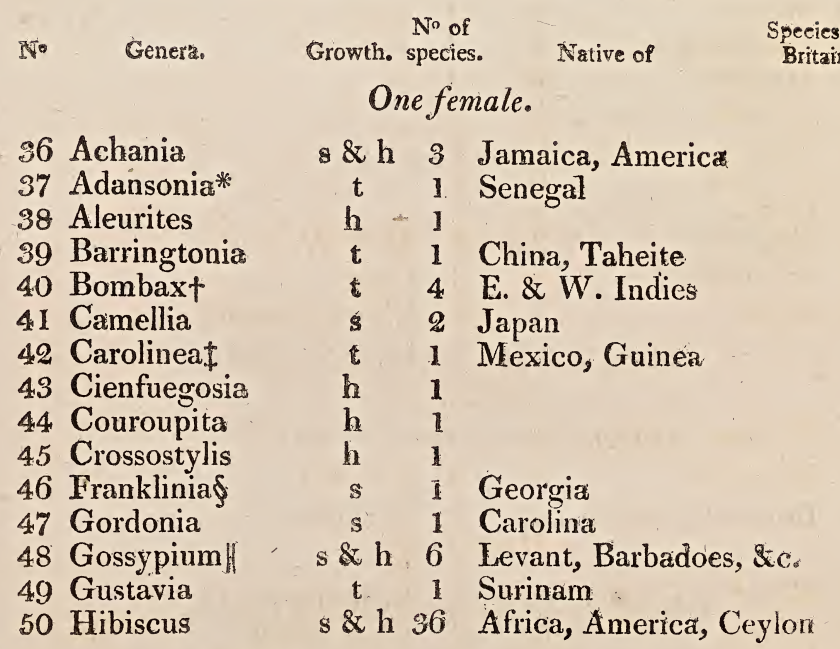

* Adansonia digitata receives its name from Mt. Adanson, who says the diameter of the trunk frequently exceeds twenty-five feet, and is supposed to be the largest tree in the world. The horizontal branches are from forty-five to fifty-five feet long, and so large as to equal the largest tree in Europe, and yet these stupendous trees do not exceed seventy feet in hight.

+ The silk-cotton tree (bombax) grows to a very large size both in the E. and BV. Indies, and the tood being very light, the trunk is chiefly hollowed for canoes. In Hispaniola it is called jaruma.

+ Carolinea omitted in the 8th. edit. of Gen. Plan.

\$Franklinia alatamaha is said to be a new genus, (though nebrly allied to gor: donia) its trivial name is taken from a river in Georgia, where it was found native; it is a beautiful flowering tree-like shrub, rising about twenty feet; the flower is often five inches in diameter, consisting of five petals, with a tuft or crown of yellow stamina, and hath the fragrance of a China orange. Franklinia is not in the 8th edit. of Geny Plan.

II The cotton from the Levant is said to be from the gossypizm herlaceum; it is sown in Spring, and is ripe in about four months: That from the $E_{0}$ and $W$. Indies is from a shrub. 
MONADELPHIA.

No of

No Genera

Growth. species. Native of

Species in

51 Laguna

52. Malvaviscus

53 Mesua

54 Morisonia

55 Myrodia

56 Pachira

57 Palava

58 Pavonia

59 Ruizia.

60 Sida

61 Solandra

62 Urena
s 1
h 1
s 1 India
s 1 America
h 1
h 1
h 1
h 1
s 1
i \& h 27 E. \& W. Indies
s 1 Cape
s 6 China, America

Five females.

63 Malochodendron h 1

64 Stewartia s i Virginia

\section{Many females.}
65 Alcea*
66 Althæa
67 Lavatera
68 Malachra
69 Malope
70 Malva

h 2 E. Indies

h 4 Italy, Spain Brit. 1

s \& h 9 America, Crete Brit. 1

$\mathrm{s} 2$ Caribees

h 1 Hetrurea

s. \& h 26 Amer. Peru, Cape Brit. 5

* Alcea (hollyhock) omitted in the 8 th edit. of Gęn.Plan. by Thaddæus Haenke, and seems to be placed under althoea. 


\section{CLASS XVII. DIADELPHIA.*}

(TWO BROTHERHOODS.)

All the flowers of this class are supposed to have their stamina in two sets or bodies, severally united at the base: yet though this is the general classic character, we are not to imagine it is invariable ; for under the first distinction of the last order, the plants are monadelphious, that is, all the stamina are connected; also the two sets of stamina in the last order, are often to be traced with difficulty, for only one of the sets are properly united, the other consisting only of a single filament, which in most plants adheres so closely to the united set, that it cannot be separated without the application of a pin or needle for that purpose, in some you cannot by this means effect a separation. Therefore the plants of this class are more easily ascertained by their papilionaceous corolla, (resembling a butterfly) with stamina united at the base, $\uparrow$ and other parts of the fructification, especially the calyx.

This class corresponds with the leguminose of Morison, Hermannus, Boerhaave, Ray, and Roen; with the tetrapetali irregularis of Rivinus and Christopher Knaut; with the tetrapetali difformes of Christian Knaut; and with the papilionacei of Tournefort and Pontedera.

This class is truly natural, and the structure of the flowers very singular, and their situation mostly obliquely pendant; and admits of the following general characte. I

* The leaves of the plants of this class are food for cattle, and the seeds, which are farinaceous and flatulent, are food for men as well as animals. None are poisonous.

+ The papilionaceous corolla alone, is not the general characteristic of this class; as in decandria monogynia there are five plants of the same character, viz. sophora, anagyris, cercis, hymencea, and monospermum, but the stamina are distinct.-Also a species of African pelargonium hath a papilionaceous corolla.

$\mp$ The character is not exactly agreeable through the whole class, but as there are few plants but of the order decandria, it seems principally to respect that order, and particularly those genera that have nine stamina joined, and one distinct. 
CALYX. A perianthium of one leaf, bell-shaped, withering, base gibbous, the lower part annexed to the fruit-stalk, the upper part blunt, containing honey; the rim five teeth, sharp, erect, oblique, unequal; the lower tooth longer than the rest, the upper four stand in pairs, of which the uppermost pair is mostly shorter, and stands further asunder. The bottom of the calyx including the receptacle may be deeined the nectarium, as it is moistened with a sweet liquor.

Corolla. Papilionaceous, unequal, each petal having a distinct name, (viz.)

The standard, (vexillum) which is the petal covering the rest, incumbent, greater, flat, and horizontal ; inserted by its claws in the upper margin of the receptacle, approaching to a circular figure when it leaves the calyx, and nearly entire; an elevated line or ridge marking it lengthways, particularly towards the top, as if the sides were depressed. The part of the petal nearest the base is nearly the form of half a cylinder, embracing the parts that lie under it; the surface of the petal is depressed on each side, but the sides nearest to the border are reflexed; and at the unfolding of the half cylinder, are generally two concave appendages, resembling ears, prominent on the under side, compressing the wings which lie beneath them.

The wings (alæ) are two equal petals, one on each side of the flower, placed under the vexillum'; inner borders incumbent to each other and parallel, broader outward, the upper margin straighter, the lower more dilated into a roundish form; the base of each wing is cloven, the lower division being lengthened into a claw, inserted into the side of the receptacle, and is about the length of the calyx; the upper division is shorter and inflexed.

The Iieel (carina) is the lowest petal enclosing the stamina and pistillum, generally divided, placed under the standard, and between the wings, it is boat-shaped, concave, compressed on the sides, placed in the position of a vessel afloat, lessened at the base, the lower part extending into a claw as long as the calyx, and inserted into the 
receptacle; but the side and upper shorter divisions, which are cloven, are interwoven with those parts of the wings which most resemble them in shape. The keel either consists of one petal, as in cytisus, or of two adhering together, as in spartium, and is distinguished by its shape, as half-moon, spirally twisted, compressed, \&c. The sides of the keel are shaped like those of the wings, and have a similar situation, only lower and more inward. The line that forms the keel runs straight as far as the middle, and then gradually rises in an arch, but the marginal line runs straight to the end, where it obtusely joins the line of the keel.

Stamina. Are most generally ten, (placed on the receptacle*) either all united at the base, as in the first distinction of the order decandria, or nine united, and one single; the united filaments enclose the pistillum, and the single fitament is incumbent upon it. The united filaments are membranacecus below the middle, being united into a eylinder, open on one side through its whole length; along which opening lies the tenth stamen, which is called the other set, and is often so closely attached to the nine, as not easily to be separated; the membranaceous set of stamina separate upwards into nine distinct awl-shaped filaments, bent like the keel, and of the same iength, longer and shorter by pairs : the single filament is awled, or bristle-shaped, simple, and bent as the other nine, but somewhat shorter, and is detached from the rest at the base, to give vent on each side for the honey.

The anthere numbered together are ten, one upon the single filament, and one upon each of the nine divisions of the united filaments, small, equal in size, terminating.

Prsirucm. Single, placed upon the receptacle of the flower. The germen oblong, cylindrical, more or less compressed, as long as the cylinder of the united stamina, by which it is involved, and sometimes, as in erythrina, \&e. it is elevated by a slender footstalk issuing from the centre of the calyx.

* Moncidelphia, diadelphia, polyadelphia, and gynandria, are distinguished by the situation of the stamina; by which they approach nearer towards natural classes. 
The style is single, slender, awled, and generaily bent, agreeing in length and position with the stamina, withering.

The stigmat $a$ are generally covered with a beautiful down, from the part turned upwards, and placed immediatcly under the antheræ.

- Pericarpium. A legumen, oblong, more or less compressed, two valves, with a straight, longitudinal suture both above and below, yet the upper one descends near the base, and the lower one ascends near the top; and either with only one cell, or articulated (jointed) having two or more cells; opening at the upper suture; and is of various . shapes in different genera.

Semina. Generally few, smooth, and are fastened alternately along each side of one suture only, and not alternately to both; they are generally kidney-shaped, sometimes roundish, and are marked with an embryo a little prominent, at the place where they were fastened in the pericarpium; and when the seeds begin to grow, the cotyledons retain the form of half the seeds.

The receptacles proper to the seeds are very small, short, and thinner towards the base; and where they adhere to the disc, obtuse, oblong, inserted along the upper suture only, but placed on each side alternate, so that the seeds adhere to each of the valves.

Singular qualities of plants in this class.

Twining plunts. *-Phaseolus, dolichos, clitoria, glycine.

Feathered without an odd one.-Orobus, pisum, lathyrus, vicia, ervum, arachis.

* There are many other twining plants dispersed in the several classes (as cus cuta, de.) the spirals of which turn different ways by the twisting of the staks: some according to the motion of the sun, and others contrary to his motion, which singularity is not understood ; and is rery different from those which support themselves by claspers, though both may be called climing plants. See cirrus, under Outlines of a plart. 
Feathered with an odd one.-Biserrula, astragalus, phaca, hedysarum, glycyrrhiza, indigofera, galega, colutea, amorpha, piscidia, mullera.

Three-leaved.-Trifolium, lotus, medicago, erythrina, genista, cytisus, ononis, trigonella, phaseolus, dolichos, clitoria, monnieria.

Umbelled plants.-Lotus, coronilla, ornithopus, hippocrepis, scorpiurus.

This class contains four orders, founded on the number of stamina considered as distinct.

\section{ORDER I. PENTANDRIA.}

(FIVE STAMINA OR MALES.)

No Genera. Growth. Species. Native of $\quad \begin{gathered}\text { Species in } \\ \text { Britain. }\end{gathered}$

1 Monneria h 1 America

ORDER II. HEXANDRIA.

(SIX STAMINA OR MALES.)

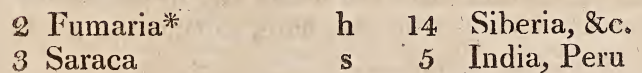

Brit. 3

ORDER III. OCTANDRIA.

(EIGHT STAMINA OR MALES.)

4. Coumaroura

5 Dalbergia

6 Polygalat

1

7 Securidaca

$\begin{array}{rrl} & 1 & \\ \text { s } & 2 & \text { Surinam } \\ \text { h } & 38 & \text { Brasils, Senegal, \&c. Brit. } 1 \\ \text { s } & 2 & \text { Jamaica, Europe }\end{array}$

1.

* Fumaria.-See note to alcali in the Index.

+ Polygala senega (senega rattle-snake root) called so from its being a cure for the bite of a rattle-snake; the root is powdered, and both taken inwardly, and applied to the part bitten. 


\title{
ORDER IV. DECANDRIA.
}

\author{
(TEN STAMINA OR MALES.)
}

\begin{tabular}{|c|c|}
\hline & $N^{\circ}$ of \\
\hline
\end{tabular}

\section{1st. Stamens all connected.}

8 Abrus
9 Amorpha
10 Anthillis
11 Arachis*
12 Aspalathus
13 Borbonia
14 Bossiæa
15 Crotalaria
16 Cylista
17 Ebenus
18 Erythrina $\$$
19 Genista
20 Ivira
21 Lupinus $\$$
22 Moutouchia

$\begin{array}{crll}\text { \& } & 1 & \text { India } & \\ \text { s } & 1 & \text { Carolina } & \\ \text { s \& h } & 15 & \text { Italy, \&c. } & \text { Brit. } 1 \\ \text { h } & 1 & \text { South America } & \\ \text { s } & 35 & \text { Crete, Ethiopia, India } \\ \text { s } & 6 & \text { Cape } & \\ \text { s } & 1 & \text { Botany Bay } & \\ \text { h } & 23 & \text { China, Carolina } & \\ \text { s } & 1 & & \\ \text { s } & 1 & \text { Crete, Cape } & \\ \text { s \& h } & 5 & \text { Carolina } & \text { Brit. } \\ \text { s } & 14 & \text { Spain, \&c. } & \\ \text { h } & 1 & & \\ \text { h } & 7 & \text { Virginia, France } & \\ \text { h } & 1 & & \end{array}$

* Arachis hypogrea (ground nut) receives its trivial name from hiding its seetl in the earth; the branches trail upon the ground, and the flowers (which are yellow, and monæcious) are produced singly upon long foot-stalks, and as the flowers decay, the germen is thrust into the earth, where the pod is formed and ripened.-Similar to this is the cyclamen; when the flowers decay, the footstalks twist themselves spirally downwards to the earth, to lodge the seeds ; which are supposed for some time to receive nourishment from the plant, as they are often difficult to make grow when sowed in the common way.-Linnæus also tells us that the little globular heads of the trifolium sulterranetum penetrate the earth.-The arachis hypogoen is cultivated in Spain and France for its oil : it is said that the seeds of it yield more than half their weight of an oil which is fit to be used in food, to burn in lamps, or employed in the arts; as in making soap, \&c.

+ Crotalaria juncea is the Chinese hemp, very common in India, called sunn, or sunn hemp; is managed in the same manner, and used for the same purposes as the common hemp.

* Coral tree (erythrina) called so from the flowers being collected in long close spikes of a scarlet colour, somewhat resembling coral. -N. B. real coral not perfectly known whether formed by animals, or to be a mineral, or of vegetable production.-Erythrina is also called the American bean tree, from its bearing pods with seeds in them like beans.

$\S$ The seeds of the tupine were used by the Greeks for food; and Mr. Miller says that the white lapine is cultivated in some parts of ltaly, as other pusle for food. 


\begin{tabular}{|c|c|c|c|c|}
\hline Genera. & Growth. & $\begin{array}{l}\text { No of } \\
\text { species. }\end{array}$ & Native of & $\begin{array}{l}\text { Species it } \\
\text { Britain. }\end{array}$ \\
\hline Mullera & $\mathbf{t}$ & 1 & Surinam & \\
\hline Niss & $\mathrm{t}$ & 2 & America & \\
\hline Ononis & $\mathrm{s} \& \mathrm{~h}$ & 31 & Cape, \&c. & Brit. 3 \\
\hline Piscidia* & $\mathfrak{g}$ & 2 & W. Indies & \\
\hline Platylobium & s & 4 & New Holiand & \\
\hline Pterocarpus & $t$ & 5 & W. Indies & \\
\hline Spartiumt & s & 16 & Cape, \&c. & Brit. 1 \\
\hline lea & & 1 & & \\
\hline nnus & & 1 & & \\
\hline Tet & h & 1 & & \\
\hline Ulex & S & 2 & Cape, I & . \\
\hline
\end{tabular}

\section{2d. Stigmas downy, (not amongst the former).}

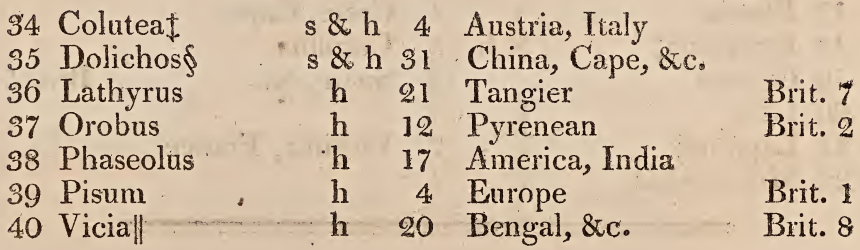

* The bark of the dogwood tree (piscidia erythrina) being pounded and put into a sack, and thrown into any water, and afterwards squeezed, will in a short time intoxicate the fish, so that they may be taken by the hand, without imparting any bad quality to the fish; a diversion much used in the W. Indies.

+ Spartium scoparium (corrmon English broom) is the sort used in medicine; chiefly in dropsical complaints.

† The leaves and seeds of bladder senna (colutea arborescens) being purgative, are often substituted in Italy, \&c. for the senna of the shops; so are also the leaves of scorpion senna (coronilla emerus).

$\S$ Dolichos pruriens (cowage) is said to be famous as an anthelmintic, and hath given occasion to a Practical Treatise on the superior efficacy of stizololium, or cowage, internally given, in diseases occasioned by worms.

By Wm. Chamberlaine.-9th edit. 1805,3 s.

\|I Bush-vetch (vicia sepium) being an indigenous perennial evergreen, is much recommended as a fodder for cattle, and is said to produce above four tons of dry fodder on an acre, but it is not easily raised from seed, being much infested by insects

Bath Society. 
No of

No Genera. Growth. Species. Native of Britain.

3d. Legumen somewhat two-celled, (not of the former).

41 Amerimnon

42 Astragalus*

43 Biserrula

44. Phaca h 1

s \& h 47 Alps, Syr.Canada,\&c. Brit. 3

h 1 Sicily

h 10 Alps, Siberia

4th. Legumen mostly one-sceded, (not of the former).

$\begin{array}{llrl}45 \text { Acouroa } & \text { h } & 1 & \\ 46 \text { Deguelia } & \text { h } & 1 & \\ 47 \text { Glycyrrhiza } & \text { h } & 4 & \text { Apulia, Spain } \\ 48 \text { Parivoa } & \text { h } & 1 & \\ 49 \text { Psoralia } & \text { s } & 23 & \text { Africa, America } \\ 50 \text { Trifolium } & \text { h } & 46 & \text { Italy, \&c. }\end{array}$

Brit. 17

5th. Legumen rather jointed.
51 Eschynomene,
s 8 America, India
52 Coronilla
s \& h 11 Crete, America
53 Hedysarum +
s \& h 67
h 4 Italy
s \& h 10 America
Brit. 1
55 Medicagot
Brit. 4

s

* Gum tragacanth is from a species of asiragalus, called astragalus tragacantha. But in M. Bilardier's memoirs on the tree which furnisheth the gum tragacanth, he says that the astragalus tragacantha of Linnæus, which is found at Marseilles, affords no gum : but that the true gum tragacanth occurs as an exudation from many species of astragalus; though that found on Mount Lebanus, from whence it is chiefly collected, hath not hitherto been described by botanists.

+ The hedysarum gyrans, a shrub mentioned in the Sup. Plan. of the younger Linnæus, is very remarkable for its self-moving power; it is a native of the E. Indies, grows to the hight of about four feet, and in Autumn produces yellow flowers. Its leaves are three'd, those on the sides are smaller than those at the extremity, and in the day, they are continually moving either upward or downwards, or in the segment of a circle; the last motion is performed by the twisting of the footstalk, and whilst one leaf is rising, the opposite is generally descending. A selfmoving power at certain times is also discovered in the stamina of many plants. See note to collinsonia.

¥ The medicago polymorpha hath many varieties, which consist in the shape of the pods; as some resemble snails; others, caterpillars; others, hedge-hogs, \&c. Medicago arborea is the upright moon trefoil, and is supposed by some to be the cytisus of Virgil. Medicago falcata is the prostrate moon trefoil. 


\begin{tabular}{|c|c|c|c|c|}
\hline Geners. & Growth. & $\begin{array}{l}\text { No of } \\
\text { species. }\end{array}$ & Native of & $\begin{array}{c}\text { Species in } \\
\text { Britain. }\end{array}$ \\
\hline 56 Ornithopus & h & 4 & France & Brit. \\
\hline 57 Scorpiurus & h & 4 & Europe & \\
\hline 58 Smithia & h & 1 & E. Indies & \\
\hline 59 Stylosanthes & h & 1 & & \\
\hline
\end{tabular}

6th. Legumen one-celled, muny-seeded, (not of the former).

60 Cicer
61 Clitoria
62 Cytisus
63 Diphysa
64 Ervum
65 Galega
66 Geaffroya*
67 Glycine
68 Indigoferat
69 Liparia
70 Lotus
71 Robinia
72 Trigonella

h 1 Spain

h 5 Virginia, Brasil

t \& s 17 Alps, \&c.

h 1

h 6 France

h 12 Spain, America

Brit. 2

$t 2$ Brasil, Jamaica

$\mathrm{s} \& \mathrm{~h} 15$ America

s \& h 23 E. \& W. Indies

s 5 Cape

h 19 Arabia, Crete

s 9 N. America

h, 11 . France, India

Brit. 1

* Geoffroya had only one species known to Linnæus, which he calls spinosa: but William Wright, M.D. in the Philosophical Transactions for 1777, p. 512, table 10, adds another of the specific name of inermis, and calls it the cabbage-bark tree, and recommends the bark as an anthelmintic.

See London Magazine for 1778, p. 264.

+ The finest indigo is made from the leaves of the indigofera tinctoria, a cosrser sort is made from the leaves and small twigs. 


\title{
CLASS XVIII. POLYADELPHIA.
}

\author{
(MANX BROTHERHOODS.)
}

The flowers of this class have their stamina in three or more sets or bodies, severally united at the base; and gene. rally placed on the receptacle.*.

Containing four orders.

\section{ORDER I. PENTANDRIA.}

(FIVE STAMINA OR MAIES IN EACH SET.)

\begin{tabular}{|c|c|c|c|}
\hline Genera. & Growth. $\begin{array}{c}\text { No of } \\
\text { species. }\end{array}$ & Native of & $\begin{array}{l}\text { Species in } \\
\text { Britain. }\end{array}$ \\
\hline 1 Ambroma & h & & \\
\hline 2 Theobromat & 2 & W. Indies & \\
\hline
\end{tabular}

\section{ORDER II. DODECANDRIA.}

(FROM TWELVE TO TWENTY MALES IN SEVERAL SETS.)

3 Monsonia
s 3 Cape.

ORDER III. ICOSANDRIA.

(TWENTY MALES IN SEVERAL SETS.)
4. Citrus $\ddagger$
t 4. Asia, Japan, \&c.

* See note to aizoon, where the stamina are inserted by sets into the calyx.

+Theobroma cacao, though called chocolate nut, is not properly a nut, but, according to Linnzeus, hath an oblong woody pod or pericarpium, containing many fleshy seeds, of which chocolate is made; and what is called cocoa in the shops, is made of the shells, husks, and refuse of the chocolate.

$¥$ Bergamot is a fragrant essence obtained from a cyon of the limon (citrus me. dica) grafted on the stock of a bergamot; whence the name. Citrus medica (ths citron) contains also several varieties, as lime, limon, \&c. 


\section{ORDER IV, POLYANDRIA. (MANY MALES IN SEVERAL SETS.)}

Wo Genera. G Growth. species. Native of
Calyx one leaf.

5 Ocatea

h 1

Calyx two-leaved, beneath.

6. Ascyrum

s \& h 3 Virginia

Calyx five-cleft, above.

7 Hopea

8 Melaleuca s 1 Carolina

s 8 New Zealand, New Holland

Calyx five-cleft, beneath.

9. Durio

10 Glabraria

11 Hypericum*

12 Symplocost t 1 E. Indies

s 1 E. Indies

s \& h 42 America, Egypt, \&c. Brit. 8 1 Martinico

Calyx six-cleft, beneath.

* Hypexicum varies as to number of styles, there are generally three, sometimes five, some have only two, and one species hath only one, which is a distinction of the species.

+ M. L. Heritier pronounces the four genera symplocos, hopea, alstonia, and ciponima, to be in reality but one, to which he gives the name of symplocos, and describes six species. 


\section{CLASS XIX. SYNGENESIA.*}

\section{(CONFEDERATE MALES.)}

This class consists 'of compound aggregate flowers, which (as before explained under the head of distinction of flozeers) are such flowers as are formed by the union of several lesser flowers or florets, placed sitting (or without peduncles) on a common dilated receptacle, and within a common calyx, called a perianthium; each floret consisting of a single petal, with generally five divisions, and having five stamina distinct at the base, but united at the top by the antheræ into a cylinder, through which passeth the style of the pistillum, longer than the stamina, and crowned by a stigma with two divisions that are rolled backwards; and having a single seed placed upon the receptacle under each floret.-This is the general character of a regular compound flower, to which there are a few exceptions in the order monogamia; but the essential character consists in the anthere being united so as to form a cylinder, and having a single seed placed upon the receptacle under each floret: yet this is not without some exceptions in the order monogamia.

Lirnaus also gives a further character of a flower in its regular compound state, which he calls a flosculous flower, (taken from the calyx and receptacle, the only parts that are in common, and by which antient botanists founded their

* The name of this class means congeneration, alluding to the circumstance of all the stamina being united by their antheræ, and therefore is translated confes derate males.

Some flcwers have such close heads, as at first sight appear to be of the class syngenesia, but if they want the essential character of a compound flower, they belong to some other class.-The florets in a compound flower have generally a small calyx, which is always a perianthium, and remains, so as to become the crown of the seed.

This class differs from the adelphia classes, in the stamina not being joined at the bottom by the filaments, but at the top by the antheræ.

This class is natural, except the last order monogamia, which upon systematic principles was found necessary to be admitted, as having the antheræ united.

The plants have various specific virtues, though most of them are bitter and stomachic. None of them are poisonous, except perhaps lactuca virosa (strong scented lettuce), especia!ly in shady situarions; and doronicum (leopard's bane), and carthamus (base safiron or safflower). 
distinction), and also of a floret or floscule; he also calls the coinpound Hower flos universalis, and the florets of which it is composed, he calls flores proprii.

\section{Charaiter in the compound state.}

Caryx. A common perianthium containing the receptacle and florets; which contracts when the florets are fallen, but expands and turns back when tle seeds are ripe. It is either simple, as when composed of only a single row of scales or leaves; imbricated, (tiled) as when the scales are numerous, and the outer lie upon the inner, like tiles upon a house; or augmented, (increased or leafy) as when a single row of longer leaves or segments of the calyx surrounds the florets, and another row of very small leaves or scales surrounds the base of those longer leaves or segments.

RECEPTACLE. Is the common receptacle of the fruetification, receiving many florets sitting on its dise; which is either concave, convex, flat, pyramidal, or globular; and the surface of the disc is either nalked, withont other inequality than that of being lightly dotted, as in leon todon, \&c.; hairy, covered with upright hairs, as in carduus, \&c.; or chaffy, covered with linear, awl-shaped, compressed, upright paleæ or chaffy substances, sepa* rating the florets, as in anthemis, achillea, \&c.

\section{Character of a floret.*}

CALYx. When present, a small perianthium with generally five clefts, sitting upon the top of the germen, and afterwards becoming the crown of the seed.

Corozia. One petal, tube very narrow, long, seated on the germen, with generally three or five clefts or teeth: And is either tubular, with the border funnelled or bell-shaped, five-cleft, the segments reflexed and expanding; or ligulate (from ligula, a strap or fillet), having a short tube with border linear, flat, turned outward, and the top entire,

* 'The character here given is of a monoclinian fioret. 
with three or five teeth, lopped. In some genera, the corolla in some of the species is wanting, as in artemisia and gnaphalium.

Stamina. Filaments five, capillary, very short, inserted in the neck of the corollula. The antheræ five, erect, linear, joined at the sides so as to form a hollow cylinder with five teeth, and as long as the border of the floret.

Pistillum. Germen oblong, placed under the floret, upon the common receptacle. The style thread-shaped, erect, as long as the stamina, passing through the cylinder formed by the antheræ. The stigma two parts, the parts rolled back, and expanding.

Pericarpium. Properly none, though in some genera there is a coreaceous or leathery crust over the seed, as in osteospermum and strumpfia.

Semina. Single, oblong, often with four edges, generally narrower at the base, and are crowned either with a feather (pappus), or with the perianthium, or hath no crown; if with a feather, it is either sitting, or placed on footstalks (stipes), consisting of many radii placed in a circle, which are either simple, radiate, or branching; if with a perianthium, it is small, permanent, with generally five teeth.

Oвs. Compound flowers are of the following sorts :

1. Tubular monoclinian florets both in the disc and ray.

2. Tubular monoclinians in the disc; tubular females in the ray.

3. Tubular monoclinians in the disc; tubular neutrais in the ray.

4. Tubular monoclinians in the disc; ligulated monoclinians in the ray.

5. Tubular monoclinians in the disc; ligulated females in the ray.

Ors. The disposition of the sexes varying, occasions the following distinctions: It is called a tubular monoclinian floret, if stamina and pistillum are both present; a tulular masculine floret, if furnished with stamina but no pistillum or stigma; a tubular femenine floret, if a pistillum without stamina; and a tubular neuter floret, if neither stamina nor pistillum. If the corolla of the floret is ligulate, then it is called a ligulate floret, and either monoclinian, masculine, feminine, or neuter, according to the foregoing distinctions.-Besides the above description, compound flowers, from the difference of their structure, admit of further divisions, which gives rise to the orders.

When all the florets are tulular, that is, consist of hollow, tubular, funnel-shaped petals, they are called flosculi, and the whole flower is called flos flosculus. This term seems opposed to radiate flowers, where the flowers of the radius differ in form from those of the disc. See the note to centaurea. 
This clasis contains six orders.

\section{ORDER I. POLYGAMIA EQUALIS.}

\section{(EQUAL POLYGAMY.)}

It is called equal because all the florets are monoclinian, and none of them radiate (except atractylis).

No Genera. Growth. Species, Native of $\begin{gathered}\text { No of } \\ \text { Britain. }\end{gathered}$

1st. Semiflosculous* flowers of Tournefort with all the corols ligulated.

Receptacle chaffy.

$\begin{array}{lllll}1 \text { Catananche } & \text { h } & \text { 3 } & \text { Crete, Greece } & \\ 2 \text { Cichorium } & \text { h } & 3 \text { Europe } & \text { Brit. } 1 \\ 3 \text { Geropogon } & \text { h } & 3 \text { Italy } & \text { Brit. } 3 \\ 4 \text { Hypochæris } & \text { h } & 4 \text { Europe } & \\ 5 \text { Scolymus } & \text { h } & 2 \text {. Spain, Italy } & \\ 6 \text { Seriola } & \text { h } & 4 \text { Crete, Italy, Etna } & \end{array}$

Receptacle villous or hairy.

\section{Andryola}

\section{Receptacle naked.}

$\begin{array}{llrll}\text { 8 Chondrilla } & \text { h } & 3 \text { Germany } & \\ 9 \text { Crepis } & \text { h } & 16 & \text { Alps, Siberia } & \text { Brit. } 8 \\ 10 \text { Hieracium } & \text { h } & 35 & \text { Alps, Cape } & \text { Brit. } 9 \\ 11 \text { Hyoseris } & \text { h } & 9 & \text { Virginia } & \text { Brit. 1 } \\ 12 \text { Kleinia } & \text { h } & 1 & & \\ \text { 13 Lactucat } & \text { h } & 10 & \text { India, Canada } & \text { Brit. 3 }\end{array}$

* Semiflosculous flowers of Tournefort, means such florets as are flat above, and zubular or hollow below, as dandelion, goat's-leard, hawkweed, \&c. and correspond 'with the ligulati of Linnæus; the lingulati of Pontedera; the planipetali of Boerhave and Ray ; the cichoracei and acanacce of Cæsalpinus; and the lactescentes of Morison.

+ Lactuca sativa (garden lettuce) as observed by Dr. Carradorri, shews great sensitive irritability at certain periods of its growth, for when it is in flower or in seed, if it be gently touched with the finger, a blade of grass, or any pointed body, it will emit a milky liquor, in the form of very minute drops; but this phenomenon. is said to occur only in the small amplexicaul leaves of the branches, or the leaflets of the calyx. 
No of

No Genera. Growth. species. Native of

Species in Britain.

14 Lapsana

15 Leontodon*

16 Picris

17 Prenanthes

18 Scorzonera

19 Sonchust

20 Tragopogon

$\begin{array}{lrll}\text { h } & 5 & \text { Portugal } & \text { Brit. 1 } \\ \text { h } & 10 & \text { Europe } & \text { Brit. 4 } \\ \text { h } & 4 & \text { Italy, France } & \text { Brit. 2 } \\ \text { h } & 19 & \text { Japan, \&c. } & \text { Brit. 1 } \\ \text { h } & 14 & \text { Spain, \&c. } & \\ \text { \& h } & 13 & \text { Alps, Siberia } & \text { Brit. 4 } \\ \text { h } & 14 & \text { Virginia, E. Indies } & \text { Brit. 2 }\end{array}$

2d. Headed flowers,

That is, connected on the summit of the footstalk into a knob or head.

\begin{tabular}{|c|c|c|c|c|}
\hline 21 Arctium & $\mathrm{h}$ & 3 & Europe & Brit. 1 \\
\hline 22 Atractylis & $\mathrm{h}$ & 8 & Italy, Mexico & \\
\hline 23 Barnadesia & $\mathrm{s}$ & 1 & America & \\
\hline 24 Carduus : & h & 38 & Syria, Virginia & Brit. 1] \\
\hline 25 Carlina & h & 8 & Pyrenean & Brit. 1 \\
\hline 26 Carthamus & s \& h & 10 & Crete, Egypt & \\
\hline 27 Cnicusई & h & 9 & Europe, Spain & \\
\hline 28 Cynarail & h & 4 & Italy & \\
\hline 29 Onopordon & h & 5 & Arabia & $\mathrm{Br}$ \\
\hline O Serratula & $\mathrm{h}$ & 15 & Alps, \&c. & Brit. 3 \\
\hline
\end{tabular}

* Leontodon taraxacum (dandelion, or lion's tooth) is said to be good in com. plaints of the liver, and promotes urine. It is sometimes called wild cichory, or endive. The young leaves are eaten by the French as a salad; and the root dried and pounded is said to be used by the French as a substitute for coffee, to which it assimilates both in scent and flavour.

TThe common sow-thistle (sonchus oleraceus) is described as having downy peduncles, and smooth calyxes:-And there is another sort very similar in external appearance, that have downy peduncles, and hairy calyxes; but Dr. Murray says this latter is a distinct species, which he calls sonchus tenerrimus.

$\ddagger$ The stems of the arctium lappa (burdock) stripped of the skin (before the flowers appear) and boiled, are eaten as asparagus; and are even eaten raw with oil and vinegar. And most of the thistle kind (carduus) may be used in the same way.

§ Cnicus acarna seems, by Linnæus, to be intended for the carduus benedictus, or blessed thistle, and Mir. Miller is of the same opinion; it also appears so on examination; but in the Pharmacopreia Edinburgensis, printed in 1783 , it is said to be centaurea benedicta; and $\mathrm{Mr}$. Aiton, in his Hortus Kewensis, printed in 1789, makes it the same.

II The esculent part of the cynara scolymus (common artichoke) is the receptacle, and the fleshy part of the leaves of the calyx; as in onopordon acanthium the receptacle and young stems are eat as artichokes. 
No Genera. Growth. $\begin{gathered}\text { No of } \\ \text { species. Native of } \quad \begin{array}{c}\text { Species in } \\ \text { Britain. }\end{array}\end{gathered}$

3d. Disc-like flowers,

That is, placed on a surface like a disc; as the disc of the sun, moon, \&c.

Receptacle naked.

31 Adenostemma

32 Ageratum

33 Cacalia

34. Chrysocoma

35 Ethulia

36 Eupatorium

37 Spilanthus*

h $\quad 1$

h 2 America

s \& h 27 Alps, Africa

s \& h 13 France, Africa

h 5 India

h 29 Ceylon, Brazils, \&c. Brit. 1

h 7 Ceylon

Receptacle chaffy.

38 Athanasia

s 20 Cape, \&c.

h 12 America

39 Bidens

40 Calea

41 Santolina

42 Stæhelina

h 4 Jamaica

Brit. 1

s 4. Spain, Alps

s 8 Africa

Receptacle hairy or bristly.

43 Pteronia

44. Tarconanthus

s 17 Ethiopia

s 3 Cape

\section{ORDER II. 'POLYGAMIA SUPERFLUA. \\ (SUPERFLUOUS POLYGAMY.)}

Having the fiorets of the disc monoclinian, and those of the radius or circumference female, which are considered as superfluous.

1st. Disc-like flowers.

Receptacle naked.

45 Artemisiat s \& h 29 Ethiopia, China Brit. 5

* The spilanthus acmella is very famous in the island of Ceylon for curing the stone and nephritic complaints; the leaves dried, and the seeds, are said to be most effectual, used by infusion; but the root, stalk, and branches are also used.

Universal Magazine for June, 1752, p. 251.

t The moxa, so famous in the East for curing the gout, by cauterizing the part affected, is the lanugo or down of the leaves of a species of Indian mugwort (artemisia chinensis). - See note to alcali, in the Index. Artemisia absinthium (common 
No of

Speries in

No Genera. Growth. species. Native of Britain.

46 Baccharis

s 8 America, Africa

47 Carpesium

h 2 Italy, China

48 Conyza

49 Gotula

s \& h 25 China, \&c.

h 13 Spain, \&c.

Brit. 1

50 Gnaphalium

s \& h 59 Alps, India

Brit. 6

51 Tanacetum

$\mathrm{s} \& \mathrm{~h} 7$ Siberia, Africa

Brit. I

Receptacle chaffy.

52 Anacyclus

h 4 Crete

53 Xeranthemum s \& h 16 Austria, \&c.

2d. Semiflosculous flowers, rather two-lipped.

Receptacle naked.

54. Perdicium

h. 5 Alps, Magellan

3d. Radiate flowers.*

Receptacle naked.

55 Arnica

56 Astert

57 Bellis

58 Bellium

59 Cineraria

60. Chrysanthemum

61 Doronicum

62 Erigeron

63 Helenium h 11 Africa, Japan

s \& h 38 Siberia, China

h 2 Spain

h 2 India

s \& h 26 Siberia, Cape

s \& h 24. Alps, India, \&c.

h 3 Alps

h 22 Alps, America

h 1 America
Brit. 1 Brit. 1

Brit. 2 Brit. 3 Brit. 1 Brit. 2

wormwood) is used by the common people in Wales instead of hops, and will destroy acescency in beer when grown hard. It is said the leaves steeped in boiling water, and repeatedly applied to a recent bruise, remove the pain, and prevent swelling and discoloration of the part. Artemisia annua (a species of mugwort) in decoction, is the base of all the colours which are given to the Turkey leather. To dye red, cochineal, in powder, is mixed with the decoction; and alum is added, to fix the colour.

* See radiate flowers described in a note under the head of distinction of flowers.

+ The asters are a very numerous family; Linnæus makes thirty-eight relatives, under different distinctions; Aiton enumerates forty-two; and Donn, who hath the care of the botanic garden at Cambridge, mentions sixty. 


אN Generà
64 Inula*
65 Matricaria
66 Mutisia
67 Pectis
68 Senecio
69 Solidago
70 Tagetes
71 Tussilago
72 Unxia

73 Achilleat

74 Amellus

75 Anthemis

76 Buphthalıum

77 Eclipta

78 Leycera

79 Sigesbeckia

80 Tridax

81 Verbesina

82 Zinnia

\begin{tabular}{|c|c|c|c|}
\hline Growth. & $\begin{array}{l}N^{\circ} \text { of } \\
\text { specis. }\end{array}$ & Native of & $\begin{array}{l}\text { Species in } \\
\text { Britain. }\end{array}$ \\
\hline h & 29 & Arabia, Germany & Brit. 4 \\
\hline h & 6 & Europe & Brit. 4 \\
\hline h & 1 & New Granada & \\
\hline h & 3 & Ameriça & \\
\hline $\mathrm{s} \& \mathrm{~h}$ & 59 & Egypt, Siberia & Brit. 8 \\
\hline $\mathrm{h}$ & 14 & Canada, Mexico & Brit. 2 \\
\hline h & 3 & Mexico & \\
\hline h & 12 & Alps, Japan & Brit. 3 \\
\hline h & 1 & Surinam & \\
\hline
\end{tabular}

h 21 Egypt, Alps, Crete Brit. 2 $\mathrm{s} \& \mathrm{~h} 2$ Cape

s \& h 18 Alps, America Brit. 5

$\mathrm{s} \& \mathrm{~h} 11$ America, \&c.

h 4 Virginia

s 3 Fthiopia

h 2 China, $W$. Indies

h 1 Vera-Crux

s \& h 11 China, Virginia

h 2 Peru

\section{ORDER III. POLYGAMIA FRUSTRANEA.}

\section{(FRUSTRANEOUS POLYGAMY.)}

Having the florets of the disc monoclinian, and those of the radius neuter + ; hence called frustraneous. All radiate.
83 Graillardiaई
s 1 Loụsiana

* In inula the two bristles fixed to the lower part of each lip, is the essential character.

+ Achillea ageratum (sweet maudlin) is a culinary berb, used in stuffing flesh meat, which gives it a pleasant flarour; the flower is yellow.-Of late it became very scarce, and the achillea alpina was substituted in its stead, and sold for sweet zoudlin, but hath a different flavour, and probably different qualities, and the fower is white. Miller's Dictionary.

$\mp$ The florets in the radius are described as female in the Gert. Plunt.; but some part being defective, and consequently barren, they are called neuter.

§ Gaillardia (from M. Gaillard) pulchella, is a new genus mentioned by M. Troujeroux in the French academy of sciences for 3786 , it flowers from the midale of July to the end of October, and if it can be made double by cultivation, will supersede the China-aster; it appears by the plate to be a beautiful shrubby plant, with numerous flowers. 
SX NGENESTA.

No Genera. Growth. species. Native of $\quad \begin{gathered}\text { No of } \\ \text { Britain, }\end{gathered}$

Receptacle rather naked.

84 Gorteria
85 Sclerocarpus

86 Centaurea*

87 Zægæa s $\&$ h 12 Africa

1 Africa.

Receptacle bristly.

Receptacle chaffy.

$\begin{array}{lcrl}88 \text { Coreopsis } & \text { h } & 12 & \text { Virginia, \&c. } \\ 89 \text { Helianthus } & \text { h } & 13 & \text { India, America } \\ 90 \text { Osmites } & \text { s } & 4 & \text { Cape } \\ 91 \text { Rudbeckia } & \text { h } & 6 & \text { Canada, Carolina }\end{array}$

ORDER IV. POLYGAMIA NECESSARIA.

(NECESSARY POLYGAMY.)

Having the florets of the disc male, and those of the radius female;

hence called necessary.

Receptacle naktd.

92 Baltimora
93 Calendula
94 Filago
95 Hippia
96 Micropus
97 Milleria
98 Osteospermum
99 Othonna

h 1 Maryland

s \& h 9 France, \&c.

h 7 France, Germany Brit. 3

s \& h 3 America

h 2 Spain

h 2 Panama

h 15 Africa, America

s $\&$ h 26 Africa, France 


No Geneta. Growth. species. Native of
Receptacle hairy.

100 Arctotis

101 Eriocephalus s \& h 12 Ethiopia; \&c.

s 2 Africa

Receptacle chaffy.

$\begin{array}{llll}102 \text { Chrysogonum } & \text { h } & 1 & \text { Virginia } \\ 103 \text { Melampodium* } & \text { h } & 2 & \text { America, Vera-Crux } \\ 104 \text { Polymnia } & \text { h } & 7 & \text { Canada, Abyssinia } \\ 105 \text { Silphium } & \text { h } & 8 & \text { America }\end{array}$

\section{ORDER V. POLYGAMIA SEGREGATA.}

(SEPARATE POLYGAMY.)

Such flowers as have many partial or lesser calyxes containing one or more florets, and placed within a common calyx; by which the florets are separated.

One floret.

106 Echinops

107 Stcebe

h 4 Italy

h 9 Africa

Three florets.

108 Jungia

1 America

Four florets.

109 Elephantopus h 2 E. \& W. Indies

Five florets.

110 Gundelia

h 1 America

Fight florets.

* Melampodiam was the name given by Pliny to black helebore, which, accord * to the Edinb. Dispens., is now helleborus niger. 


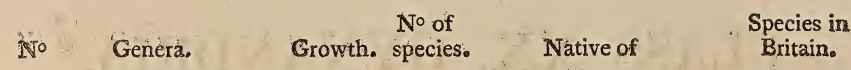

\section{Many florets.}

$\begin{array}{llll}112 \text { OEdera } & \text { s } & 2 & \text { Cape } \\ 113 \text { Craspedia } & \text { h } & 1\end{array}$

\section{ORDER VI. MONOGAMIA.}

(MONOGAMY.)

Containing simple flowers with the antheræ united.

$\begin{array}{lrrll}\text { 114 Corymbium } & \text { h } & \text { 4 } & \text { Ethiopia } & \\ 115 \text { Jasione } & \text { h } & \text { 1 } & \text { Europe } & \text { Brit. 1 } \\ 116 \text { Impatiens* } & \text { h } & \text { China } & \text { Brit. 1 } \\ 117 \text { Lobelia } & \text { h } & 42 & \text { Ceylon, \&c. } & \text { Brit. . } \\ 118 \text { Seriphium } & \text { s } & 4 & \text { Ethiopia } & \\ 119 \text { Shawia } & & 1 & & \\ 120 \text { Strumpfia } & \text { s } & 1 & \text { America } & \\ \text { 121 Violat } & \text { s \& h } 29 & \text { America, \&c. } & \text { Brit. } 6\end{array}$

* Impatiens noli tangere (touch me not) receives its name from its taper pods, when ripe, bursting on being touched; and twisting spirally like a screw, leap from the stalk, and cast out the seeds with great elasticity.-Miller's Dict. See note to momordica.

$\uparrow$ In Europe the flower of the common violet always hangs down, in the Indies it is generally upright. In the Synopsis of British Plants, published in Latin by J. Symons, in 1798, the genus viola is removed to the class pentandria.-And Dr. Smith dismisses the whole of this order monogamia, and places it in the class pentandria, because the union of the anthers is not constant.

Panorama for Sept. 180 . 


\section{CLASS XX. GYNANDRIÁ.*}

(FEMININE MALES.)

The flowers of this class are distinguished by having the stamina placed upon the style, or rather, upon a columnar receptacle lengthened out into the form of a style, supporting: both the stamina and pistillum.

In examining and comparing the characters of this class, it is more necessary to attend to the pistillum before the stamina, in order to attain a distinct idea of the latter.

All the flowers of this class have a very singular appearance, owing to the uncommon disposition of the sexes.

The first order (diandria) of this class is natural, and its genera (formerly distinguished by the root) Linnæus distinguisheth by the nectarium alone.

The flowers also of this order are very singular, having the following description:

CALxx. A spatha protruding a spadix, and the flowers have no perianthium.

Coroula. Five petals, of which the two inner generally approach so as to form an helmet, the outer are larger, and nearly equal; the lower lip of the helmet constitutes a nectarium, and hath the appearance of a sixth petal; and the upper lip is incorporated with the style of the pistillum.

Sramina. Always two, the filaments very short, supporting two antheræ, narrower downwards, naked, and divisible: The antheræ are generally enclosed by little cells, open underneath, and covered by , a fold of the uppex lip of the nectarium.

* The name of this class means woman-man, in allusion to the singular circurm. stance of the stamina growing upon the pistillum; so that the male and female are
united, and do not stand separate as in other flowers; and is therefore translatee: feminine males; and is the only class in which the flowers ought, with any pros priety, to bear the name of hermaphrodites. 
Pistillum. Germen always below the corolla, oblong, and twisted like a screw. Style single, very short, forming one substance with the inner margin of the upper lip of the nectaritum, so as both style and stigma are scarce to be perceived.

Pericarpium. A capsule, one cell, three valves, opening at the angles under the keel-shaped sutures, and joined both at top and bottom.

Semina. Very small, like saw-dust, very numerous, fixed (without footstalks) to a linear receptacle, at each valve.

This class contains nine orders.

\section{ORDER I. DIANDRIA.*}

(TWO MALES.)

OBs. It is observed, that though the stamina in this first order are only considered as two, yet each of them appears to be composed of a great number of elastic fibres united together, each fibre supporting its own proper anthera; these fibres branch out into lesser, each supporting at its point an extreme minute anthera.

\begin{tabular}{|c|c|c|c|c|}
\hline Genera. & Growth. & $\begin{array}{l}\text { No of } \\
\text { species. }\end{array}$ & Native of & $\begin{array}{c}\text { Species in } \\
\text { Britain. }\end{array}$ \\
\hline 1 Arethusa & h & 7 & Virginia, Cape & \\
\hline 2 Cypripedium & h & 3 & Lapland, Japan & Brit. 1 \\
\hline 3 Disa & $\mathrm{h}$ & 4 & Cape & \\
\hline Epidendrum $†$ & $\mathrm{~s}$ & 32 & E. \& W. Indies & \\
\hline Forstera & h & 1 & New Zealand & \\
\hline Gunnera & $\mathrm{s}$ & 1 & Cape & \\
\hline Limodorum & h & 3 & Jamaica & \\
\hline Ophrys & $\mathrm{h}$ & 28 & Alps & rit. 13 \\
\hline
\end{tabular}

* The plants of this order are possessed of restorative qualities, which chiefly belong to the roots: they are acrid when fresh, but lose that quality when dry, or by warm water.

+The venelloes, which is an ingredient in chocolate, is the pod of the epiden drum vanilla. Most of the species are parasitical. 


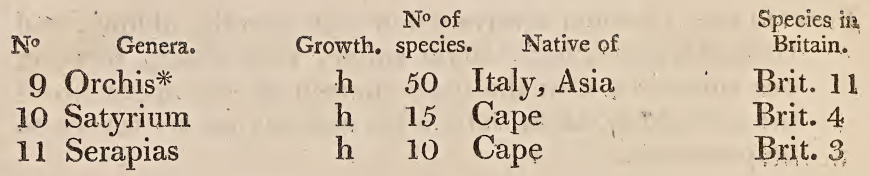

\title{
ORDER II. TRIANDRIA.
}

\author{
(THREE MALES.)
}

\section{One-female.}

$\begin{array}{lrrl}\text { 12 Ferrariat } & \text { h } & 2 & \text { Cape } \\ \text { 13 Salacia } & \text { s } & 1 & \text { China } \\ \text { 14 Sisyrinchium } & \text { h } & 2 & \text { Bermuda } \\ \text { 15 Stilago } & \text { s } & 1 & \text { India }\end{array}$

ORDER III. TETRANDRLA_。 (FOUR MALES.)

One-female.

16 Nepenthes

h 1 Ceylon

ORDER IV. PENTANDRIA.

(FIVE MALES.)

One-female.

17 Ayenia

18 Gluta

h 3 Jamaica

s 1 Java

* The flowers of the different species of orchis and ophrys are very various; oft: resembling different kinds of animals and insects, which have given British names; to many of the species, according to their several representations.-Salep is prepared from the orchis; the bulbs of the orchis mascula are chiefly used, but some. of the palmated bulbs are said to answer equally as well, especially the orchis latifolia; they may be thus prepared,-first to be washed clean, then dipped in hot water in order to separate the brown skin that covers them, which may be rubbed off by a brush or coarse cloth; they are then to be spread on a tin plate, and placed in an hot oven from six to ten minutes, in which time they will lose their whiteness, and acquire a transparency; afterwards are to be dried in the air for use, which will require several days; or may be dried with a gentle heat in a few hours. The time for gathering is when the stalk is ready to fall, for then the new bulb (of which salep is made) is arrived at maturity. In the Synopsis of British plants, published in Latin by J.Symons, 1798, the genus orchis is removed to the class diandria.

+ Ferraria only vegetates every second or third year, though the root remains firm in the ground. 


$$
\text { Three-female. }
$$

19 Passiflora*
\$ 28 Brasils, \&c.

\section{ORDER V. HEXANDRIA. \\ (SIX MALES.) \\ Six-female.}

90 Aristolochia

21 Pistia s \& h 21 France, India

One-female.

\section{ORDER VI. OCTANDRIA.}

\section{(EIGHT MALES.)}

22 Scopolia

$$
\text { ^ } 1 \text { Java }
$$

\section{ORDER VII. DECANDRIA.}

(TEN MALES.)

1

23 Helicterest

24. Kleinhovia
One-female.

s 6 Jamaica, Carthagena

$\mathrm{t} 1$ E. Indies

* The fruit of the passion flower is not yet discovered to be of any use, except the passiflora laurifolia (called water lemon), which Mr. Miller says is commonly used in fever, \&c. as a cooler.-The passiflora carulea, from Brazil, is the hardiest, and grows the highest of any of them, in which the germen, when the flower decays, swells to a large oval fruit, the size of a moderate plum. - The plants are all climbers, and the flowers in general continue but one day.

+ Helicteris (screw-tree) called so because the capsules are twisted together like a screw. 


\title{
ORDER VIII. DODECANDRIA.
}

\author{
(TWELVE MALES.)
}

No Genera. Growth. species. Native of $\quad \begin{gathered}\text { No of } \\ \text { Britain. }\end{gathered}$

One-female.

25 Cytinus

1 Spain

\section{ORDER IX. POLYANDRIA.}

\author{
(MANY MALES.)
}

One-female.

26 Grewia

27 Xylopia

$\begin{array}{lll}\$ & 6 & \text { Asia, Cape } \\ \text { s } & 2 & \text { America }\end{array}$

Spathe.

28 Ambrosinia

29 Arum*

30 Calla

31 Dracontium

32. Pothos

33 Zostera†

$\begin{array}{rrll}\text { s } & 1 & \text { Palermo in Turkey } \\ \text { h } & 26 & \text { Virginia, \&c. } & \text { Brit, } 1 \\ \text { h } & 2 & \text { Fthiopia } & \\ \text { s } & 5 & \text { W. Indies } & \\ \text { s } & 7 & \text { America }\end{array}$

Leaf.

h 2 Holland

* Arum muscivorum (fly-eater). The flower stinks like carrion, by which the fies are allured to lay their eggs, but are prevented from escaping by hairs pointing inwards, and thus perish in the flower; from whence the name. -Sup. Plant. See nate to stapelia.-See wake robin (arum maculatum) in Index of British names.

$\uparrow$ The \&ostera marina (grass-wrack) is very plentiful in the Zuyder Zee in Holland, and is of great use in constructing their banks: when the lighters are laden with it, the fumes which arise will affect the watermen with violent pain in tho eyes, and even with temporary blindness. 


\section{CLASS XXI. MONCECIA.}

(ONE HOUSE.)

This class consists of diclinian (two bed) plants, (viz.) of such genera as have male and female flowerts distinct and separate from each other, on the same plant, which Linnæus also calls androgynous* plants.

But it is to be observed, that florets contained withir a common calyx, though agreeing in this disposition of the sexes, do not belong to this class; which caution is necessary to exclude several species of genera of the umbellate and coms pound flowers, which are sometimes androgynous, but have united antheræ. There are also a few other plan'ts dispersed in the several classes, which properly belong to this class, but as they are only species agreeing with the generic character under which they are placed, they are suffered to remain; as callitriche verna, plantago uniflora, rumex spinosus, glycine monoica, arum triphyllum, mercurialis ambigia.

This class contains eleven orders,

Founded on the number, union, and situation of the stamina in the male flowers:

\section{ORDER I. MONANDRIA.}

\section{(ONE MALE.)}

\begin{tabular}{|c|c|c|c|c|}
\hline Genera. & Growth. & $\begin{array}{l}\text { No of } \\
\text { species. }\end{array}$ & Native of & $\begin{array}{c}\text { Species in } \\
\text { Britaik. }\end{array}$ \\
\hline 1 Balanop & & 1 & & \\
\hline Ceratocarpus & h & 1 & Tartary & \\
\hline Chara & $\mathrm{h}$ & 4 & Europe & Brit. 4 \\
\hline Elaterium & $\mathrm{h}$ & 2 & Carthagena & \\
\hline
\end{tabular}

* See androgynous under Distinction of flowers. 


\begin{tabular}{|c|c|c|c|c|}
\hline Genera. & Growth. & $\begin{array}{l}\text { No of } \\
\text { pecies. }\end{array}$ & Native of & $\begin{array}{l}\text { Species it } \\
\text { Britain. }\end{array}$ \\
\hline 5 Myristica* & $t$ & 2 & W. Indies & 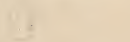 \\
\hline 6 Phyllachne & h & 1 & Terra del Fuego & \\
\hline 7 Zannichellia & h & 1 & Dantzic & Brit. 1 \\
\hline \multicolumn{5}{|c|}{ Amentum. } \\
\hline Egoprigon & $\mathrm{t}$ & 1 & Surinam & \\
\hline Artocarpust & $\mathrm{t}$ & 2 & Batavia, Otaheite & Ceylon \\
\hline Casuarina & $s$ & 2 & India & \\
\hline Cynomorium $\ddagger$ & h & 1 & Jamaica, Malta & \\
\hline Radermachia & $\mathrm{t}$ & 1 & & \\
\hline
\end{tabular}

\title{
ORDER II DIANDRIA.
}

\author{
(TWO MALES.)
}

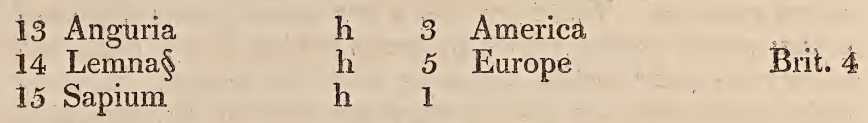

\section{ORDER III. TRIANDRIA.}

\author{
(THREE MALES.)
}
16 Axyris
17 Glochidion
s \& h 4 Tartary, Siberia
h 1

* Myristica (nutmeg) was heretofore placed in the class and order polyandria, monogynia, but it is now found with certainty to belong to this class and order. The spice called mace is the second coat or covering of the nutmeg, next to the shell. There are two sorts of nutmegs sold in the shops by the name of male and female; the fomale is in common use, and in shape of an olive, either roundish or oval; the male is long and cylindric, and has less of the aromatic flavour, and is more subject to be worm-eaten, and which the Dutch call the wild nutmeg.

+ Artocarpus incisa (the bread fruit). The fruit of this tree is used while it is green, in which state it is roasted till the outside becomes scorched and black : the outer part is then rasped off, and the inner part, which is soft and white, like the crumb of new bread, is used for food. It is very wholesome and nutritious, but in taste comes nearer to a sweet potatoe, or Jerusalem artichoke, than to wheaten bread.

$\mp$ In the cynomorium coccineum (the Maltese fungus) the whole plant is an amentum.

$\S$ Lemna minor is called duck's meat, from ducks being fond of it; and it is said the gold fishes from China are very fond of it. 
$\mathrm{N}^{\circ}$ of

Species in

ivo Genera: Growth. Species.

Native of

Britain.

18 Hernandia

19 Omphalia

20 Phyllanthus*

21 Sparganium

22 Tragia

23 Typha

$\begin{array}{ccl}\text { s } & 2 & \text { India } \\ \text { s } & 2 & \text { Jamaica } \\ \text { s \& h } & 7 & \text { Jamaica, India } \\ \text { h } & 2 & \text { Europe } \\ \text { s. \& h } & 6 & \text { India, Virginia } \\ \text { h } & 2 & \text { Europe }\end{array}$

\section{Gluma.}

24. Coixt

25 Olyra

26 Scleria

27 Tripsacum

28 Zeaß

$\begin{array}{lll}\text { h } & 1 & \text { India } \\ \text { h } & 1 & \text { Jamaica } \\ \text { h } & 1 & \\ \text { h } & 2 & \text { America } \\ \text { h } & 1 & \text { America }\end{array}$

Amentum.

29 Carexll

h 45 India, Lapland

Brit. 38

\section{ORDER IV. TETRANDRIA.}

(FOUR MALES.)

30 Aucuba

31 Betula

32 Boehmeria

33 Buxus 9

34. Cicca

35 Empleurum

$\begin{array}{ccl}\mathrm{s} & 1 & \text { Japan } \\ \mathrm{t} & \mathbf{7} & \text { Virginia } \\ \mathrm{h} & 1 & \\ \mathrm{~s} & 1 & \text { Europe } \\ \mathrm{t} & 1 & \text { India } \\ \mathrm{s} & 1 & \text { Cape }\end{array}$

Brit. 3

Brit. 1

* See note to Xylophylla.

+ Coix lacrima (Job's tears) is frequently cultivated in Spain and Portugal, and the seeds ground for a coarse sort of bread.

$\ddagger$ Scleria hath either one or three stamina.

$\S$ Zea mays (Indian corn) hath several varieties.

\| The Laplanders make great use of the carex vesicaria (bladder carex) to stuff in their shoes in winter to keep out cold, and in summer to keep their feet from sweating; they also stuff their gloves with it to preserve the hands.

I Buxus sempervirens (box tree) is said by some to have the same virtues as the guajacum officinale. 


\begin{tabular}{|c|c|c|c|}
\hline Genera. & Growth. & $\begin{array}{l}\mathrm{N}^{\circ} \text { of } \\
\text { species. }\end{array}$ & Native of \\
\hline 36 Littorell & $h$ & 1 & Dantzic \\
\hline 37 Morus* & $\mathrm{t}$ & 7 & China, America \\
\hline 3 Serpicula & h & 2 & India \\
\hline 39 Urticat & s \& $\mathrm{h}$ & 28 & Canada, Cape \\
\hline
\end{tabular}

\section{ORDER V. PENTANDRIA.}

(FIVE MALES.)

40. Amaranthus
41 Ambrosia
42 Chayote
43 Clibadium
44. Iva
45 Leea
46 Nelicytus
47 Nephelium
48 Parthenium
49 Xanthium

$\begin{array}{crl}\text { h } & 24 & \text { Ganges, \&c. } \\ \text { h } & 4 & \text { Virginia } \\ \text { h } & 1 & \\ & 1 & \text { Surinam } \\ \text { s \& h } & 2 & \text { America } \\ \text { s } & 2 & \text { Cape, India } \\ \text { s } & 1 & \\ \text { s } & 1 & \text { India } \\ \text { h } & \mathbb{2} & \text { Jamaica } \\ \text { s \& h } & 5 & \text { E. Indies }\end{array}$

Brit. 1

ORDER VI. HEXANDRIA.

(SIX MALES.)

Calyx glume, none:

50 Bactris

51 Pometia

h $\quad 1$

* Mr. Evelyn, in his Sylva, says that the timber of the mullerry tree (morus) will last in water as long as the most solid oak; and that it suffers no kind of vermin to breed on it, whether standing or felled, nor does it harbour any caterpillar, except the silk-worm. The greacest part of the paper in Japan and China is made of the bark of the mulberry paper-tree (morus papyrifera), but besides this, they use the bamboo reed, the cotton shrub, hemp, and the straw of wheat and rice, \&c. In general only the bark of trees and shrubs is used, but of bamboo and cotton: shrut he woody part is employed: but the best and most esteemed paper is made from cotton.

t The three British species of urtica are the urtica pilalifera (the Roman stinging nettle), urtica ur ens (the annual stinging nettle), and urtica dioica (the perennial stinging nettie) : and their stinging is said to be performed in the same way as in insects; by a bag at the base, and a perforation near the point, through which is ejected the deleterious fluid. 
No of

No Genera.

Growth. Species.

Species in

52 Zizania*

h 3 Jamaica, N. America

Calyx glume, one-flowered.

53 Pharus

h 1 Jamaica

ORDER VII. HEPTANDRIA.

(SEVEN MALES.)

54. Guettarda

t. 1 Jamaica

ORDER VIII. POLYANDRIA.

(MANY MALES, -MORE THAN SEVEN.)

55 Begonia

56 Ceratophillum

57 Fagust

58 Liquidambar

59 Myriophyllum

60 Poterium

61 Quercusł

$\begin{array}{crl}\text { h } & 4 & \text { India, Cape } \\ \text { t \& h } & 2 & \text { Europe } \\ \text { t } & 3 & \text { Italy } \\ \text { t } & 2 & \text { Virginia } \\ \text { h } & 2 & \text { Europe } \\ \text { h } & 3 & \text { Europe } \\ \text { t } & 19 & \text { Molucca, \&c. }\end{array}$

Brit. 2

Brit. 2

Brit. 2

Brit. 1

Brit. 1

* Zizania aquatica (wild rice) is a grass produced on the banks of the lakes of N. America, its seed is larger than rice, and nearly equal in flavour, and is much sought for by the inhabitants for food. Linnæus Amæni. Acade.

t Evelyn, in his Sylva, says that the leaves of the beech (fagus) being gathered about the fall, afford the best and easiest bed mattresses in the world; and are much used in Dauphine and Switzerland. He also cites Juvenal, who says "Sylva domus, cubilia frondes."

$\ddagger$ Kermes (a species of insect called coccus infectorius) is found on an evergreen oak (quercus coccifera), and was much used in dyeing before cochineal was known. (See scleranthus and cactus). Both this and cochineal were for a long time considered as a grain; hence clothes dyed with these drugs were said to be dyed in grain.-Quercus suber is the cork tree, which Mr. Miller says requires stripping of its external bark (out of which they cut corks) every eight or ten years, for the health of the tree, which would otherwise sooner perish;-But Mr. Dillon (in his travels through Spain, printed in 1782) says that they strip off the bark erery four years as far as a white sap, which they leave on the tree; a liquid humour afterwards issues out, which thickens with the sun and air, and forms a new bark in about four years.- See note to spondias. Quercus nigra (black oak) is so called in Pensylvania, New Jersey, New York, and New England. Mr. Bartram (in his travels through America, printed in 1792) says that he measured several black oaks that were eight, nine, ten, and eleven feet diameter, five feet above the ground, 


$\begin{array}{lcclcc}\text { No Genera. } & \text { Growth. Species. Native of } & \begin{array}{c}\text { Species in } \\ \text { Britain. }\end{array} \\ \text { 62 Sagittaria } & \text { h } & 5 \text { America, China } & \text { Brit. } 1 \\ \text { 63 Theligonum } & \text { h } & 1 \text { Italy } & & \\ 64 \text { Xylosma } & & 1 & \end{array}$

Amentum imbricated.
65 Carpinus
66 Corylus
67 Juglans*

s 2 America

s 3 Europe

$\mathrm{t} 5$ America
Brit. 1

Brit. 1

\title{
Amentum globular.
}

68 Platanus

\author{
t 2 E. \& W. Indies
}

\section{ORDER IX. MONADELPHIA.}

(ONE BROTHERHOOD.)

Stamina united at the base.
69 Acalypha
70 Crotont
71 Cupania
72 Dalechampia
73 Heritiera
h 5 Virginia, India
s \& h 23 Japan, America, Cape
s 1 America
s 2 America
s 1 Zeylon

from whence they ascended perfectly straight, with a gradual taper, forty or fifty feet to the limbs; the bark (called the quercitron bark) is found to afford a valuable yellow dye; discovered by Edward Bancroft, M. D. F. R.S. who obtained an exclusive privilege for importing, using, and vending it. Professor Martin is of opinion that our common English oak (quercus robur) produces by much the best timber of any of the species; the leaves are deciduous, have no foot-stalks, and the acorns generally grow single, or at most two together, on long foot-stalks. - There is also an oak, not uncommon in England, which hath the leaves on foot-stalks, and the acorns in clusters, sitting close to the branch; but the timber is much inferior. In some counties the woodmen call it durmast.

* It is said that if a seedling plant of the walnut (juglans), or the mulberry (morus), or any other trees that are many years before they bear fruit, are ingrafted with scions taken from a fruit-bearing tren of the same kind, that they will bear fruit in a very few years.

+ In China are many plantations of the croton sebiferum (tallow tree) of which the Chinese make their candles, which are of a superior quality; this tree is there called latchoo, and is remarkable for the beauty of its appearance; it is the size of an apple tree, having scarlet leaves edged with yellow, and bloss,oms of a pale purple.-Macartney's Embassy, printed in 1795. The stone of the fruit is surrounded by a white pulp, which hath all the properties of true tallow, both as to consistence, colour, and even smell. 


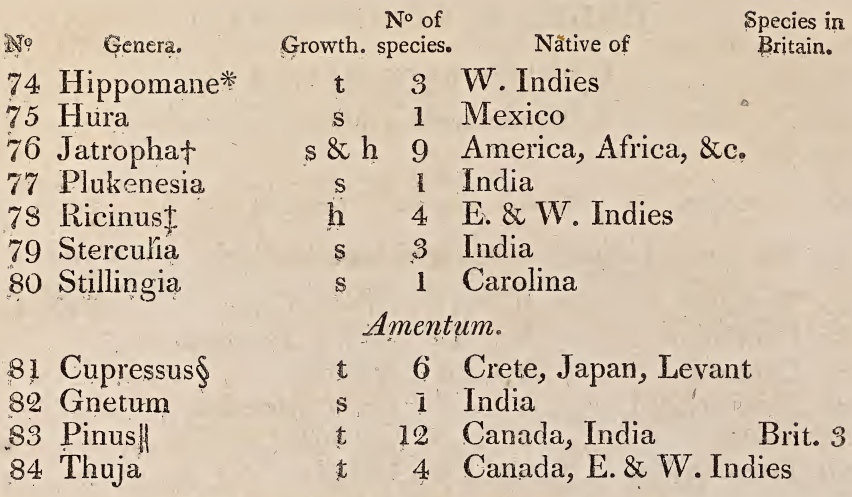

* The manchineel tree (hippomane mancinella) is one of the most poisonous trees that grows; not only the fruit, but the wood and every part is noxious. The Indians use the milk or juice to poison their arrows.

$\uparrow$ The ropt of the manihot or manioc (jatropha manihot), properly prepared, is much used in the W. Indies for bread, then called cassada, and esteemed very wholesome; although in its recent state it is said to be a strong poison : but the sort that grows in Africa is often eaten raw without any ill effect, and from the starch of the root is made a granulated powder, called tapioca, which, dissolved in hot water, is said to be very nourishing.

\# An oil, called castor oil, in the West Indies, is expressed from the seed of the ricinus communis, formerly called palma christi, or agnus castus.

$\S$ The wood of cypress (cupressus sempervirens) is almost incorruptible either in air or water. The coffins in which the Athenians used to bury their heroes, Thucydides says, were made of this wood; as were likewise the chests containing the Egyptian mummies.-See note to ficus. The doors of St. Peter's church, at Rome, were originally of the same wood, but after lasting eleven hundred years, without any visible tendency to decay, they were xemoved by order of Pope Eugenius the 4 th, and gates of brass substituted in their place. Milne's Bot. Dict.

II Venice turpentine is from the larch tree (pinus larix); Burgundy pitch is from the fir (pinus abies).

Former botanists, before Linnæus, distinguished the fir from the pine, by the insertion of the leaves; those of the fir are produced singly from the branches; those of the pine grow by twos, threes, or fives, out of a little sheath that surrounds their base, and when fitted together, they form a cylinder.-Linnæus hath included both sorts under one genus (pinus), but hath made the same distinction in the species as above; except having added the cedar and larch to the same genus, the leaves of which proceed from a sheath, but growing in bunches, he calls fascicled.-Great varieties proceed from the seeds of the several species of the pine and fir.

Pinus pinea (the stone pine) hath in general only two leaves in a sheath, but a few intermixed have three.-The kernels of this pine are said to be frequently used in the winter desserts of the table both in France and ltaly.

The kernels of the pine are used in medicine, and sometimes for food; and it is said in Lapland a nourishing bread is made of the pounded bark. 


\section{ORDER X. SYNGENESIA.}

\section{(CONFEDERATE MALES.)}

Stamina united at the top.

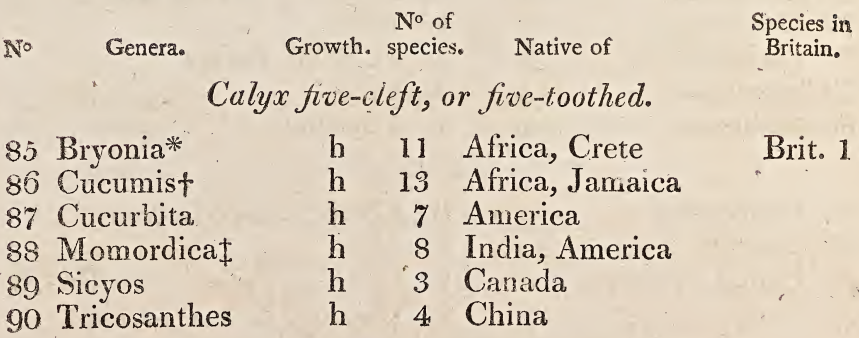

\section{ORDER XI. GYNANDRIA.}

\section{(FEMININE MALES.)}

The stamina growing on a sort of style, or imperfect pistillum.

\section{Calyx five-leaved.}

$\begin{array}{ll}91 \text { Andrachne } & \text { h } 2 \text { Italy } \\ & \text { Calyx six-leaved. } \\ 92 \text { Agyneia } & \text { s } 2 \text { China }\end{array}$

* The young tops of white lryony (bryonia alba) may be boiled and eaten as hop tops, or asparagus. See note to arctium.

+ The drug cologuintida, or colocinth, is the pulp of a species of cucumis, called cucumis colocynthes.

¥Momordica elaterium (spurting cucumber) receives its English name from being of the shape of a cucumber, but less. Like many other plants it is endued with a remarkable elastic force for the dispersion of the seed, which force, in some plants, is resident in the calyx, as in oates, and many of the ferns, \&c.; in others, in the pappus (down), as in centaurea, crupina, \&c.; and in others, in the capsule or pericarpium, as in nomordica elaterium, which, when ripe, by touching the stalk near the capsule, or raising up the capsule so as to disturb the end of the staik, it is immediately detached a little within the capsule, and, in a surprising manter, the seeds and part of the juice are thrown out to a considerable distance with great violence: which seems to be owing to the elasticity of confined air; which, as Virgil says, "Qiia data porta, ruit." See note to impatiens, and to the semina of plants 


\section{CLASS XXII. DIOECIA.}

(TWO HOUSES.)

This class consists of such genera, as have male and female flowers distinct on two separate plants.

\section{OBSERVATION.}

There are many plants which have male and female flowers distinct on two separate roots, yet are not admitted to this class, because they are only species of some particular genus, which agree in all other instances with the generic character to which they belong; as valeriana, (triandria); rhammus, rhus, lonicera, phylica, (pentandria); rumex, (hexandria); laurus, (enneandria); guilandina, cucubalis, lychnis, phytolacca, gypsophyla, (decandria); spircea, rubus, (icosandria); clematis, thalictrum, (polyandria); napaa, (monadelphia); gnaphalium, (syngenesia); carex, urtica, morus, (monœcia).

It may also be observed, that none of the species of the rough-leaved plants of Ray, in class and order pertandria, monogynia, or in the classes didynamia, tetradynamia, and diadelphia; have any of the species been found to have distinet sexes on different plants.

\section{This class contains fourteen orders,}

Founded on the number, union, and situation of the stamina in the male tlowers.

- order 1. MONANDRIa.

\section{(ONE MALE.)}

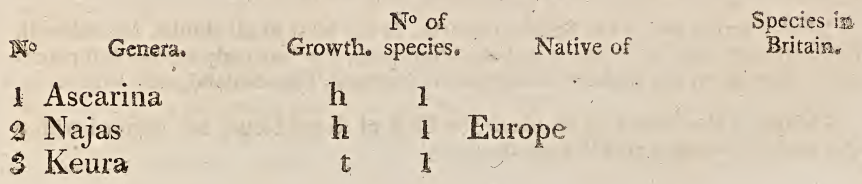




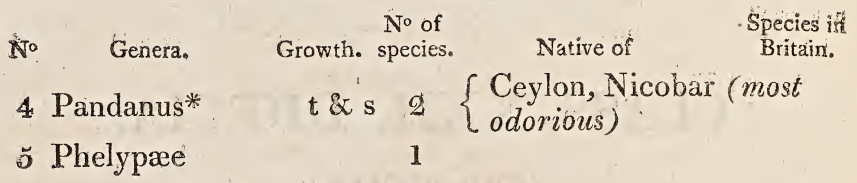

\section{ORDER II. DIANDRIA.}

(TWO MALES.)

Spatha.

$\begin{array}{llll}6 \text { Cec:opia } & \text { s } & 1 & \text { Jamaica } \\ 7 \text { Vallisneriat } & \text { h } & \text { i Italy }\end{array}$

Amentum.

8 Brosimum

$t \quad 1$ Jamaica

9 Salix $\ddagger$

t \& s 45 Egypt, Lapland

Brit. 40

\section{ORDER III. TRIANDRIA.}

\section{(THREE .MALES.)}

\section{Caturus \\ 11 Empetrum \\ 12 Maba \\ i3 Osyris}

14. Exccecaria

15 Restioß

$\begin{array}{lll}\text { s } & 2 & \text { E. \& W. Indies } \\ \text { s } & 2 & \text { Europe } \\ \text { s } & 1 & \text { Tonga Tabu } \\ \text { s } & 1 & \text { Italy, Japan }\end{array}$

Amenturi.

s 1 Amboyna

s \& h 9 Cape, \&c.

\section{Brit. 1}

* Pandanus leram (Nicobar bread-fruit) is said to be of the palm kind.

+ The male vallisneria spiralis, being always under water, hath a rery short stalk, on the top of which its flowers are produced, and when nearly arrived at maturity, they are separated from the stalk, and come unopened to the surface of the water; soon afterwards they expand themselves, and swim about the female flowers, which are blown at the same time, and lie on the surface of the water to receive the farina. The female flowers have long spiral stalks, which, relaxing, permit them to rise to the surface, and remaining there in full dress, receive the visits of the male; and in a few days return again under water.

$\mp$ Sulix herbacaea, as Dr. Smith remarks, is the least of all shrubs, for although the sterns are only an inch, or inch and half long, they are truly woody and perennial. Found on the highest mountains of Scotland, Cumberland, and Wales.

$\S$ Many of the houses at or about the Cape of Good Hope, are covered with a sort of dark coloured reed (restio tectorum). 


\title{
ORDER IV. TETRANDRIA.
}

\author{
(FOUR MALES.)
}

No Genera.
16 Brucea*
17 Hippophæ
18 Montinia
19 Trophis
20 Viscum

21 Batis

22 Myricat
No of

Growth. species.

Native of

Species in

Britain.

$\begin{array}{lll}\text { s } & 1 & \text { Abyssinia } \\ \text { s } & 2 & \text { Canada } \\ \text { s } & 1 & \text { Cape } \\ \text { s } & 2 & \text { Jamaica, Asia } \\ \text { s } & 9 & \text { Cape }\end{array}$

Brit. 1

Brit. 1

\section{Involucrum.}

s 1 Jamaica

\section{Amentum.}

\& 7 Ethiopia, America Brit. 1

\section{ORDER, V. PENTANDRIA.}

\author{
(FIVE MALES.)
}

\section{Acnida \\ 24. Antidesma \\ 25 Astronium \\ 26 Canarium \\ 27 Cannabist}

* The bark of the root of the brucea antidysenterica (called by the natives woo. ginoos) is a specific for the dysentery. The specific name antidysenterica was given by Sir Joseph Banks, but L. Heritier hath changed the name to lrucea fero ruginea. Bruce's Travels, 1790, vol. v.

N. E. The new red bark called angustura bark is supposed to be the production of the brucea.-Olservations on the angustura bark, by Augustus Everad Brand, 1791. But it hath been since said, that it seems to be neither the production of the magnolia glauca nor grandiflora; nor the brucea.-Dr. Simmons's Medical facts, 1791 .

+ The substance which is obtained from the female plant of candleberry myrtle (myrica cerifera) is from the covering of the berries, which is a granulated, white, unctuous substance; and after twice boiling, becomes a transparent green, and is a medium between wax and tallow. The leaves of the plant emit a grateful odour when bruised.

¥ A female hemp hath sometimes had one or two male flowers, and consequently good seed, from which some persons have doubted of the sexes of plants. The only two intoxicating articles of which the Kaffers in Africa have any knowledge, are tobacco and hemp (cannabis sativa). The effects produced from smoking hemp are said to be fully as narcotic as opium.-Barrow's Travels in Africa, printed 1801. 
No of

No Genera. Growth. Species.

Species in Britain.

28 Flevillea

29 Humulus*

30 Iresine

31 Pistaciat

32 Spinacia

33 Zanonia

34. Zanthoxylon

h 2 W. Indies

h 1 Europe

Brit. 1

h 1 Virginia, Jamaica

t 5 Chios

h. 2 Siberia

h 1 India, Malabria

s 2 Virginia, Jamaica

\section{ORDER VI. HEXANDRIA.}

(SIX MALES.)

Calyx six-leaved.

35 Dioscorea

36 Rajania

37 Smilax

38 Tamus

h 12 India

h 5 America

s \& h 14 Spain, Ceylon, N. Amer. h 3 Crete, Cape

Brit. 1

\section{ORDER VII. OCTANDRIA.}

(EIGHT MALES.)

Calyx four-parted, or four-toothed.

39 Margaritaria

40 Rhodiola

41 Populusई s 1 Surinam

h 1 Europe

Amentum.

t 11 Italy, \&c.
Brit. 1

Brit. 3

* Hop-linds properly macerated in water, like hemp, will make cloth or paper. The part of the hop which is used as a bitter, is the leafy calyx of the female, which is expanded and lengthened.

\section{+ Mastich (a resin) is from the pistacia lentiscus.}

¥The large tuberous roots of the smilax China, properly prepared, afford 2 nourishing food to the Indians.

$\S$ The blossoms of the populus nigra (black poplar) yield by pressure an oil, or resin, which consolidates in the usual temperature of the atmosphere, and which, when made into candles, is found to give a light cheaper than that of tallow, and more brilliant than that of wax, - It is a native of Britain, and flowers in Aprilo. 


\section{ORDER VIII. ENNEANDRIA.}

(NINE MALES.)

No Genera. Growth. species. Native of $\quad \begin{gathered}\text { Species in } \\ \text { Britain. }\end{gathered}$

Calyx three-leaved.

42 Hydrocharis

h 1 Europe

Brit. 1

43 Mercurialis

s \& h 4. Africa, Spain

Brit. 2

ORDER IX. DECANDRIA.

(TEN MALES.)

44. Carica

45 Coriaria

46 Kiggelaria

47 Schinus

Calyx five-leaved, or five-cleft.

ORDER X. DODECANDRIA.

(TWELVE MALES.)

48 Datisca

49 Euclea

h 2 Crete

50 Menispermum

$\mathrm{s} 2$ India

s 2 France

t 1 Ethiopia

s 2 Peru

t 1 Cape

s 11 America, Japan

ORDER XI. ICOSANDRIA.

(TWENTY MAISES.)

51 Flacourtia

s I

ORDER XII. POLYANDRIA.

(MANY MALES.)

52 Cliffortia

53 Hedycarya

s 18 Cape, \&c.

s 1 New Zealand

ORDER XIII. MONADELPHIA.

(ONE BROTHERHOOD.)

Stamina united at the base.

54. Adelia

55 Cissampelos

s 3 America

s \& h 5 America 


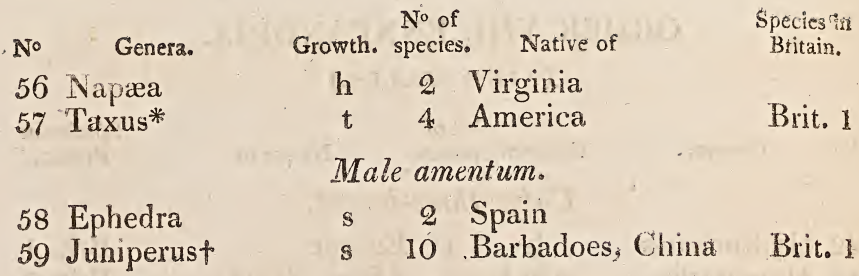

\title{
ORDER XIV. SYNGENESIA.
}

\author{
(CONFEDERATE MALES.)
}

Stamina united at the top.

Calyx six-leaved.

60 Ruscust

s 5 Italy, Spain

Brit. 1

\section{ORDER XV. GYNANDRIA.}

\author{
(FEMININE MALES.)
}

The stamina growing on a sort of style, or imperfect pistillum.

$$
\text { Calyx five-leaved. }
$$

\section{Clutia

s 9 Africa

* Taxus vaccata (the common yew tree) is very deleterious to cattle, but they will not eat the young shoots as they grow, but only when cut off and beginning to wither, as they then lose part of their acrimony, but there is often sufficient poison left in them to destroy the animal.

Phytologia.

+ Olibanum (a gum resin) is from a species of juniperus, called juniperus lycia , and the sandarack resin is from the juniperus communis, which being dissolved in oil of turpentine, or linseed oil, or spirit of wine, is the common varnish ; and being reduced to powder, is the pounce commonly used. The cedar of Bermudas (juniperus bermudiana) in which black-lead pecils are enclosed, is not eaten by any insect.

¥ The ruscus is a very singular plant as to its mode of flowering, which I shall instance in the ruscus aculeatus, which is the only British species of this genus; it appears to have its flower protruded from about the middle of the upper surface of the leaf, yet hath a perfect peduncle, which is connected with the wood of the branch, at the bosom of the leaf; but being covered with the exterior coat, or epidermis of the leaf, is scarcely visible to the eye, but is very apparent in the rusw cus hypoglossum. Linnæus enumerates five species, viz.:

Ruscus aculeatus, .. Leaves flower-bearing above, naked.

...... hypophyllum, Leaves flower-bearing underneath, naked.

...... hypoglossum, Leaves flower-bearing above, under a foliole or leaffet, called by Linnæus under-tongue.

...... androgynus,.. Leaves flower-bearing on the margin.

..... racemosus, .. Raceme terminal, monochinian. 


\section{CLASS XXIII. POLYGAMIA.}

\section{(POLYGAMIES。)}

This class consists of such genera as have monoclinian Howers, and also either male or female flowers, or both, distinct, either on the same, or on different plants: so that to be of this class, a plant ought to have some of its flowers monoclinian, to distinguish it from those of the classes monacia and diccia. Yet there are a few exceptions, as in the third distinction under the second order, and in the third order.

The polygamy of moniclinians and males on the same plant is also observable in several of the umbelliferous plants (pentan. digyn.), particularly carrot, sanicle, hog's fennel, coriander, chervil, shepherd's needle, alisander, bastard parsley, and carui.-These plants therefore, strictly, ought to have been arranged under this class; but Linnæus more properly judged the natural umbelliferous character to be prevalent.

This class contains three orders.

\section{ORDER I. MONCECIA.}

\section{(ONE HOUSE.)}

Having the polygamy on the same plant.

No Genera. Growth. Species. Native of Britain.

1st. Male monoclinians, and female monoclinians.**

Spatha.
1 Musat
h 3 India

* Called so from the sex that is predominant, as a male monoclinian hath the female abortive or ineffectual; and a female monoclinian the male. For it is to be observed, that the monoclinian flower commonly fails in one sex, whence the male or femule flower becomes necessary.

TThe banana (musa sapientum) is a fruit much esteemed by the Indians; in the island of Madeira it is called the forbidden fruit, and is thought a crime to cut it with a knife, because, after dissection, they fancy it represents our Saviour's crucifixion, and that they thereby wound his sacred image. The plantain tres (musa paradisiaca) will rise fifteen or twenty feet, and generally flowers within the year, and the leaves, when the plant is in full vigour, are often eight feet long, and 


\begin{tabular}{|c|c|c|c|c|c|}
\hline $\mathbb{N}^{\circ}$ & Genera. & G & $\begin{array}{l}\text { No of } \\
\text { specieso }\end{array}$ & Native of & $\begin{array}{l}\text { Species in } \\
\text { Britain. }\end{array}$ \\
\hline \multicolumn{6}{|c|}{ 2d. Monoclinians and males. } \\
\hline 2 & Acer* & $\mathrm{t}$ & 17 & Crete, Japan, Amer & Brit. 2 \\
\hline 3 & Celtis & $\mathrm{t}$ & 3 & ¿.\&W.Indie & ies \\
\hline 4 & Gounania & $\mathrm{s}$ & $1]$ & Domingo & \\
\hline 5 & Griselinia & s & 1 & & \\
\hline 6 & Mimosat & s & 551 & Africa, America & \\
\hline 7 & Ophioxylum & s & 1 & Ceylon & \\
\hline 8 & Pennantia & & 1 & & \\
\hline 9 & Terminaliaf & s & 21 & France, E. Indies & \\
\hline 10 & Valantia & h & 81 & Europe & Brit. I \\
\hline 11 & Veratrum & $\mathrm{h}$ & 3 & Russia & \\
\hline
\end{tabular}

near three broad; but when it hath once flowered, the stem soon dies to the ground. The fruit of both these trees is used for bread in the West Indies, and both have equally large leaves. Dr. Milne says the most antient authors called the fruit of the banana a fig; and it is supposed from the leaves of these trees our first parents in Paradise made for themselves aprons.

* Acer saccharinum (the sugar maple) grows in North America, and is very common in Canada, where there are two kinds, one called the swamp maple, from its growing on low ground; the other, the mountain or curled maple, from its growing on high ground, and the wood being variegated with little stripes and curls. The former yields most sap in proportion to its size, but the sap does not afford so much sugar as the curled kind; a pound of sugar may be obtained from two or three gallons of the curled maple, but it will take six or seven gallons of the swamp maple to procure the same quantity. A maple tree of about twenty inches in diameter, will commonly yield sap for five pounds of sugar each year.

Travels through North America, by Isaac Weld, junr.-1799.

+ The drug terra japonica is not an earth, but a concreted vegetable juice, partly gummy and partly resinous, from the mimosa catechu, and other plants. Gumarabic is also from the mimosa nilotica. The gum-arabic which comes in the way of trade, is not collected on trees, as is commonly imagined; it is found by digging cavities at the foot of the old trees, particularly of the mimosa nilotica and senegal, where large masses of the gum which have exsuded from the roots, perhaps during some ages, and which are detached from the base of the tree, are then discovered. Though this gum bears the name of gum-aralic, it is chiefly obtained from Abyssinia. The species of mimosa are with the greatest difficulty combined with the character of the genus. Some with calyx and corolla four-cleft, five-cleft, manypetaled, petalless.-Some with stamens four, five, ten, very many, rather two brotherhood.-Some with legume membranous, winged, berried, jointed; the seeds also vary in shape. See note to sensitive plants, in the Index.

\pm Benzoinum (Benjamin) is a resin from terminalia benzoin, and is sometimes called assa-dulsis, in opposition to assa-foetida.-Edin. Phar. Former botanists thought the laurus benzoin to be the true benzoin, but Linnæus detected the error, and thought it to be the terminalia benzoin; but, according to Mr. Dryander, Linnæus is also mistaken, for he evidently finds it to be a species of the styrax, and gives a particular description of the tree growing in Sumatra. 
POLYGAMIA.

\begin{tabular}{|c|c|c|c|c|}
\hline \multirow[t]{2}{*}{ No } & Genera. & Growth. Species & Native of & $\begin{array}{l}\text { Species in } \\
\text { Britain. }\end{array}$ \\
\hline & \multicolumn{4}{|c|}{ Gluma. } \\
\hline 12 & Egilops & 4 & Spain, Italy & Brit. 1 \\
\hline 13 & Andropagon & 25 & India, America & \\
\hline 14 & Apluda & 4 & E. \& W. Indies & \\
\hline 15 & Cenchrus & s \& h 9 & Italy & \\
\hline 16 & Holchus* & 13 & India & Brit. 2 \\
\hline 17 & Ischœmum & 2 & China & \\
\hline 18 & Manisuris & $\mathrm{h}$ & India & \\
\hline 19 & Spinifex & h & E. Indies & \\
\hline \multicolumn{5}{|c|}{ Umbelled. } \\
\hline 20 & Hermas & h $: 5$ & Cape & \\
\hline & & Amente & $u m$. & \\
\hline 9 & Brabeium & 1 & Cape & \\
\hline
\end{tabular}

3d. Monoclinians and females.

22 Atriplext

23 Clusia

24. Virgilia

25 Wedelia

26 Parietaria

Brit. 8

s \& h 12 Siberia

t 4 America

1

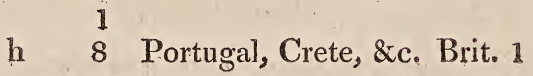

4.th. Monoclinians and males and females.

27 Breynia

h. 1

ORDER II. DICECIA.

(TWo Houses.)

Having the polygamy on two plants.

1st. Monoclinians and males.

28 Chrysitrix (glume) h 1 Cape

29 Diospyros t 5 Italy, Virginia, E. Indies

30 Nyssa $\quad t \quad 1$ Virginia

* Indian millet (holchus sorghum) is much cultivated in Egypt under the name of doura.

+ Atriplex without the female flower is chenopodium, and chenopodium with the female flower is atriplex; therefore there is the greatest affinity between them. This genus is omitted in the 8th edit, of Gen. Plant. 
No of

No Genera. Growth. species. Native of Britain.

31 Panax* (umbel'd) s\&h 5 China, America

32 Stilbe

3 Cape

2d. Monoclinians and females.

33 Fraxinust

t 4 America

Brit. 1.

34. Gleditsia $\ddagger$

t 2 America

3d. Androgynous and males.

35 Anthospermum s \& h 3 . Ethiopia

Umbelled.

36 Arctopus

h 1 Africa

No calyx.

37 Pisonia

s \& W. Indies

\section{ORDER III. TRICECIA'.}

(THREE HOUSES.)

Having the polygamy on three plants.

Androgynous, male, and female, on three plants.

38 Ceratonia

t 1 Spain

* The roots of fennel (anethum foeniculum) is said to be a good succedaneurn for ginseng (panax quinquefolia). Dispensatorium Fuldense, 1791.

+ Manna, from Calabria, is a concreted juice chiefly from a species of ash, called fruxinus rotundifolia. This is the sort at present most used, though formerly that obtained from the hedysarum alhagi was in great esteem, called Syrian or Persian manna, which granulated like mastick. Manna is also obtained in Spain from the ald branches of the cistus ladiniferus.

In gleditsia, the monoclinians and males are on the same plant, and the females on another.

$\S$ Amber tree (anthospermum) is called so from its fragrant odour: real amber being ranked as a fossil bitumen; though perhaps originally might have been of vegetable production.

II Ceratonia siliqua (the carob tree) called by former botanists siliqua; which, Mr. Bruce says, in Africa is called kuara, from the country where it grows. It bears a long, flat, brown-coloured pod, the seeds of which are so nearly of a size, as scarcely to vary in weight; hence they became a weight for gold, called curat, 


$\begin{array}{lll}\text { No Genera. } & \text { Growth. Species, Native of } & \begin{array}{c}\text { Species in } \\ \text { Britain. }\end{array} \\ 39 \text { Ficus } & \text { s } & 17 \text { Europe, India }\end{array}$

carrat, or caract, from the Greek word kerateon (siliqua).-In Britain the term is used to express the degree of fineness, pure gold being fixed at twenty four carcits ; if therefore two parts are alloy (which is about the standard of the current gold) it is said to be twenty-two carats fine.-The term is also borrowed as a weight for precious stones, containing four grains.

* Linnzus saith he hath removed ficus (fig tree) from the class cryptogamia to the class polygamia, being convinced of the structure of the fructification, the umbilicus of the receptacle in some being open. Therefore the fruit of the ficus is not a pericarpium, but a receptacle, the interior sides of which support the flowers, which are enclosed within it.

Mr. Lee says, the flowers in our common fig trees are female only, but that formerly known by the name of eaprificus hath male flowers; and another, called erinosyne (which is androgynous) hath both male and female flowers distinct, though lodged within the same receptacle.-Here, then, we have the tricecious polygamy explained; and if descriptions of De la Hire may be trusted, there are figs which contain monoclinian flowers; which makes a fourth habitation for the sexes.

As these trees, in warm climates, bear some mate and others female flowers, immured on all sides by the fruit, the manner of their fecundation was very unintelligible; until Tournefort, Pontedera, and Linnerus, discovered that a kind of gnat, of a black colour, was produced in the male figs; and, at a certain time, made their escape, and carrying the fecundating dust on their wings, and penetrating the female fig, thus impregnated the flowers. The figs of this country being all female, their seeds are not prolific; and therefore can only be propagated by layers, suckers, or cuttings. See Milne's Bot. Dict. under caprification.

Ficus religiosa (the banian tree) is said by some to bear no flowers or fruit, or very small, and is very remarkable; shoots from the boughs of which, teriding to the earth, take root and grow up again like the mother plant, and spreading themselves far around, will afford shelter for a regiment of soldiers under its branches, whose leaves are ever-green. Under these the Banians and Gentoos frequently place their idols, and perform religious ceremonies. Ficus sycomorus (the Egyptian sycomore) adorns the banks of the Nile, and produces a fig which grows on the trunk of the tree, and not at the end of the branches, which, though somewhat dry, is eaten. This tree becomes very large and tufted; it seldom grows straight, but is generally bent and twisted; its branches extending very horizontally, afford excellent shelter; its leaves are divided, and its wood, impregnated with bitter juice, is not subjected to be worm eaten. 'This sycomore grows several ages.rTranslation of Savary's letters on Egypt, 1799). The word is derived from the Greek, meaning fig-mullerry, and Linnæus, retaining the name, calls it fieus sycomorus (fig fig-mulberry); and this is said to be the wood of which the Egyptians made their coffins, as not being liable to decay. Our English sycomore, which is the acer pseudo-platinus of Linnæus, perhaps obtained its name from some slight. resemblance to the leaves of the antient syco-morus.-See note to cupressus. 


\title{
CLASS XXIV. CRYPTOGAMIA.*
}

\author{
(CLANDESTINE MARRIAGES.)
}

This class consists of such genera in which the parts of fructification, either from their minuteness, or particular structure or situation, are imperfectly visible, or entirely concealed.

\section{This class contains four orders.}

\section{ORDER I. FILICES.}

\section{(FERNS.)}

Containing such plants as bear their fruit on spikes, or in spots or lines on the under surface of the leaves, though sometimes at the root.-It admits of the follow. ing character: The calyx, a scale growing out of the leaf, opening on one side, under which are pedunculate globules, each encompassed by an elastic ring, which. breaking with violence, scatters a powder. But as there are no certain distinctions in the fructification sufficient to establish the genera, Linnæus hath arranged thera according to the form and situation thereof, under the leaves or frondst.

No Genera. Growth. species. Native of $\quad \begin{gathered}\text { Species in } \\ \text { Britain. }\end{gathered}$

1st. Fructification spiked.

$\begin{array}{lllll}\text { 1 Equisetum } & \text { h } & 7 & \text { Europe } & \text { Brit. 6 } \\ 2 \text { Onoclea } & h & 2 & \text { Virginia } & \\ 3 \text { Ophioglossum } & h & 9 & \text { America, Japan } & \text { Brit. 1 } \\ 4 \text { Osmunda } & \text { h } & 21 & \text { Cape, Virg. Ceylon } & \text { Brit. 4 }\end{array}$

* The plants of this class are often of a dangerous quality.

$\uparrow$ Fronds.-See note to palmœ.

In general the fructification in this order of ferns is on the back of the leaf, but there are some exceptions.-In equisetum (horse-tail) it is in a spike, each fructification being orbiculated, and gaping at its many-valved base. Hedwig has determined the flowers of horse-tail and adder's-tongue to be monoclinian.

$\S$ Ophioglossum vulgatum (adder's-tongue) is the only English species; it hath so visible flower, but is easily known by its spike or tongue (whence the name) growing on the lower part of the leaf, and extending to about the same length, containing many small seeds. 


\begin{tabular}{|c|c|c|c|c|}
\hline Genera: & \multicolumn{2}{|r|}{$\begin{array}{l}\mathrm{N}^{\circ} \text { of } \\
\text { species. }\end{array}$} & Nativ & \multirow[t]{2}{*}{$\begin{array}{l}\text { Species in } \\
\text { Britain. }\end{array}$} \\
\hline 201 & ific & ins & the & \\
\hline $5 \mathrm{Acs}$ & $\mathrm{h}$ & 35 & N. \& S. A & Bri \\
\hline 6 Adi & $\mathrm{h}$ & 27 & Afri & Brit. \\
\hline nium & h & 28 & America, \&c. & Brit. \\
\hline & h & 6 & Virginia, Japan & \\
\hline nitis & h & 4 & Jamaica, Japan & \\
\hline 0 Lon & h & 4 & Jamaica & \\
\hline odium† & h & 78 & America, \& & Brit. 15 \\
\hline & b & 23 & W & Brit. 1 \\
\hline Trichomane & b & 15 & Canary, China & Brit. 2 \\
\hline
\end{tabular}

\section{3d. Fructifications radical.}

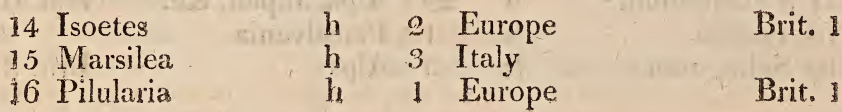

\section{ORDER II. MUSCI.}

\section{(MOSSES.)}

These are distinguished according as the antheræ (generally without filaments) ate or are not under a calyptra (vail or covering); as they are placed on the same plant with the female, or on a different plant (called one led or two leds), and as. the females are aggregate or solitary. This division, Linnæus tells us, is according to. Dellenius.

* Adianthum capillus veneris (Venus's hair) is supposed to be an ingredient in the syrup of capillaire, which you have at the coffee houses in London mixed with water;-from whence the name.

+The tartarian lamb, which is esteemed a vegetable curiosity, is only the root of a species of fern (called by Linnaus polypodium baromez, signifying a lamb), which is thick and covered with a soft dense yellow wool; and it sometimes happens that a part of the root is pushed out of the ground in its horizontal situation by some of the under branches, which gives the appearance of legs, and is hence said to resemble a lamb. - See a print of it in Philos. Trans, vol. 2.- -and also in Dr. Hunter's edit. of Evelyn's Sylva, printer in 1786. It is also said in Gordon's Geog. Gram, that it destroys all vegetables within its reach, and if the skin or rind is dressed with the wool on, as a lamb skin, it is difficult to distinguish them, and that many of the Muscovites use the skin instead of furs, for the lining of their vests. The down or wool is used for stopping hemorrhages, and is called golden moss.

I Pteris aquilina (common fern or bracken), the roots of which are much used as bread in New Zealand.-Cook's voyage. And in our dispensatories they are said to be aperient and anthelmintic. 
After the falling of the outer vail or covering, the anthere are found to be covered with another little hood, called by Linnæus operculum, which may be considered as a capsule, or perhaps, more properly, a recepiacle, supporting the flower and fruit ; for within the same little hood in buxbaumia, Linnæus saith he hath observed real antheræ hanging by filaments, opening at the top, and letting fall the pollen, and that the seeds lay at the bottom; but this wants further confirmation, as the male and female flowers have always been thought to be distinct.

The seeds of moss are little naked bodies without coat or cotyledon; and when mosses are dried, they will revive again with moisture.

No Genera. Growth. Species. Native of $\quad \begin{aligned} & \text { Species in } \\ & \text { Britain. }\end{aligned}$

1st. Without calyptra, (a vail).

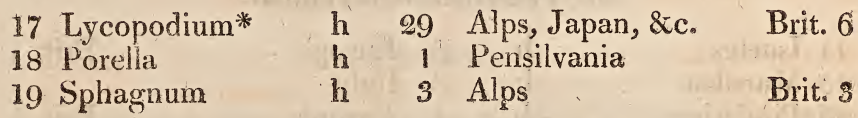

\section{2d. With calyptra, two bed.}

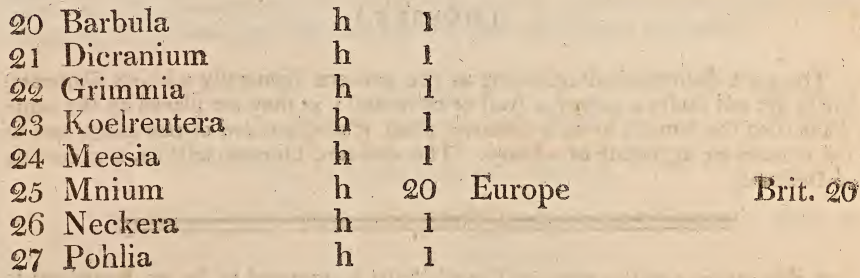

- The semina licopodii (commonly called witch-meal) are like a fine powder, and possess very extraordinary properties.-It is almost impossible to wet it; a quantity of it strewed upon a basin of water, not only swims upon the surface without being wet, but it prevents other bodies from being wet which are plunged into the water through it; so that a piece of money, or other solid body, may be taken from the bottom of the basin by the naked hand, without wetting the hand; which is one of the tricks commonly shewn by the jugglers in Bavaria: This meal covers the hand, and descending along with it to the bottom of the basin, defends it from the water. This substance has the appearance of an exceeding fine, light, and very moveable yellow powder, and it is very inflammable; so much so, that being blown out of a quill into the flame of a candle, it flashes like gunpowder; and it is made use of in this manner in the theatres for imitating lightning.

Count Rumford's Essays, vol. ii. p. 448. 


$\begin{array}{lcclc}\text { No Genera } & \text { Growth. species. Native of } & \begin{array}{c}\text { Species in } \\ \text { Britain. }\end{array} \\ 28 \text { Polytrichum } & \text { h } & 5 \text { Alps, Magellan } & \text { Brit. 3 } \\ \text { 29 Splachnum } & \text { h } & 6 \text { Sweden } & \text { Brit. 2 } \\ \text { 30 Timmia } & \text { h } & 1 & & \\ \text { 31 Tortula } & \text { h } & 1 & & \\ \text { 32 Weissia } & \text { h } & 1 & \end{array}$

3d. With calyptra, one bed.

\begin{tabular}{|c|c|c|c|}
\hline 33 Bryum & 37 & Alps, \&c. & Brit. 35 \\
\hline 34 Buxbaumia & 2 & Sweden, Italy & \\
\hline 35 Fissidens & $\mathrm{h}$ & & \\
\hline 36 Fontinalis & $\mathrm{h}$ & Europe & Brit. 4 \\
\hline 7 Hypnum & 50 & Europe, Jamaica & Brit. 41 \\
\hline 38 Leersia & h & & \\
\hline 9 Phascum & h & Europe & Brit. 4 \\
\hline Tetraphis & h & & \\
\hline Trichostomum & h & & \\
\hline Vebera & $h$ & & \\
\hline
\end{tabular}

\section{ORDER III. ALGE.}

\section{(FLAGS.)}

The fructification of these plants is so obscure, as not to admit of a precise arrangement; the ront, stem, and leaf, seem as one. They are only divided into serrestrial, and aquatic.

Linnæus hath taken his method from Michelius.

\section{1st. Terrestrial.}

$\begin{array}{llrll}43 \text { Anthoceros } & \text { h } & 3 \text { Italy } & \text { Brit. 1 } \\ 44 \text { Blasia } & \text { h } & \text { 1 Europe } & \text { Brit. 1 } \\ 45 \text { Byssus } & \text { h } & 14 \text { Italy } & \text { Brit. 14 } \\ 46 \text { Claydonia } & \text { h } 1 \text { Alps, \&c. } & \text { Brit. } 30 \\ 47 \text { Jungermannia } & \text { h } 33 \text { Alps }\end{array}$




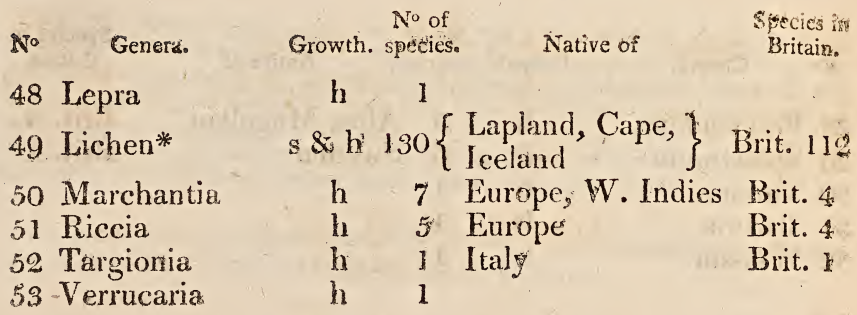

2d. Aquatic. $\dagger$
54. Confervat
h.
21 Europe
Brit. 21

* In the Systema Vegetalilium of Linnæus (edit. 14), one hundred and thirty species of lichen (liver-wort) are enumerated; and for the more easily, ascertaining them, they are ranked under different distinctions (as are several other species to genera, where they are numerous); 1 st. leprosi tuberculati (leprous tubercled) ; $2 \mathrm{~d}$. leprosi scutellati, such as have the appearance of little shields; $3 \mathrm{~d}$. imlricati, having small leaves lying over each other like tiles; 4 th. foliacei, consisting of one continued leafy substance; 5 th. coriacei, consisting of several leafy substances like leather; 6 th. umbilicati, hollowed like the navel, and dirty as with soot; 7 th. scyphifera, cup-bearing; 8th. fruticulosi, shrubbyish; 9th. filamentosi, thready, these mostly hang from the boughs of trees, hence the name of tree moss. The lichen rangiferinus, of the 8th. division, is the chief food of the rein-deer in Lapland, during winter.-This plant is very plentiful all over Lapland, vegetates beneath the snow, and is of a pure white, Nature's favourite colour in the northern regions, Several of the lichens, when dried, powdered, and steeped in urine, are used for dying reds and purple: as the lichen roccella of the 8th. division, called orchilla very common in Spain and the Canary Islands; the lichen periusus, with warts perforated, of the 3 st. division ; and the lichen tartarius, of the $2 \mathrm{~d}$. division, very common in Derbyshire. The lichen icelandicus (Iceland liver-wort) of the 4 th. division, is a highly nutritious substance; it requires a previous maceration in hot water, to take out the bitterness and laxative quality, it is then boiled with a fresh quantity of water, to give out its mucilage, and is afterwards mixed with broth of milk; boiled with milk alone, it affords a wholesome and palatable nodrishment to the Icelanders. It is here chiefly used, from its demulcent quality, by invalids and convalescents.

$+\mathrm{Mr}$. Corrêa de Serra hath shewn that the submersed alga, instead of pollex. or farina, are furnished with a mucus; and with vesicles instead of anthera.

Phil. Trans. for 1796, part 2.

\#The conferva bultosa was preserved dry for eighteen months, and which then resembled nothing but a small heap of greyish dust; this, however, after the vase which enclosed it was filled with water, gradually resumed its green colour, its little tubes filling up again, and new filaments growing. This was not a resurrection merely in appearance, like that of dry mosses, after they are wetted again, but real and complete, like that of certain animals.-(Read to the Philomathic Society of Paris in 7797 , by Girod Chantrans). The conferva agagropila is found loose in many lakes, in a globular form, from the size of a walnut to that of a melon 


\begin{tabular}{lcll} 
No Genera. & Growth. species. Native of & \multicolumn{1}{c}{ Species in } \\
Britain. \\
55 Fucus & $h$ & 58 Europe, Italy & Brit. 58 \\
56 Tremella* & $h$ & 11 Europe & Brit. 8 \\
57 Ulva & $h$ & 15 Europe & Brit. 15
\end{tabular}

\section{ORDER IV. FUNGI.† \\ (FUNGUSSES.)}

Linnæus tells us he rather chose to make his divisions in this order according to Dellenius, than from Michelius: hecause the first is plain to every one, hut the latter requires too nice an inspection; yet Michelius hath thrown great light on this tribe of vegetables, as also on mosses and flags. The generic character is therefare only taken from their external forms. They are generally erect.

\section{Ist, Hatted.}
58 Agaricus
h 39 Europe
Brit. 28

much resembling the balls of hair found in the stomachs of cows; it hath no adherence to any thing, but rolls from one part of the lake to another. The conferva

- vagabunda dwells on the European seas, travelling along in the midst of the waves; these may not improperly be called itinerant vegetables.-In a similar manner the fucus natans strikes no roots into the earth, but floats on the sea in very extensive masses, and may be said to be a plant of passage, as it is wafted about by the winds.-(Botanic Garden, 4 to. edit. p. 170). M.Vaucker, of Geneva, hath lately published an history of the fresh-water conferva, relating to its fructification, and hath found out no less than six different modes of generation.

* That substance that hangs down from the beams in wine vaults, is a species of tremella, which, being dried, becomes a tough membranous matter of a fungus smell; it seems to be of a middle nature between mushroom and star jelly, another species of tremella.-Though Linnæus makes star jelly (tremelia nostoc) a fungus, yet others suppose it to be voided by herons after having eaten frogs; and limbs of frogs are said sometimes to be found amongst it. But in Bewick's history of British birds, vol. ii, printed in 1804 , it is said to be believed to be the remains of half digested worms, slugs; $\alpha c$. which the gulls have discharged from their overloaded stomachs; and it is said these birds, when shot, have been found when dying to disgorge a substance of the like kind.-It is called star jelly, or star shot, being supposed by the vulgar to be dropped by the meteor, called a falling star.

+ Those circles or curves we often see on the ground, called fairy-rings, seem yery imperfectly understood: they have long been supposed to be caused by lightning; but now are conjectured to be caused by that species of fungi that grows upon them; which either by some means radiating from a centre, or gtowing in circles and curves, as directed by nature, produce the above phænomenon.

$¥$ M. Willemet (a member of the academy of Dijon in France) considers the \&garic on trees as the superaburdance of a vegetable juice that exists in the tree, or as a morbid matter which is in a state of depuration; consequently excludes is us a fungus. See note to mushroom, in the ladex. 


$\begin{array}{llll}\text { No Genera. } & \text { Growth. Species. Native of } & \begin{array}{c}\text { Species in } \\ \text { Britain. }\end{array} \\ 59 \text { Boletus } & \text { h } & 21 \text { China } & \text { Brit. 1s } \\ 60 \text { Hydnum } & \text { h } & 5 \text { Italy } & \text { Brit. } 3 \\ 61 \text { Phallus } & \text { h } & 3 \text { Europe } & \text { Brit. } 3\end{array}$

\section{2d. Having no hat.}

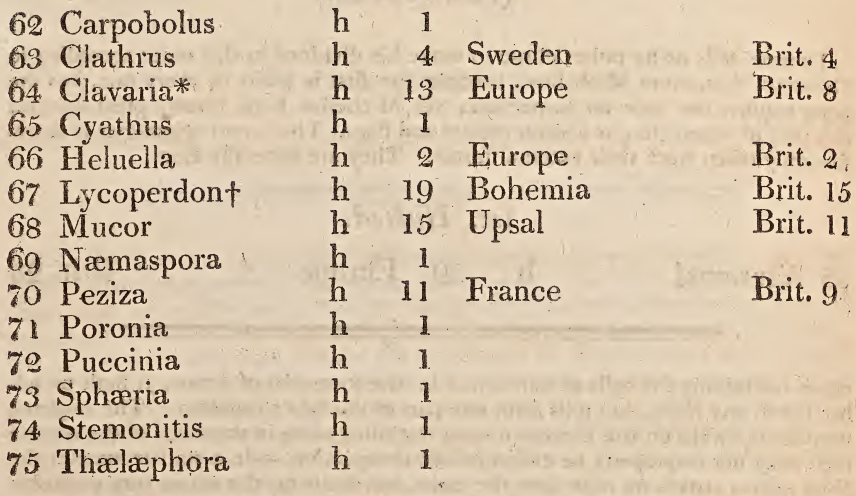

* Many fabulous accounts have been propagated of a vegetable fly in the Caribee islands; but from Dr. Watson and Sir John Hill it appears to be only a species of fungus, which Sir John calls clavaria sololifera, but by Linnæus clavaria militaris, which delights to grow on putrid animal substances, and hath been sometimes found on the husk of some of the species of the genus cicada in the chrysalis state, which then lie buried under dead leaves to wait their change; and when nearly arrived at maturity, will sometimes move with the fungus on the husk; hence imagination hath pictured them flying with a sprig upon their backs.

+ Truffle (lycoperdon tuber) is a subteraneous vegetable, consisting of a solid tubercle without stalk or root, covered with a rough blackish coat; they never appear above ground, but lie about half a foot beneath the surface, and generally great numbers are found in the same place, of different sizes, sometimes even to weigh a pound. In France and Italy they are esteemed great delicacies, and are found by the smell with dogs and swine, probably by their possessing somewhat of an animal scent.-(See note to zoophytes). A few truffles are sometimes found about Selborne, in Hampshire, and are sold at $2 s .6 d$. per pound. 


\section{APPENDIX.}

Consisting of such plants, which though capable of being arranged in the several classes of the system, yet on account of their singular structure, Linnæus hath rather chose to place apart in an appesidix, under the head of PALM such genera as have a spadix and spatha, (i.e.) whose flowers and fruit are produced on that particular receptacle or seat, called a spadix, protruded from a common calyx in form of a sheath, called spatha; and consists of trees and shrubs only.-These terms were originally only applied to palms, but now are applied to narcissus, snozedrop, orchis, \&c.

PALMF.**

(PALMS SPATHED, THREE-PETALED.)

No of

Wo Genera. Growth. species. Native of

Species in Britain,

Ist. Fan-leaved, (two houses.)

Drupa.
1 Borassus $\uparrow$
s 1 Malabar
2 Chamæropst
s 2 Spain

* Palms have always a simple stem, not branched, bearing leaves at the top, resembling those of fern, being a composition of a leaf and a branch, or where the leaves are confounded with the stem and branches, called frondes; and the corolla hath always three petals, or three deep divisions.

It is remarkable that if the male flowers of the palm are got at a proper time and dried, the pollen will be prolific if kept a year or upwards; and the same hath been observed of the male pistacia.

+ The leaves of the Borassus fabelliformis (Malabar palm, or Palmira), and of another palm called tallipot or talpot (licuala spinosa), are used on the coast of Asia and in Ceylon instead of paper. They require no other preparation than merely zo be separated, and cut even with a knife, and are written upon, while fresh, with 2 sharp steel or stylus. The characters are afterwards rubbed over with charcoal, or some other black substance, which gives them the distinctness of an engraving. The same leaves are also used for umbrellas; and one of the licuala is said to be generally large enough to shelter six persons from the rain. Thunberg's Travels.

$\mp$ Of the palmetto there are two species; first, the chamcerops humilis (the dwarf palmetto), which gave rise to the name; the second is the palmetto royal, which will rise to 50,60 , or sometimes to 100 feet, which Linnseus calls chamgerops excelsa. 


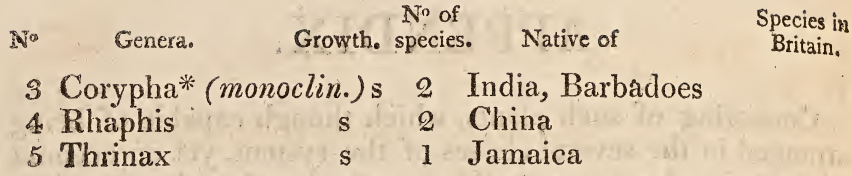

\section{2d. Feather-leaved, (Two houses.)}

\section{Drupa.}

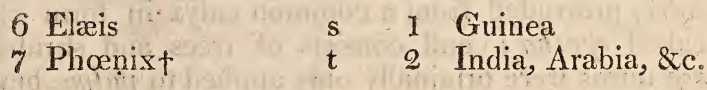

Feather-leaved, (one house.)

Drupa.

$\begin{array}{rlll}8 \text { Areca } & \text { t } & \text { I } & \text { India } \\ 9 \text { Cocos } & \text { t } & 3 & \text { Guinea, India } \\ 10 \text { Cycas } & \text { t } & 2 & \text { India } \\ 11 \text { Elate } & \text { t } & 1 & \text { India }\end{array}$

* The umbrella palm tree (corypha umbraculifera) it is said will grow about thirty-five years before it flowers, but as soon as that is over, it dies. The Plantain tree will sometimes be one hundred years before it flowers, but afterwards it: soon perisheth. The lavatera arborea will stand several winters, and grow to the size of a common pear tree, but when it hath once flowered, no art can prevent its perishing at the approach of winter.-See note to agave.

+ Phonix dactylifera (date or dactyl tree) is a very durable tree; but if it happens to be injured by some instrument so as to cause a decay, it is cut down at the root, and is then burnt on the spot; and its ashes are covered with a layer of earth, from the middle of which a new shoot soon arises, and becomes strong in a few years : as the Greek word for this palm is phicnix, it is probable that the fabulous history of the Arabian bird of that name reviving from its ashes, is founded on this circumstance.-(Travels ly the Able Mariti-printed in English, 1791). Which seems to have been an hierogliphic emblem of the destruction and resuscitation of all things. It is an observation that where date trees grow, water is always found seear. The fruit is an egg-shaped berry, inclosing a hard seed.

¥ The areca nut (areca catechu) is much used in the East for chewing along with the leaf of the betel.-(See betel.) In Bengal it is called sooparee.

$\S$ From the cocoa-nut tree (cocos nucifera), besides the great use made of the husk, the shell, the kernel, and the milky substance in the centre, is made the wine called palm wine; and an agreeable liquor is also extracted from the blossoms called toddy; which, after being fermented and distilled, is called rack, or arrack; which is said to be preferable to the rack made of rice or sugar.

1) Cycas circinalis, - see note to sago in Table of Vegetable Drugs. 
No of

Species in

No Geneta.

Growth. species. Native of

Britain.
12 Nipa
t 1 Amboyna
13 Zamia
t 5 Kafferland in Africa

3d. Twice feather-leaved, (one house.)

Drupa.

14. Caryota

s 1 India.

15 Licuala* (monoclin.) t 1 Amboyna, Ceylon

\section{From the Supplement.}

16 Mauritia

s 1 Surinam

17 Ginkgo

18 Arengat

$\begin{array}{lll}\text { t } & 1 & \text { Japan } \\ \mathrm{t} & 1 & \text { Moluccas }\end{array}$

* Licuala spinosa (the tallipot tree).--See note to borassus.

+ C. Labillardiere read a memoir (in the national institute of France, in 1801) on a new species of palm called arenga, from the word areng, a name given to it in the Moluccas. He calls it the arenga saccharifera. It rises about 60 feet (English); the alated leaves are 16 to 20 feet long, the leaflets are dentaled at their extremity, and have one or two appendices at their base. The leaf-stalks are large at their base, and furnished with long black threads, with which the Malays make very durable ropes and cables. The leaf-stalks serve to construct their habitations, and the leaves to cover the roof. A saccharine liquor is obtained from this palm, by making incisions; and by proper management the tree will produce this liquor more than half the year. By simple evaporation it gives a kind of sugar, of the colour and consistence of chocolate newly made, but which is capable of further refining. The nuts of the young fruits make good confectionary, and the pith of the trunk yields excellent sago. 
$\therefore 1$

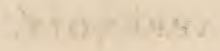

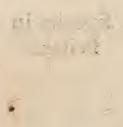

$$
\text { (15) }
$$

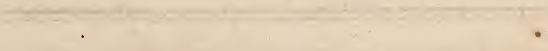

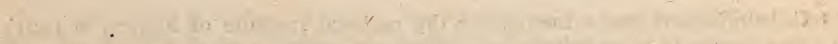

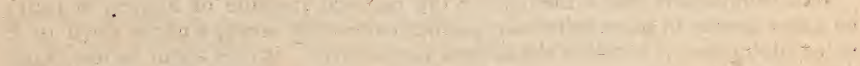

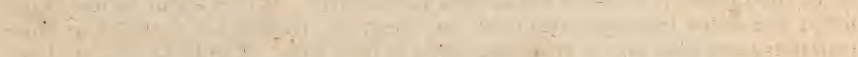

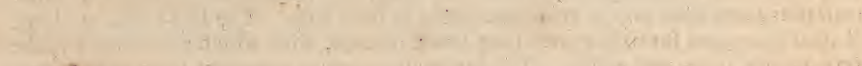

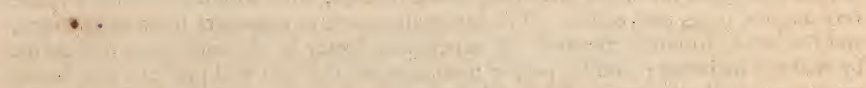

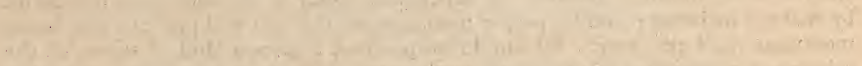

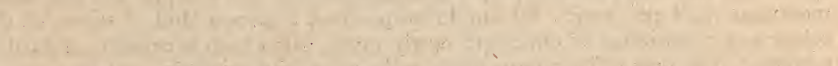

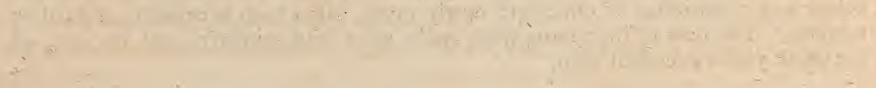




\section{INDEX OF THE GENERA.}

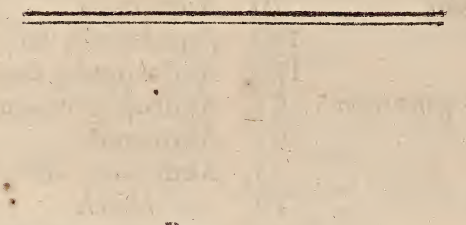

\begin{tabular}{|c|c|c|c|}
\hline & & & \\
\hline I.BR'OMA & 133 & Adiánthum, maiden hair & 171 \\
\hline brus, witd liquorice & 129 & Adónis, bird's eye & 10 \\
\hline cæ'na & 58 & Adóxa, tuberous mos & \\
\hline caly'pha & 156 & chatel & \\
\hline canthus, bear's breech & 110 & E'gilops, hard grass & 16 \\
\hline cer, maple & 166 & Egíphila & \\
\hline nin & 22 & ium, goutwort & \\
\hline a, milfoil, yarrow & 142 & Eg & 15 \\
\hline ipota & 77 & mene, false sen- & \\
\hline ies & 68 & plant & \\
\hline Virginiar & 161 & chesnit & \\
\hline c & 121 & hemlock & \\
\hline aconi & 104 & Agapánthus, African blue & \\
\hline eet rus & 80 & li & \\
\hline & 131 & $\mathrm{Ag}$ & 17 \\
\hline chum, $a c$ & 171 & Agáve, American aloe & \\
\hline , herb-christopher & 101 & Agératum, false hemp & \\
\hline dansónia, $\quad A E$ & & & \\
\hline sour gourd & 122 & ony & \\
\hline & 163 & mpion, o & \\
\hline & & & \\
\hline & & 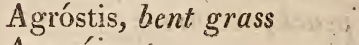 & \\
\hline & & & \\
\hline
\end{tabular}


A'ira, hair, grass

Aitónia

A'juga, bugle

A'izoon

Albúca

A'lcea, hollyhock

Page

Alchemíllá, lady's mantle 58

52 Anábasis, berry-bearing

120

108

98

79

123

Alchor'nea

Aldrovánda

120

Aléctra

Alétris, base aloe

110

Aléurites

A'lga, flags

Alísma, water plantain

17

Allamánda

Alliónia

A'llium, garlic

Allophy'llus

A'loe, aloe

61 Andrósace

55

78

83

Alopecúrus, fox-tail grass

Alpínia

Alsíne, chickweed

Alstónia

Anacardium, acajou, or

Page

70

cashere nut

86

Anacy'clus

Anagállis, pimpinel

Anagy'ris, stinking bean trefoil

Anastática, rose

icho 117

Anchúsá, bugloss

Ancístrum

Andráchne, base orpine 158

Alstroeméria

Althæa, marshmallow

51. Angúria

ry'ola,
thistle

90

Aly'ssum, madwort

73 Annóna, custard apple

167

Andry'ola, downy soze-

61

Amaránthus, amaranth

Amary'llis, lilly daffodil

100

78

123

117

Anemóne, wind flower

138

105

Angélica, angelica $7_{1}$

Angúria $\quad 152$

Amasónia

154. Antholiza, mad-flower

105

A'nthemis, chamamile 142

Anthéicum, spider-wort 79

Anthistíria

Anthóceros

173

77 Anthospérmum, amber

Ambrósia

112

Ambrosínia

154 tree

168

Amerímnon

131

Anthoxánthum, vernal

grass; yellow flower 48

Anthy'llis, kidney wetch,

Améllus, Cape star-flower 142

Amethystéa

47

Anticorus or wound-wort

Ammánnia

57 Antidésma

83

A'mmi, bishop's weed

71- Antirrhínum, snap dragon 111

Amómum, ginger

44. Apáctis

93

Amórpha, base indigo

Amy'gdalus, almond,

129

A'phanes, parsley-piert

59

Aphyllánthes

78

Amz'ris

97 Aphytéia

119

83. A'pium, parsley 
Aplúda

Apócynum, dog's bane Aponogéton

Aquártia

Aquílaria

Aquilégia, columbine

Aquilícia

A'rabis, base tower mustard

A'rachis, ground nut

Arália, berry-bearing angelica

A'rbutus, strawberry tree

A'retium, burdock

A'retopus, bear's paz

Arctótis

Ardísia

Arduína

Aréca

Arenária, sand-roort

Arenga

Arethúsa

Arétia

Argemóne, prickly poppy 102

Argophy'llum

Aristea

Aristída, oat grass

Aristolóchia, birth-wort

A'rnica, leopard's bane

Aróuna

Artédia

Artemísia, mugroort,wormwood, tarragon 140

Artocárpus, jaca-tree, or bread fruit

A'rum, walie robin; draArúndo, reed gons; \& fryer's cowl 150

A'scium

A'sarum, asarabacca

A'scarina

67

115

129

\section{4}

63

178

91

93

159
Page

167 Asclépias, swallow-wort

69 A'scyrum,St.Peter'swort;

82

55

120

104

90

139

168

144

65

179

147

51 A'tropa, deadly nightshade 63

St. Andrew's cross - 134 .

Aspálathus, African

broom; rose-wood 129

Aspáragus, usparagus

Asperúgo, small wild

$$
\text { bugloss }
$$

Aspérula, wood-roof

Asphódelus, asphodel $\quad 57$

Asplénium, spleen-wort 171

Assónia

121.

A'ster, aster, starwort 141

Astrágalus, liquorice or

$$
\text { milk vetch } 131 .
$$

Astrántia, black master-

wort

70

Astrónium

161

Athamánta, base spignel 71

Athanásia, African goldy locks

Athénæa

140

Atractylis, distaff thistle 139

Atrágene

Atrapháxis

105

80

167

149 Aublétia 106

14.1 A'ucuba 153

46 Avéna, oats 52

71 Avérrhoa 92

Avicéunia 111

Axy'ris $\quad 15 \%$

Ayénia 148

152 Aź́lea, American upright honeysuckle

B

102 Báccharis, plowman's

Bacópa 


\begin{tabular}{|c|c|c|c|}
\hline & Page & & Page \\
\hline Báctris & 154 & Bisérrula & 131 \\
\hline Bæckéa & 84 & Bíxa, anotto & 103 \\
\hline Brobótrys & 65 & Blackbúnia & 57 \\
\hline Balanóphora & 151 & Bládhia & 63 \\
\hline Ballóta, black horehound & 108 & Blæ'ría & 56 \\
\hline Baltimóra & 143 & Blakéa ly & 94 \\
\hline Banára & 94 & Blásia & 173 \\
\hline Banistéria & 91 & Bléchnum & 171 \\
\hline Bánksia & 57 & Blitum, blite & 45 \\
\hline Bárbula & 172 & Bobártia & 51 \\
\hline Barléria & 111 & Boccónia, celandine tree & 93 \\
\hline Barnadésia & 139 & Boehméria & 153 \\
\hline Bạringtónia & 122 & Boerháavia & 44 \\
\hline Bártsia & 111 & Bolétus & 176 \\
\hline Basélla, Malabar night- & & Bómbax, silk cotton tree. & 122 \\
\hline shade & 73. & Bonnétia & 101 \\
\hline Bássia & 94 & Bóntia, wild olive of Bar- & \\
\hline Bassóvia & 63 & badoes & 112 \\
\hline Bátis. & 161 & Borágo, borage & 60 \\
\hline Bauhinia, mountain ebony & 87 & Borássus, Malabar palm, & \\
\hline Befaria & 94 & or Palmira & 177 \\
\hline Begónia & 155 & Borbónia & 129 \\
\hline Béllis, daisy & 141 & Boséa, yerva mora, or & \\
\hline Béllium & 141 & golden rod tree & 70 \\
\hline Bellónia & 65 & Bossiæaa & 129 \\
\hline Bérberis, berbery & 77 & Brabéium, African al- & \\
\hline Bérgera* & 88 & mond & 167 \\
\hline Bérgia & 92 & Brasénia & 105 \\
\hline Bertiéra & 63 & Brássica, cabbage & 115 \\
\hline Besléria & 113 & Bráthys & 104 \\
\hline Béta, beet & 70 & Breynía & 167 \\
\hline Betónica, betony & 108 & Bríza, quake grass & 52 \\
\hline Bétula, birch-tree & 153 & Bromélia, ananas, or pine & \\
\hline Bídens, water hemp agri- & & apple & 76 \\
\hline mony & 140 & Brómus, broom grass & 52 \\
\hline npet flower & 111 & Brosímum, bread-nut & 160 \\
\hline Biscutélla, br & & Brossæáa & 61 \\
\hline tard & 117 & Browállia & 111 \\
\hline
\end{tabular}

* Bergera, an aromatic plant of Africa, is omitted in 8th edit. of Gen. Plant. 


Brownéa
Brucéa, woginioos
Brunélla, see Prunella
Brúnia
Brunsfélsia
Bryónia, white bryony
Bry'um, wall moss
Búbon, Macedonian
$\quad$ parsley
Buchnéra
Bucída
Buddléia
Buetéria
Bufónia, toad grass
Bulbocódium, spring
$\quad$ mountain saffron
Bumálda
Búnias, sea rocket
Búnium, pig nut, or earth
$\quad$ nut
Buphthálmum, forcign
ox-eye
Bupleúrum, hare's ear
Burmánnia
Burséra
Bútomus, flowering rush
Buxbáumia, horse-foot
Búxus, box
By'ssus

Page

121

161

Callígonum

Page

Browné

Callísia

103

Callítriche, star grass 4.5

67 Calodéndrum, fine-tree 66

63 Calophy'llum,calaba plumio1

158 Caltha, marsh marigold 105

173 Calycánthus, Virginian

$$
\text { all-spice } 99
$$

71 Calyptránthes $\quad 96$

11 Camáx 63

90 Cambógia 101

56 Caméllia, tussubakki, or

119 Japan rose 122

59 Camerária 63

Camocládia, maiden plum 50

78 Campanúla, bell flower 65

70 Camphorósma $\quad 58$

116 Canarma 77

Canárium $\quad 161$

71 Canélla 94

142 reed or cane 4.4

71 Cánnabis, hempr 161

76 Cápparis, caper bush $\quad 101$

76 Caprária 111

86 Cápsicum, Guinea pepper 63

173 Capúra 77

153 Cardamíne, lady's smack 116

173 Cardiospérmum, heartseed, or pea $\quad 85$

C

Carduus, thistle $\quad 139$

Cacália, Alpine colt's foot 140 Cárex, sedge, Cyperas

Cáchrys

71

Cáctus, melon thistle grass

153

96

Cæsalpínia, brasiletto

Caríca, papazo tree $\quad 163$

Cálamus, salack

87

Calceolária, slipper

64

80 Carlína, carline thistle 139

Caléa

Carolinéa

122

Caléndula, marigold $\quad 143$

Cálla, African arum 150

Caróxylon $\quad 67$

Carpésium

141

Carpínus, Tornbeam $\quad \mathbf{1 5 6}$

Callicárpa, Johnsonia 56

Carpdétus 14:46: 67 
Page

Carpobólus

Ceropégia

Cárthamus, base saffron 139

Cárum, carui, or caraway 72

Cary'ocar

104

Cary'ota,bipinnated palm 179

Caryophy'llus, clove tree 10]

Casearéa

Céstrum, base jasmine

Chærophyllum, wild cher-

Chálcas

Chamæ'rops, dwarf palm,

Casuarína or palmetto

Chamíra

Cássia, senna

152

Cassíne, cassio-berry bush 73

Cassy'ta

Castilléja

Chára

Chayóte

Cheiránthus, stock July

Catanánche, Candy lior's

$$
\text { foot }
$$

Catesbæa, lilly thorn

Catúrus

Caúcalis, base parsley

160

Ceanóthus, Nero Jersey

71

$$
\text { tea }
$$

Cecrópia

Cedréla, Barbadoes cedar 66

Cedróta

Celástrus, staff tree

Celósia, cockscomb ama-

Célsia

$$
\text { ranth }
$$

Céltís, nettle tree

68

Cénchrus

112

Centauréa, centaury

166

Centúnculus, chaff weed

Cephalánthus, butbton wood 55

Cephæ'lis flower

Chelidónium, celandine 110

Chelidónium, celandine 101

Chelóne

112

Chenoléa

Chenopódium, goose-foot 70

Cherléria

Chimárrhis

Chinodéndron

Chiocócca

Chionánthus, snowdrop

\section{tree}

Chirónia

Chlora, yellow-wort, or perfoliate centaury 84

Choetocárpus , $\quad 55$

Chomélia ' 56

167 Chondrílla, gum cichory 138

143 Chrysánthemum, corn

Cerástium, mouse-ear chickweed

Chry'sitrix

Chrysobálanus,cocoa plum 97

Chrysócoma, goldy locks 140

92 Chrysógonum, goll-joint 144

Ceratocárpus. $\quad 151$

Ceratónia, carob tree 168

Ceratophy'llum,horn-wort, or horn-leaf, pond weed 155

Cérbera

64

Cércis, Judas tree

Cerínthe, honey wort

64. Cícer, chick peas

Cícca

Chrysophy'llum,star-apple 64

Chrysosplénium, golden

$$
\text { saxifrage }
$$

87 Cichórium, cichory, or 60

endive 
Page

Page

Cicúta, water hemlock 72 Cólchicum, meadow safCienfuegósia $\quad 122$

Cimicifuga, Jug-bane $\quad 104$

Cinchóna bark tree . $\quad 65$

Cinerária, sky-flower $\quad 141$

Cínna

Ciponíma

120

Circæ'a, enchanter's nightshade

Cissámpelos

163

Cissus

Cistus, rock rose

Citharóxylon, fiddle rood 113

Cítrus, citron

133

Cláthrus

176

Clavária

176

Claydónia

173

Claytónia

66

Clématis, virgin's bower 105

Cléome, base mustard 116

Cleónia

109

Clerodéndrum

112

Cléthra

88

Cléyera

101

Clibádium

154

Cliffórtia

Clinopódium, field basil 109

Ciitória

132

Clúsia, balsam tree

167

Clútia

164

Clypéola, treakle mustard'117

Cneórum, widow wail

Cnícus

Coccóloba, sea-side grape 85

Cochleária, scuroy-grass, horse-radish

Cócos, coco nut fron

Coldénia

Collinsónia

Columnéa

Colútea, bladder senna 130

Cómarum, marsh cinque-

foil

Combrétum

Cométes

58

Commelína

Commersónia $\quad 74$

Comocládia 49

Conférva, crow-sike $\quad 174$

Coníum, hemlock $\quad 71$

Cónnarus 120

Conobéa 111

Conocárpus, button tree 67

Convallaria, lilly of the valley

Convólvulus, bindweed 61

Cony'za, greater fleabane 141

Copáifera,balsam capaivi tree

Coprósma

70

Córchorus, Jew's mallow 101 Córdia, sebesten

64

Coreópsis, tickseed sun-

flower 143

Coriándrum, coriander $\quad 72$

Coriária,myrtle-leaved sumach

Córis, heath low pine $\quad 61$

Corispérmum, tickseed 45

Cornucópiæ, horn of

117

Códia

178

Códon

85

Cofféa, coffee tree

Coíx, Job̆s tears

plenty

Córnus, dogwood, corne-

$$
\text { lian cherry }
$$

\section{Cornútia}

65 Coronílla, jointed podded 
$\begin{array}{rr}\text { Corrigíola } & \text { Page } \\ & 74\end{array}$

Cortúsa,bear's ear sanicle 61

Córylus, hazel, or nut tree 156

Cory'mbium

145

Corynocárpus

Cory'pha, mountain palm, coddapana, or cabbage tree

Cústus, wild ginger $\quad 44$

Cótula, May weéd 141

Cotylédon, nanel-wort 92

Coumaróura

128

Couroupíta

122

Crámbe, sea cabbage $\quad 116$

Craniolária

112

Craspédia

145

Cratæ'gus, hawthorn

Cratæ'va, garlic pear

93

Crássula, lessèr orpine $\quad 74$

Crépis, base hawliweed 138

Crescéntia, calabash tree 110

Créssa

Crínum, asphodel lilly

Críthmum, samphire

Crócus, saffron

Crossóstylis

Crotalária,

Cróton, base ricinus $\quad 156$

Crucianélla, petty madder 57

Crúdia

Cruzíta

90

Cry'psis

Cryptóstomum

48

Cucúbalus, berry-bearing:

Cucullária campion, or chickweed 91

Cúcumis, cucumber

Cucúrbita, gourd

158

Cumínum, cumin

158

Cuníla

72

Cunónia

Page

Cupréssus, cypress 157

Curatélla 103

Curcúma, turmeric $\quad 44$

Curtisía $\quad 57$

Cuscúta, dodder $\quad 59$

Cussónia $\quad 73$

Cyanélla $\quad 79$

Cyathús $\quad 176$

Cy'cas, todda panna $\quad 178$

Cy'clamen, sow bread 61

Cy'clas 90

Cylísta $\quad 129$

Cymbária 113

Cynánchum, base dog's bane 69

Cy'nara, artichoke $\quad 139$

Cynoglóssum, hound's tongue 60

Cynométra $\quad 88$

Cynomórium, the Maltese fungus 152

Cynosúus, dog's tail grass 53

Cypérus, greater galangal 50

Cypripédium, lady's slip-

$\begin{array}{ll}\text { per } & 147\end{array}$

Cyrílla 68

Cyrtánthus $\quad 77$

Cy'tinus $\quad 150$

Cy'tisus, trefoil tree

D

Dáctylis, cock's foot grass 50

Dáis 90

Dalbérgia $\quad 128$

Dalechámpia $\quad 156$

Danáa 70

Datísca, base hemp 163

Dáphne, mezerion, spurgelaurel 84

Datúra, thorn apple 61 
204:- Page Page

Dácus, carrot 71 Dracæ'na 79

Decumária

94. Dracocéphalum, dragan's

Degúelia

131 head

109

Delíma

103

Delphínium, larkspur $\quad 104$

Dracóntium, dragons $\quad 150$

Deutzía

91

Drócera, sundezo

75

Dentária, toothwort

Dryándra

120

Diálium

116 Dry'as

99

Dianthéra

48

Dry'pis

74

47

Diánthus, pink

Duránta

113

Diapénsia

Dicéra

101

Dichóndra

Dúrio, durion

134

Duróia

Dictámnus, fraxinella

Dicránium

87 E'benus, ebony of Crete 129

Digitális, fox-glove

172. Echinóphora, prickly

Dilátris

Dillénia

112

Diódia

Diona'a, Tenus's fly-trap

Dioscorén, Indian yam 162

Echínops, globe thistle 144.

Diósma, African spirca 66

Diospy'ros, Indian date plum, or medlar of Louisiana

Diphy'sa

Echítes

E'chium, viper's bugloss 60

Eclípta

142

Ehretia

64

Ehrhárta

Ekebérgia

88

Elixagnus, wild olive 58

Dípsacus, teazel

Elæocárpus

102

Elæ'is

178

Elaphríum

83

Dirca, leather rood

84. E'late

178

Dísa

147 Elatérium

151

Disándra

Elátine, water wort

Dodártia

112

Elæodéndron

Dódecas

94

Dodecátheon, meadia

Elephántopus, elephant's

Dodonæ'a

Dólichos, cow-itch

Dombéya foot

144

Ellísia

64

130 E'lymus, lime grass $\quad 53$

Doræ'na

Embélia

62 Embóthrium 58

Dorónicum, leopard's bane

E'mpetrum, berry-bearing

Dorsténia, contrayerva heath, or crow berries 160 
Page

E'phedra, shrubby horse tail sho 164

Ephiélis

Epidéndrum, vanelloe $\quad 147$

Epigæ'a, trailing arbutus 90

Epilóbium, willow herb 83

Epimédium, barren wort 57

Equisétum, horse tail $\quad 170$

Erán themum, earth flower 46

Eríca, heath

83

Erígeron, lesser fleabane 141

Erínus

112

Eriocáulon, wool stalk

53

Eriocéphalus , 144

Erióphorum, cotton grass 50

Erithalis

65

Eirnodéa

55

Eródium, heron's bill 119

Ervum, bitter vetch 132

Ery'ngium, eryngo, or sea

$$
\text { holly }
$$

Erythrína, coral tree

Erythrónium, dog's tooth

- violet

Erythróxylon

Ery'simum, hedge mustard

Escallonia

Ethúlia

Eucléa

Eugénia

Evólvulus

Euónymus, spindle tree

Eupatórium, hemp agrimony

67 Fúngi, fungusses

F

Fabrícia

97

Fagára

57

Fagónia

88

Fagræa 64

Fágus, beech, chesnut $\quad 155$

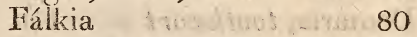

Ferrária, Cape narcissus 148

Férula, giant fennel $\quad 72$

Festúca, fescue $\quad 52$

Fevíllea 162

Fícus, fig

Filago, cotton, or cud

143

Fílices, ferns $\quad 170$

Fisidéns 173

Flacourtía $\quad 163$

Flagellária 81

Tlabellária 121

Fontinális, water moss $\quad 173$

Forskohléa 92

Fórstera 147

Fothergilla $\quad 104$

Fragária, strawherry $\quad 99$

Frankénia, sea heath 77

Franklínia $\quad 122$

Fráxinus, ash tree $\quad 168$

Fritillária, fritillary $\quad 79$

Fúcus, wrack, or sea weed 175

Fuiréna

50

Fumária, fumuterra $\quad 128$

Euphórbia, spurge

140

Euphrísia

Eury'a

94

Eury'andra

104

E'xacum

56

Excocária, aloes wood 160

Gaillárdia

142

Gáhnia $\quad 80$

Galánthus, snowdrop $\quad 77$

Gálax

Galáxia

Galéga, goat's rue

132 
$\begin{array}{lr}\text { Galénia, Cape jasmine } & \text { Page } \\ \text { Galeópsis, hedge nettle } & 108 \\ \text { Gálium, cheese rennet } & 57 \\ \text { Galopína } & 59 \\ \text { Garcínia, mangostan } & 99 \\ \text { Gardénia, Cape jasmine } & 66 \\ \text { Garidélla, fennel flower of } \\ \text { Crete. }\end{array}$

Gaulthéria, Canadianvine 90

Gáura, yellow Virginian

$$
\text { loose-strife }
$$

Genióstoma

Génipa

Genísta, single-seeded broom

Gentiána, gentian

Geoffróya, cabbage-bark tree.

Geránium, crane's bill 121

Gerárdia

Geropógon

Gesnéria

Gethy'llis

Géum, avens, or herb bennet 99

Gínkgo, maiden-hair tree 179

Ginóra

Gisékia

Glabrária

Gladíolus, corn flag

Glaúx, sea milkwort

Glecóma, gill, or ground ivy

Gleditsía, three-thorned acacia

Glínus

Glóbba

Globulária, blue globe daisy

Gloriósa, superb lily

Glochídion

Glossopétalum
83

62

66

112

138

112

78

79

79 Hæmánthus, blood flower 77

152 Hæmatóxylon, logrood 88 74. Halésia, snowdrop tree 94.

Gomózia 59

Gomphréna, globe amaranth

70

Gonocárpus 58

Gordónia, loblolly bay 122

Gortéria 143

Gossy'pium, cotton $\quad 122$

Gouánia $\quad 166$

Gratíola, hedge hyssop $\quad 47$

Gréwia

Grías

150

Gríelum " 92

Grímmia , 179

Grisléa $\quad 83$

Griselínia $\quad 166$

Gronóvia 68

Gúajacum, lignum vita, or pockwood 88

Guaréa

83

155

Guilandína, nickar tree 88

Gundélia

Gúnnera

144

147

Gustávia $\quad 122$

Gynopógon 64

Gypsóphila $\quad 91$

$\mathrm{H}$
Gloxínia 111

Glúta 148

Gly'cine, scarlet kidneypea 132

Glycyrrhíza, liquorice 131

Gmelína

Gnaphálium, tree everlasting, cudreed $\quad 141$

Gnétum $\quad 157$

Gnídia 84

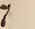




\begin{tabular}{|c|c|c|c|}
\hline & Page & & page \\
\hline Halléria, American fly & & Hibíscus, althaa frutex & \\
\hline honeysuckle & & Hieracium, hawkreed & \\
\hline alóragis & 85 & Hillia & 77 \\
\hline amélis, witch hazel & 59 & Hiræ'a & \\
\hline céllia & 66 & Hirtélla & \\
\hline & 57 & $\mathrm{Hi}$ & \\
\hline $\begin{array}{l}\text { iaselquistra } \\
\text { lebenstrétia }\end{array}$ & 110 & Hippocrépis, horse-shoe & \\
\hline lédera, ivy & 68 & 10 P & \\
\hline edwígia & 83 & Hippómane, ma & \\
\hline Iedy'crea & 68 & Hipl & 210 \\
\hline Iedycárya & 163 & mare's tail & \\
\hline Hedyótis & 56 & Hoffin & \\
\hline Hedy'sarum, French ho- & & Hólcus, Indian millet & \\
\hline neysuck & 131 & Holósteum & \\
\hline eistéria & 88 & & 10 \\
\hline hus, sur & 143 & $\mathrm{H}$ & 134 \\
\hline Ieliotrópium, turnsol & 60 & Hórdeum, barley & 53 \\
\hline Heliocárpus, sun fruit & 95 & Hormínum, Pyranean & \\
\hline Helicónia & 68 & $y$ & 109 \\
\hline éres, skrew tree & 149 & ilfoil & \\
\hline nium, base sun-flower & 141 & H & \\
\hline & 116 & & \\
\hline orus, hellebore & 105 & a & 10 \\
\hline as & 80 & $a$ & 93 \\
\hline a. & 176 & $\mathrm{H}$ & 121 \\
\hline cállis, day lilly & 79 & Hí & 16 \\
\hline is & 111 & & 157 \\
\hline is, $m \imath$ & 171 & th & 79 \\
\hline $\mathrm{He}_{1}$ & 76 & & 1 \\
\hline Heracléum, cow parsnip & 71 & $\mathrm{H}$ & 176 \\
\hline Hermánnia, African & & Hy & \\
\hline marsh mallow & 120 & & \\
\hline eritiéra, looking-glass & & Hydrócharis, frog's bit & 16 \\
\hline plant & 156 & Hydrocótyle, water navel & \\
\hline érmas & 167 & & 71 \\
\hline ernándia, & 153 & $\mathrm{H}$ & \\
\hline$r t$ & 70 & Hyd & 55 \\
\hline & 116 & $\mathrm{Hyc}$ & \\
\hline sa- & & a, locust tree & \\
\hline & 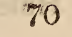 & che & \\
\hline
\end{tabular}


Page Page

Myoscy'amus, henbane 62 Isopy'rum 105

Hyóseris, yellow eye. $\quad 138$ I'tea 66

Hypécoum 59 I'va,falsejesuit's barktree 154

Hypéricum, St. John's I'vira 129 wort 134. Júglans, walnut $\quad 156$

Hy'pelate

84 Júncus, rush $\quad 80$

Hy'pnum

Hy'ptis

Hypocharis

Hypóxis

173 Jungermánnia

173

108 Júngia 144

138 Juníperus, juniper $\quad 164$

Hyssópus, hyssop

Jussiéua

88

108 Justítia

I'xia

Jacqúinia

I'xora, Indian wild jas-

64 mine

Jambolífera

Játropha,manihot, cassada 157

Jasióne, scabious with. rampisn heads, or sheep scabious

Jásminum, jasmine

Ibéris, candy tuft, sciatica cress

Jeffersónia

Ignátia

I'lex, holly

Illécebrum, mountain knot grass
Illicium

Impátiens, balsam

59

Imperatória, master wort

Indigófera, indigo

Inocárpus

I'nula, elecampane.

Joncoquétia

Ipomóea, quamoclit

Irésine

I'ris, flower de luce

Isátis, woad

Ischo'mum

Isnárdia

Isóetes

92 Lachnæ'a

I.

Kampféria, round zedoary 44

Kálmia, dwarf laurel of

Kéura America

Kiggelária

Kleinhóvia

Kleínia

Knáutia

Knóxia

Koelréutera

Koenígia

Kram'eria

Kúhnia

Kyllíngia

62. Lacistéma

55

Labátia

104

162 Lachenália

84

49 Lactúca, lettuce $\quad 1.98$

116 L'x'tia 103

167 Lagerstræ'mia $10 \%$

58 Lag'œcia, wild or base

171 cumin 


\begin{tabular}{|c|c|c|}
\hline & Page & Pags \\
\hline Lagúna & 123 & Lílium, lily \\
\hline Lagúrus, hare's tail grass & 51 & Liméum \\
\hline Lámium, dead nettle & 108 & Limodórum,base hellebore 147 \\
\hline Lanária & 78 & Limónia, madja \\
\hline Lantána, viburnum of & & Limosélla, mudwort \\
\hline America & 111 & Lincónia \\
\hline Lappágo . & 53 & Lindéra \\
\hline Lápsana, nipplewort & 139 & Lindérnia \\
\hline Laserpítium, laserwort & 71 & Linnæ'a \\
\hline Lasióstoma & 56 & Línum, flax \\
\hline Lathræ'a & 110 & Lipária \\
\hline Lathy'rus, chickling vetch & 130 & Líppia \\
\hline ula, lavender & 108 & Liquidámber, sweet gum 355 \\
\hline ra, mallow tree & 123 & Liriodéndron, tulip, or \\
\hline ́ria & 64. & lily tree \\
\hline Láurus, bay-tree & 86 & Lisiánthus \\
\hline Lawsónia,Egyptian privet & 83 & Lithospérmum, gromwel 6 \\
\hline Lec & 54 & Littorélla \\
\hline Lécythis & 102 & Lobélia, cardinal flower 145 \\
\hline Lédum, marsh rosmary, & & Loecélia \\
\hline or cistus & 88 & Loeflíngia \\
\hline Leéa & 154 & Loliúm, darnel \\
\hline Leersía & 173 & Lonchítis, rough spleen- \\
\hline ótis & 100 & Toniort \\
\hline a, duck-meat & 152 & Lonicéra, honeysuckle \\
\hline iscia & 102 & Loósa \\
\hline ice, lion's leaf. & 77 & Loránthus, lea \\
\hline lion & 139 & Lótus, bird's foot trefoil 132 \\
\hline s, lion & 108 & éa \\
\hline ium, dittander & 117 & rígia \\
\hline Lé1 & 174 & , moonwort \\
\hline permum & 97 & s, lupine \\
\hline Lerchéa & 119 & , campion \\
\hline Leucójum, greater snow- & & Ly'cium, boxthorn \\
\hline & 78 & Lycopérdon, fuz, or puff- \\
\hline yséra & 142 & ball \\
\hline a, liverz & 174 & Lycopódium, roolf's foot \\
\hline la, tallipot tree & 179 & moss \\
\hline Lightfoútia & 64 & Lycópsis,sm \\
\hline $\begin{array}{l}\text { Ligústicum, lovage } \\
\text { Ligústrum, privet }\end{array}$ & $\begin{array}{l}72 \\
46\end{array}$ & $\begin{array}{l}\text { Ly'copus, water horehound, } \\
\text { wolf's foot }\end{array}$ \\
\hline
\end{tabular}


Page

Lygéum, hooded matweed 50 Lysimáchia, loosestrife 62 Ly'thrum, willow herb $\quad 94$.

M

Mába

Maçrocnéum

Macrolóbrum

Mahérnia

Malachodéndrum

Málachra

Málope, base mallow

Malpíghia, Barbadoes

$$
\text { cherry }
$$

Málva, mallow

Malvavíscus

Mamméa, mammee

Mangífera, mango tree

Magnólia, laurel-leaved

$$
\text { tulip tree. }
$$

Manisúris

Mannéttia

Manúlea

Maránta, Indian arrow root

Marcgrávia

Marchántia

Margaritára

Maríca

Marrúbium, horehound

Marsiléa

Marty'nia

Massónia

Matouréa

Matricária, feverfuge

Matthíola

Maurítia

Mebórea

Medéola, climbing African asparagus

Medicágo, snail trefoil

123

123

112
Meesía

Page

Melaléuca

172

134

Melampódium, black-foot 144

Melampy'rum, cow wheat 111

Melánthium, black flower 81

160 Melástoma, American

65 gooseberry 89

49 Mélia, bead tree

75 Meliánthus, koney flower 113

123 Mélica, melic,or ropegrass 5\%

Melicócca

84

Melicópe

84

Melicy'tus

154

Melíssa, balm

109

Melíttis, base balm $\quad 109$

Melóchia

120

Melódinus

68

67 Melóthria, small creeping cucumber

106 Memécylon

167 Menáis

56 Menispérmum,moon-seed, Indian berry

Méntha, mint

49

84

64

Meg

100 Menyánthes, bogbane $\quad 62$

174. Mercuriális, mercury 163

162 Mesembryánthemum, $f \mathrm{~g}$

49 murigold 98

108 Méspilus, medlar 98

171 Messerschimídia 60

112 Mésua, Indian rose ches-

79 nut 123

110 Metrosidéros 97

142 Michélia, champacca $\quad 106$

66 Michaúxia 83

179 Micrópus, base cudweed 143

54. Micrótea 70

Mílium, millet $\quad 51$

80 Milléria $\quad 143$

131 Millingtónia 113 


\begin{tabular}{|c|c|c|c|}
\hline \multirow{3}{*}{$\begin{array}{l}\text { Mimósa, sensitive plant; } \\
\text { acacia }\end{array}$} & Page & & Page \\
\hline & & Murráya, Chinese box & 89 \\
\hline & 166 & Músa, plantain tree & 165 \\
\hline Mímulus, base foxglove & 112 & Músci, mośses & 171 \\
\hline limúsops & 84 & Mussæénda & 66 \\
\hline Minuártia & 54 & Mutísia & 142 \\
\hline Mirábilis, marvel of Peru & 60 & Myágrum, gold of pleasure & $e 117$ \\
\hline Mitchélla & 56 & Mygínda & 59 \\
\hline litélla, base American & & Myopórum & 111 \\
\hline sanicle; roucou & 91 & Myosótis, mouse-ear scor- & \\
\hline Inásium & 76 & pion grass & 61 \\
\hline Iníarum. & 45 & Myosúrus, mouse-tail & 75 \\
\hline $\begin{array}{l}\text { Mohríngia, mountain } \\
\text { chickweed }\end{array}$ & 85 & $\begin{array}{l}\text { Myríca, candle-berry myr } \\
\text { tle, gale, sweet willowe }\end{array}$ & \\
\hline Iníum & 172 & Myriophy!lum water mil & \\
\hline Molína & 121 & foil & 155 \\
\hline $\begin{array}{l}\text { Mollúgo, African chick- } \\
\text { weed }\end{array}$ & 54 & $\begin{array}{l}\text { Myrística, nutmeg tree } \\
\text { Myrmécia }\end{array}$ & $\begin{array}{r}152 \\
56\end{array}$ \\
\hline Ioluccélla, Molucca & & Myródia & 123 \\
\hline balm & 109 & ma, perfume-odour & 44 \\
\hline $\begin{array}{l}\text { Momórdica, male balsam } \\
\text { apple }\end{array}$ & 158 & $\begin{array}{l}\text { xylon, perfume-wood } \\
\text { ne, African box }\end{array}$ & \\
\hline Ionárda, Oswego tea & 47 & myrtle & 97 \\
\hline Cóti & 57 & déndrum & 102 \\
\hline iééria & 128 & Myrospérmum & 89 \\
\hline a, sïmplicity & 89 & & \\
\hline Monsónia & 133 & $\mathbb{N}$ & \\
\hline Móntia, small water chick- & 54 & Næmáspora & 176 \\
\hline ontíni. & 161 & Nán & 70 \\
\hline a & 112 & Nándina & 77 \\
\hline 'a & 49 & $\mathrm{~N}$ & 164 \\
\hline 1 & 48 & ssus, daffodil & 78 \\
\hline nda & 66 & $\mathrm{~s}$, mat grass & 50 \\
\hline Morisónia & 123 & Naucléa & 67 \\
\hline Mórus, mulberry tree & 154 & Néckera & 172 \\
\hline Moutouchía & 129 & Néctris & 80 \\
\hline$l d$ & 176 & Nepénthes, bandura & 148 \\
\hline Muhlenbérgia & 51 & nep, or catmint & 109 \\
\hline Mulléra & 130 & Nephélium & 154 \\
\hline hháusia & 134 & Nérium, oleand & \\
\hline gia & 102 & & 63 \\
\hline
\end{tabular}


Page

Wértera

50

Neuráda

Nicándra

Nicotiána, tobacco

92

O'rchis, orchis

Page

Nigélla, fennel flower

148

00 Origanum roild marjoram 109

62 Orixa 57

$6 \%$

Nigrína

104 Ornithógalum, star of

58

Nípa

179

Nissólia

130

Nitrária

Nolána

Nyctánthes, Arabian jasmine Bethlehem

Orníthopus, bird's foot 132

Orobánche, broom rape 110

61 Oróntium, floating arum 80

Ortégia

50

Ory'za, rice $\quad 80$

Nymphr'a, water lily 103

Ny'ssa, tupelo tree

167

0

Obolária

O'chna

Ochróma

Osbéckia

80

Osmítes

Osmúnda, osmund royal, or flowering fern $1 \%$

110 Osteospérmum, hurd-seed-

102 ed chrysanthemum 143

119 Osy'ris, poet's cassia 160

Ocotéa

O'cymum, basil

134

109

Oedéra

145

Oenánthe, water alropwort 71

Oenothéra, tree primrose

Olax

Othéra

Othónna, African rag-

wort

143

Oviéda

113

O'xalis, wood sorrel 92

50 Oxybáthus 49

O'lea, olive

Oldenlándia

46

Oly'ra

56

Omphaléa

153

153

Onocléa

Onónis, rest harrow

170

Onopórdon, woolly, or cotton thistle.

Onósma, ass-scent

Operculária

Ophioglóssum, adder's tongue

Ophiorhíza

55 Pancrátium, sea daffodil 78

Pandánus, Nicobar bread-

170

Ophióxylum, snake-wood 166

Ophíra

Ophyrs, twy hlade

Pachíra

123

Pædéria 64

Pæderóta, youth's delight 47

Pæónia, pæony

Paláva

104

123

Pallásia 95

Pánax, ginseng _ 168

fruit 160

Pánicum, panic grass 51

Papáver, poppy 101

Parietária, pellitory $\quad 167$

147 Páris, true-love

85 


\begin{tabular}{|c|c|c|c|}
\hline & Page & 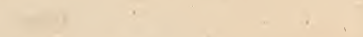 & Page \\
\hline Parivóa & 131 & Pharnacéum & 73 \\
\hline Parkinsónia & 88 & Phárus & 155 \\
\hline Panássia, grass of Par- & & Pháscum & 173 \\
\hline nassus & 74 & Phaséolus, kidney bean & 130 \\
\hline Parthénium, base fever- & & Phellándrium & 72 \\
\hline & 154 & Phelypæ'a & 160 \\
\hline áspalum, & 51 & Philadélphus, mock orange & e 97 \\
\hline Passerína, sparrow wort & 84 & Philly'rea, mock privet & 46 \\
\hline Passiflóra, passion flower & 149 & Phleum, cat's-tail grass & 31 \\
\hline Pastináca, parsnep & 73 & Phlómis, Jerusalem sage & 109 \\
\hline atagónula & 62 & Phlóx, lychnidea & 62 \\
\hline avétta & 56 & aix, dat & 178 \\
\hline ónia & 123 & Phórmium, New zealand & \\
\hline Paullínia & 85 & flax & 78 \\
\hline Péctis & 142 & Phry'ma & 109 \\
\hline Pedálium & 112 & Phyllánthus, sea-side lau- & \\
\hline edicularis, lousewort & 112 & & 153 \\
\hline vild Syrian rue & e 94 & Phy & .68 \\
\hline Pelargónium, stork's bill & 120 & hne & 152 \\
\hline ria & $11 \%$ & base hare's car & 71 \\
\hline 1'a & 56 & $\mathrm{Pl}$ & 78 \\
\hline tia & 166 & herry & 64 \\
\hline tápedes & 121 & a, rampions & 65 \\
\hline rum & 92 & Phytolacca, & \\
\hline Péntsemon & 112 & nightshade, or pork- & \\
\hline éplis, water purslain & 80 & weed & 92 \\
\hline rdícium & 141 & Pícris, ox-tongue & 139 \\
\hline ergulária & & Pilulária, pepper grass, or & \\
\hline Perilla & 109 & $l$ moss & 171 \\
\hline eríploca, Virginian silk & 69 & Pimpinélla, burnet saxi- & \\
\hline rótis & 52 & & 73 \\
\hline $\mathrm{ma}$ & 89 & er wort & 47 \\
\hline etésia & 56 & ine tree & 157 \\
\hline tivéria, Guinea henweed & d 81 & pepper & 48 \\
\hline tréa & 112 & Piripéa & 111 \\
\hline etrocary'a & 82 & Piscídia, fish-bane, or dog- & \\
\hline ucédanum, hog' & $l 71$ & od tree & 130 \\
\hline & 176 & fing & 68 \\
\hline & 131 & pist & 62 \\
\hline ss & 51 & water houseleek & 149 \\
\hline & & & \\
\hline
\end{tabular}


Page Page

Plagiánthus $\quad 121$ Portulacária 68

Plantágo,plantain $\quad 56$ Potamogéton, pond weed 59

Plátanus, plane tree $\quad 156$ Potentílla, cinquefoil 99

Platylóbium, flat pea 130 Potérium, garden burnet 15.5

Plectrónia 68 Póthos 150

Plínia

97 Prásium, shrubby hedge

Plocáma

Plukenétia

Plumbágo, lead wort

157 Prémna

109

60 Prenánthes, wild lettuce 139

Pluméria, red jusmine

63 Prímula, primrose 62

Póa, meadow grass

52 Prínos, winter-berry

77

Podophy'llum, ducle's foot 103

Próckia

103

Pohlia

172

Proserpináca

54

Poinciána, flower fence 88

Polemónium, Greek valerian

Poliánthes, tube rose

Prosópis

89

Protéa, silver trec $\quad 55$

62 Prunélla, self-head $\quad 109$

Póllia

Prúnus, plum tree.

97

Póllichia

Psídium, guava

97

Polycárpon, much-fruit

Polycnémum

Psorália, wart wort $\quad 131$

Poly'gala, milk wort

Psychótria, ipecacuania 66

Poly'gonum, knot grass

Ptélea, shirub trefoil

57

Poly'mnia

Ptéris, bracken, or brakes 171

Polypódium, fern, or polypody

Polyprémum, Carolina flax

Pterocárpus, Brasil wood 130

Pterónia

140

Púccinia

176

$1 \% 1$ Pulmonária, lung wort 61

Púnica, ponegranate $\quad 97$

56 Py'rola, winter green $\quad 89$

Polytríchum,golden maiden hair

Pómetia

Pommeréulla

Ponǽa

Pontedéria

Pópulus, poplar

Porána

Porélla

Porónia

Portésia

173

Portlándia

Portuláca, purslain

Py'rus, pear and apple tree 98

$\begin{array}{lr}\text { Quália } & \\ \text { Quararibéa } & 44 \\ \text { Qúassia } & 120 \\ \text { Quercus, oak } & 89 \\ \text { Quéria } & 155 \\ \text { Quisqualis } & 54 \\ \text { Quivísia } & 89 \\ & 120 \\ \text { Radermáchia } & \\ \text { Rajánia } & 152 \\ & 162\end{array}$


Rándia, American boxthorn

Rochefórtia

64. Roélla

Ranúnculus, crorefoot $\quad 106$

Rohría

Raphanus, radish

Rondelétia

Rauvólfia

Rorídula

Reaumúria

104. Rósa, rose

Reichélia

73 Rosmarínus; rosinary

Renéálmia

44. Rótala

Reséda, base rockel, \&c.

Réstio

Rétzia

95

Rottboéllia

160 Royéna, African bladder

63

Rhacóma

57 Rúbia, maidder

Rhámnus, buckethorn

Rháphis

67 Rúbus, raspberry

Rhéedia

Rhéum, rhubarb

Rhéxia.

Rhinánthus, elephant's head

Rhodióla, rose-root

178 Rudbéckia, dwarf sun-

Ruéllia, American snap-

84

Ruizía

Rúmex, dock

Rhodóra

Rhizóphora, kandel of the Indians, mangrove, or mangles

Rhododéndron, dwarf rose bay

Rhopála

162 Rúmphia

Rúppia, sea gráss

Rúscus, knee holly

Russélia*

94. Rúta, rue

112

123

Ruyschía

Rhús, Sumach poison tree

Ríbes, currant and gooseberry

Ríccia, marsh liverwort

Richárdia

74.

Sáccharum, sugar cane

51

Sagína, pearl-wort $\quad 59$

68 Sagittária, arrow head 156

174. Salácia

Rícinus, palma christi

Ricótia

Ríttera

77 Salicórnia, salt-horns, or

Rivína

157

116 jointed glasswort

Sálix, willow

44

100

Sálmasia 160

58 Salsóla, glasswort

Robínia, false acacia 132 Salvadóra

* Russelia and vahlia are described by Mr. Murray, in his Systema Vegetalilium, as different plants; but Mr. Dryander assures us they are in reality the same. 
Page Page

Salvia, sage, clary

47 Scírpus, rush grass

Sámara

57 Sciúrus

Sambúcus, alder

Sámolus, round-leaved

Samy'da water pimpinel

73 Scleránthus, German linot

Sandóricum

65 Scléria grass

90 Sclerocárpus 143

Sanguinária, pucoon

121 Scólymus, golden thistle

103 Scopária

Sanguisórba, greater wild burnet

Scopólia

Scorpiúus, caterpillars 132

Sanícula, sanicle

Sántalum, saunders

Santolína, lavender cotton 140

Sapíndus, soap-berry

Sápium

85

Scorzonéra, viper's grass 139

Serophulâria, fig-wort 112

Scutellária, skull-cap 110

Saponária, soap-rvort

152 Securidáca, hatchet vetch 128

Saráca

91

Saróthra, base gentian

Sarracénia, side-saddle

$$
\text { flower }
$$

Saturéja, savory

Saty'rium, lizard flower

Saururus, lizard's tail

Sauvagésia

Saxífraga, saxifrage

Scabiósa, scabious

Scabríta

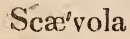

Scándix, Venus's comb, or shepherd's needle

Scheuchzéria, lesser flowering rush

Schínus, Peruvian mas-

$$
\text { tich }
$$

Schmiedélia

Schœ'nus, rush grass

Schrebéra

Schwálbia

Schwenkféldia

Schwénkia

Scílla, sqill

Sédum, lesser houseleek;

Seguiéria,

orpine; or stone crop 92

Selágo

103

102 Selínum, milk parsley 72

109 Semecárpus, ink-tree $\quad 74$.

148 Sempervívum, houseleek 95

82 Senécio, groundsel 142

66 Séptas 82

91 Serápias, helleborine 148

55 Serpícula 154.

56 Seríola 138

66 Seríphium 145

Serrátula, saw-wort $\quad 139$

72 Sesámum, vily grain 112

Séseli, hart-zoort of Mar-

81 seilles 79

Sesúvium

98

163 Sháwia

145

85 Sheffiéldia 63

50 Sheffléra 75

68 Sherárdia, little field mad-

111 der 57

64. Sibbáldia 75

47 Sibthórpia, base money-

79 roort 112

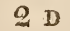

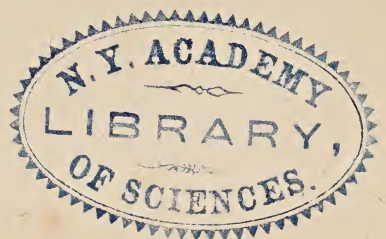


Page

Sícyos, single-seeded cucumber

Spæránthus, globe flower 144

Sída, Indian mallow

123

Spha'ria

176

Sphágnum, bog moss

172

Siderítis, iron-wort tree 109

Siderodéndrum

Spigélia, worm grass

Spilánthus

Sideróxylon, iron wood

Sigesbéckia

64. Spinácia, spinach

162

142. Spínifex 167

Siléne, catchfly

Spiræ'a

98

Sílphium, base chrysanthemum

Sinápis, mustard

Spláchnum, bottle moss 173

spondias, Brasilian plum 92

Siphonánthus

Sírium

116

Stáchys, base horehound 109

Síson, base stone parsley

Stæhelína

14.0

Síum, water parsnep

58

72

Sisy'mbrium, water cresses 116

Stapélia, A frican swallowwort, or cock's-comb fritillary

Staphyléa, bladder nut 74

Sisyrínchium,bermudiana 148

Skímmia

Skínnera

Stáavia

Státice, thrift

Sloanea, apeiba of the Brasilians, sappodillo 102

Smílax, rough bindweed 162

Smithía

132

Siny'rnium, Alexanders 79

Solándra

123

Solánum, nightshade

Soldanélla, soldanel

Solidágo, golden rod

64

63

142

Sónchus, sow thistle

139

Sonnerátia

97

Sophóra

Sórbus, service tree

88

98

\section{8}

Stellária, great chickweed 91

Stelléra, German groundsel, or gromwel.

Stemódia

Stemónitis

Stœ'be, base Athiopian elichrysum

Stephánium

144

Sterć́lia, dung wood

Sterculia, dung wood 157

Sterbeckia 102

Stéris

68

Stewártia

123

Stilágo, Chinese laurel 148

Stílbe

168

Sowérbia

153

Spargánium, bur reed

Stillíngia

157

Sparmánnia

Stípa, feather grass

101 Stratiótes, water aloe 105

Spanánthe

71

Strelítzia

50 Strigília

66

Spártina

130

Strumpfia

121

Spártium, broom .

74. Struthíola

Spathélia

92 Stylosánthes

Spergúla, spurry

57 Stry'chnos 
Sty'rax, storax tree

Subulária, awl-zort

Suriána

Swértia, marsh gentian

Swieténia, mahogany

Syéna

Symphónia

Sy'mphytum, comphry

Sy'mplocos

Syrínga; lilac

T

Tabernæmontána

Tácca

Tagétes, African marigold

Taligália

Tamaríndus, tamarind tree 50

Támarix, tamarisk

Támus, black bryony

Tanacétum, tansey

Tapúra

Tarálea

Tarconánthus, shrubby African flea-bane

Targiónia

Táxus, yew tree

Téktona, Indian oak, or teak-rood

Teléphium, true orpine

Terámnus

Terminália

Ternstróemia

Tetrácera

Tetragónia

Tetráphís

Teúcrium, germander

Tetrápteris

Thalia, Indian arrow-root 4.4

Thælæphóra

Thalíctrum, meadore rue

117

49

130

140

174

164

65

74

130

166

100

173

109

130

176
Page

Thépsia deadly carrot

17 Thea, tea

92 Thelígonum, dog's cab-

69 bage, or mercury 156

89 Theobróma, chocolate nut,

Theophrásta

133

63

Thésium, base fluellin 68

Thláspi, shepherd's purse 117.

Thouinia

Thrínax

Thryállis

48

63 Thúja, arbor vita $\quad 157$

95 Thunbérgia 113

Thy'mbra, mountain hyssop

110

Thy'mus, thyme

110

Tiarélla, American sanicle 91

Ticoréa

119

162 Tília, lime, or linden tree 102

141 Tillæa, small annual

104

98

105

\section{houseleek}

59

Tillándsia

Tímmia,

Tínus

86

Toluifera, Zalsam of tolu tree

88

Toméx

93

Tonsélla

49

Tordy'lium, hart-wort $\quad 71$

Torénia 110

Tormentílla, tormentil $\quad 99$

Tortúla $\quad 173$

Tournefórtia $\quad 64$

Tózzia

Trachélium, true umbelli-

ferous throat-wort 65

Tradescántia, Virginian spider-wort

Trágia

Tragopógon, goat's beard 139 
Trápa, water caltrops

Tremélla, star-jelly

Tréwia

Page

Page

Triánthema, horse purslain

Tríbulus, caltrops

Trichília, suntul

Trichománes, Tunbridge maiden hair

Trichosánthes, serpent cucumber

'Trichostéma

Turnéra, nettle-leaved cis-

175 tus

74

103 Turræ'a

89

Turrítis, tower mustard 116

90 Tussilágo, colt's foot 142

89 Ty'pha, cat's tail, or reed

89 mace

153

171

U

158 Ulmus, elm tree

110 Ulva $\mathbf{1 7 5}$

Trichóstomum 173 Uncária 63

Trídax, trailing starwort 142 Uníola, sea-side oats of

Trientális, winter green

- with chickweed floreers

Unóna Carolina

U'nxia

Trifólium, trefoil

Uréna, Indian mallow

$14 \%$

Triglóchin, arrow-headed grass

Trigonélla, fenugreek

Urtíca, nettle

123

81 Utriculária, bladder-reort 47

Trigónis

Triguéra

1.32

Uvária, grape-wort

106

S4 Uvulária

80

Trílix

119

Tríllium, three-leaved

100 nightshade

Trilocárpus

Triópteris

Triósteum, fever root

Tripláris

Trípsacum

Tríticum, wheat

8

\section{1}

Vaccínium, cranberries

83

104 Valantia, crosscoort

Valantia, crosswort 166

91 Valentínia 84

66 Valeriána, valerian 50

54. Valléa 101

153 Vallisnéria $\quad 160$

53 Vandéllia 111

Triumfétta

94. Varrónia

64

Tróllius, globe ranunculus 105 Vatéria 102

Tróphis

161 Vática

94

Tropæ'olum, nasturtion

Tulbágia

Túlipa, tulip

84. Valézia

70

78 Vélla, Spanish cress 117

79 Verátrum, white hellebore 166 
Page

Verbáscum, mullein

Verbéna, vervain

Verbesína, naked-headed hemp agrimony

Verónica, speedwel

Verrucária

Vibúrnum, pliant mealy tree

Vícia, vetch, bean

Vínca, periwinkle

Víola, violet

Virgília

Virécta

Víscum, mistletoe

Visnéa

Vítex, agnus castus

Vítis, vine

Volkaméria

w

Wachendórfia

Walthéria

Weigéla

Webéra

Wedélia

Weinmánnia

Wéissia

Willíchia

Wintéra

Witsénia

Wulfénia

Wurmbéa
63

48. Xánthium, lesser burdock 154.

Xeránthemum, Austrian

142

47

174

73

130

63

145

] 67

65

161

95

113

67

19 sneezewort

Ximénia

141

Xiphídium

Xylophy'lla

84

Xylópia

Xylósmo

Xy'ris

Xy'stris

50

73

150

156

50

60

$\mathbf{Y}$

Yúcca, Adam's needle so

Zámia

Zannichéllia,triple-headed

Zanónia pondreed

152

162

50 Zanthóxylum, tooth-ache

119 tree, or Hercules's

60 club 162

173 Zéa, Indian corn 153

167 Zínnia 142

85 Zizánia, wild rice 155

173 Zizíphora, Syrian field

50 basil 48

106 Zøgæ'a 143

50 Zostéra, grass wrack 150

47 Zygophy'llum, bean caper 89 



\section{INDEX}

OF SUCH

\section{TRIVIAL NAMES}

A W ERE

\section{THE GENERA OF OLD AUTHORS.}

$\begin{array}{lll}\text { Abelmóschus } & \text { Musk-seed } & \text { Hibiscus } \\ \text { A'bies } & \text { Fir } & \text { Pinus } \\ \text { Abrótanum } & \text { Southern-wood } & \text { Artemisia } \\ \text { Absínthium } & \text { Wormwood } & \text { Artemisia } \\ \text { A'bsus } & \text { Four-leaved cassia } & \text { Cassia } \\ \text { Abútilon } & \text { Indian mallow } & \text { Sida } \\ \text { Acánga } & & \text { Bromelia } \\ \text { Acánthium } & \text { Cotton thistle } & \text { Onopordon } \\ \text { Acárna } & \text { Blessed thistle } & \text { Cnicus } \\ \text { Acetábulum } & \text { Joint cupmoss } & \text { Peziza } \\ \text { Acetósa } & \text { Sorrel } & \text { Rumex } \\ \text { Acetosélla } & \text { Wood sorrel } & \text { Rumex } \\ \text { Achilæ'a } & \text { Milfoil, yarrow } & \text { Oxalis } \\ \text { Achyrántha } & & \text { Chrysanthemum } \\ \text { Ać́doton } & \text { Box-leaved adelia } & \text { Allecebrum } \\ \text { Acinodéndron } & \text { American gooseberry } & \text { Melastoma } \\ \text { A'cinos } & \text { Wild, or stone basil } & \text { Thymus } \\ \text { Acicanthéra } & & \text { Rhexia } \\ \text { Acmélla } & & \text { Spilanthus } \\ \text { Adhadóta } & \text { Malabar nut } & \text { Justicia } \\ \text { Ad́́antum } & \text { Black maiden hair } & \text { Asplenium } \\ & & \end{array}$




\begin{tabular}{|c|c|c|}
\hline $\mathbb{E}^{\prime}$ gilops & Prickly-cupped oak & Quercus \\
\hline Eginétia & Broom rape & Orobanche \\
\hline Eithíopis & Atthiop & Salvia \\
\hline Agállocha & Wood aloes & Excoecaria \\
\hline Agástachys & $r$ & Carex \\
\hline Agératum & Sweet maudlin & Achillea \\
\hline Agéria & & Pæderota \\
\hline Agnus Castus & Chaste tree & Vitex \\
\hline Agrimonoídes & Base agrimony & Agrimonia \\
\hline Ahóvai & & Cerbera \\
\hline Ajácis & & Delphinium \\
\hline Aizoon & Yellow stone crop & Sedum \\
\hline Alatérnus & False phyllirea & Rhamnus \\
\hline A'lcea - & Mallow hollyhock & Malva \\
\hline Alhági & French honeysuckle & Hedysarum \\
\hline Alicástrum & Bread-nut tree of Jamaica & Brosimum \\
\hline Alkekéngi & Winter cherry & Physalis \\
\hline Alliária & Sauce alone & Erysimum \\
\hline Ally'sson & Madwort of Galen & Marrubium \\
\hline A'lnus & Alder & Betula \\
\hline Aloídes & Water aloe, or water soldier & Stratiotes \\
\hline Alopecúrum & Fox-tail grass & Hypnum \\
\hline Alsinástrum & & Elatine \\
\hline Altáica & & Sibbaldia \\
\hline Aly'pum & Blue daisy & Globularia \\
\hline Amalágo & Rough-leaved pepper & Piper \\
\hline Amaránthoides & Amaranth & Axyris \\
\hline Amarélla & Autumnal gentian & Gentiana \\
\hline Amelanchier & & Mespilus \\
\hline Amellóides & & Cineraria \\
\hline Améllus & & Calea \\
\hline A'mmi & Bishop's weed & Sison \\
\hline Ammódytes & & Astragalus \\
\hline Amómum & & Sison \\
\hline Ampelóprasum & & Allium \\
\hline Amsónia & & Tabernæmontana \\
\hline Anacámpseros & Evergreen orpine & Sedum \\
\hline Anagállis & Pimpernel, water & Veronica \\
\hline Anánas & Pine apple & Bromelia \\
\hline
\end{tabular}




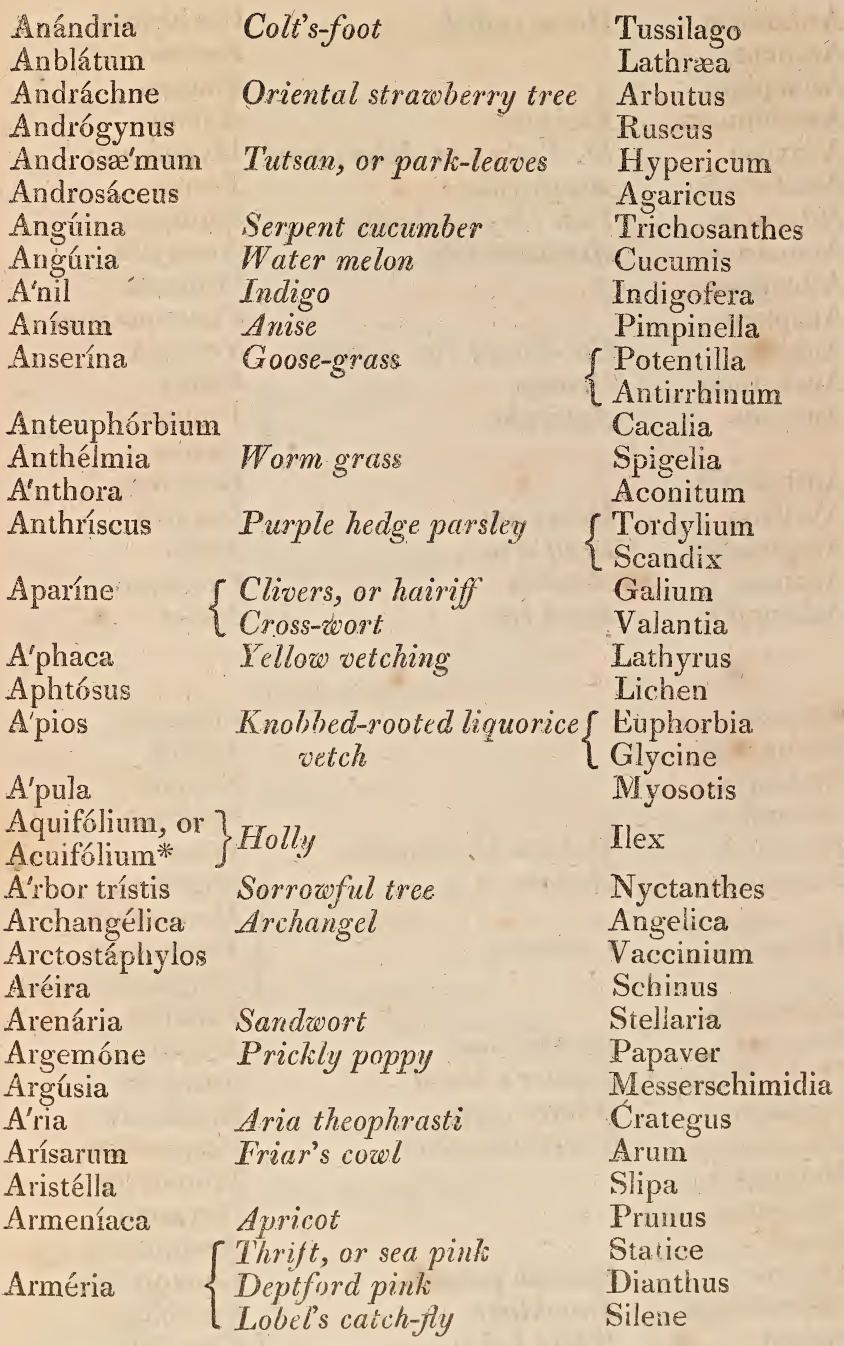

* See Skinner's Etimo, Ling. Anglicance.

$2 E$ 


\begin{tabular}{|c|c|c|}
\hline Armorácia & Horse radish & Cochlearia \\
\hline Arúncus & & Spiræa \\
\hline Asclépium & & Thapsia \\
\hline Ascolónicum & Eschalots & Allium \\
\hline A'scyron & St. Peter's or John's wort & Hypericum \\
\hline Assafo'tida & Assafatida & Ferula \\
\hline Asteríscus & Base chrysanthemum & Silphium \\
\hline Atamásco & Atamasco lily & Amaryllis \\
\hline Athanásiæ & & Othonna \\
\hline Atríplicis & & Chenopodium \\
\hline Aublétia & Cut-leaved rose vervain & Verbena \\
\hline Aurántium & Orange & Citrus \\
\hline Aurícula & Auricula & Primula \\
\hline Auriculária & - & Hedyotis \\
\hline Avellána & Hazel nut & Corylus \\
\hline Azadiráchta & Bead tree & Melia \\
\hline Azárolus & Azarole & Cratægus \\
\hline Azédarach & Bead tree & Melia \\
\hline
\end{tabular}

B.

Badúcca

Bæómyces

Bæóthryon

Balánghas

Balsámea

Balsámina

Balsam of Canada

Balsam

Balsamíta

Costmary

Bálsamum

Bámbos

Bambu cane

Barba Jóvis

Barbárea

Jupiter's beard

Báromez

Winter cress

Tartarian lamb

Bart'ramia

Basílicum

Bássii

Batátas

Beccabúnga

Spanish potatoe

Béhen

Brooklime

White behen

Capparis

Lichen

Scirpus

Sterculia

Pinus

$\{$ Impatiens

$\{$ Momordica

STanacetum

$\{$ Chrysanthemum

Toluifera

Arundo

Anthyllis

Erysimum

Polypodium

Triumfetta

Ocymum

Ambrosinia

Convolvulus

Veronica

Cucubalus

Silene

Centaurea 


\begin{tabular}{|c|c|c|}
\hline Belladónna & Deadly nightshade & S Atropa \\
\hline Bellidiástrum & Middle daisy & $\left\{\begin{array}{l}\text { Doronicum } \\
\text { Osmites }\end{array}\right.$ \\
\hline énghas & & Gluta \\
\hline Benjamína & & Ficus \\
\hline Bénzoe & Benjamin tree & Croton \\
\hline Bénzoin & Benjamin tree & $\left\{\begin{array}{l}\text { Laurus } \\
\text { Terminalia }\end{array}\right.$ \\
\hline ergána & & Erica \\
\hline Bermudíanum & & Sisyrinchium \\
\hline Bernárdia & Base ricinus & Adelia \\
\hline Bétle & Betle & Piper. \\
\hline Betónica & & Justitia \\
\hline Bétulinum & & Agopricon \\
\hline Bêtulus & Hornbeam & Carpinus \\
\hline Bídens & Tickseed sunflower & Coreopsis \\
\hline Bíhai & Banana & Heliconia \\
\hline Bilímbi & - corate & Averrhoa \\
\hline Bistórta & Bistort, or snake-weed & Polygonum \\
\hline Blattária & Moth mullein & Verbascum \\
\hline joídes & & Hieracium \\
\hline Bléchnum & & Ruellia - \\
\hline Blítum & Blite & Amaranthus \\
\hline Bóna Nox & & $\left\{\begin{array}{l}\text { Ipomoea } \\
\text { Smilax }\end{array}\right.$ \\
\hline Bonaróta & Rock germander & Pæderota \\
\hline Bón & Nicker tree & Guilandina \\
\hline ccélla & & Guilandina \\
\hline Henrícus & Garden mercury & Chenopodium \\
\hline Borbónia & Bay tree of Carolina & Laurus \\
\hline Bosvallểa & & Verbesina \\
\hline Botryápium & & Pyrus \\
\hline Bótr & Oak of Jerusalem & $\left\{\begin{array}{l}\text { Chenopodium } \\
\text { Teucrium }\end{array}\right.$ \\
\hline Bov & Fuz, or puff ball & Lycoperdon \\
\hline & & Ehretia \\
\hline Bré & & Capparis \\
\hline Brit & & Rumex \\
\hline Briz & & Poa \\
\hline Bruníades & & Protea \\
\hline Bryántha & & Andromeda \\
\hline
\end{tabular}


Bryópteris

Búceras

Bulbocástanum Pig, or earth nut

Bulbocódium

Búnius

Bursa Pastóris Shepherd's purse

c

Caapéba

Cacáo

Cajan

Caínito

Cakile

Cálaba

Calabúra

Calamagnóstis

Calamíntha

Cálamus

Calamint

Calceolária

Sweet rusk

Calcéolus

Calcitrápa

Slipper

Caléndula

Callicórnia

Callocócca

Caly'cina

Cámara

Ladies' slipper

Star thistle

Marigold

Cámeu-clits-see Quamoclits

Cámmarum Variegated monk's hood

Campánula

Campechiánum

Campechiénse

Cámphora

Cándel

Candelábrum

Cannábina

Bell-flower

Camphor tree

Candel of the Indians

Base hemp
Lycopodiurs

Bucida

Bunium

r Ixia

$\{$ Narcissus

$\int$ Ethusa

\{ Stilago

Thlaspi

Cissampelos

Theobroma

Cytisus

Chrysophyllum

Bunias

Calophyllum

Muntingia

$\{$ Agrostis

$\{$ Arundo

Melissa

Acorus

Viola

Cypripedium

Centaurea

Arctotis

Leysera

Cordia

Festugo

Lantana

Aconitum

Canarina

Hæmatoxylum

Solanum

Laurus

Rhizophora

Ceropegia

Althæa

Tragia

Urtica

Datisca

Cantábric:
Convolvulus 
Cantaréllus

Capíllus Véneris Maiden hair

Caprifólinm Honey-suckle

Cáput Gálil Cock's head

Cáput Medúsæ Medusa's head

Caracálla

Caragána

Caránbola

Carándas

Cardamínes

Cardamómum

Sensitive tree

Cardíaca Mother-wort

Cardamum

Agaricus

Adianthum

Lonicera

Hedysarum

$\{$ Euphorbia

$\{$ Elymus

Phaseolus

Robinia

Averrhoa

Carissa

Lepidium

Amomum

Leonurus

Cardinális

$\left\{\begin{array}{c}\text { Cardinal flower, or water } \\ \text { gladiole }\end{array}\right\}$

Carduélis

Carduncéllus

Cardúnculus

Cárica

Cardoon

Carolínum

Caróta

Carpática

Carpíneus

Cárui

Caryophy'llus

Caroliniána

Carpóbolus

Cascarilla

Cássia

Cassíne

Cassinóides

Castánea

Catálpa

Catáppa

Catária

Cátechu

Carrot

Lobelia

Arctium

Carthamus

Cynara

Ficus

Menispermum

Daucus

Campanula

Lichen

Caraway

Carum

Carnation

Dianthus

Verbena

Lycoperdon

Bark of elutheria

Base cinnamon

Croton

Laurus

South-sea tea

Chestnut

Ilex

Viburnum.

Fagus

Bignonia

Terminaliz

Cat-mint, or nep

Terra japonica

Nepeta

$\{$ Mimosa

Cédrus

Cedar.

Céiba

Celósia

Silk cotton-tree

Cémbra

Centauréum

Cembro pine

Centaury

Areca

Pinus

Bombax.

Iresine

Pinus

Centaures 
Centauríum

Centauroídes

Lesser centaury

Onion

Cherry

Ceratoídes

Ceratónia

Charefólium Garden chervil

Cérris

Cervária

Cerviána

Cervicária

Cervínum

Céterach

Chamæbúxus*

- Chamæcístus

Chamæcrísta

ChamæCyparíssus Lavender cotton

Chamæe'drys

Chamæjásme

Germander

Chamæilea

Spleen-wort

Low box

Chamæ Méspilus Dwarf medlar

Chamæmílla

Chamæ Móly

Chamæmórus

Chamæpénse

Chamæpithys Ground pine

Chamæsy'ce

Champáca

Charácias

Charántia

Cháte

Chéiri

Cheiranthus

Chenópoda

Chína

Chinénsis

Chirónium
Gentiant

f Gnicus

$\{$ Centaurea

Allium

Sedum

Prunus

Axyris

Mimosa

Scandix

Quercus

A thamanta

Pharnaceum:

Campanula

Lycoperdon

Asplenium

Polygala

Rhododendron

Cassia

Santolina

$\{$ Veronica

\{ Teucrium

Stellera

Tragia

Mespilus

Matricaria

Allium

Rubus

Stæhelina

Teucrium

Euphorbia

Michelia

Euphorbia

Momordica

Cucumis

Cheiranthus

Manulea

Marchantia

Smilax

Valeriana

Laserpitium

* Chamo is from the Greek, and means low, humble, or tending to the ground. 
Chloróxylon

Chordorrhíza

Chrysánthum

Chrysógonum

Chytracúlia

Cícer

Cícera

Cichorácea

Cícla

Cinerária

Cinnamómum

Cistóides

Citrúllus

Clandestína

Cláva Hérculis

Clavénnæ

Claytónia

Clématis

Cly'menum

Cneórum

Cóbbe

Coccífera

Cóculus

Coeli Rósa

Cœ'cius

Colocásia

Colocy'nthis

Cólpoon

Colubrína

Colúrna

Comaáurea

Comínia

Conóides

Consólida

Contrajérva

Convólvulus

Conyzóides

Copállinum

Coracánus
Laurus

Carex

Rhododendron

Leontice

Myrtus

Astragalus

Lathyrus

Centaurea

Beta

Centaurea

Laurus

Tribulus

Cucurbita

Water melon, or citrul

Lathræa

Zanthoxylum

Achillea

Osmunda.

Mutisia

Chickling veich

Lathyrus

$\{$ Convolvulus

Daphne

Rhus

Scarlet-grain, or kermes oak Quercus

India-berry

Dewberry, bramble

Great Egyptian arum

Menispermum

Agrostemma

Rubus

Arum

$\left\{\begin{array}{c}\text { Cologuintide } \\ \text { gourd }\end{array}\right.$

Cucumis

Euonymus

Thesium

Stychnos

Byzantine nut

Goldy locks

Corylus

Chrysocoma

Rhus

Silene

Wound-wort

Contrayerva

Delphinium

Dorslenia

Polygonum

Base hemp agrimony

Gum copal
Ageratum

Rhus

Cynosurus 


\begin{tabular}{|c|c|c|}
\hline Corállinus & Liver-wort & Lichen \\
\hline Corallodéndrum & Coral tree & Erythrina \\
\hline Coralloídes & Liver-wort & Clavaria \\
\hline Corailorhíza & & Ophrys \\
\hline Cordifólia & & Cissus \\
\hline Coriária & & Rhus \\
\hline Coríndum & Heart-seed. & Cardiosperm \\
\hline Córis & & Hypericum \\
\hline Corónaria & hnis, or rose campion & Agrostemma \\
\hline Corónopus & $\left\{\begin{array}{c}\text { Bucks-horn plantam, } \\
\text { swoine's cress }\end{array}\right.$ & $\mathrm{Cocl}$ \\
\hline Cóta & & Anthemis \\
\hline Cótinus & Venice sumach & Rh \\
\hline Cotoneáster & Dwarf medlar & Mespilus \\
\hline Cótula & May roed & Anthemis \\
\hline Cotylédon & & raga \\
\hline Coúrbaril & Locust tree & Hymenæa \\
\hline Crácca & & Vicia \\
\hline Crís & & Casalpina \\
\hline Castrénsis & Camp crest & Hypnum \\
\hline Crís & Cock's comb & $\begin{array}{l}\text { Rhinanthus } \\
\text { Erithrina } \\
\text { Hedysarum }\end{array}$ \\
\hline Cro & Drop-wort hemlock & Oenanthus \\
\hline $\mathrm{CrO}$ & & Lichen \\
\hline ly'lium & Centaury without stems & Centaurea \\
\hline pétalum & & Rh: \\
\hline Cruciáta & Cross-wort & Valantia \\
\hline Crupína & & Centaurea \\
\hline Crux Andreæ' & & Ascyrum \\
\hline Crus Córvi & & Panicum \\
\hline Gálli & & Panicum \\
\hline Cúb & Cubebs & Piper \\
\hline Cucularia & & Valantia \\
\hline Cucullaria & Fumuterre with nakedstalh & ¿ Fumaria \\
\hline Cujéta & Calabash tree & Crescentia \\
\hline Culílaban & & Laurus \\
\hline Cunónia & Persian corn flag & Antholyza \\
\hline $\mathrm{Cu}$ & & Lythrum \\
\hline Cúrcas & Physic nut & Jatropha \\
\hline Curúru & & Paullinia \\
\hline
\end{tabular}


Cy'anus

Cycádis

Blue bottle

Centaurea

Cydónia

Quince tree

Zamia

Pyrus

Cymbalária Ivy-leaved wall snapdragon Antirrhinum

Cymínum

Cynápium

Cumin

Cuminum

Cynaroídes

Cynocrámbe Dog's cabbage

Cynophallóphora

Cy'nops

Cynósbati

Cyparíssias

Cytisoídes

$\left\{\begin{array}{c}\text { Lesser hemlock, or fool's } \\ \text { parsley }\end{array}\right\}$ Ethusa

D

Dabóecia

Dáctylon

Daléa

Dalibárda

Damascéna

Damasónium

Dandelíon

Dens Cánis

Dicéra

Dictámnus

Diervílla

Disérmas

Dónax

Dória

Dorónicum

Dortmánna

Dory'cnium

Drába

Protea

Theligonum

Capparis

Plantago

Ribes

Euphorbia

Anthyllis

Andromeda

Panicum

$\{$ Psoralea

$\{$ Eupatorium

Rubus

Nigella

Star-headed water plantain Alisma

Dráco

Dog's-tooth violet

Dittany

Tragopogon

Erythronium

Elæocarpus

Origanum

Lonicera

Salvia

Arundo

Golden rod

Senecio

Senerio

Water gladiole

Lotielia

Shrub trefoil

$\{$ Convolvulus

$\{$ Lotus

Cochlearia

S Dracana

$\{$ Pterocarpos

Dracóntium

Dracúnculus

Arum

Drakéna

Artemisia

$\left\{\begin{array}{l}\text { Dragon-wort, or tarragon Arte } \\ \text { Dragons }\end{array}\right.$

$2 x$

Dorstenia 
Dryméia

Dryópteris

Dudáim

Dulcamára

E

E'benum

E'benus

E'bulus

Ecastaphy'llum

Ecbólium

Echínus

Echioídes

Eglantéria

Elatérium

Elatíne

Elégia

Elemífera

Eléngi

E'lephas

Ellísia

Elutéria

E'mblica

E'mbolus

E'merus

Endívia

Entáda

Ephémerum

Epidéndrum

Epiglóttis

Epipáctis

Epipogíum

Epíthymum

Eragróstis

Erinácea

Erínus

Eriópila

Erisithales

$\left\{\begin{array}{c}\text { Bitter, sweet, or woody } \\ \text { nightshade }\end{array}\right\}$ Solanum

Ehony

Dwarf alder

Ox-tongue

Eglantine

Spurting cucumber

Female speedroell

Gum elemi

Elephant's head

Sea-side laurel

Scorpion senna

Endive

Virginia spider-wort

Carex

Polypodium

Cucumis

Diospyros

Aspalathus

Sambucus

Pterocarpus

Justitia

Statice

Picris

Rosa

Momordica

$\{$ Antirrhinum

$\{$ Campanula

Restio

Amyris

Mimusops

Rhinanthus

Duranta

Clutia

Phylanthus

Mucor

Coronilla

Cichoreum

Mimosa

Lysimachia

Lycoperdon

Astragalus

Astrantia

Satyrium

Cuscuta

Dodder of thyme

$\{$ Poa

$\{$ Briza

Spanish hedge-hog thorn Anthyllis

f Campanula

LLobelia

Duroia

Cnicus 


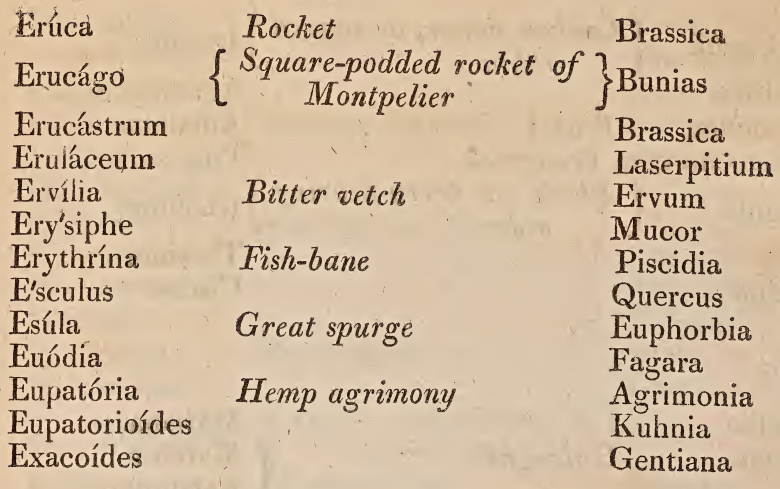

\begin{tabular}{|c|c|}
\hline Fába & Vicia \\
\hline Fabágo & Zygophyllum \\
\hline Fabárius & Cucubalus \\
\hline Fagíneus & Lichen \\
\hline Fagopy'rum & Buck or beech wheat; brank Polygonum \\
\hline Falcária & Sium \\
\hline Falcáta & Adenanthera \\
\hline Falx & oon trefoil \\
\hline Fárfara & Common colt's-foot \\
\hline Farsétia & Cheiranthus \\
\hline Fávus & Boletus \\
\hline Ferulágo & Ferula \\
\hline Ficária & Ranunculus \\
\hline Ficoídes & Base fig marigold \\
\hline Fícus I'ndica & Indian fig \\
\hline Filipéndula & Drop-wort \\
\hline Fúlix Mas & Polypodium \\
\hline Fúlix Fœ'mina & Female fern \\
\hline Fílum & Fucus \\
\hline Fístula & Cassia fistula \\
\hline Flámmula & Flamula jovis \\
\hline Flávium & $\begin{array}{l}\text { Ranunculus } \\
\text { Allium }\end{array}$ \\
\hline Flos A'eris & Epidendrum \\
\hline Flos A'quæ & Byssus \\
\hline
\end{tabular}


Flos Cucúli $\left\{\begin{array}{c}\text { Cuckoo flower, or rag'ged } \\ \text { robin }\end{array}\right\}$ Lychis

Fios-Jóvis

Foenículum Fennel

Fœenum Græ'cum Fenugreek

Frángula $\left\{\begin{array}{c}\text { Black, or berry-bearing } \\ \text { alder }\end{array}\right\}$ Rhamnus

Friséa

Fumána

Thesium

Cistus

c

Galáctia

Galánga Galangal

Galáxia

Gálbanum

Galbanum

Gále

Gale, or sweet willow

Galeóbdolon

Yellow archángel

Genistoídes

Gentianóídes Base gentian

Gerascánthus

Gerbéra

Géum

Kidney-wort

Gingídium

Githágo

Gláucium

Cockle, or poppls

Glaux

Gloriósa

Yellow-horned poppy

Gmelíne

Adam's needle

Gnémon

Gnídıa

Gnídium

Granátum

Flax-leaved laured

Grandarúca

Pomegranate

Gránum Paradísi Grains of Paradise

Grossulária

Gooseberry

Grossularioídes

Gry'llus

Guazúma

Gútta

Base cedar of Jamaica

Gamboge, or camboge

Mariana

f Maranta

\{ Kaempferia

Ixia

Bubon

Myrica

Galeopsis

Sophora

Sarothra

Cordia

- Arnica

Saxifraga

Daucus

Agrostemmá

Chelidonium

Astragalus

Yucca

Cortusa

$\{$ Hieracium

Gnetum

Passerina

Daphne

Punica

Justicia

Amomum

Ribes

Melastoma

Andropogon

Theobroma

Cambogia 
FROM OLD GENERA.

II

Halicácaba

Halicácabum

Halimóides

Hálimus

Halléri

Halodéndron

Hármala

Háspan

Hedy'pnois

Heistéria

Helénium

Heleonástes

Helianthemum

Hélix

Shrubby sea orach

Wild Syrian rue

Erica

Cardiospermum

Portulaca

Atriplex

Arabis

Robinia

Peganum

Cyperus

Hyoseris

Polygala

Elecampane

Inula

Carex

$\left\{\begin{array}{c}\text { Little sun-flower, or } \\ \text { dwarf cistus }\end{array}\right\}$ Cistus

$\int$ Common ivy

Hedera

$\left\{\begin{array}{c}\text { Dwarf yellow, or rose } \\ \text { willow }\end{array}\right\}$ Salix

Hemionítis IMule's fern

Hepática Noble liver-wort

Hérba Vénti

Hieracioídes Basehawkreed

Híppo-castanum Horse chestnut

Híppo-márathum Horse fennel

Hírculus

Urine-zoort

Holoschóenus

Holóstea

Stitch-wort

Hormínum

Hóspita

Hyacinthoídes

Hybánthus

Hydnóra

Hydrópiper

$\left\{\begin{array}{c}\text { Purple-topped sage, or } \\ \text { clary }\end{array}\right\}$

Asplenium

Anemone

Phlomis

Picris

Esculus

Seseli

Saxifraga

Scirpus

Stelleria

Salvia

Kleinhovia,

Aletris

Viola

Aphyteia

$\{$ Water pepper, or arse-smart Polygonum

Hypericoídes St. Peter's wort

Hypnoídes Lady's cushion

Hypocístis Rape of Cistus

Hypoglóssum Tongue laurel

Hypophyllocarpodéndrum

Hypophy'llum

Hypópithys

Elatine

Ascyrum

Saxifraga

Cytinus

Ruscus

Protea

Ruscus

Monotropa 
Hypóxilon

Hyssópifólia

Hysteróphorus Base feverfuge

Hy'strix

I

Jabotápita

Jácea

Jacobæ'a

Knap, or knob-reed

Jalápa

Jánipha

Jámbos

I'beris

Icáco

I'lex

I'nga

Inophy'llum

Insectórius

I'ntsia

I'ntybus

Jolithus

Jonquílla

Jonthláspi

Ipecacuánhæ

I'ria

I'rio

Ischáemum

I'sora

Jujúba

Julácéa

Juláceum

Juliána

Jungermánnia

Cock's-foot grass

Screrv tree

Jonquil

Treacle mustard

Base ipecacuana

Junipérinus

I'va

I'xina
Clavaria

Lythrum

Parthenium

Aristida

Elymus

Barleria

Aspalathus

Ochua

Centaurea.

Senecio

Convolvulus

Mirabilis

Jatropha

Eugenia

Lepidium

Chrysobalanus

Quercus

Mimosa

Calophyllum

Rhamnus

Mimosa

Cichorium

Byssus

Narcissus

Clypeola

$\{$ Euphorbia

$\{$ Viola

Cyperus

Sisymbrium

Andropogon

Helicteres

Rhamnus

Jungermannia

Hypnum

Satureja

Mnium

Lichen

Teucrium

Crameria 
FROM OLD GENERA.

15

Káki

Káli

Kálmanum

Kálmii

Kánki

Káratas

Kléinia

Kolpínia

Stemless wild pine

Foreign colt's-foot

L

Láblab

Labrúsca

Labúrnum

Laccíferum

Lácryma Jóbi

Ládanum

Lagópus

Lántana

Lapathifólium

Láppa

Lappáceum

Láppula

Lárix

Láthyris

Lathyroídes

Lauréntia

Lauréola

Láuro-Cérasus

Lavénia

Lebbék

Léns

Lentágo

Lentíscus

Leonítis

Leontopetaloídes

Leontopétalum. Lion's leaf

Leontopódium

Trefoil tree

Job's tears
Diospyros

Salfola

Hypericum

SHieracium

Lobelia

Minusops

Bromelia

Cacalia

Lapsana

Dolichos

Vitis

Cytisus

Croton

Coix

Galeopsis

Plantago

Viburnum

Polygonum

Arctium

Nephelium

$\int$ Myosotis

$\{$ Trumfetta

Pinus

Euphorbia

Orobus

$\{$ Vicia

Lobelia

Daphne

Prunus

Verbesina

Mimosa

Ervum

Rhus

Pistachia

Phlomis

Leontice

Leontice

Filago 
Leonúrus

Lepidocarpodéndron

Leptáurea

Leptóstachys

Leucadéndron

Leucánthemuin $\left\{\begin{array}{r}\text { Chrysanthemum with } \\ \text { white rays, or ox }\end{array}\right.$

Leucoglóchin eye daisy

Leucóxylon

Levisánus

Levísticum

Libánotis

Lichenoídes

Lígtu

Linophy'llum

Liliágo

Liliástrum

Savoy spider-wort

Lilio-hyacínthus Lily hyacinth

Lúna

Limónia

Limónium

Sea lavender

Linária

Lingúa

Milk, or white wood

Lovage

Toad flax

Linoídes

Linósyris

Línum-Stellátum

Línza

Líppij

Lobélia

Locústa

Loesélii

Lonchítis

Loniceroídes

Lopánthus

Phlomis

Protea

Zoegea

Carex

Melaleuca

Chrysanthemum

Carex

$\left\{\begin{array}{l}\text { Bignonia } \\ \text { Vitex }\end{array}\right.$

Protea

Ligusticum

SAthamanta

Cachrys

Cistus

Mucor

Alstroemeria

Thesium

Anthericum

Anthericum

Scilla

Cynosurus

Campanula

Statice

Antirrhinum

SRanunculus

Othonna

Serapias

Chironia

Chrysocoma

Lysimachia

Ulva

Cistus

Scævola

$\left\{\begin{array}{c}\text { Corn sallad, or lamb's } \\ \text { lettuce }\end{array}\right\}$ Valeriana

Sisymbrium

Polypodium

Loranthus

Hyssopus 
Lucídor

Lúffa

- Luuária

Lupináster

Lúpulus

Lutéola

Lychnídea

Lychnítis

Ly'cia

Lycóctonum

Lycopérsicum

Lygístum

M

Mahágoni

Maháleb

Majorána

Malabáthrica

Malacodéndron

Malácoides

Malamíris

Malocócca

Málus

Malvavíscus

Mancinélla

Mandrágora

Mánghas

Mángle

Mangostána

Mangostánus

Mánihot

Máppa

Marántæ

Marántina

Mariána

$2 \mathrm{G}$ $\begin{cases}\text { Wild jujube tree } & \text { Rhamnus } \\ \text { Lotus of Egypt } & \text { Nymphæa } \\ \text { Lotus, supposed of Homer, } & \text { Diospyros }\end{cases}$

Antholyza

Momordica

$\{$ Rumex

\{ Osmunda

Trifolium

Hop

Wild woad

Base lychris

Olibanum

Wolf's peach

Humulus

Reseda

Erinus

$\{$ Verbascum

\{ Phlomis Juniperus Aconitum

Solanum

Petesia

Swietenia

Prunus

Origanum

Melastoma

Stewartia

Malope

Piper

Grewia

Pyrus

Apple

Berry-bearing hibiscus

Manchineel

Mandrake

Hibiscus

Hippomane

Atropa

Cerbera

Mangrove, or mangle

Mangostan

Cassava

Rhizophora

Garcinia

Amaranthus

- $\int$ Hibiscus

Jatropha

Ricinus

Acrostichum

Globba

Clitoria 


\begin{tabular}{|c|c|c|}
\hline Mariánus & Spotted milk thistle & Carduus \\
\hline Maríscus & & Schoenus \\
\hline Mínnelos & & Cratæva \\
\hline Mártagon & Martag:on lily & Lilium \\
\hline Máru & & Origanum \\
\hline Marrubiástrum & & Leonurus \\
\hline Mlárum & Common marum & Teucrium \\
\hline Mastíchina & Mastich thyme & Thymus \\
\hline Matréla & & Agrostis \\
\hline Matthíoli & Bear's-ear sanicle & Cortusa \\
\hline Máura. & & Antholiza \\
\hline Maurocénia & Hottentot cherry & Cassine \\
\hline Máx & & Phaseolus \\
\hline Máys & Indian, or Turkey wheat & Zea \\
\hline Meadia & American cowslip & Dodecatheon \\
\hline Média & Mock privet & Phillyria \\
\hline Mlédium & & Convolvulus \\
\hline & Canterbury bell & Campanula \\
\hline Meleágris & Weeping widow & Fritillaria \\
\hline Melánium & & Lythrum \\
\hline Melanóphleum & & Sideroxylon \\
\hline Mélilot & Melilot & Trifolium \\
\hline Melittifólia & & Besleria \\
\hline Mélo : & Melor & Cucumis \\
\hline Melocáctus & Melon thistle & Cactus \\
\hline Melóngena & Egg plant & Solanum \\
\hline Melópepo & Buckler gourd & Cucurbita \\
\hline Mercuriális & & Tragia \\
\hline Meriána & & Antholyza \\
\hline Mierianélla & Cape corn flag & Antholyza \\
\hline Metel. & & Datura \\
\hline Metópium & & Rhus \\
\hline Méum & Spignel & Ethusa \\
\hline Mezéreum & Mezereon & Daphne \\
\hline Micránthus & & Rhamnus \\
\hline Microcos & & Grewia \\
\hline liánus & & Scirpus \\
\hline Miliáceus & Millet, or panic grass & Scirpus \\
\hline lórum & & Gnaphalium \\
\hline Millefólium & Milfoil, or yarrow & Achillea \\
\hline Mítra & & Helvella \\
\hline
\end{tabular}


Mitréola

Mnematéia

Mokusín

Monócera

Moldávica

Mólle

Mollúgo

Móly

Mómbin

Monniéria

Monórchis

Morgsána

Morínga

Mório

Móschata

Mórsus Ránæ

Moschatéllina

Moschéutos

Mucéda

Mullúgo

Múngo

Múngos

Múrex

Murucúja

Muscári

Muscípula

Mussénda

Mutellína

Myrobalanus $\left\{\begin{array}{c}\text { Myrobalans, or Jamaica } \\ \text { hog plum }\end{array}\right\}$

Myrsinítes

Myrtíllus

My'stax

Myúrus

My'xa

N

Nápeca

Napéllus

Nápus

$\begin{array}{ll} & \text { Ophiorhiza } \\ & \text { Ehrharta } \\ & \text { Phalius } \\ \text { Visnea } & \text { Dracocephalum } \\ \text { Moldavian balm } & \text { Schinus } \\ \text { Peruvian mastich } & \text { Galium } \\ \text { Moly, with lily flowers } & \text { Allium } \\ \text { Brasilian plum } & \text { Spondias } \\ & \text { Gratiola } \\ & \text { Ophrys } \\ & \text { Zygophyllum } \\ \text { Salep } & \text { Guilandina } \\ \text { Nutmeg } & \text { Orchis } \\ \text { Frog's bit } & \text { Myristica } \\ \text { Tuberose moschatel, or } & \text { Hydrocharis } \\ \text { hollow root } & \text { Adoxa } \\ & \text { Hibiscus } \\ & \text { Mucor } \\ & \text { Pharnaceum } \\ & \text { Phaseolus } \\ & \text { Ophiorrhiza } \\ & \text { Pedalium } \\ \text { Passion flower } & \text { Passiflora } \\ \text { Mrusk hyacinth } & \text { Hyacinthus } \\ \text { Fly-trap } & \text { Dionæa } \\ \text { Catch-fly } & \text { Silene } \\ & \text { Gardenia } \\ & \text { Phellandrium }\end{array}$

Spondias

Euphorbia

Vaccinium

Hugonia

Manisuris

Cordia

Rhamnus

Aconitum

Brassica 
Nardus

Nard, or spikenard

Nastúrtium Cress

Nátrix

Negúndo

Nelúmbo

Nemolápathum

Népeta

Nepetélla

Nídus A'vis

Nigellástum

Nigrína.

$\mathrm{Nil}$

Nínsi

Nirurí

Nissólia

Nissoliána

Nissoliánum

Nóbla

Noli tángere

Nóstoc

Núga

Nummulária

Nummulárius

Nux Vómica

Nycteléa

Indian water lily

Wild cat mint

Bird's nest.

Fennel flower of Crete

Blue bind-weed

Nymphoídes

Base shrubby hare's-ear

Crimson grass vetch

Touch not, or
samine
Money-wort

\{
Andropogon

Sysymbrium

Ononis

$\{$ Vitex

$\{$ Acer:

Nymphæa

Rumex

Melissa

Nepeta

Ophrys

Garidella

Gerardia

Convolvulus

Sium

Phylanthus

Lathyrus

Vicia

Teucrium

Phyllis

Impatiens

Tremella

Guilandina

Lysimachia

Evolutus

Strychnos

Ellisia

Menyanthes

\section{o}

O'chrus

O'culus Cati

Winged pea

Pisum

O'culus Christi

Cat's eye

Ocymoídes

Odontítes

Oenóplia

Oenothéræ

Oleánder

Oleoídes

Christ's eye

Red meadow eye-bright

Ollária

Rose bay

Spurge olive
Gnaphalium

Inula

Saponaria

Euphrasia

Rhamnus

Geranium

Nerium

$\{$ Rhamnus

$\{$ Daphne

Lecythis 


\begin{tabular}{|c|c|c|}
\hline Olusătrum & Alexander & Smyrnium \\
\hline Oly'mpicum & & Hypericum \\
\hline O'mphalodes & Spring navel-wort & Cynoglossum \\
\hline Onobry'chis & $\left\{\begin{array}{l}\text { Saintfoin } \\
\text { Vetchino }\end{array}\right.$ & Hedysarum \\
\hline Onítes & & Origanum \\
\hline Ophioglossoídes & & Clavaria \\
\hline Opobálsamum & . & Amyris \\
\hline Opóponax & & Pastinaca \\
\hline $\mathrm{O}^{\prime}$ pulus & Marsh elder & Viburnum \\
\hline Opúntia & Indian fig & Cactus \\
\hline Orchioídes & & Hyacinthus \\
\hline Orellána & Anotta, or arnotta & Bixa \\
\hline Oreoselínum & Mountain parsley & Athamantha \\
\hline Orientále & & Sicymbrium \\
\hline O'rnus & Ash & Fraxinus \\
\hline Oróntium & & Antirrhinum \\
\hline O'rvala & & Lamium \\
\hline Osbéckii & & Verbascum \\
\hline Ostrúthium & Master-wort & Imperatoria \\
\hline O'strya & Hop horn-beam & Carpinus \\
\hline Otítes & & {$\left[\begin{array}{l}\text { Cucubalus } \\
\text { Polypodium }\end{array}\right.$} \\
\hline édrus & Greater Spanish juniper & Juniperus \\
\hline Oxyc & rry & Vaccinium \\
\hline $\mathbf{p}$ & & \\
\hline Padalianches & & nicum \\
\hline Pádus & Birc & $\operatorname{Pr}$ \\
\hline Paliúrus & Christ's thorn & inus \\
\hline Pánaces & & Heracleum \\
\hline Papáya & Papaw tree & Carica \\
\hline Papy'rus & Egyptian paper & Cyperus \\
\hline Parálias & & Euphorbia \\
\hline Paréira & & Cissampelos \\
\hline Paréllus & & Lichen \\
\hline Parony'chia & Mountain knot grass & Illecebrum \\
\hline Párra & & Sisymbrium \\
\hline Parsón & & \\
\hline Parthénium & Feverfuge & Matricaria \\
\hline & & \\
\hline Passerína & Tragus's sparrow-wort & Stellera \\
\hline
\end{tabular}


Passeríno

Patiéntia

Pávia

Monl's rhubarb

Scarlet horse chestnut

Erica

Rumex

Pécten

$\left\{\begin{array}{c}V \in n u s ' s \text { comb, or shep- } \\ \text { herd's needle }\end{array}\right\}$ Scandix

Pedy'pnois

Pelecínus

$\left\{\begin{array}{c}\text { Clusius's foreign hatchet } \\ \text { vetch }\end{array}\right\}$

Pémphis

Penæ'a

Pentacárpos

Pentagónia

Pentstémon

Tree milk-wort

Péplis

Péplus

Pépo

Péragua

Peréskia

Pumpion

Pericly'menum

Pérsea

Pérsica

Persicária

Persónata

Pes Cápræ

Pes Tígridis

Petasítes

Petroselínum

Phænopy'rum

Phæ'um

Phegópteris

Phéllos

Phelypæ'a

Phlegmária

Phlómidis

Phu

Phyllánthus

Physódes

Phytéuma

Pícæ

Tiger's-foot

Blad apple

Trumpet honeysuckle

Avocado pear

Peach

Persicaria

Pestilent wort

Parsley

Pícea

Garden valerian

Hyoseris

Biserula

Lythrum

Polygala

Hibiscus

Campanula

Chelone

Euphorbia

Euphorbia

Cucurbita

Cassine

Cactus

Lonicera

Laurus

Amygdalus

Polygonum

Arctium

$\{$ Convolvulus

$\{$ Oxalis

Ipomoea

Tussilago

Apium

Mespilus

Geranium

Polýpodium

Quercus

Lathræa

Lycopodium

Clerodendrum

Valeriana

Cactus

Erica

$\{$ Reseda

Crested rampions

Lobelia

Polypodium

Pinus 
Picroídes

Pilosélla

Piménta

Pimpinelloídes

Pínea

Pinéti

Pínguin

Piperélla

Piperíta

Pistolóchia

Pitajáya

Pithyúsa

Plantagíneum

Plantáginis

Plantágo

Platonoídes

Polygonóides

Pneumonánthe.

Podagrária

Pólium

Polifólia

Polluéria

Polygónatum

Polytrichoídes

Porophy'llum

Pompónium

Pontána

Pórrum

Pórtula

Portulacária

Portulacástrum Horse purslain

Portulacoídes

Posopúsa

Potatórum

Prínus

Prionítis

Prótium

Pséudo-Acásia False acacia

Pséudo-Acmélla

Pepper-mint

Mountain poley
Scorzonera

Hieracium

Myrtus

Seseli

$\{$ Euphorbia

Pinus

Helvella

Bromelia

Thymus

Spanish birthwort

Pitajaya of California

$\left\{\begin{array}{c}\text { Marsh cistus; or wild } \\ \text { rosmary }\end{array}\right\}$ Andromeda

Pyrus

Convallaria

Mnium

Cacalia

Lilium

Hypochæris

Allium

Peplis

Claytonia

Sesuvium

Atriplex

Carica

Strychnos

Quercus

Barleria

Amyris

Robinia

Spilanthus 
Pséudo-Acórus Yellow water flag

Pséudo-Cápsicum Amomam plinii

Pséudo-Chína False China root

Pséudo-Cypérus

Pséudo-Cy'tisus

Pséudo-Dictámnus Base dittany

Pséudo-Narcíssus Daffodil

Pséudo-Pithys

Pséudo-Plátanus

Pséudo-Psídium

Psycódes

Psy'llium

Psyllóphora

Ptármica $\left\{\begin{array}{c}\text { Greater maple, or } \\ \text { English sycomore }\end{array}\right\}$

Pteránthus

Pterocéphala

Pteróta

Pulégium

Pulicária

Pulsatílla

Pumílea

Pyracántha

Py'rethrum

Flea-wort

Sneeze-wort

Scabious

Pennyroyal

Marsh flea-bane

Pasque flower

Pyracantha

Pellitory of Spain

Iris

Solanury

$\{$ Senecio

Smilax

Carex

Vella

Marrubium

Narcissus

Teucrium

$\mathrm{g}$

Quámoclit

Indian Pink

Quércinus

Oak agaric

Ipomoea

Agaricus

R

Rádiola

$\left\{\begin{array}{c}\text { All seed, or least rup- } \\ \text { ture wort }\end{array}\right.$

Rangiferínus

Reindeer liver-wort

Rápa

Turnep

Lichen

Brassica

Raphanístrum

Rapuncoloídes

Rapúnculus Rampions

Rhabárbarum Rhubarb

Rhagadioloídes

Rhagadíolus

$\{$ White flowered charlock,

Raphanus

Campanula

Campanula

Rheum

Hyoseris

Iapsana 


\begin{tabular}{lll} 
Rhamnoídes & Sea buckthorn & Hippophæ \\
Rhapúntica & Centaury & Centaurea \\
Rhapónticum & Rapontic & Rheum \\
Rhóeás & Red field poppy & Papaver \\
Ríbes & & Rheum \\
Ricinélla & & Adelia \\
Rícino-carpos & Base ricinus & Croton \\
Rindéra & & Cynoglossum \\
Rinocerótis & & Stoebe \\
Rítro & & Echinops \\
Róbur & Oak & Quercus \\
Roccélla & Orchal & Lichen \\
Rosa Sinénsis & China rose & Hibiscus \\
Rósea & Rose root & Rhodiola \\
Rótang & & Calamus \\
Rothmánnia & & Gardenia \\
Royéni & & Codon \\
Róyoc & & Cactus \\
Rúta Murária & Wall rue & Morinda \\
Ruyschiána & & Asplenium \\
\hline & & Dracocephalum \\
\hline
\end{tabular}

S

Sabdariffa

Sabína

Salicária

Salsílla

Sálsula

Sámbac

Sambúcina

Sanguisórba

Santólinus

Santólina

- Santónica

Saponária

Sápota

Sappán

Sarcocólla

Sarcocómphalus

Sarsaparílla

\& 1

$\left\{\begin{array}{c}\text { Sillow-herb, or purple } \\ \text { loosestrife }\end{array}\right\}$

Hibiscus

Juniperus

Lythrum

Alstroemeria

Phaca

Arabian jasmine

French wormzood

Soap apple

Sapota

Nyctanthes

Aquilicia

Poterium

Pterocarpos

Achillea

Artemisia

$\int$ Gentiana

\{ Sapindus

Achras

Casalpina

Penæa

Rhamnus

Sarsaparilla 


\begin{tabular}{|c|c|c|}
\hline \multirow{2}{*}{$\begin{array}{l}\text { Sássafras } \\
\text { Saxífraga }\end{array}$} & Sassafras tree & Laurus \\
\hline & insum & $\left\{\begin{array}{l}\text { Pimpinella } \\
\text { Gypsophyla }\end{array}\right.$ \\
\hline Saxífragus & & Cucubalus \\
\hline Scabiósa & Scabious & Centaurea \\
\hline Scammónia & Scammony & Convolvulus \\
\hline Scaríola & & Lactuca \\
\hline Scéptrum & & Digitalis \\
\hline Scéptrum Caroli & ánum & Pedicularis \\
\hline Scéptrum Gusta & viánum & Protea \\
\hline Scherardiána & & Malva \\
\hline Schinoídes & & Schrebera \\
\hline Schobéri & & Nitraria \\
\hline Schoenánthus & Camel's hay, or sweet rush & Andropogon \\
\hline Schoenoídes & & Phleum \\
\hline Schoenóprasum & Cives, or chives & Allium \\
\hline Scilláris & & Ixia \\
\hline Sciuroídes & & Hypnum \\
\hline Sclaréa & Clary & Salvia \\
\hline Scolopéndrium & Hart's tongue & Asplenium \\
\hline Scólymus & Artichoke & Cynara \\
\hline Scopária & $\left\{\begin{array}{c}\text { Summer cypress, or } \\
\text { videre }\end{array}\right.$ & Chenopodium \\
\hline Scopólia & & Melaleuca \\
\hline oídes & & Sideritis \\
\hline Scordíum & Scordium & Teucrium \\
\hline Scordótis & & Nepeta \\
\hline Scorodónia & Wood sage & Teucrium \\
\hline Scorodóprasum & $\left\{\begin{array}{c}\text { Great round-headed } \\
\text { Turkey garlic, or } \\
\text { rocambole }\end{array}\right.$ & Allium \\
\hline Scórpius & & Spartium \\
\hline Scúrrula & & Loranthus \\
\hline Sebesténa & Assyrian plum & Cordia \\
\hline Secálinus & & Bromus \\
\hline Secamóne & & Pepiploca \\
\hline Securidáca & Hatchet vetch & Coronilla \\
\hline Sedoídes & & Saxifraga \\
\hline
\end{tabular}




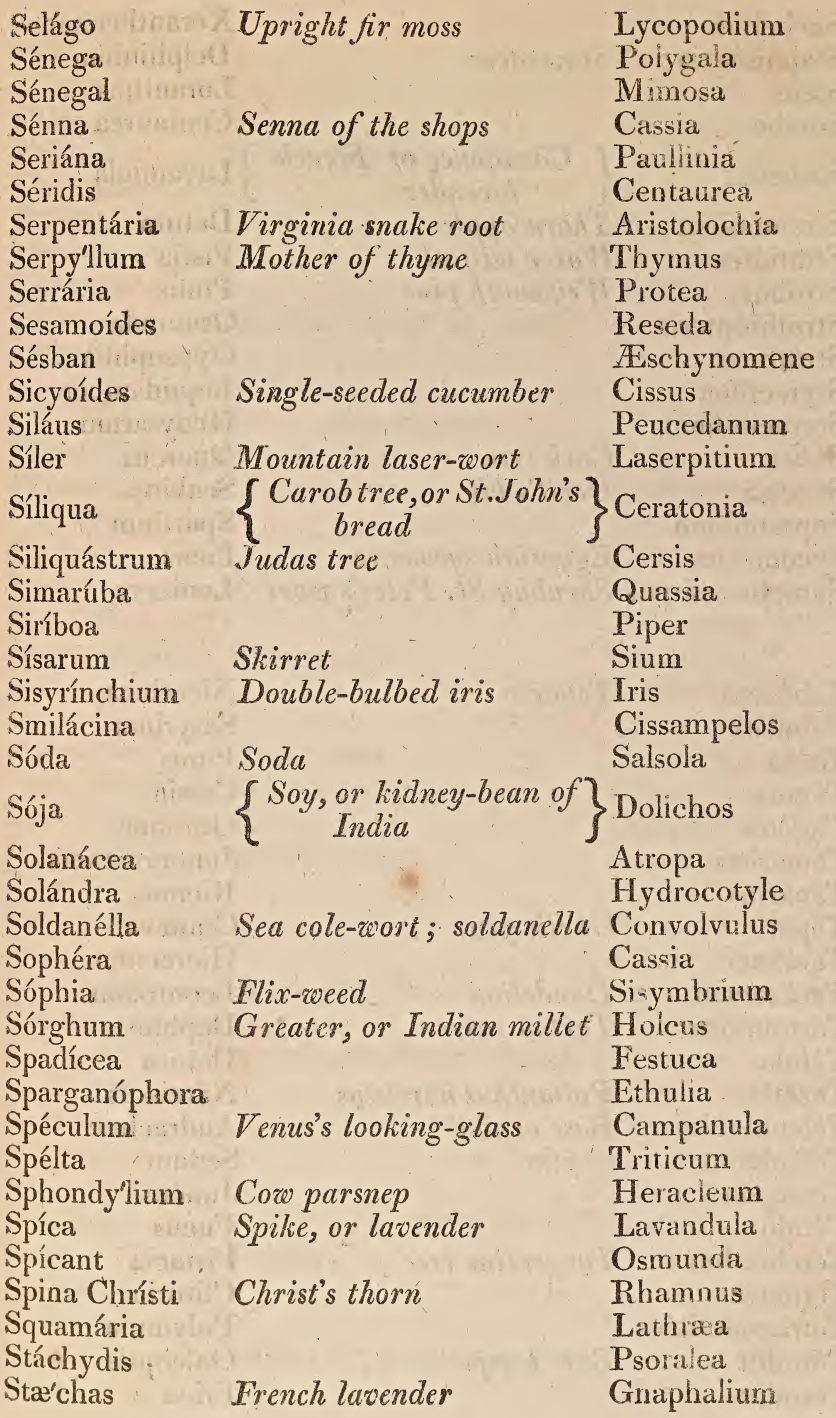


Stæhelína

Staphiságria Stavesacre

Stélis

Stoébe

Stoéchas

Stramónium

Stratiótes

Stróbus

Struthiópteris

Strúthium

Styracíflua

Styracifólium

Súber

Cork tree

Succísa

Devil's bit

Supranúlium

Sycomórus

Symphoricárpus Shrubby St. Peter's wort

Xeranthemum

Delphinium

Loranthus

Centaurea

$\left\{\begin{array}{c}\text { Cassidone, or French } \\ \text { lavender }\end{array}\right\}$ Lavandula Thorn apple

Water milfoil

Weymouth pine

Datura

Pistia

Pinus

Osmunda

Gypsophila

Liquidamber

Hedysarum

Quercus

Scabiosa

Spartium

Ficus

Egyptian sycomore

Lonicera

T

Tabácum

Tobacco

Tabuláre

Tæ'da

Tágera

Tagétes

Tamarísci

Tanárius

Tápia

Taráxací

Taráxacum

Garlic pear

Dandelion

Tartonráira Tarton raire

Nicotiana

Tátula

Tazétta

Polianthus narcissus

Telephioídes

Teléphium

Tenagéia

Téndo

Terebínthus Turpentine tree

Base orpine

Orpine

Ternatéa

Tetragonothéca

Tétrahit

Tétralix

Satyrium

Pinus

Cassia

Othonna

Jungermannia

Ricinus

Cratæva

Hieracium

Leontodon

Daphne

Datura

Narcissus

Andrachne

Sedum

Juncus

Fucus

Pistacia

Clitoria

Polymnia

Galeopsis

Erica 
FROM OTD CENERA.

Téucrium

Thalictroídes

Thápsi

Thapsoídes

Thápsus

Théezans

Thely'pteris

Thevétia

Thomæ'a

Thóra

Thumbérgia

Thy'mbra

Thymeláea

Thymifólia

Thyoídes

Tíglium

Tínus

Tirucálli

Tithymaloídes

Tóra

Tótta

Tournefórtii

Toxicodéndron

Trachélium

Tragacántha

Tragódes

Tragoríganum

Trágus

Trichómanes ramosum Maiden hair

Trichomanoídes

Triónum

Tripólium

Trípteris

Tríxago

Troglodytárum

Tsiámpaca

Túber

Tuberária

Tuberósa

Túna

Túpa

White Mullein

Spurge flax

Laurestinus

Base spurge

Truffles
Veronica

Anemone

Digitalis

Verbascum

Verbascum

Rhamnus

Polypodium

Cerbera

Nardus

Kidney-leaved crowfoot Ranunculus

Gardenia

$\left\{\begin{array}{c}\text { Savory, with verticil- } \\ \text { late flowers }\end{array}\right\}$ Satureja

Daphne

Lythrum

Cupressus

Croton

Viburnum

Euphorbia

Euphorbia

Cassia

Protea

Gundelia

Rhus

Campanula

Astragalus

Fagara

Thymus

Salsola

Asplenium

Asplenium

Kelmia, or Venice mallow Hibiscus

Aster

Valeriana

Rhinanthus

Musa

Michelia

Lycoperdon

Cistus

Polianthes

Indian fig, or prickly pear Cactus

Lobelia 
Túrbith

Turpéthum

'Turríta

Typhalæ'a

Ty'phinum

U

Ulmária

Una Críspa

U'nedo

U'nguis Cati

Uragóga

Urinária

Urtícæ

U'snea

Uva U'rsi

Uvária

Uvedália

Uvífera

v

Vaccária

Valentina

Valerándi

Vanílla

Vascária

Verbenáca

Verbesína

Vérnix

Verútum

Vesicária

Victoriális

Vincetóxicum

Viórna

Virgáurea
Turbith

Sesseli

Convolvulus

Arabis

Urena

Rhus

Spiræa

Ribes

Arbutus

Mimosa

Myginda

Phylanthus

Begonia

Tree moss

Lichen

$\left\{\begin{array}{c}\text { Spanish red-worts, or } \\ \text { bear berries }\end{array}\right\}$ Arbutus

Iris uvaria

Aletris

Polymnia

Coccoloba

Saponaria

Coronilla

Anthemis

Anacyclus

$\left\{\begin{array}{c}\text { Round-leaved water } \\ \text { pimpinel }\end{array}\right\}$ Samolus

Vanilla

Epidendrum

Saponaria

Salvia

Cotula

Poison, or varnish tree Rhus

Centaurea

$\left\{\begin{array}{c}\text { Mad-wort, with blad- } \\ \text { dery pods } \\ \text { Heart seed }\end{array}\right\} \begin{aligned} & \text { Alyssum } \\ & \text { Brassica }\end{aligned}$

Allium

Asclepias

$\left\{\begin{array}{c}\text { Leathery flowered vir- } \\ \text { gin's bower }\end{array}\right\}$

Clematis

Solidago 
Virgínicum

Viscária

Visnága

Vitálba

Vitaliána

Viticélla

Vitis Idáea

Vulnerária

Vulpína

Vulvária

w

Wedélia

$\mathrm{x}$

Xíphium

Xylósteum

Y

Yervamóra

Z

Zacíntha

Zanónia

Zeocrithon

Zerúmbet

Zeugítes

Zeylánica

Zibethínus

Zíngiber

Zizy'phus

Zuzy'gium

Zy'gis

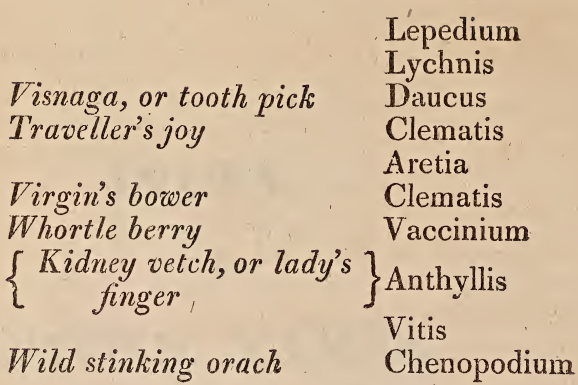

Polymnia

Bulbous iris

Iris

Fly honeysuckle

Lonicera

Bosea

Golden rod tree

$\left\{\begin{array}{c}\text { Wart cichory,ornipple- } \\ \text { wort }\end{array}\right\}$ Lapsana

Commelina

Hordeum

Wild ginger

Amomum

Apluda

Nama

Durio

Ginger

Jujube tree

Spanish thyme
Amomum

Rhamnus

Myrtus

Thymus 


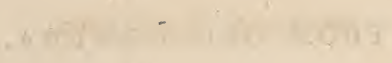

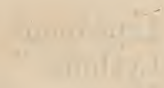

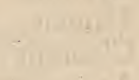

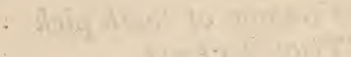

| in | 1 |

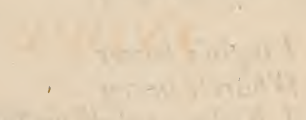

nily

$x=1+1+1+x$

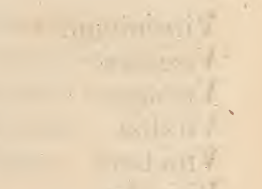

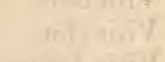

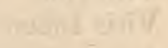

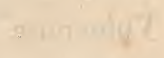

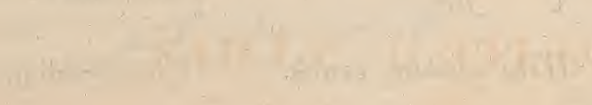

24.

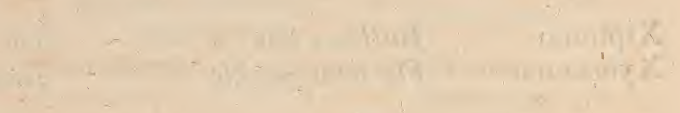
$-$

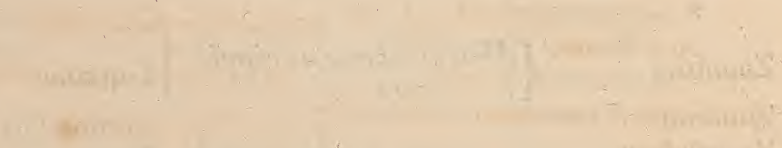
wh own on $\mathrm{k}$

$.+40+5+150$ - nowis. $+2+2+x+1+2$

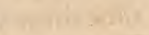

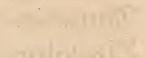
and $1,08+2$ 


\section{INDEX}

OF THE

\section{BRITISH NAMES.}

A Bete (the Dutch name)

Abelmosk ; or musk seed

Acacia, true; or Egyptian Acacia, false; or locust tree Robinia pseud-acacia Acacia, German Acacia, three-thorned; or ho-
ney locust Acajou; or cashew nut Anacardium occidentale $\left.\begin{array}{c}\text { Acanthus,Corinthian; or brank } \\ \text { ursine }\end{array}\right\}$ Acanthus spinosus Acmella Aconite Aconite, Winter Acrostic; or fork fern Adam's needle Adder's wort; or bistort Adder's, or serpent's tongue Adonis, common Agaric Agaric of the oak Agaric (Pharmaco Edinb.) Agnus castus; or chaste tree Agnus castus; oil tree; or palma Christi 2 I Prunus

Populus alba Hibiscus abelmoschus Robinia pseud-acacia Spilanthus acmella Aconitum Helleborus hyemalis Acrostichum septentrionale Yucca gluriosa Polygonum bistorta Ophiogiossum rulgatum Adoris autumnalis Agaricus

Agaricus quercinus Boletus igniarius Vitex agnus castus \} Ricinus communis 
Agrimony, common

A grimony, hemp

Agrimony, base hemp

Agrimony, naked-headed hemp

Agrimony, water hemp

Ague tree; or sassafras

Aikraw

Alaternus

Alaternus, base

Alder

Alder, black, or berry-bearing

Alecost ; or costmary

Alehoof; gill; or ground ivy

Alexanders

Alcali, or sal-kali*

Alcali, or sal-kali, jointed

Alcanet

Alhenna, or henna; or alcanna

Alkekengi

Allgood ; good Henry; or Eng- ? lish garden mercury

Allheal, clown's ; or woundwort
Agrimonia eupatoria

Eupatorium cannálinum

Ageratum cony'zoídes

Verbesína

Bidens tripartita

Laurus sassafras

Lichen

Rhamnus alaternus

Phylica erícö́des

Betula alnus

Rhamnus frangula

Tanacetum balsamita

Glechoma hederácea

Smyrnium olusátrum

Salsoli kali

Salicornia herbacea :

Lithospermum orientale

Lawsonia inermis

Physalis alkekengi

Chenopodium bonus Henricus

Stachys palustris

* A fixed alkali may be extracted from all vegetables; but fumuterrce and wormuood will yield the greatest quantity, and fir the least; one thousand pounds of fumuterric yielded about two hundred and nineteen pounds of ashes, and seventynine of salt; the same quantity of wormwood ninety-seven pounds and a half of ashes, and seventy-three of salt; the same quantity of fir yielded only three pounds and a half of ashes, and half a pound of salt.

Jrish Royal Acudemy, 1791.

The ashes imported from Spain and Russia are said to be the purest and best, and when only in a fine powder, are called pulverine or barilla, but when made into hard lumps, are called rochetta; and M. Lavoisier (in his Elements of Chemistry) says that all vegetables yield more or less salt or pot-ash, in consequence of combustion, which is more or less saturated with carbonic acid; but as this substance cannot be procured but by means of processes capable of furnishing oxygen and azote, such as combustion, or by means of nitric acid; it is therefore as yet uncertain whether it previously existed already formed in the vegetable, or whether it be a produce from these operations.-To obtain the salt or pot-ash, pour about a pound of ashes on a quart of soft hot water, which let stand for a week, frequently stirred; then pour off the water, and if the ashes taste salt, pour on a little more water; then evaporate the water in a shallow vessel, and the salt will remain.-To make pure pot-ash, dissolve this salt in water, then add two or three times its weight of quick lime, filtrate the liquor, and evaporate it in close vessels; by this means it is almost entirely deprived of its carbonic acid, and is soluble in alkohol. Pearl-ash is pot-ash refined by calcination. See note to soda, in the Index. 
Altheal, Hercules's

Allseed; or least rupture-wort All-spice ; or Jamaica pepper

All-spice, Virginian

Alligator; or Arocado pear

Almond

Almond, Fthiopian or African

Almond, dwarf

Aloe, leaf-pierced

Aloe; cobweb

Aloe, socotrine

Aloe, hepatic

Aloe, common American

Aloe, water; or water soldier

Aloes, wood; or calamba

Althæa frutex; or Syrian mallow

Heracleum pánaces

Linum radiola

Myrtus pimenta

Calycanthus floridus

Laurus persea Amygdalus communis

Brabeium stelluifolium

Amygdalus nana

Aloe perfoliata

Aloe pumila arachnoides

Aloe spicata

Aloe perfoliata

Agave Americana

Stratiotes alöídes

Excoecaria agállocha Alysson, rough-leaved; or awlwort Subularia aquatica Amaranthus; or flower-gentle Amaranth, globe

Amaranthus tricolor

Amaryllis, superb

Amber tree

Amellus of Virgil

Ammi

Amomum Plinii

Amomum, German

Anacardium

Andrachne; or oriental strawberry tree

Anemone, common garden

Anemone, wood

Ananas; or pine apple

Angelicat

Amaranthus

Gomphrena

Amaranthus tricolor

Amaryllis vittata

Anthospermum Ethiopicum

Aster amellus

Sison ammi

Solarum pseudo-capsicum

Sison amomum

Anacurdium orientale

\} Arbutus andrachne

Anemone hortensis

Anemone silvestris

Bromelia ananas

Angelica archangelica

* Aloe perfoliata has many varieties; which see in Aiton's Hortus Kewensis ;which Donn, in his catalogue of plants, called Hortus Cantabrigiensis, makes different species. Perfoliata means when the stem or stalk grows through the leaf.

+ Angelica is in high esteem in Lapland, they devour it with much avidity as a great delicacy; they eat leaves, stalks, and roots, either raw, or boiled in milk.-It is deemed a very great antiscorbutic, and carminative.

Acerbi's Travels in Lapland, printed in $\mathbf{3 8 0 2 .}$ 
Angelica, berry-bearing Angelica tree

Angelica, wild; or goutwort

Anise

Anise tree of China

Anotta; or annatto

Apeiba of the Basilians

Apple

Apple, Adam's ; or orange

Apple, bitter; or coloquintida Apple, blad; or W.Indian gooseberry

Apple, jamboo

Apple, custard

Apple, love*

Apple, love, of the antients

Apple, mad

Apple, male balsam

Apple, May ; or duck's foot

Apple, pine; or ananas

Apple, purple

Apple, soap

Apple, sour

Apple, star

Apple, sugar

Apple, sweet

Apple, thorn; or stramonium

Apple, water

Apricot

Arbor vitæ, American

Arbor vitæ, China

Arbor tristis; or sorrowful tree

Arbutus, upright

Arbutus, trailing

Archil; or orchilla
Aralia racemosa

Aralia spinosa

Agopodium padagraria

Pimpinella anisum

Illicium anisatum

Bixa orellana

Sloanea

Pyrus malus

Citrus aurantium

Cucumis colocynthis

Cactus pereskia

Eugenia jambos

Annona reticulata

Solanum lycopersicum

Atropa mandrágora

Solanum insanum

Momordica balsamina

Podophyllum peltatum

Bromelia ananas

Annona asiatica

Sapindus saponaria

Annona muricata

Chrysophyllum cainito

Annona africana

Annona squamosa

Datura stramonium

Annona palustris

Prunus armeniaca

Thuia occidentalis

Thuia orientalis

Nyctanthes arbor tristis

Arbutus unedo

Arbutus uva ursi

Lichen roccella

* At Sidney, in New Holland, they brewed beer from India corn, properly malted, and bittered with the leaves and stalks of the love-apple (solanum lycopersicum), or, as it was commonly called in the settlement, the Cane gooseberry; which was found to succeed very well. Collins's Account of N.S.Wales, 2d.ed. 1804, p. 334.

+ Prunus armeniaca, a supposed native of Armenia. 
Archangel; or dead nettle Archangel, yellow Aria theophrasti; or white beam Arnotta; or anotta Arrow-head Arrow-headed grass

Arrow-root, Indian

Arse-smart; or water pepper Arse-smart, spotted; or persicaria Artichoke Artichoke, Jerusalem Arum, African Arum, great Egyptian Arum, floating Asarabacca, common; or wild? spikenard

Ash, common

Ash, mountain; or wicken, or ? roan tree

Ash, poison; or varnish tree Ash, sweet or ground; or goutwort Egopodium podagraria Asparagus, common. Asparagus, climbing Asp, or aspen tree Asphodel, yellow; or king's-spear Asphodel, African low Asphodel, Scottish Aster; or starwort Aster, China Avens; or herb bennet Avocado; or alligator pear Auricula ; or bear's ear Auricula, borage-leaved Auricula-tree Awlwort ; or rough-leaved alysson Subularia aquatica Azarole service tree Azerita

Lamium album Galeopsis galeóbdolon Cratcogus aria Bixa orellána Sagittaria Triglochin palustre $\{$ Thalia geniculata $\{$ Maranta arundinacea Polygonum hydropiper Polygonum persicaria Cynara scolymus Helianthus tuberosus Calla Ethiopica Arum colocasia Orontium aquaticum \} Asarum europaum Fraxinus excelsior Sorbus aucuparia Rhus vernix Asparagus officinalis Medeola aspáragoídes Populus tremula Asphodelus luteus Anthericum asphódeloides Anthericum calyculatum Aster Aster chinensis Geum urbanum Laurus persea Primula auricula Verbascum mycomi Asclepias gigantea Cratcegus azárolus Prunus B

Bachelor's button campion
Lychnis dioica

Lychnis dioica 
Balm of Gilead

Balm of Gilead, false

Balsam, common garden

Balsam copaibi

Balsam of Canada

Balsam of Mecca

Balsam, nettle

Balsam of Peru

Balsam of Tolu

Balsam tree, succulent-leaved

Balsam tree

Balsamine, female ; or immortal eagle flower

Balsamine, yellow; or noli me tangere

Bambu cane

Banana ; or the forbidden fruit

Bane-berries; or herb christopher Banian tree

Bardana ; or burdock

Barilla-see Soda

Bark, true Jesuit's, or Peruvian

Bark, false Jesuit's

Bark of Elutheria; or cascarilla

Bark, angustura

Bark, Winter's

Bark, quercitron

Barley, common spring

Barren-wort

Basil

Basil, common field

Basil, American field

Basil, Syrian field

Basil, stone

Basil, wild; or mother of thyme

Batata ; or Spanish potatoe

Balm, common

Balm, Moldavian; or Turkey
Amyris gileadensis

Dracocephalum canariens?

Impatiens balsamina

Copaifera officinalis

Pinus balsamea

Amyris opobalsamum

Melittis melissophyllum

Myroxylon peruiferum

Toluifera bálsamum

Clusia flavia

Pistacia

Impatiens balsamina

Impatiens noli me tangere

Arundo bambos

IMusa sapientum

Actaa spicata

Ficus religioso

Arctium lappa

Cinchóna officinalis*

Iva frutesiens

Croton cascarilla

Brucea antidysentérico

- Wintera aromatica

Quercus nigra

Hordeum vulgare

Epimedium alpinum

Ocymum basilicum

Clinopodium vulgare

Monarda clinopodia

Ziziphora tenuior

Thymus áeinos

Thymus serpillum

Convolvulus batatas

Melissa officinalis

Dracocephalum moldúvica

* A root hath lately been discovered in Peru, called radix rhat-anguia, or radix rhatanio, and is said to be superior in all cases to the cinchona; but the generic character seems not yet to be known. 
Balm, Molucca

Balm, Indian ; or Oswego tea Bay tree, common; or laurel of
the antients

Bay, Loblolly

Bay, dwarf; or spurge laurel

Bay, sweet-flowering

Bead tree

Beam, white; or aria theophrasti

Bean

Bean, kidney, of India ; or soy

Bean, kidney, or French

Bean, scarlet kidney

Bean tree, kidney

Bean tree of America

Bean, caper

Bean,Egyptian; or peltated water lily

Bean trefoil-tree

Bean trefoil-tree, stinking

Bear-berries ; or uva ursi

Bear-bind

Bear's breech

Bear's ear ; or auricula

Bear's ear sanicle

Bear's paw

Bear's foot ; or setter-wort

Beard, man's

Beard, old man's; or traveller's joy

Beech wheat

Beech, common

Beech, purple-leaved

Beet, common

Bee-flower

Behen, white ; or spatling poppy

Bell flower

Bell, Canterbury

Bell pepper

Bells, hare
Moluccella

Monarda didyma

Laurus nobilis

Gordonia lasianthus

Dapline lanreola

Magnolia giauca

Melia azédarach

Cratogus aria

Vicia faba

Dolichos soja

Phaseolus vulgaris

Phaseolus coccineus

Glycine frutescens

Erythrina carnea.

Zygophyllum fabágo

Nymphaa nelumbo

Cytisus laburnum

Anagyris foctida Arbutus uva ursi

Convolvulus sepium

Acanthus

Primula auricula

Corlusa

Arctopus echinatus

Helleborus fatidus

Andropngon

Clematis vitalba

Polygonum frgopyrum*

Fagus silvatica

Fagus silvatica(purpurea)

Beta vulgaris

Ophrys

Cucubalus behen

Campanuia

Campanula medium

Cripsicum

Hyacinthus non-scriptus

* Phagos is greek for the beech, and puros is greek for wheat; it is called beech wheat from the similarity of the seed. See wheat, buck. 
Bella-donna; or deadly nightshade Atropa belladonna Belvidere; or Summer cypress Chenopodium scoparia Belly-ache weed Jatropa gossypifolia

Ben-see Behen

$\left.\begin{array}{l}\text { Berberry; common*; or pipe- } \\ \text { ridge bush }\end{array}\right\}$ Berberis vulgaris

Bergamot, oil of

Bermudiana

Betle

Betony

Betony, Paul's

Betony, water

Big barley

Bilberry $t$; or whortle berry, blue

Bilberry, red

Bindweed, great

Bindweed, black

Bindweed, rough

Bindweed, small gravel

Birch

Birch of Jamaica

Citrust

Bird cherry ; or cherry laurel

Bird's eye

Bird's foot

Birn's foot trefoil; or lamb-toes

Bird's foot trefoil

Bird's-nest

Bird's-nest, purple

Birth-wort

Bishop's weed, common

Bistort ; or adder's wort

Sisyrinchium hermudianum

Piper betle

Betonica officinalis

Veronica officinalis

Scrophularia betonicifolia

Hordeum hexastichon

Vaccinium myrtillus

Vaccinium vitis idcea

Convolvulus sepium

Polygonum convolvulus

Smilax aspera

Convolvulus arvensis

Betula alba

Pistacia

Prunus lauro-cerasus

Primula farinosa

Ornithopus

Lotus ornithopodivides

Trifolium ornithopodioides

Ophrys nidus avis

Orchis abortiva

Aristolochia

Ammi majus

Polygonum bistorta

* Sir Joseph Banks in his account of the disease in corn, called by farmers the blight, the mildew, and the rust, is of opinion that they are owing to a fungus; and says, if a berberry lush is near a field of corn, it may infect the whole; for as that shrub is subject to a kind of rust resembling the blight, the farina of its fungus may be carried by the wind to the pores of the corn.

Printed in 1805.

+ See note to citrus.

¥ It is said the bilberry is frequently used on the Continent for colouring white wines, which, with the help of a little alum to give a roughness, make them pass for red port wines. The stamina of this shrub form a very beautiful dome. 


\section{Bistort, small}

Polygonum viviparum

Bittel-sweet; or woody nightshade Solanum dulcamara

Bitter-wort

Blackberry; or bramble

Bladder-wort; or water milfoil

Blattaria ; or moth mullein

Blind man's ball; or puff ball

Blinks

Blite; or strawberry spinach

Blite, amaranth

Blood-flower; twy-blade; or African tulip

Blood-wood; or logwood

Blood-wort

Blue bottle; or blue bonnet; or? Cyanus

Blue bottle, mountain perennial

Bogbane; or marsh trefoil

Bogberry; or bogwort; or cranberry

Bohon upas-see Upas

Gentiana

Rubus fruticosus

Utricularia vulgaris

Verbascum blattaria

Lycoperdon bovista

Montia fontana

Blitum capitatum

Amaranthus blitum

\}Hemanthus coccineus

$\left\{\begin{array}{c}\text { Hamatoxylon campechio- } \\ \text { num }\end{array}\right.$

Rumex sanguineus

Centaurea cyanus

Centaurea montana Menyanthes trifoliata

\}Vaccinium oxycoccos

Bonny of Carolina; or oily grain Sesamum orientale

Borecole (a variety)

Borage, common

Box

Box, African

Box, low

Boxthorn, willow-leaved

Boxthorn, American

$\{$ Brassica oleracea (sabel-

Borago officinalis

Buxus sempervirens

Myrsine Africana

Polygala chamebuxus

Lycium barbarum

Randia aculeata

Bracken; or brakes; or common fern Pteris aquilina

Bramble; or blackberry

Brank; or beech wheat

Brank ursine; orCorinthian acanthus

Brasil ; or fernambuck

Brasiletto tree

Bread fruit, Otaheite

Bread fruit, Nicobar

Rubus fruticosus

Polygonum fagopyrum

Bread, or plantain tree; or banana Musa sapientum

Bread-nut tree, Jamaica

Brosimum alicastrum

Pterocarpus

Casalpinia

Artocarpus incisa

Pandanus leram 
Break-stone; or saxifrage

Saxifraga

Break-stone parsley; or parsley piert Aphanes arvensis

Briar, sw eet

Rosa rubiginosa

Briar, hep; or dog rose

$\left.\begin{array}{c}\text { Briget in her bravery; or scarlet } \\ \text { lychnis; or knight's cross }\end{array}\right\}$ Lychnis chalcedonica

Brimstone, or sulphur wort; or $\}$ Peucedanum officinale
hog's feunel

Brocoli (a variety)

Brooklime; or water speedwell

Broom, common besom $\uparrow$

Broom, white Spanish

Broom, African

Broom, dyer's; or greenwood; $\}$ Genista tinctoria
or wood waxen

Broom, arrow-shape jointed Génista sagittalis

Binom, rape Orobanche

Bruon, rape, with great purple
fowers

Bruise-wort; or soap-wort

Biyony, white

Bryony, black

Brickbean-see Bogbane

Buck's hom, plantain

Buck's hom, warted

Buckthorn, common

Buckthorn, sea (willow-leaved)

Buck-wheat-see Beech wheat

Buckee, Hottentot

Bug-bane

Bugle, common

Bugloss
Brassica oleracea (italica)

Veronica beccabunga*

Spartium scopariuin

Spartium monospermum

Aspalathus

Saponaria officinalis

Bryonia alba

Tamus communis

Plantago coronopifólia

Cochlearia

Rhamnus catharticus

Hippophe rhamnoides.

Diosma

Cimicifuga fatida

Ajuga reptans

Anchusa

Bugloss, broad-leaved, evergreen Anchusa sempervirens

Bugloss, small wild

Bugloss, small wild; or great? $\left.\begin{array}{l}\text { goose grass; or German } \\ \text { madwort }\end{array}\right\}$ Asperugo procumbens

Lycopsis arvensis

* Beccabunga seems a harsh specific name, but was formerly the name of the plant; it is derived from the Flemish becc-pungen (mouth smart), from its pun.
gent quality.

+ At Ghent, Antwerp, \&c, the flower buds of common broom are pickled as expers. 
Bugloss, viper's, common Bullace tree, W.Indian Bullace tree

Burdock ; or bardana* Burdock, lesser British Bur marigold

Burnet, garden, or common Burnet, greater wild Burnet saxifrage Burning thorny plant Bur reed, great Butcher's broom; or knee holly Butter bur

Butter-cup ; golden-cup; or crow-foot, corn
Echium vulgare

Chrysophyiluin glabrum

Prunus insititia

Arctium lappa

Xanthium sirumarizm

Bidens frondosa

Poterium sanguisorba

Sanguisurba officinalis

Pimpinella saxifraga

Euphorbia officinarum

Sparganium erectum

Ruscus aculeatus

Tussilago petasites

TRanunculus arvensis

Butter-wort; or Yorkshire sanicle Pinguicula vulgaris

Button tree

Button weed

Button wood

Button, bachelor's
Conocarpus erecta

Spermacose

Cephalanthus occidentalis

Lychnis dioica

C

Cabbage, dog's ; or dog's mercury

Cabbage, sea; or sea kale

Cabbage, savoy

Cabbage, red

Cabbage, turnep-rooted

Cabbage-bark tree

Cabbage-bark tree, base

\section{Cabbage, common}

Cabbage tree; or Palinetto roy- ? al; or lance-wood

Cabbage tree, W. Indian

Brassica oleracea

Theligonun cynocrambe

Crambe maritima

Brassicuoleracra (sabauda

Brassica oleracea (rubra)

$\{$ Brassica oleracea (napobrassica)

Geoffroya spinosa

Geoffroya inermis

Corypha unbraculifera Areca oleveresa

Cacao; or cocoa; or chocolate nut Thenbrina crecao

* The bardana, which acquired so much celebrity by the late Dr Hill, for the cure of the gout, and the sort he preferred, was the wool y-hicaded hrolock, being 2. variety from arctium lappa, the common burdock 
Calabash; or gourd

Calabash ; or gourd tree

Calumba ; or lignum aloes

Calamint, common

Calamint; or balm cat-mint

Calamint, water

Calamus aromaticus; or sweet?

Caltrops flag, or rush

Caltrops, water

Calves' snout; or toad flax

Cameoclits-see Quamoclits

Cammock; or petty whin; or rest harrow

Campeachy wood; or logwood

Camphor tree

Campion, rose ; or wild lychnis

Campion

Campion, viscous ; or catchfly

Candle of the Indians

Candia lion's foot

Candy-tuft

Candy-tuft, perennial

Candy-tuft tree

Cane, bambu; or walking cane

Cane, or shot, Indian

Cane, or reed

Cane, sugar

Canella alba tree; or white cinamon Canella alba

Caper bush, common

Carat, or caract tree

Caraway ; or carui

Carduus benedictus

Cardoon

Cardinal flower; or water gladiole Lobelia cardinalis

Carica

Carnation; or clove July flower. Dianthus caryophyllus

Carnation, Spanish ; or flower fence P'oinciana pulcherrima

Carnation tree; or foreign colt'sfoot

Carob tree; or St. Jolnn's bread
Ficus carica

Cucurlita

Cresctntia cucurbitina

Excoecaria agallocha

Melissa calumintha

Melissa nepela

Mentha gentilis

Tribulus

$\left\{H_{c}\right.$ matoxylon campechia-

Laurus camphora

Agrostemma coronaria

Lychnis

Silene muscipula

Rhizophora candel

Catarianche lutea

Iberis umbellata

Iberis sempervirens

Iberis semperflorens

Arundo hambos

Canna indica

Arundo

Saccharum officinarum

Capparis spinosa

Ceratonia siliqua

Carum carui

Cnicus acarna

Cynara cardurculus

Dianthus caryophyllus

Cacalia kleinia

Ceratonia siliqua
Acorus calamus

Trapa natans

Antirrhinum linaria 
Carrot, wild

Carrot, garden

Carrot, candy*

Carrot, deadly; or scorching fennel Thapsia villosa

Carui ; or caraway

Cascarilla; or bark of Eleutberia

Cashew nut; or acajou

Cassada ; or cassava ; or manihot Jutropha manihot

Cassina ; or yapon

Cassia lignea

Cassia, poet's

Cassia of the shops

Cassidony; or French lavender

Cassio-berry bush

Catechu; or terra japonica

Catalpa

Catchtly, or fly-trap

Catchtly

Catchfly, dog's-bane

Catchfly, lobels

Catchfly; or viscous campion

Catmint; or nep

Catmint, or calamint, wild

Cat's-foot; or ground ivy

Cat's-eye

Cat's-foot

Cats-tail ; or reed mace

Caterpillars; or scorpion grass Caulitlower, or cole flower (a
variety)

Cedar, red Virginian

Cedar of Jamaica, base

Cedar, white

Cedar of Bermudas

Cedar of Busaco in Portugal

Cedar of Libanus

Celandine, common or greater
Daucus sylvestris

Daucus carota Athamanta cretensis

Carum carui

Croton cascarilla Anacardium occidentale

Cassine paragua

Jaurus cassia

Osyris alba

Cassia fistula

Lavandula stichas

Viburnum lavigatum

Mimosa catechu.

Bignonia catalpa

Dionce muscipula

Silene muscipula

$\left\{\begin{array}{c}\text { Apocymum androsamifo- } \\ \text { lium }\end{array}\right.$

Silene armeria

Lychnis viscaria

Nepeta cataria

Melissa nepeta

Glechoma hederacea

Gnaphalium occulus cati

Gnaphalium dioicum

Iypha latifolia

Scorpiurus vermiculata

Brassica oleracea (botrytis)

Juniperus Virginiana

Theobroma guazuma

Cupressus thyoides

Juniperus bermudiana

Cupressus pendula

Pinus cedrus

Chelidonium majus

* The seeds of candy carrot are said, by Dr. Brook, to be used in making $V_{e}$ nice treacle and mithridate. 
Celandine, cut-leaved (a variety) Chelidoním majus

Celandine, lesser; or pile-wort

Celandine tree

Kamunculus ficaría

Celery-see Selery

Cereus, common creeping ten angled

Centaury

Centaury without stems

Centaury, lesser

Centaury, yellow perfoliate

Ceterach

Chamæmile, common

Chanzemile, field

Chamæmile, dwarf, or sea

Bocconia frutescens

Champignon; or esculent mush-? room

Char ; or sedge

\} Cactus cereus flageliformis

Centaurea

Centaurea crocodilium

Gentiana centuuríma

Chlora perfoliata

Asplenium ceierach

Anthenis nobilis

Anthemis arvinsis

Matricaria chamamilla Charity; Greek valerian; or Ja-
cob's ladder

Charlock; or ketlock

Charlock, white-flowered, with jointed pods

Chaste tree; or agnus castus

Chay root; or E. India madder

Sinapis arvensis

Raphanus raphanistrum

Vitex agnus-castus

Cheese rennet; or ladies' bed straw Galium verum

Cherry tree

Cherry, Barbadoes

Cherry, bird

Cherry, black

Prunus cerasus

Malpighia glabra

Prunus avium

Cherry laurel, or common laurel

Cherry, cornelian

Prumus cerasus nigra

Cherry, dwarf; or uprighthoney-

suckle
Cherry, Hottentot; or Cape phil- $\}$ lyrea

Cherry, Winter common

Cherry, Alpine

Chervil, garden

Prunus lauro-cerasus

Cornus mascula

Lonicera carulea

Cassine maurocenia

Physalis alkehengi

Innicera alpigena

Soandix charefolium

* Chamnemile is generally spelt chamomile, but as it is derived from the Greet ord chamai (humi crescens), it ought to be chamamile. - See note to may-werd. 
Chervil, or cicely, wild; or cow parsley

Chestnut

Chestout, dwarf American; or chinquapin

Chestnut, horse

Chestnut, scarlet horse

Chestnut, Indian rose

Chiches; or Chich pea; or garavances

Chichling-vetch

Chickweed, common

Chickweed, African

Chickweed, berry-bearing

Chickweed, great; or stitchwort

Chickweed, mountain

Chickweed, mouse ear

Chickweed, sea

Chickweed, small water

China root

China root, false

China rose

Charophyllum sylvestre

Fagus castanea

Fagus pumila

Esculus hippo-castanum

Esculus paria

Mesua ferrea

Cicer arietinum

Lathyrus cicera Alsine media

Mollugo verticillata

Cucubalus baccifera

Stellera holostea

Moehringia muscose

Cerastium dichotomum

Arenaria peplöídes

Montia fontana

Smilax china

Senecio pseudo-china

Hibiscus rosa-sinensis

$\left.\begin{array}{c}\text { Chinquapin ; or dwarf American } \\ \text { chestnut }\end{array}\right\}$ Fagus pumila

Chirimoya; or sweet sop

Chocolate nut; or cacao

Annona squamosa

Theobroma cacao

Christmas rose; or black hellebore Helleborus niger

Christopher, common herb

Christ's thorn*

Actaa spicata

Rhamnus paliurus

Chrysanthemum, base

Chrysanthemum, hard-seeded

Ciboules; or Welsh onion

Cichory $\uparrow$

Silphium asteriscus

Osteospermum

Allium cepa (cambrica)

Cichorium intybus

* Carist's thorn (rhamnus paliurus) is so called from a supposition that his crow -f thorns was made from this shrub, which is very common in Judea.

+ It is said, in the Monthly Magazine for May, 1809 , that in many parts of Germany and Holland, they adulterate their coffee, by mixing therewith cictiony root (cichorium intybus) dried and ground, which renders it of higher colour, and stronger flavour; for which purpose the wild kind is said to be the best. - The French use the roots of dandelion. 
Cichory, yellow; or base hawkweed Picris hieracioides

Cichory, gum

Cichory, wart; or zacintha

Cicuta; or water hemlock

Cicely; or fool's parsiey

Cicely, sweet; myrrhis; or wild ? myrrh

Cicely, or chervil, wild

Cinnamon tree

Cinnamon, white or wild

Cinnamon, base

Cinquefoil

Cinquefoil, marsh

Cinquefoil, shrub

Cistus, gum; or rock rose

Cistus, marsh; or wild rosmary

Cistus, lesser marsh; or base heath Andromeda polifolia

Cistus, rape of

Cistus, nettle-leaved

Cistus, dwarf; or little sunflower

Citron

Citrul; or water melon

Cives; or chives

Clary

Clary, purple-topped-see Sage

Clary, Pyrænean

Clivers; goosegrass; or hairiff

Cloud-berry

Clove July flower

Clove tree

Clover, common

Clover, English red; or cow-grass

Clover, white; or honeysuckle ?

grass

Cobweb aloe

Cobweb sedum

Cocculus indicus (India berry)

Cochinil fig; or nopal

Cockscomb; rattle; or lousewort

Cockscomb amaranth

Cockscomb; or yellow rattle

Cockshead; or saintfoin
Chondritla jumeer

Lapsaria zerintha

Cicate vrrosa

Dithasa cynapium

Scandix odorata

Cherophyllum sylzestre

Lauries cimamomum

Canclla alba

Laurus cassia

Potintilla

Comarum polustre

Potentilla fruticosa

Cistus ladaniforus

Ledum palustre

Cytinus hypocistis

Turnera cistoides

Cistus helianthemum

Citrus medica

Cucurbita citrullus

Allium schenoprasum

Salvia sclarea

Horminum pyrenaicum

Galium aperine

Rubus chamcemorus

Dianthus caryophyllus

Caryophyllus aromaticus

Trifiolium pratense

Irifolium alpestre

Trifolium repens

Aloe pumila arachnoides

Sempervioum arachnoideuns

Menispermum cocculus

Cactus cochinillifer

Pedicularis palustris

Celosia cristata

Rhinanthus crista-galli

Hedysarum onobrychis 
Cockle; or popple

Coco nut palm

Cocoa plum

Codlings and cream

Colfee, Arabian

Coffee, W. Indian

Colewort, rape, \&c.

Colewort, sea

Agrostemma githago

Cocos nucifera

Chrysobalanus icaco

Epilobium hirsutum

Coffea arabica

Coffea occidentalis

Brassica napus

Crambe maritima

Colewort, sea

Convolvulus soldanella

Colocasia; or great Egyptian arum Arum colocasia

Coloquintida; or bitter apple

Colt's-foot, common.

Colt's-foot, Alpine

Cucumis colocinthis

Tussilago farfara

Colt's-foot, foreign ; or cabbage, or carnation tree

Columbine, common

Columbine,feathered; ormeadow rue

Cacalia suaveolens

Comfrey, common; or consound* greater

Consound, middle; or bugle

Consound, lesser; or self-heal

Consound, least; or daisy

Consound, red

Cacalia kleinia

Aquilegia vulgaris

Thalictrum aquilegifolium

Consound, Saracen's; or wound- ?

wort

Consound, true Saracen's

Consound, marsh

Consound, royal

Consound, golden

Contrayerva

Contrayerva of Hermandes

Convolvulus; or bindweed

Convolvulus, scarlet

Convolvulus major

Coral tree; or dog-wood of Jamaica Erythrina corallodendrum

Coral-wort ; or tooth-wort

Senecio sarracénicus

Comarum palustre

Delphinium consolida

Cistus ladaniferus

Dorstenia contrayerva

Passiflora

Convolvulus.

Ipomoea coccinea

Convolvulus purpureus
Symphytum officinale

Ajuga reptans

Prunella vulgaris

Bellis perennis

Tormentilla erecta

Solidago virgo aurea 
Coriander

Cork tree

Corn-bind; or devil's-gut

Corn, Guinea; or Indian millet

Corn, Indian ; or maze

Corn Alag; or gladiole, common

Corn marigold; or guills

Corn poppy

Corn salad; or lamb's lettuce

Cornel; or dog berry

Cornelian cherry

Costmary ; or alecost*

Coronopus; or swine's cress

Cotton plant, + common Levant

Cotton tree

Colton, lavender, common

Cotton tree, silk

Cotton grass, common

Cotton weed; or cudweed

Courbaril ; or locust tree

Cow-grass; or English red clover Trifolium alpestre

Cow-quakes; or quake grass

Cow-itch; or cowage

Cowslip (a variety)

Cowslip, American; or meadia

Cowslip; or sage of Jerusalem; or spotted lungwort

Cow-weed ; or wild chervil

Crab tree; or apple tree

Crab, small Siberian
Coriandrum sativum

$\{$ Quercus suber

$\{$ Spondias mombin

Convolvulus arvensis

Holcus sorghum

Zea mays

Gladiolus communis

Chrysanthemum segetum

Papaver rhoeas

Valeriana locusta

Cornus sanguinea

Cornus mascula

Tanacetum balsamita

Cochlearia coronopus

Gossypium herbaceum

Gossypium arboreum

Santolina chamo cyparissus

Bombax gossypinum

Eriophorum polystachion

Gnaphalium margaritaceum

Briza

Dolichos pruriens

Primula veris (officinalis)

Dodecatheon meadia

Y Pulmonaria officinalis

Chorophyllum sylvestre

Pyrus malus

Pyrus malus baccata.

* Costmary, formerly called costus marice, receives its name from its aromatic quality, similar to the costus arabicus; it is also sometimes called alecost, from the pleasant flavour it gives to that liquor by infusion;-and it is said that the essential oil is of great use in France, to cure all wounds and bruises.

+ Beside the herbaceous and arboreous cotton (which see under gossypium), there is also an animal cotton, which is spun by a worm (in the same manner as silkworms) known in America by the name of manioc, or indigo worm, and encloses itself in a white cotton ball; which is said to have many advantages over the vegetable cotton.

Edin. Rev. vol, iii. p. 89, printed in 1806 . 
Crackling, or sandbox tree*

Crake, or crow berries; or black

Cranberry

Crane's bill

Hura crepitans

Creeper, or ivy, Virginian; or five-leaved Canada vine

Cress, garden

Cress, Virginian, or Indian

Cress, Indian ; or nasturtion

Cress, Sciatica

Cress, Spanish

Empetrum nigrum

Vaccinium oxycoccos

Geranium

Cress, swine's

Cress, wall ; or tower mustard

Cress, warted

Cress, water

Hedera quinquefolia

Lepidium sativum

Lepidium virginicum

Tropacolum majus

Iberis nudicaulis

$V e l l a$ апnиa

Cochlearia coronopus

Turritis

Cochlearia

Cress, winter

Sisymbrium nasturtium

Erysimum barbarea

Cross, St. Andrew's

Cross, Jerusalem; or knight's cross; or scarlet cross; or flower of Constantinople $\}$

Crosswort ; or mug-weed

Crocus; or saffron

Ascyrum crux-andrea

Crocus, common yellow spring Crocus sativus vernus

Crow, or crake berries; or black- ? berried heath

Crow-foot; golden cup; or but- $\}$ Ranunculus arvensis
ter cup, corn

Crow-foot, geranium

Crow-sike

Geranium pratense

Crown imperial

Cubebs

Conferva rivularis

Cuckow flower; or lady's smock Cardamine pratensis

Cuckow flower; or ragged robin Lychnis flos cuculi

Cuckow pink; or wake robin

Cucumber

Fritillaria imperialis

Piper cubeba

Cucumber, asses, spurting, or wild Momordica elatérium

- Crackling or sandbox tree, so called from the capsules bursting with a loud explosion; and being large and woody, consisting of many cells, are used as sandboxes. 
Cucumber, Egyptian

Cucumber, serpent

Cucumber, single-seeded

Cucumber, small creeping

Cudweed; or cotton weed

Cudweed,common; or herbin

Cudweed, base

Cullions (round roots)

Cullions, soldier's

Cumin

Cumin, base or wild

Currant ; or Corinth*

Currant; $\dagger$ or Corinth, foreign ? dried (a variety)

$\begin{aligned} & \text { Currant-leaved Virginian gelder } \\ & \text { rose }\end{aligned}$
Spirca opulifolia

Curry, Indian

Cussion, lady's

Cussion, sea; sea pink; or thrift

Cypress, common upright

Cypress, summer; or belvedere

Cyclamen, common; or sow bread

Cyanus; or blue bottle

Cytisus secundus clutii ; or Italian cytisus

D

Daffodil
Mangifera indica

Saxifraga hypnoides

Statice armeria

Cupressus sempervirens

Chenopodium scoparia

Orchis pyramidalis

Cuminum cymímum

Lagœiia cuminö́des

Ribes

Vitis vinifera (corinthiaca

Momordica luffa

Irichosanthes anguina

Melothria pendula

Gnaphalium margaritaceum

Micropus supinus

Orchis

Cyclamen europreum

Centaurea cyanus

Cytisus sessilifolius

Daffodil, sea; or lesser white squill Pancratium maritimum

Daisy, common or least

Daisy, blue globe

Bellis perennis

Daisy, hen and chicken

Daisy, greater; or ox eye

Globularia alypum

Bellis perennis prolifera

$\{$ Chrysanthemum leucanthe-

* In Brook's History of the Island of St. Helena, printed in 1808, p. 18, it is said that the gooseberry and currant bushes turn to evergreens, and do not bear fruit.

+ This currant is the staple commodity of Zante; the annual export of which amounts; on an average, to $8,000,000$ lbs. Cephalonia and the Morea jointly furnish about the same quantity; the greater part of which is said to be consumed in Great Britain. 
Daisy, middle

Daisy, Michaelmas; or aster

Damson tree (a variety)

Damson tree, W. Indian
Doronicum bellidiastrum Aster

Prunus domestica

Chrysophyllum glabrum

Dandelion,or dent-de-lion,common Leontodon taraxacum

Dane-wort; wall-wort; or dwarf ? elder

Darnel; or rye grass

Darnel, annual

\} Sambucus ebulus

Lolium perenne

Date, or dactyl tree ;* or greater palm

Lolium temulentum

Devil in a bush; or fennel flower

Devil's-bit

Devil's-bit, yellow

Devil's-gut; or cornbind

Dewberry bush

Dyer's weed ; or wild woad

Dyer's weed; or dyer's broom

Dill

Dittander; or pepper-wort

Dittany, white; or fraxinella

Dittany of Crete $\uparrow$

Dittany, base

Dock

Phonix dactylifera

Nigella damascena

Scabiosa succisa

Leontodon autumnale

Convolvulus arvensis

Rubus casius.

Rescda lutenla

Genista tinctoria

Anethum graveolens

Lepidium latifolium

Dictamnus albus

Origanum dictamnus

$\left\{\begin{array}{c}\text { Marrubium pseudodictam- } \\ \text { nus }\end{array}\right.$

Rumex

Dr. Tinker's weed; or fever root;

or false ipecacuana

Triosteum perfoliatum

* The Africans have a superstitious tradition, that when the Virgin Mary was in travail, it was near a date tree; and when in pain, she exclaimed " $O$ that $I$ had some dates!" and immediately the letter $\mathrm{O}$ became marked on the stone of the fruit.-It seems all date-stones have a circular mark on them, like the letter $\mathrm{O}$.

+ No plant hath been so highly extolled by the antients, as the dittany of Crete ; viz. by Theophrastus, Hippocrates, Plutarch, Cicero, Dioscorides, \&c. It is peculiar to the island of Crete (now Candia), and is not found native in any other country; and the inhabitants at present apply it with success on many occasions. An infusion of the dried leaf with a little sugar, yields a liquor more pleasing to the palate, and more finely flavoured than tea. It immediately removes languor of the stomach, and restores it after digestion.

Letters on Greece by M. Savary, printed 1788 .

Virgil celebrates this plant as a vulnerary, and gives a particular description of it under the name dictamnus, called so from its growing on Mount Dicte, as on Mount Ida; both being in the island of Crete.

En. xii, 1. 411. 
Dodder, * European

Dodder of thyme

Dog's-bane

Dog's-bane, base
Cuscuta europaca

Cuscuta epithymum Apocynum

$\{$ Cynanchum

$\{$ Asclepias syriaca

Dog-wood; cornel; or gatter tree Cornus sanguinea

Dog-stones; or satyrion Orchis

Dogwood of Jamaica; or coral tree Erythrina corallodendrum

Dogwood tree; or fish bane Piscidia erythrina.

Dog's-tooth violet

Dorycnium of Montalier

Erythronium dens-canis

Dove's foot; or crow-foot geranium Geranium pratense

Doura; or Indian millet

Dragons

Dragons, spotted

Dragon's head

Dragon wort; or tarragon

Drauk; or corn broom grass

Dropwort; or filipendula

Dropwort, hemlock

Dropwort, water

Duck-meat

Duck-meat, starry ; or star grass

Duck's-foot; or May apple

Dulse

Dwale; or common deadly night-? shade

Durion

\}

Durio zibethinus
Holcus sorghum

Dracontium

Arum dracunculus

Dracocephalum Artemisia dracunculus

Bromus arvensis

Spircea filipendula

Oenanthe crocata

Oenanthe fistulosa

Lemna minor

Callitriche

Podophyllum peltatum

Fucus palmatus

Atropa belladonna
E

Ebeny

Ebeny wood, true

Ebeny, false

Ebeny of the Alps; or laburnum

Ebeny, mountain

Edders
Ebenus cretica

Diospyros ebenum

Poinciana pulcherrima

Cytisus laburnum

Bauhinia acuminata

Arum peregrinum

* Dodder (cuscuta) is a very singular plant, it takes root from seed like other plants; but soon perishes if it is not near some other plant to support it, around which it twines and entangles itself in a very complicated manner; the root then soon withers away, and it is supported by the plant around which it twines; hence called a parasitical plant : it has no leaves, - See cuscuta. 
Egg plant

Eglantine rose

Elder tree

Elder, dwarf ; or danewort

Elder, marsh

Elecampane; or yellow startwort

Elecampane, base

Elemi tree, gum

Elephant's foot

Elephant's head; cock's comb; or yellow rattle-grass

Elichrysum, base Ethiopian

Eller; or alder

Elm, common

Elm, witch (a variety with broad, er leaves)

Eleutheria-see Cascarilla

Endive

Eryngo; or sea holly

Eryngo, common

Eschalot; or shalot

Evergreen

Everlasting, or eternal flower

Everlasting; or globe amaranth

Euonymus,common; or spindle tree Euonymus europaus

Euonymus, base

Euonymus, base ; or staff tree

Eye-bright, common

Elaterium; or spurting cucumber Momordica elaterium

F

Fat hen; or wild orach

Featherfew-see Feverfuge

Felwort ; or gentian, yellow

Fennel

Fennel, horse
Solanum melong'ena

Rosa eglanteria

Sambucus nigra

Sambucus ebulus

Viburnum opulus

Helenium autumnale

Amyris elemifera

Elephantopus scaber

Rhinanthus christa galli

Stoebe athiopica

Betula alnus

Ulmus campestris

Ulmus campestris latifolia

Eryngium* maritimum

Eryngium campestre

Alitium ascalonicum

Aizoon

$\{$ Gnaphalium

Xeranthemum

Gomphrana

Kiggelaria africana

Celastrus

Euphrasia officinalis
Momordica elaterium

\section{Chenopodium viride}

Gentiana lutea

Ancthum foniculum

Seseli hippomarathrum
Cichorium endivia

* The flowers of eryngium grow in a head on a common receptacle, somevhat similar to the lurdock; and as they ripen, the stalks and head change to different colours, some to blue, others to purple, \&c, which make a beautiful appearance. 
Fennel, hog's; or sulphur wort Peucedanum officinale Fennel, scorching; or deadly carrot Thapsia villosa Fennel, sea; or samphire Crithmum maritimum

Fennel fower; or devil in a bush Nigella damascena Fennel flower of Crete Fenrel, giant

Fenugreek, common

Fernambuck; or Brasil Garidella nigellastrum Ferula

Trigonella fonum grocum

Pterocarpus

Fern, male; or polypody

Fern, female

Polypodium filix mas

Fern, flowering; or Osmund royal Osmunda regalis

Fern, common or true mule's

Fern, common; or bracken

Fern, mule's or moon; or mulewort

Fern, fork ; or acrostic

Fern, sweet

Feverfuge, common

Asplinium hemionitis

Pteris aquilina

\section{Hemionitis}

Acrostichum septentrionale

Scandix odorata

Matricaria parthenium

Feverfuge, base; or wild wormwood Parthenium hysterophorus

Fever root; Dr. Tinker's weed; or false ipecacuana

Fever weed

Fiddle dock

Fiddle wood

Triosteum perfoliatum

Ficoides

Eringium fatidum

Rumex pulcher

Citharexylon

Cacalia ficoides Ficoides, diamond; or ice plant $\left\{\begin{array}{c}\text { Mesembryanthemum cry- } \\ \text { stallinum }\end{array}\right.$

Fig marigold

Fig, common

Fig, Indian, common

Fig tree, Indian*

Fig, Bengal

Fig, Indian ; or prickly pear

Fig, infernal ; or prickly poppy

Fig, Pharaoh's; or true sycomore

Fig, Pharaoh's

Mesembryanthemum

Ficus carica

Cactus opuntia

Ficus indica

Ficus benghalensis

Cactus tuna

Argemone mexicana

Ficus sycomorus

Musa

* Ficus indica (Indian fig-tree) is a large tree rising with opposite branches on all sides, with long egged leaves; each branch emits a slender flexile depending appendage from its summit like a cord, which roots into the earth and rises again.

Sloan's Hist. of Jamaicu.

This seems the same tree as the ficus religiosa.-See note to ficus. 
fig, cochinil ; or nopal Figwort

Filbert nut

Filipendula; or dropwort

Fingrigo, prickly

Finochia; or Azorean fennel

Fir, spruce

Fir, silver

Fir, baim of Gilead

Fir-moss, upright

Fish-bane; or dogwood tree

Flags

Flag

Flag, African corn

Flag, yellow water

Flag, corn ; or gladiole, common

Flag, Persian corn

Flag, sweet; or calamus aromaticus Acorus calamus

Flammula jovis

Flax, or line, common

Flax, Carolina

Flax, toad

Flax, New Zealand

Flea-bane, greater

Flea-bane, lesser blue

Flea-bane, marsh

Flea-bane, middle

Flea-bane, shrubby African

Flea-wort

Flix-weed

Flower of Constantinople knight's cross, \&c.

Flower-gentle; or amaranth

Flower of an hour

Flower de luce

Flower-fence of Barbadoes; or

Spanish carnation

Flower-fence, base

Fluellin; or speedwell

Fly, dog's-bane catch

Fly-bane; or catch-lly

o $\mathrm{M}$
Cactus cochinillifer

Scrophularia

$\{$ Corylus avellana (alba; vel rubra

Spirca filipcudulas

Pisoniu aculeata

Anethum segitum

Pinus abies

Pinus picea

Pinus balsamea

Lycopodium selago

Piscidia erythrina

Alga

Iris

Antholiza

Iris pseudacorus

Gladiolus communis

Antholiza cunonia

Clematis fiamula

Linum usitatissimum

Polypremum procumbens

Antirrhinum linaria

Phormium tenax

Conyza squarrosa

Erigeron acre

Inula pulicaria

Inula dysenterica

Tarchonanthus

Plantago psyllium

Sisymbrium sophia

\}Lychnis chalcedonica

Amaranthus

Hibiscus trionum

Iris germanica

Poinciana pulcherrima Adenanthera pavonina Verurica Apocynum androsamifoliunt Silene muscipula 
Fly-trap; or catch-fly

Fly-eater

Fly, vegetable

Forbidden fruit; or banana Musa sapientum
Dionaa muscipuld

Arum muscivorum

Clavaria militaris

Musa sapientum

Foxglove

Digitalis purpurea

Frankincense; or incense-wort Gnaphalium odoratissimum

Frankincense tree; or Virginia three-leaved pine

Fraxinella; or white dittany

Fringe tree

Fritillary

Fritillary, cock's comb; African swallow-wort; or fritillaria crassa minor

Fritillaria crassa major

Frog's-bit

Friar's cowl

Fumuterræ, common

Furze; gorse ; or whin

Fustic treet

Fuz-ball; or puff-ball

Fungusse's

Pinus i $œ d a$

Dictamnus albus

Chionanthus virginica

Fritillaria

Stapelia variegata

Stapelia hirsuta

Hydrocharis morsus-rance

Arum arisarum

Fumaria officinalis

Ulex europous

Morus tinctoria

Lycoperdon bovista

Fungi

G

Gale; sweet gale; or Dutch myrtle Myrica gale

Galangale, larger

Galangale, lesser

Cyperus

Kampfaria galanga

Garavances, Spanish; or chich pea Cicer arietinum

Garlic

Garlic, crow or wild

Allium sativum

Garlic pear

Garlic, great round-headed; or

Turkey; or rocambole

Gatter tree; or dogwood

Gentian; or felwort, yellow

Gentian, base

Gentian, marsh ; or swertia

Gentianella

Allium vineale

Cratava tapia

Allium scorodoprasum

Cornus

Gentiana lutea

Sarothra gentianüides

Swertia perennis

Gentiana acaulis

* See Skinner's dict. +Fustic dyes a yellow. 
Gerard, herb; or goutwort Germander

Germander, rock

Gill; or ground ivy

Gilly flower--see July flower

Ginger, wild, of Arabia

Ginger

Ginseng; or ninzin

Gladiole; or corn flag, common

Gladiole, water

Gladiole, water; or flowering rush Butomus umbillutus

Gladiole, water; or cardinal tower Lobelia cardinalis

Gladwin, stinking

Glass-wort ; or kali

Glass-wort, jointed ; or kali

Glass-wort, berry-bearing

Globe daisy, blue

Globe flower

Globe, ranunculus

Goat's-beard, common

Groat's-beard, garden; or salsafy

Goat's-stones, greater

Goat's-stones, lesser

Goat's-thoin; or tragacanth

Gold of pleasure

Golden-cup; butter-cup ; or
crow-foot

Golden-rod; or woundwort

Goldylocks

Goldylocks

Goldylocks, African

Good Henry; all-good; or Eng- \} Chenopodium bonus Henlish garden mercury

Gooseberry

Gooseberry, American

Gooseberry, W. Indian; or blad $\}$ apple

Goose-foot ; or wild orach

Goosegrass; clivers; or hairiff
Aigopodium podagraria

Teucrium chamadrys

Veronica teucriam

Glechoma hederacea

Costus arabicus

Amornum zingiber

Panax quinquejolia

Gladiolus communis

Lobelia dortmanina

Iris futidissima

Salsoiu kali

Salicornia herbacea

Anabasis

Globularia alypum

Sphuranthus indicus

Trollius èropueus

Tragopogon pratense

Tragopogon porrifolium

Satyrium hircinum

Orchis

Astragalus tragacantha

Myagrum satioum

Ranunculus arvensis

Solidago virga-aurea

Chrysocoma comaaurea

Gnaphatium

Athanasia

\} ricus

Ribes grossularia

Melastoma grossularioides

Cactus perestia

Chenopodium viridé

Galium aperine

* See note to ranunculus. 
Goosegrass; or wild tansey Potentilla anserina

Goosegrass, great; small wild bu- ?

gloss; or German madwort $\}$ Asperugo procumbens

Goose tongue; or sneeze-wort Achillea pturnica

Go to bed at noon; or goat's beard Tragopogon pratense

Gorse; furze; or whin Ulex europous

Gourd; or calabash

Cucurbita

Gourd; or calabash tree Crescentia cucurbitina

Gourd, sour, of Ethiopia; or monkey's bread

Gourd, Jonah's

Gourd, buckler; or squash

Goutwort; or herb-gerard; or

wild angelica; or sweet ash $\}$ Egopodium podagraria

Grace, herb of ; or rue

Grain*-see wheat, barley, \&c.

Grains of Paradise

Grain, oily; or bonny

Grain, scarlet ; or kermes oak

Grain, scarlet; or cochinil

Granadilla

Grape, or vine tree

Grape-wort

Grape, sea; or shrubby horse-tail

Grape, sea-side; or mangrove

Grass, arrow-headed

Grass, brown-bent, or dog's

Grass, corn broom; or drauk

Grass, cat's-tail

Grass, cock's-foot

Grass, cow, or marl; or English red clover

Grass, canary

Ruta graveolens

Adansonia digitata

Cucurbita melopepo

Amomum granum Paradisi

Sesamum orientale

Quercus coccifera

Cactus cochinillifer

Passiflora maliformis

Vitis vinifera

Uvaria

Ephedra

Coccoloba uvifera

Triglochin

Agrostis canina

Bromus arvensis

Phleum pratense

Dactylis

Trifolium pratense

Phalaris canariencis

Grass, striped canary; or ribbon Phalaris arundinaceat

Grass, cotton

Grass, darnel, annual

Eriophorum polystachion

Lolium temulentum

* Grain, with respect to corn, ought to be spelled grane, as it is derived from the latin word granum; and it then will conform with the word granary, where cor
is deposited.

+ See note to phalaris. 
Grass, darnel; or rye, or ray grass Lolium perenne Grass, dog's; or couch; or quick; ? or twitch

Grass, dog's-tail

Grass, feather

Grass, fescue

Grass, fox-tail

Grass, fox-tail, of the Indies

Grass, hard

Grass, hair

Grass, hare's-tail

Grass, lyme

Grass, marl* - see Cow grass

Grass, mat

Grass, smooth-stalked meadow

Grass, rough-stalked meadow

Grass, millet

Grass, oat

Grass, panic

Grass of Parnassus

Grass, pepper

Grass, poley

Grass, purple

Grass, quake ; or cow-quakes

Grass, rope, or melic

Grass, rush

Grass, sedge ; or Cyperus grass

Grass, silk $\dagger$

Grass, star

Grass, sea

Grass, scorpion ; or caterpillars

Grass, scurvy

Grass, Timothy
Triticum repens

Cynosurus

Stipa pennata

Festuca

Alopecurus pratensis

Alopecurus indicus

Egilops

Aira

Lagurus ovatus

Elymus

Nardus stricia

Poa pratensis

Poa trivialis

Milium effusum

Aristida

Panicum miliaceum

Parnassia palustris

Pilularia globulifera

Lythrum

$\left\{\begin{array}{c}\text { Medicago polymorpha }(a= \\ \text { rabica })\end{array}\right.$

Briza

Melica

Schoenus

Carex divisa

Panicum sericeum

$\{$ Callitriche verna et autumnalis

Ruppia maritima

Scorpiurus vermiculata

Cochlearia officinalis

Phleum pratense

* Marl grass is much cultivated in some parts of Somersetshire; called so from its growing well on marly land.

+ Silk grass (panicum sericeum) may be spun as fine as silk, and is used for various purposes, but chiefly for ropes and fishing lines.-It grows in the island of Tobago.-See Universal Mag. for June, 1749. 
Grass, toad

Grass, vernal, sweet-scented

Grass, wrack

Grass, worm

Gravel-bind

Green-wood; or dyer's broom

Green-sauce; or sorrel

Grim the collier

Gromwel, common

Gromwel, German

Groundsel

Groundsel, common

Groundsel, Bolonian

Groundsel tree; or plowman's spikenard
Bufonia tenuifolia Anthoxanthum odoratum Zosiera marina

Spigelia anthelmia

Convolvulus

Genista tinctoria

Rumex acetosa

Hieracium aurantiacum

Lithospermum officinale

Stellera

Senecio

Senecio vulgaris

Erigeron boloniense

Baccharis halimifolia

Groundsel tree, with a ficoides leaf Cacalia ficoides

Guava; or guayava; or bay plum

Guills; or corn marigold

Gum succory

Psidium pyriferum

Chrisanthemum segetum

Chondrilla juncea

H

Mag-berries; or bird cherry

- Hairiff; clivers; or goosegrass

Halimus; or shrubby sea orach

Hare-bells

Hare's-ear

Hare's-ear, base shrubby; or sim- $\}$

pla nobla

Hare's-foot trefoil

Hare's lettrice or sow thistle

Hard-head; or knapweed

Hart's-tongue spleen-wort Asplinium scoln

Prunus padus

Galium aparine Atriplex halimus

Hyacinthus non-scriptus

Bupleurum tenuissimum

Phyllis nobla

Trifolium arvense

Sonchus oleraceus

Centaurea nigra

Asplinium scolopendrium $\uparrow$

Hart-wort, common

Tordylium officinale

* A very remarkable case is recorded in the Monthly Magazine for July, 1809, p. 573, of the cure of a cancer; by taling first a mercurial purge, and then twice a day, between meals, drinking about quarter of a pint of the juice of hairiff; part of the juice being mixed with hog's lard, and kept constantly applied to the wound, along with some of the leaves bruised.-In six months the cure was completed.

+ Asplinium scolopendrium hath many varieties,-Aiton's Hort. Kew。 
Hart-wort of Syria

Hart-wort, shrubby

Harmel; or wild Assyrian rue

Hassagay tree

Hawkweed

Hawkweed, base

Hawkweed, base; or yellow cichory Picris hieracioides Hawkweed, trailing, crookedseeded; or yellow eye Hawkweed, woolly; or downy
sowthistle

Tordylium syriacum Bupleurum fruticosum Peganum harmala Curtisia faginea

Hieraceum

Crepis

\section{Hyoseris}

Haw-thorn; quick; or white thorn C'ratcous oxyacanthd Haw-thorn, black American Hay, Burgundian ; or lucern Hay, camel's; or sweet rush Hazel nut

Hazel, witch, Virginian

Hazel, witch; or hop hornbeam

Heart's-ease; or pansy

Heart-pea

Heart seed

Heath; or ling, common

Viburmum prunifolium

Medicago sativa

Andropogon schoenanthus

Corylus avellana

Hamamelis virginiaca

Carpinus ostrya

Viola tricolor

Cardiospermum corindum

Brassica vesicaria

Erica vulgaris

Heath, base; or lesser marsh cistus Andromeda polifolia

$\left.\begin{array}{l}\text { Heath, black-berried; or crow, } \\ \text { or crake berries }\end{array}\right\}$ Empetrum nigrum

Heath, mountain

Heath, low pine

Heath peas; or bitter vetch

Heath, sea

Hedge-hog trefoil

Hellcbore
Saxifraga nivalis

Coris monspeliensis-

Orobus

Frankenia lovis

$\left\{\begin{array}{c}\text { Medicago polymorpha (in- } \\ \text { tertextu) }\end{array}\right.$

Helleborus

Hellebore, black; or christmas rose Helleborus niger

Hellebore, fennel-leaved black; or perennial Adonis

Hellebore, white

Hellebore, base

\} Adonis vernalis

Veratrum album

Limodorum

$\left.\begin{array}{c}\text { Hellebore, black ; helleboraster ; } \\ \text { bear's foot; or setterwort }\end{array}\right\}$ Helleborus foetidus

Helleborine; or base hellebore Serapias Helmet-flower; monk's hood; $\}$ Aconitum napellus
or wolf's-bane 
Hemlock, common spotted

Conium maculaîus

Helxine-see Beech wheat

Hemlock, great broad-leaved base Ligusticum peloponense

Hemlock, lesser; or fool's parsley. Aithusa cynapium

Hemlock, water

Hemlock, water dropwort

Hemp

Hemp, base

Hemp, base, or nettle hemp

Hemp agrimony

Hemp agrimony, base

Hemp agrimony, naked-headed $\}$

Hemp, sunn, or China

Hemp agrimony, water

Hemp, Virginian

Cicuta virosa

Oenanthe crocata

Camnabis sativa

Datisca cannabina

Galeopsis tetrahit

Eupatorium cannabinums

Ageratum conyzoides

$V$ erbesina

Crotalaria juncea

Bidens tripartita

Hen-bane ; or hog-bean conumon Hyoscyamus riger

Henbane, yellow; or tobacco Nicotiana tabacum

$\left.\begin{array}{l}\text { Henna; or alhenna; or Egyptian } \\ \text { privet }\end{array}\right\}$ Lawsonia inermis

Hen-weed, Guinea

Hepatica; or noble liverwort

Hep, or hip tree; or dog rose

Herb-bane

Petiveria alliacea

Anemone hepatica

Riosa canina

Orobanche

Herb-bane, great purple Lathroa clandestina

Herb-bennet; or avens, common Geum urbanum

Herb-Christopher; or bane-berries Actaa racemosa

Herb-Gerard; or goutwort

Herb of grace; or rue

Herb-impious; or cudweed

Egopodium podagraria

Ruta graveolens

Filago germanica

Herb-mastick; or mastick thyme Satureia thymbra

Herb-Paris; true-love; or one-berry Paris quadrifolia Herb-Paris of Canada; or three- $\}$ Trillium cernum
leaved nightshade

Herb-Robert

Geranium Robertianum

Herb-Trinity; or pansy

Herb-twopence; or moneywort Lysimachia nummularia

Herb, willow; or French willow Epilobium latifolium

Herb, willow; or purple loosestrife Lythrum salicaria

Herb, willow; or loosestrife

Lysimachia ephemerum

Hercules's club

$\left\{\begin{array}{c}\text { Zanthoxylum clava Her- } \\ \text { culis }\end{array}\right.$ 
Heron's bill

Erodium

Hiccory nut

Juglans alba

High-taper; white mullein; or
cow's lungwort

Hog-bean; or henbane

Hog-weed, American

Verbascum thapsus

Hollow-root; or tuberous moschatel Adoxa moschatellina

Holly common*; or holm

Hyoscyamus niger

Boerhauvia

Holly, hedge-hog (a variety)

Holly, Dahoon

Ilex aquifolium $\uparrow$

Ilex aquifolium ferox

Holly, knee; or butcher's broom; ? or Alexandrian laurel

Holly, sea; or eryngot. Hollyhock; hollyoak; or rose
mallow Alcea rosea

Ilex cassine

Ruscus aculeatus

Eryngium maritimum

- Honesty; moonwort; or satin flower Lunaria annua

Honewort; or corn parsley ', Sison segetum.

Honey flower

Honey locust; or three-thorned

Melianthus, major \& minor acacia

Gleditsia triacanthos

Honeysuckle; or woodbind, common

Lonicera periclymenum

Honeysuckle, upright, with red) berries; or dwarf Alpine Lonicera alpigena
cherry

Honeysuckle, fly

Honeysuckle, African Ay

Honeysuckle, American upright

Honeysuckle, French

Honeysuckle, trumpet

Lonicera xylosteum

Halleria lucida

Honeysuckle, grass; or white clover Trifolium repens

Honeysuckle, Jamaica

Honey-wort

Hop

Azalea viscosa

Hedysarum alhagi

Lonicera sempervirens

Bauhinia divaricata

Cerinthe

Humulus lupulus

* The bark of the common holly fermented, and afterwards washed from the woody fibres, makes the common birdlime. It is also said the bark of the birch tree makes good birdlime; but Pliny says the Italians made it from the berries of the misletoe: so that it appears to be a very antient method of carctung birds.

+ See aquifolium, in Index to Trivial Names.

$2 \mathrm{~N}$ 
Hop hornbeam ; or witch hazel

Horehound, common

Horehound, base

Horehound, base; or ironwort

Horehound, black

Horehound, common water

Hornbean*; or hard bean

Hornwort, common

Horse-foot

Horse-tail

Horse-tail, shrubby ; or sea grape

Hound's-tongue, common

Houseleek, cobweb

Houseleek, common

Houseleek, lesser ; or orpine

Houseleek, small annual

Houseleek, water, of Egypt

Hyacinth

Hyacinth, African blue umbellated Crinum africanum

Hyacinth, musk

Hyacinth, grape

Hyacinth, lily

Hyacinth, Peruvian

Hyacinth, starry

Hyacinth, Indian; or tuberose

Hyssop, common

Hyssop, hedge

Hyssop, hedge ; or grass-poley

Hyssop, mountain

Hypericum frutex
Carpinus ostrya

Marrubium vulgare

Stachys germanica

Sideritis

Ballota nigra

Lycopus europeus

Carpinus betulus

Ceratophyllum demersum

Buxbaumia

Equisetum

Ephedra

Cynoglossum officinale

Sempervivum arachnoideum

Sempervivum tectorum

Sedum telephium

Tilloca muscosa

Pistia stratiotes

Hyacinthus

Hyacinthus muscari

Hyacinthus botryoides

Scilla lilio hyacinthus

Scilla peruviana

Scilla amona

Polyanthes tuberosa

Hyssopus officinalis

Gratiola hyssopioides

Lythrum hyssopifolia

Thymbra

Spiraa hypericifolics

I

Jacinth-see Hyacinth

Jaca-tree

Jack in a box

Artocarpus integrifolite

Hernandia sonora

Jack by the hedge; or sauce alone Erysimum alliaria

Jacob's ladder; Greek valerian;
or charity

* Horntean receives its name from the hardness of the seed or nut ; it is in many places, wrongly, called hornbeam. 
Jalap, true

Jalap, white; or mechoacanna Japan earth-see Catechu Jasmine, common white Jasmine, yellow Indian Jasmine, Arabian ; or sambac Jasmine, base Jasmine, Cape Jasmine, African ilex-leaved Jasmine, fennel-leaved Jasmine, or lilac, Persian Jasmine, red Jasmine, scarlet; or trumpet flower Bignonia radicans Jasmine, common yellow Italian Jasminum fruticans Jasmine, yellow Carolina Ice plant; or diamond ficoides Jew's ear Immortal flower Immortal eagle flower; or female ? balsamine

Incense-wort ; or frankincense

Indian arrow-root

Indian leaf

Indian shot; or cane

Indian berry, cocculus

Indigo, common

Indigo, base ; or Jupiter's beard, ?

Inga of America

Job's tears

Johnsonia

Jonquil

Ipecacuanha; or Brasilian root Ipecacuanha, base
Convolvulus jalípa Mirabilis jalápa

Jasminum officinale Jasminum odoratissimum Nyctanthes sambac Cestrum nocturnum Gardenia florida Lantana africana Ipomoea rubra Syringa persica Plumeria rubra
Bignonia semper virens tallinum

Peziza auricula Gomphrona

Impatiens balsamina S.Maranta arundinacea $\{$ Thalia geniculata Melastoma malabathrica Canna indica Menispermum cocculus* Amorpha fruticosa

Mimosa inga

Coix lacryma

Callicarpa americana

Narcissus jonquillā Psychotria emetica Viola ipecacuarha

$\{$ Mesembryanthemum crysGnaphalium odoratissimum $\left\{\begin{array}{c}\text { Indigofera anil, and tinc- } \\ \text { toriat }\end{array}\right.$

* The berries of the menispermum cocculus are used to intoxicate fish.

$\uparrow$ Indigofera anil is said to be the wild indigo; the tinctoria is the true indigo. 
Ipecacuanha, base

Asclepias curassavica

Ipecacuanha, base Euphorbia ipecacuanha

Ipecacuanha, false; fever root;
or Dr. Tinker's weed

Iris, or orris, Florentine

Iris, Calcedonian

Iris florentina

Iris, bulbous, or Persian

Iris, Persian, or dwarf

Iris susiana

Iris xiphium

Iris persica

Iris, snake's-head; or hermodactyl Iris tuberosa

Iris, uvaria

Aletris woaria

Iris, wih a double bulb, called

Spanish nut

Iron-wood

Iron-wort; or base horehound

Iris sisyrinchium

Jucca-see Manihot

Judas tree (see Red-bud tree)

Jujube tree, blunt-leaved

Jujube tree, common, with shin-? ing leaves

July-fiower, clove

July-flower, queen's; rocket; or ? dame's violet

July-flower, stock

Junctianella-see Gentianella

Sideroxylum

Sideritis

Cercis silliquastrum Rhamnus jujuba

Rhamnus zizyphus

Dianthus caryophyllus

Hesperis matronalis.

Cheiranthus

Junquil-see Jonquil

Juniper, common

Jupiter's beard; or silver bush

Jupiter's beard, American; or base indigo

Jupiter's distaff

Ivy, common

Juniperus communis Anthyllis barva jovis Amorpha fruticosa Salvia

Ivy, ground; gill ; alehoof; turn-hoof; or cat's foot

Ivy tree; or dwarf laurel America

Hedera helix

Ivy ; or creeper of Virginia

Glechoma hederacea

of 7

Kalmia

K

Kale, or cabbage, sea

Hedera quinquefolia

Kali ; or glasswort

Crambe maritima

Kali, Egyptian

Salsola kali

f Mesembryanthemum nodi: \{. florum 
Kali, sal; alkali; jointed glass- ? wort; or kelp

Karatto (a variety)

Kex

Kedlock; or charlock

Kermes oak

Kidney-wort

Ketmia ; or Venice mallow

Salicornia herbacea Agava americana Cicuta

Sinapis arvensis Quercus coccifera Saxifraga geum King's spear; Aaron's rod; or
yellow asphodel

Kleinia; or foreign colt's-foot Cacalia kleinia Knapweed; knobweed; matfel-
lon; or hardbead Centaurea nigra

Knapweed, thorny

Knawel ; or German knot-grass

Knee holm; knee holly; or butcher's broom

Knot-berries

Knot-grass

Knot-grass, sea

Knot-grass, German; or knawel

Knot-grass, mountain

Knot-grass, verticillate
Centaurea spinosa Scleranthus annuus \} Ruscus aculeatus Rubus Polygonum aniculare Polygonum maritimum Scleranthus annuus Illecebrum paronychia Illecebrum verticillatum

\section{$\mathbf{L}$}

Laburnum ; ebeny of the Alps; or trefoil tree

Cytisus laburnum Ladder, Jacob's; Greek valerian;
or charity

Lad's-love; or southern-wood Artemisia abrotanum

Lady's bed-straw; or cheese rennet Galium verum

Lady's bower

Clematis Lady's comb; Venus's comb; or $\}$ Scandix pecten
shepherd's needle

Lady's cushion

Lady's finger; or kidney vetch Lady's mantle, common

Lady's mantle, silver-edged Lady's ruffle

Lady's seal; or black bryony

Lady's slipper

Saxifraga hypnoides Anthyllis vulneraria Alchemilla vulgaris Alchemilla alpina Lychnis sibirica

Tamus communis Lady's smock; or cuckow flower Cardamine vratensis 
Iady's traces, treble

Lamb's lettuce; or corn salad

Ophrys spiralis

Valeriana locusta

Lamb's-toes; or bird's-foot trefoil Lotus ornithopodioides

Lance-wood-see Cabbage tree

Larch tree

Lark-heel; or lark-spur

Lark-heel, bee

Lark-heel, perennial

Laser-wort ; or sermountain

Lavender; or false spikenard

Lavender, sea ; or limonium

Lavender cotton, common

Lavender, French; stickadore; or cassidone

Laver

Laurel, China

Pinus larix

Delphinium

Delphinium elatum

Delphinium grandifiorum

Laserpitum siler

Lavandula spica

Statice limonium

$\left\{\begin{array}{l}\text { Santolina } \cdot \text { chama-cyparis- } \\ \text { sus }\end{array}\right.$

Laurel, cherry*; or common laurel Prunus lauro-cerasus

Laurel of the antients; or com- $\}$ Laurus nobilis
mon bay

Laurel; or bay of Alexandria Ruscus racemosus $\uparrow$

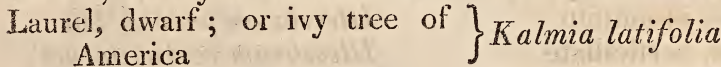

Laure!, Portugal

Laurel, flax-leaved

Laurel, sea-side

Laurel, spurge

Laurel, tongue; or tongue blade

Laurestinus

Prunus lusitanica

Daphne gnidium

Phyllanthus emblica

Daphne laureola

Ruscus hypoglossum

Viburnum tinus

* Cherry-laurel is said to be called so because it may be grafted on a cherry. The distilled water from the leaves of the cherry-laurel, is perhaps the most sudden poison we are acquainted with in this country; two spoonfulls of it will destroy a Jarge dog in about ten minutes.-In smaller doses it is said to produce intoxication; that there is reason to believe it acts in the same manner as opium and vinous spirit, but the dose is not so well ascertained. A pint of water distilled from $14 \mathrm{lbs}$. of black cherry stones bruised, hath the same deleterious effect. It is probable apricot kernels, peach leaves, walnut leaves, and whatever possesses the kernel fiavour, may have similar qualities.-Botanic Garden. See note to oenanthe crocata.

+ Ruscus racemosus is supposed to be the plant with which the antients crowned their victors and poets; the stalks being very pliable, may be easily twined into coronets for that purpose, and the leaves seem to represent those on antient busts.

Miller's Dict. 
Lead-wort, common

Leather-flower

Leather-wood

Leek

Lemon tree-see Limon

Lemon, water

Lentils

Lentisk ; or mastick

Lentisk; or mastick, Peruvian

Leopard's bane

Leopard's bane, German

Lettuce, common

Lettuce, hare's ; or sow thistle

Lettuce, lamb's; or corn salad

Lettuce, wild

Life, tree of ; or arbor vitæ

Life, tree of, Chinese Lignum aloes; calamba; or xylo-
aloes

Lignum vitæ; or pockwood

Lilac, common ; or pipe tree

Lilac, or jasmine, Persian

Lily, common white

Lily, African scarlet

Lily, asphodel

Lily, atamasco

Lily, belladonna

Lily, African blue

Lily, St. Beuno'st; or savoy spiderwort

Lily, conval; or lily of the valley Convallaria majalis

Lily, day

Lily, Guernsey

Plumbago europaa

Anthericum liliastrum

Hemerocallis fiava

Amaryllis sarniensis
Loranthus

Dirca palustris

Allium porrum

Passiflora laurifolia

Ervum lens

Pistacia lentiscus

Schinus molle.

Doronicum

Arnica montana

Lactuca sativa

Sonchus oleraceus

Valeriana locusta

Prenanthes muralis

Thuja* occidentalis

Thuija orientalis

Excocaria agallocha

Guaiacum officinale

Syringa vulgaris

Syringa persica

Lilium candidum

Amaryllis guttata

Hemerocallis flava, \& fuloa

Amaryllis atamasco

Amaryllis belladonna

Agapanthus umbellatus

* Thuja is sometimes with a $y$, as thuya.

+ Saint Beuno resided at Clynog, a little village ten miles south of Carnarvon is North Wales; he lived in the 7 th century, was an abbot, and having great riches, built a church there, and also a grand mausoleum for his own interment, called St. Beuno's chapel : he was brother to St. Winifred, the genius of the tamous well in Flintshire, who also lies interred in the church at Clynog.

Hutton's Tour in North Wrales, printed in 1803. 
Lily, Jacobæa

Lily, Japan and Ceylon

Lily, Mexican

Lily, orange, bulb-bearing

Lily, Persian

Lily, yellow martagon

Lily, purple martagon

Lily, scarlet martagon

Lily, crown imperial

Lily, crown royal

Lily, daffodil

Lily, hyacinth

Lily, superb

Lily, water; or Egyptian bean

Lily, white water

Lily, yellow water

Lily, Egyptian ; or Egyptian lotus Nymphaa lotus

Lily, lesser yellow water, with fringed flowers

Lily, thorn

Lily tree

Lime tree

Lime, brook

Lime, or linden tree

Limon tree

Limonium; or sea lavender

Ling; or heath, common

Lion's-foot, Candia

Lion's-leaf

Lion's-tail
Amaryllis formosissimet Amaryllis orientalis Amaryllis ragina Lilium bulbiferum Fritillaria persica Iilium superbum Litium martagon Lilium chalcedonicum Fritillaria imperialis Fritillaria regia Amaryllis (pancratiun) Scilla lilio-hyacinthus Gloriosa superba Nymphaa nelumbo Nymphaa alba Nymphaa lutea

Menyanthes nymphoides

Catesba a spinosa

Liriodendron liliifera

Citrus medica

Veronica beccabunga

Talia europaca

Citrus medica (a variety)

Statice limonium

Erica vulgaris

Catananche lutea

Leontice leontopetalum

Leonurus

Lipplehout; Hottentot cherry;
or Cape phyllyrea

Liquorice, true**

Cassine maurocenia

Liquorice, wild

Glycyrrhiza glabra Abrus precatorius

Liquorice, wild; or liquorice vetch Astragalus glycyphyllus Liquorice, wild; or sweet weed Capraria bifiora Liquorice, wild; or knobbed-? rooted liquorice vetch

Live-long; or common orpine 'Sedum telephium

* It is said the leares of liquorice make a good tea. 
Liver-wort

Lichen corallinus

Liver-wort, ash-coloured, ground Lichen caninus

Liver-wort, marsh

Riccia

Liver-wort, noble; or hepatica

Lizard-flower

Lizard's tail

Anemone hepatica

Satyrium

Saururus cernuus

Lizard, or scorpion's tail; or pepper Piper

$\left.\begin{array}{c}\text { Locker goulands; or globe ra- } \\ \text { nunculus }\end{array}\right\}$ Trollius europaus

Locust tree; or courbaril

Locust tree; or false acacia Locust tree, honey; or three-
thorned acacia Gleditsia triacanthos

Logwood; or bloodwood

London pride; or none so pretty Saxifraga umbrosa Loosestrife

Loosestrife Lysimachia

Hymenca courbaril

$\left\{\begin{array}{c}\text { Hamatoxylon campechia } \\ \text { num }\end{array}\right.$

$\left.\begin{array}{l}\text { Loosestrife, podded; or French } \\ \text { willow }\end{array}\right\}$ Epilobium

Loosestrife, purple; or willow herb Lythrum salicaria

Loosestrife, spiked

Loosestrife, willow herb, Spanish Lythrum hyssopifolia

Loosestrife, yellow Virginian

Lote; or nettle tree

Lotus of Egypt

Lotus, supposed of Homer

Lotus, honey; or white clover

Lovage, common

Love in a mist

Love lies a bleeding:

Lousewort; cockscomb; or rattle Pedicularis palustris

Lousewort; or stavesacre.

Gaura biennis

Celtis

Nymphcea lotus

Diospyros lotus*

Trifolium repens

Ligusticum levisticum

Passifiora fatida

Amaranthus melancholicus

Lousewort; cockscomb; or rat- $\}$ Rhinanthus cristagalli

Lucern; Burgundy hay; or medick Medicago sativa Lungwort, common spotted; or
Jerusalem cowslip

* Some think it was the diospyros lotus that gave the name and rise to the story of the Lotophagi in Homer; but others seem convinced it was the rhamnis lotus; for a description of which, see the memoirs of M. des Fontains, delivered to the Academy of Sciences at Paris, 1787 .

$\mathcal{Q} 0$ 
Lungwort, cow's; white mullein;
or high taper

$\left.\begin{array}{c}\text { Lungwort, golden ; or golden } \\ \text { mouse-ear }\end{array}\right\}$ Hieracium murorunt

Lupine

Lupinus

Lustwort

Drosera

Lychnidia; or base lychnis Phlox

Lychnis, scarlet*; or scarlet cross Lychnis chalcedonica Lychnis; campion; or bachelor's
button

Lychnis, wild; or rose campion Agrostemma coronarica

\section{M}

Mace-see Nutmeg

Mace, sweet-see Sweet Maudlin

Mace, reed ; or cat's-tail

Machingboy; or fish spurge

Maddert

Madder, E. India; or chay root

Madder, little field

Madder, petty

Madder, petty

Madder, crosswort ; or meadow

Madwort, with bladdery pods

Madwort of Galen

Madwort, German; wild bugloss; or great goosegrass

Mad-flower; or flag

Maho tree

Typha latifolia

Euphorbia hyherna

Rubia tivictorum

Mahogany

Oldenlandia umbellata

Sherardia arvensis

Rubia cordifolia

Crucianella

Galium boriale

Alyssum vesicaria

Marrubium alysson

Mahogany, Madeira; or vigniatico Laurus indica

Maiden-hair, common

Maiden-hair, Canada

Maiden-hair, English black

Maiden-hair, Tunbridge

Maiden-hair, golden

Asperago procumbens

Antholiza

Hibiscus

Sroietenia mahagoni

Maiden-hair, white; or wall rue Asplinium ruta muraria

Adianthum capillus veneris Adianthum pedatum

Asplinium adiantum nigrum

Trichomanes tunbrigense

Polytrichum commune

* See Cross, Jerusalem.

+ Mr. Spencer Smith hath lately introduced that valuable plant Smyrna madder, which it is hoped will soon become naturalized in our soil. 
Naiden-hair tree

Maize ; or Indian corn

Mallow; or maul, common

Mallow, African, or gooseberry-

- leaved

Mallow, base

Mallow, Carolina

Mallow, common Jew's

Mallow, Indian yellow

Mallow, Indian

Mallow, marsh

Mallow, musk

Mallow, rose; or hollyhock

Mallow, Syrian; or althea frutex

Mallow tree

Mallow, varied-leaved

Mallow, Portugal

Mallow, vervain; or hollyhock

Mallow, Venice; or ketmia

Mammee

Mammee, Sapota

Manchineel tree*; or poison tree

Mandraket

Mango tree

Mangostan

Mangrove treet; or mangles

Manihot; manihoc; jucca; or cassada

Manna seeds

Maple, common

$\left.\begin{array}{l}\text { Maple, greater; English syco- } \\ \text { more; or false plane }\end{array}\right\}$ Acer pseudo-platanus

Ginkgo biloba

Zea mays

Malva rotundifolia

Malva capensis

Malope malacoides

Malva caroliniana

Corchorus olitorius

Sida abutilon

Urena lobaia

Althoea officinatis

Malva moschata

Alcea rosea

Hibiscus syriacus

Lavatera arborea

Lavatera trimestris

Lavatera lusitanica

Malva alcea

Hibiscus trionum

Mammea americana

Achras sapota.

Hippomane mancinella

Atropa mandragora Mangifera indica Garcinia mangostana Rhizophora mangle

Jatropha manihot

Festuca fluitans

Acer campestris

* The Spaniards call this tree manzanillo, deriving it from the Spanish wora manzana (an apple) which the fruit of this tree very much resembles.

T The fruit of the mandrake was by the antients called love apples, and we may infer the antiquity of the popular notion of its virues from Gen. c. xxx, v. 14, \&c. As to the root resembling the human form, is an artful fable to deceive the ignorant and credulous, who have sometimes been imposed upon with fictitious images shaped from the fresh rocts of bryony, angelica, and other plants, pretending to be from the mandrake.

* The bark of the mangrowe tree is said to answer the same purposes in tanning as the oak bark. 
Maple, sugar

Maracock ; or passion flower

Mare's tail, common

Marigold, common garden

Marigold, African

Marigoid, corn

Marigold, field

Marigold, fig; or ficoides

Marigold, fig, false; or groundsel tree with a ficoides leaf $\}$

Marigold, French

Marigold, marsh

Marjoram, knotted, or knobbed

Marjoram, base

Marjoram, Spanish

Marjoram, wild, or common

Marjoram, pot; winter sweet ; or origany

Martagon lily

Marvel of Peru, common

Marum, common

Marum plant, Norfolk

Marum, pennyroyal-scented

Marum, Syrian, or Cretan

Masterwort

Masterwort, black, or greater

Mastich, herb; or mastich thyme Thymus mastichina

Mastich, or lentisk, Peruvian Schinus molle

Mastich, or lentisk tree

Matfellon; knapweed; or hard-
head

Mat-weed

Mat-weed, hooded

Maudlin, sweet

Mawseed

May, or May bush; or white thorn May-weed; or mays*
Acer saccharinum

Passiflora

Hippuris vulgaris

Calendula officinalis

Tagetes erectu

Chrysanthemum segetum

Calendula arverisis

Mesembryanthemum
Cacalia ficoides

Tagetes patula

Caltha palustris

Origanum majorana

Origarum

Urtica dodartii

Origanum vulgare

Origanum heracleoticum

Lilium martagon

Mirabilis jalapa

Teucrium marum

Arundo arenaria

Milissa fruticosa

Origanum creticum

Inperatoria ostruthiums

Astrantia

Pistacia lentiscus

Centaurea nigra

Stipa tenacissima

Lygeum spartum

Achillea ageratiom

Pupaver somniferum

Cratogus oxyacantha

Anthemis cotula

* Anthemis arvensis, and anthemis cotula, are both/field plants; the first is the field chamamile, biennial and scentless, and the seeds crown-margined;-the other is the may-weed, or mays, and is annual, strong-scented, and the seeds naked; and if the hands are rubbed over with this plant, it is said to prevent bees from stinging. 
Meadia; or American cowslip Dodecatheon meadea

Meadow-sweet;
meadows

Mealy tree, pliant; or wayfaring
tree Viburnum lantana

Mechoacanna; or white jalap Mirabilis jalapa

Medick

Medicugo

Medick; lucern; or Burgundy hay Medicago sativa

Medick, sea

Medlar

Medicayo marina

Medlar of Louisiana

Medusa's head

Melancholy; or sorrowful tree

Melilot

Melon

Melon, water ; or citrul

Melon thistle

Mespilus

Diospyros virginiana

Euphorbia caput meduse

Nyctanthes arbor tristis

Mercury, dog's; or dog's cabbage Theligonum cynocrambe

Mercury

$\{$ Trifolium melilotus offici-

$\left\{\begin{array}{r}\text { nolis } \\ \text { Cucto }\end{array}\right.$

Cucumis melo

Cucurbita citrullus

Cactus melocactus

Mercury, English garden; all- \} Chenopodium bonus Hengood ; or good Henry

Meum; or spignel

Mezereon

Mignonette

Milfoil; or yarrow

Milfoil, or violet, water

Milfoil, water

Milfoil, water, or hooded; or $\}$ bladderwort

Milk, or white wood

Milk-wort

Milk-wort; or spurge ricus

Aithusa meum

Daphne mezereum

Reseda odoratu Achillea millefolium Hottonia palustris Myriophyllum

Milk-wort, sea; or black salt-wort Glaux maritima

Millet; or panic grass

Millet, common

Millet, Indian ; or doura

Milt-waste

Mint, horse

Mint, spear

Utricularia vulgaris

Bignonia leucoxylon

Polygala

Euphorbia

Mint, pepper

Panicum miliaceum

Milium effusum

Mint, cat; or nep

- Holcus sorghum Asplinium

Mentha iluestris

Mentha viridis

Mentha piperita

Nepeta cataria 
Mint, balm-cat; or wild calamint Melissa nepete

Methridate; or treacle mustard Thlaspi campestre

Misletoe,* common

Moly, with lily flowers; or yellow ? garlic

Mombin; or Brasilian plum Spondias mombin

Money-wort; or herb two-pence Lysimachia nummularia.

Money-wort, base

Monkey-bread; or sour gourd

Monk's-head

Monk's-hood; or helmet flower

Monk's-hood, variegated

Moon-seed

Moon trefoil ; or tree medick

Moon-wort; satin flower; or ?

honesty
Moor, or moss berries; or cran- \{

Morel berries

Moringa

Viscum album

Allium moly
Spondias mombin
Lysimachia nummu
Sibthorpia europara

Adansonia digitata

Leontodon

Aconitum napellus

Aconitum cammarum

Menispermum

Medicago arborea

Lunaria annua

Mroringa

Moschatel,tuberous; orhollow-root Adoxa moschatellina

Mosses

Musci

Moss, pill ; or pepper grass

Moss tree

Moss, upright fir

Moss, water

Mother-wort

Mould

Mouse-ear

Mouse-ear, creeping

Mouse-ear, golden; or golden lungwort

Mouse-ear chickweed

Mouse-ear scorpion grass

Mouse-tail

Pilularia globulifera

Lichen usnea

Lycopodium selago

Fontinalis

Leonurus cardiaca

Mucor

Hieracium dubium

Hieracium pilosella

Much-good; ow mountain parsley Athamanta oreoselinum Mud-wort; or least water plantain Limosella aquatica

* Misletoe is a parasitical plant, and grows on the branches of trees, adhering thereto by the viscosity of its berries, which also serve for birdlime. Birdlime is also made from the inner bark of the holly. - See note to holly. 
Mug-weed; or cross-wort

Mugwort, common

Mulberry tree

Mulberry; or strawberry blite

Mule, Fairchild's
Valantia cruciata Artemisia vulgaris Morus

Blitum capitatum

$\{$ Dianthus superbus et dianthus caryophillus

Mule-wort; or moon or mule's fern Hemionitis

\section{Mullein}

Mullein, black

Mullein, moth; or blattaria

Mullein, white; high taper; cow's lungwort

Mushroom

Mushroom, esculent; or champignon

Mushroom, cup

Mushroom, fairy

Musk, geranium

Musk, mallow

Musk-seed

Mustard

Mustard, field ; or charlock

Mustard, base

Mustard, buckler; or base mithridate

Mustard, hedge

$V$ erbascum

$V$ erbascum nigrum

Verbascum blattaria

or $\}$

Verbascum thapsus

Agaricus

\} Agaricus campestris*

Peziza

Agaricus

Erodium moschatum

Malva moschata

Hibiscus abelmoschus

Sinapis

Sinapis arvensis

Cleome

Biscutella

Erysimum officinale

Mustard, mithridate of Dioscorides Lepidium perfoliatum

Mustard, mithridate; or treacle Thlapsi campestre

Mustard, base mithridate; or sci- $\}$ atica cress

Mustard, tower; or wall cress

Mustard, base tower

Myrrhis; or wild myrrh; or

Myrtle sweet Cicely

\author{
Iberis
}

Turritis

Arabis

\}Chorophyllum sylvesire

Myrtus

* Agaricus deliciosus is said to deserve its name, as being the most delicious mushroom known, though its appearance is not very inviting; the colour being' a dirty brown, and the juice of a deep orange, soon turning to a livid green, whereever the fungus is touched or bruised. This fungus is much admired throughout Province, but though a native of England and Scotland, is not known at our tables. Smith's Tour on the Continent, printed in 1793. 
Myrtle, candleberry

Myrtle, Dutch; or gale

Myrica cerifera

Myrica gale

N

Naked ladies; or meadow saffron Colchicum autumnale

Narcissus polyanthus

Narcissus

Narcissus; or daffodil, sea

Narcissus tazetta

Narcissus

Nard-see Spikenard

Nard ; or mat - grass

Pancratium maritimum

Nard, Celtic

Naseberry tree

Nasturtion; or cress, Indian

Navel-wort

Navel-wort, base, or African Navel-wort, spring, or perennial
Venus's

Navel-wort, taller Venus's

Navel-wort, lesser Venus's*

$\left.\begin{array}{c}\text { Navel-wort, water; or marsh } \\ \text { pennyroyal }\end{array}\right\}$ Hydrocotyle vulgaris

Nardus stricia

Valeriana celtica

Sloanea

Trapoolum majus

Cotyledon

Crassula coccinea

Cynoglossum omphalodes

Cynoglossum lusitanicum Cynoglossum linifolizm

Navew; rape; or cole

Nectarine (a variety)

Nep; or catmint

Nettle

Brassica napus

Nettle, balsam

Nettle, dead; or Archangel

Nettle, hedge, dead hemp

Nettle, dead yellow

Nettle, Roman

Nettle, shrubby hedge

Nettle tree; or lote

Net-work

Nickar tree

$\{$ Amygdalus persica (fruc

$\{$ tibus glabris $\}$

Nepeta cataria

Urtica

Melittis melissophyllum

Lamium album

Galeopsis tetrahit

Galeopsis galeobdolon

Urtica pilulifera

Prasium

Celtis

Eriocaulon decangulare

Guilandina bonduc

Nightshade

Solanum

Nightshade, American; or porkweed

Phytolacca decandria

* Venus's navel-worts receive the name from a hollow in the seeds being a supa posed resemblance of the navel. 
Nightshade, base

Nightshade, deadly; or dwale Atropa belladonna

Nightshade, common enchanter's Circaa lutetiana

Nightshade, Malabar

Basella

Nightshade, three-leaved; or Ca- $\}$ Trillium cernuum
nada herb-paris

Nightshade, woody; or bitter-sweetSolanum dulcamara

Nil; or American blue bindweed Convolvulus nil

Nip; or stinking ragwort

Nipple-wort; or wart-wort Lapsana communis

Senecio jacobaa

Nipple-wort, or cichory, warted Lapsana zacintha

Noli me tangere; or yellow bal-
samine Impatiens noli tangere

Noneso pretty; or London pride Saxifraga punctata

Nopal; or cochinil fig

Nose-bleed; or yarrow

Nostac-see Star-jelly

Nut, Areca

Nut tree, hazel

Nut, bladder, English

Nut, bladder; or whortle berry, African

Nut, bladder, laurel-leaved

Nut, cashew; or acajou

Nut, chocolate

Cactus cochenillifer Achillea

Nut, Byzantine; or Spanish nut Corylus colurna

Nut, clearing

Nut, coco, or palm

Nut, earth, or pig

Nut, fausel, or palm

Nut, ground, of America

Nut, hiccory

Nut, Malabar

Areca catechu

$\{$ Corylus avellana* (silves-

tris, vel grandis)

Staphylea pinnata

Nut, pea-earth

Nut, physic, or purging

Nut, physic, or purging

Royera

Ilex

Anacardium occidentale

Theobroma cacao

Strychnos potatorum

Cocos nucifera

Bunium bulbocastanum

Areca

Arachis hypogaa

Juglans alba

- Justicia adhadota

Lathyrus pisifolia

Jatropa curcas

Croton

* Corylus avellana hath its specific name from the town Avellina, in Naples; for in the district of that town are planted more nut trees than in any country whatever: it is said that the trade in nuts produces annually about $£ 11,250$ to the town of Avellina.

$2 \mathrm{P}$ 
Nut, pistacia

Nutmeg

Nut, Spanish

Nux-vomica
Pistacia vera

Myristica moschata

Iris sisyrinchium

Strychnos nux-vomica
Oak, common

Oak, dwarf (a variety)

Oak, evergreen, common

Oak of Cappadocia :

Oak of Jerusalem

Oak, poison; or varnish tree

Oak, Indian; or teak-wood

Oak, kermes; or grain oak

Oak, live

Oak, cork

Oats, common, white, black, or ? , brown (alba, nigra, fusca)

Oats, animated

Oats, common wild

Oats, sea-side, of Carolina

Oats, wild bearded

Occulus Christi

Ocra; or Indian sorrel

Oil tree; agnus castus; or palma Christi

Oily grain*, called bonny in Carolina

Old man's beard; or traveller's joy

Old man's head (a variety)

Oleander; or rose bay

Olibanum

Oleaster; or wild olive

Oleum rhodii $\uparrow$
Quercus robur

Quercus robur humilis

Quercus ilex (integrifolia)

Ambrosia maritima

Chenopodium botrys

Rhus vernix

Tectona grandis

Quercus coccifera

Quercus molucca

Quercus suber
\}

Avena hispida

Avena fatua

Uniola

Bromus

Inula occulus Christi

Hibiscus esculentus

Ricinus communis

Sesamum orientale

Clematis vitalba

Dianthus deltoides

Nerium oleander

Juniperus lycina

Elaagnus

Aspalathus

* Called oily grain, from the seeds of this plant yielding by expression a greater quantity of oil than almost any other known plant.-The Italian sesame is the astragalus sesameus.

+ That fine perfume, called oleum rhodii, is supposed to be the essential oil of 3 species of aspalathus.

Some think the oleum rhodii is an extract from the root of a species of con: volvulus, either scoparius or floridus. 
Olive, common*

Olive, sweet-scented

Olea europaca

Olive, spurge

Olive, wild, of Barbadoes

Olea fragrans

Daphne oleoides

Bontia daphnoides

One-berry; true love; or herb Paris Paris quadrifolia

Onion

Onion, many-bulbed $\uparrow$

Allium cepa

Onion, umbel-bearing

Onion, sea ; or squill

Onion, Welch

Opulus; or marsh elder

Allium multibulbosum

Allium magicum

Scilla maritima

Allium jistulosum

Viburnum opulus

Orange tree, Seville

Citrus aurantium

Orange, + China (a variety)

Orange, mock

Orchilla; or archil

Citrus aurantium (sinensis)

Origany, pot; or winter sweet?

marjoram
Origany of Crete; or Cretan marum

Ornotta, see Anotta

Orpine; or live long

Orpine, base

Orpine, lesser

Orpine, true, of Imperatus

Orach, garden

Philadelphus coronarius

Lichen roccella

Origanum heracleoticum

Origanum creticum

Bixco orellana.

Sedum telephium

Andrachne-telephioides

Crassula

Telephium imperati

$\left.\begin{array}{l}\text { Orach, berry-bearing; or straw- } \\ \text { berry blite }\end{array}\right\}$ Blitum capitatum

* Olive oil is asserted to possess many excellent qualities : if the body is frequently smeared over with it, and the garment next the skin soaked in it, it.will prevent the infection of the plague; it will prevent the bite of the scorpion, and other venomous reptiles; and it will keep of musquitoes.-In Tunis, if a person is bit by a scorpion, or other venomous reptile, the part is immediately scarified, and olive oil rubbed in as soon as possible, which arrests the progress of the venom.

Jackson's Commerce of the Mediterranean, printed in 1805.

Quere. If it would affect the bite of a mad dog.

+ The many-bulbed onions are to be set whole at Spring, at about a foot distant; which do not run up to seed, but at the time of taking up, each onion will form a cluster of bulbs under ground from 2 or 3 to 6 or $7 ;-$ and will sometimes bear small onions at the top of the stalk, if they have not clustered below.

$\mp$ A small orange, called at the Cape of Good Hope naretje, and is distinguished, like the citron, by a protuberance at the upper end, is said to be superior in taste to every sort of oranges. 

Orach, creeping shrubby
Airaphaxis inermis
Orach, wild; goosefoot; or fat hen Chenopodium viride
Orach, shrubby sea; or halimus Atriplex halimus
Orris, or iris, Florence
Iris florentina
Osier
Salix viminalis
Osier, yellow
Salix vitcllina
Osier, brown ; or almond-leaved
Osmund, royal; or flowering fern
Oswego tea
Ox-eye, foreign
Ox-eye of old authors
Ox-eye ; or greater daisy
Oxslips (a variety)?
Ox-tongue
Oyster-green
Salix anyggdalina
Osmunda regalis
Monarda didyma
Buphthalmum
Anthemis
$\left\{\begin{array}{c}\text { Chrysanthemum leucanthe- } \\ \text { mum. }\end{array}\right.$
Primula veris (elatior)
Picris echioides
Ulva lactuca

t

Paddock; or toad-stool

Paddock-pipe; or toad-pipe

Pæony

Pagils; paigles; or cowslips

Painted ladies (a variety)

Palm, greater; or date, or dactyl tree

Palm, lesser or dwarf; or palmetto Chamarops humilis

Palmetto royal; or cabbage tree

Palm, coco nut

Palm, fausel nut

Agaracus

Equisetum

Poxonia

Primula veris (officinalis)

Dianthus deltoides

Phonix dactylifera

Palm, Malabar: called ampana and corimpana and corimpana
Palm, wild Malabar; called ka-
tou-jndel

Corypha umbraculifera

Cocos nucifera

Areca

Borassus fabelliformis

Elate silvestris

Palm, mountain, with largest leaves; called codda panna $\}$

Palm, sugar Arenga saccharifera

Palm, with ringed stems; called

todda panna
Palm, with bipinnate leaves;

called schunda panna
Palma Christi; Agnus castus; or oil tree

Cycas circinalis

Caryota urens

Ricinus communis 
Pampelnoe; or shaddock(a variety)Citrus aurantium

\section{Pansy}

Papyrus, Chinese

Papyrus, antient Egyptian

Papaw tree

Papaw tree of $\mathrm{N}$. Ámerica

Paradise, grains of

Park-leaves; or tutsan

Parsley; or petroseline

Parsley, base

Parsley, corn; or honewort

Parsley, cow's-see Chervil
Viola tricolor.

Moris papyrifera

Cyperus papyrus

Carica papaya

Annona triloba

Amomum granum paradisi

Hypericum androsamum

Apium petroselinum

Cancalis

Sison segetum

Parsley, dog's, or fool's; lesser hemlock; or Cicely

Parsley, knotted

Parsley, Macedonian

Parsley, water ; or smallage

Parsley, milk

Fthusa cynapium

Parsley, mountain; or much-good Athamanta oreoselinum

Parsley, purple-flowered hedge Tordylium anthriscus

Parsley, stone

Tordylium nodosum

Bubon macedonicum

Apium graveolens

Selinum sylvestre

Parsley piert; break stone; or $\}$ Aphanes arvensis
percepier

Parsnep

Parsnep, cow's

Parsnep, prickly

Parsnep, water, the greater

Parsnep, water, the lesser

Pasque-flower

Passion-flower; or maracock

Pastel; or woad, common

Patience rhubarb

Pea*

Pea, chich; or garavances
Pastinaca sativa

Heracleum sphondylium

Echinophora

Sium latifolium

Sium nodiflorum

Anemone pulsatilla

Passiflora

Isatis tinctoriá

Rumex patientia

Pisum sativum

Cicer arietinum

* Plants are not only nourished by the roots, but also by their leaves; those that have succulent leaves of open texture, such as peas, beans, turneps, potatoes, \&c. imbibe much of their nourishment from the air; and therefore less impoverish the soil than wheat, larley, oats, rye, \&c. whose leaves being of firmer téxture, depend more upon the root for support.-And as it is confirmed by observation that oil is the principal food of plants, all those vegetables, whose sceds abound with oil, are great impoverishers of the soil, as rape, hemp, flax, \&c. 
Pea, or vetch, chichling

Pea, earth nut

Pea, everlasting

Pea, heart

Pea, heath, or wood; or bitter vetch Orobus sylvaticus

Pea, painted lady

Pea, pigeon

Pea, sea-side pigeon

Pea, sweet-scented

Pea, Tangier

Pea, winged

Peach

Peach, wolf's

Pear tree, common

Pear, avocado, or alligator

Pear, bachelor's

Pear, garlic

Pearl-wort

Pellitory, or parietary of the wall

Pellitory of Spain

Pellitory of Spain, false

Pellitory; or tooth-ach tree

Pennyroyal Pennyroyal, stag, or narrow-
leaved upright

Pennyroyal, Virginiais

$\left.\begin{array}{c}\text { Penny-wort, marsh; or water } \\ \text { navel-wort }\end{array}\right\} H y$ drocotyle vulgaris

Penny-wort, or navel-wort, wall

Penguin ; or wild ananas

Penstemon

Pepper

Pepper, black

Pepper, Guinea

Pepper, bell

Pepper, bird
Lathyrus

Lathyrus pisifolia

Lathyrus latifolia

Cardiospermum corinduma

Lathyrus

Cytisus cajan

Sophora occidentalis

Lathyrus odoratus

Lathyrus tangitanus

Pisum ochrus

$\{$ Amygdalus persica*

\{ Fructibus lanuginosis

Solanum lycopersicum

Pyrus communis

Laurus persea

Solanum mammosum

Cratceva tapia

Sagina procumbens

Parietaria officinalis

Anthemis pyrethrum

Chrysanthemum frutescens

Zanthoxylum

Mentha pulegium

Mentha cervina

Satureja

Cotyledon serrata

Bromelia pinguin

Chelone penstemor

Piper

Piper nigrum

Capsicum annuum

Capsicum grossum

Capsicum baccatum

* Amygdalus persica, called so from being supposed a native of Persia.

N.B. The peach and neclarine are considered as only varieties of the sams species. 
Pepper, bonnet

Pepper, Cayenne*

Pepper, Barbary

Pepper, hen

Pepper, Jamaica ; or all-spice

Pepper, Peruvian

Pepper, long

Pepper, wall; or stone-crop

Pepper, water; or arse-smart

Pepper-grass

Pepper, pot

Pepper tree

Pepper-wort ; poor-man's per ; or dittander

Percepier ; or parsley piert

Periwinkle, greater

Periwinkle, lesser

Periwinkle, Madagascar

Persicaria; or spotted arse-smart Polygonum persicaria

Persicaria, Eastern

Pestilent-wort

Petroseline; or parsley

Pheasant's eye, common

Pheasant's eye pink (a variety)

Phillyrea ; or mock privet

Phillyrea, false

Phillyrea of the Cape; or Hottentot cherry

$\mathrm{Phu}$, setwall; or garden valerian Valeriana phu

Pile-wort ; or lesser selandine

Pimento; all-spice; or Jamaica $\}$ pepper

Pimpinel, common

Pimpinel, round-leaved water

Pimpinel of the woods, yellow

Pin-pillow ; or pin-cushion

Pineaster (a variety)
Capsicum

Capsicum frutescens

Capsicum

Capsicum

Myrtus pimenta

Schinus molle

Piper longum

Sedum aire.

Polygonum hydropiper

Piluraria globulifera

Capsicum

Vitis arborea
\} Lepidium latifolium

Aphanes arvensis

Vinca miajor

Vinca minor

Vinca rosea

Polygonum orientale

Tussilago petasites

Apium petroselinum

Adonis autumnalis

Dianthus deltoides

Phillyrea media

Rhamnus alaternus

Cassine maurocenia

Ranunculus ficaria

Myrtus pimenta

Anagallis arvensis

Samolus valerandi

Lysimachia nemorum

Cactus curassavicus

Pinus silvestris

* Quere, Should it not rather be called Kiang pepper (a province in China), as it is said they have a shrub that bears a remarkably hot pepper, only fit for sauces? - see note to capsicum. The chief exports from Cayenne are said to be sugat and coffee. 
Pine, frankincense

Pine, Cembra

Pine, Scotch

Pine, stone

Pine, Weyinouth, or New England

Pine, ground, or dwarf

Pine, stinking ground

Pine, heath low

Pine apple, or ananas

Pine apple, wild

Pine apple, wild; or penguin

Pink

Pink, wild sand

Pink, China

Pink, maiden

Pink, Indian ; or quamoclit

Pink, matted

Pink, mountain

Pink, Indian

Pink, Deptford

Pink, sea; or thrift

Pink, sea, the greater

Pipe-tree* ; or common lilac

Pipe-tree, pudding

Piperidge bush; or berberry

Piquets; or piquettees (a carnation) Dianthus caryophyllus

Pistacia nut

Pishamin, or persimon plum

Pistacia, black Virginian hazelleaved

Pitch-tree

Pitajaya of California

Plane tree

Plane tree, false; greater maple; or sycomore

Plant, burning thorny

Plant, egg

Plant, humble sensitive
Pinus todot

Pinus cembres

Pinus silvestris

Pinus pinea

Pinus strobus

Teucrium chamopithys

Camphorosma

Coris monspeliensis

Bromelia unamas

Renealmia exaltata

Bromelia penguin

Dianthus

Dianthus arenarius

Jianthus chinensis

Dianthus deltoides

Iponoea quamoclit

Dianthus virgineus

Dianthus glaucus

Spigelia marilandia

Dianthus armeria

Statice armeria

Statice psend-armeria

Syringa vulgaris

Cassia fistula

Berberis vulgaris

\section{Pistacia vera}

Diospyros virginiana

Hamamelis virginica

Pinus picea

Cactus, pitajaya

Platanus.

Acer pseudo-platanus

Euphorbia

Solanum melongeno

Mimosa pudica

* Pipe-tree, called so from the branches of -this tree, when the pith is taken out, serving for pipes in syringes. 
Plant, sensitive

Plant, base sensitive

Plant, self-moving

Plantain, common broad
Mimosa

Aschinomene

Hedysarum gyrans

Plantago major

Plantain; hartshorn; or buckshorn Plantago coronopus

Plantain, rose

Plantago major (a variety

Plantain, ribbed ; or ribwort

Plantain, star-headed water

Plantago lanceolata

Alisma plantago

Plantain, least water; or mudwort Limosella aquatica

Plantain tree; or bread tree

Musa paradisiaca

Pliant mealy tree; or wayfaring tree Viburnum lantana

Plum tree

Prunus domestica

Plum, Calaba Plum, black American ; cocoa ; $\}$ Chrysobalanus icaco
or maiden

Plum, Assyrian ; or Sebesten

Plum, bay; or guava

Cordia sebestena

Psidium pyriferum

Plum, hog, Brasilian, or Jamaica Spondias myrobalanus

Plum, Indian date

Plum, pishamin, persimon, or pitchumon

Poccoon, or puccoon

Pockwood; or lignum vitæ

Poison tree; or manchineel

Poison tree

Diospyros lotus

Poison ash, or oak; or varnish tree Rhus vernix

Poison berry

Poison bush; or spurge

Poley, mountain

Poley grass; or hedge hyssop

Polyanthus (a variety)

Polyanthus narcissus

Polypody

Pomegranate

Pompion

Pond weed

Diospyros virginiana

Sanguinaria canadensis

Guaiacum officinale

Hippomone manchinella

Rhus toxicodendron

Pond weed; horn-leaf; or hornwortCeratophyllum demersum

Pond weed, treble-headed

Pontic; or Roman wormwood

Poplar

Poplar, common ; or aspen

Cestrum

Euphorbia

Teucrium polium

Lythrum hyssopifolia

Primula veris (elatior)

Narcissus tazetta

Polypodium

Punica granatum

Cucurbita pepo

Potomogeton natans

Zannichella palustris

Artemisia pontica

Populus

Populus tremula

Poplar, Lombardy; or Po poplar Populus dilatata 20 
Poplar, balsam ; or tacamahaca Populus balsamifera Popple; or cockle Poppy Poppy, conmon corn Poppy, red horned* Poppy, yellow horned

Poppy, prickly; or fig infernal Argemone

Poppy, spatling; or white behen Cucubalus behen Pork weed; pork physic; or $\}$ American nightshade

Potatoe, common Phytolacca decandria

Potatoe, Indian ; or yam Potatoe, or batata; Spanish Prick, or skewer wood; or spindle tree

Primrose, common

Primrose, common night

Primrose tree

Primrose, peerless

Prince's feather

Privet; or primp

Privet, Egyptian; or hennat

Privet, evergreen

Privet, mock; or phyllyrea

Privy-saugh

Prune; or plum

Puccoon

Puccoon, base Virginian

Pudding pipe tree

Puff-ball ; or fuz-ball

Pulegium; or pennyroyal

Pulsatilla; or pasque flower

Pumpkin (see Pompion)

Purging grane, oily

Purslain, common

Solanum tuberosum

Dioscorea bulbifera

Convolvulus batatas

Euonymus

Primula veris (acaulis)

Oenothera biennis

Oenothera fruticosa

Narcissus odorus Amaranthus caudatus

Ligustrum vulgare.

Lawsonia inermis

Rhamnus alaternus

Phillyrea

Ligustrum

Prunus domestica

Sanguinaria canadensis

Anchusa virginica

Cassia fistula

Iycoperdon bovista

Mentha pulegium

Anemone pulsatilla

Cucurbita pepo

Sesamum orientale

Portulaca oleracea

* A curious circumstance attends the horned poppy; when the flower fades, the pistillum or seed-vessel elongates to 10 or 12 inches, to contain more seed? whence the name.

tA powder is prepared from the leaves of Egyptian privet called alcanna, alken$n a$, or henna, in which the city of Cairo employs a considerable trade. It is much used by the Turks, as well as in Egypt, for colouring the nails and bair of a gold colour; in dying it gives a yellow colour with water, and red with vinegar. 
Purslain, horse

Purslain, sea

Purslain, water

Purslain tree

Purslain tree, sea

Pyracantha
Sesuvium portulacastrum Atriplex portulacoides Peplis portula Crassula cotyledon Atriplex halimus Mespilus pyracantha

2

Quake grass; or cow quakes Briza

Quamoclit; or Indian pink Ipomoea quamoclit

Queen of the meadows; or mea-
dow sweet

Quick; or white thorn Crategus oxyacantha

Quicken; wicken; quick-beam; or mountain ash

Quince tree

Quill-wort

Quinquina; or Jesuit's bark

Sorbus aucuparia

Pyrus cydonia

Isoetes lacustris

Cinchona officinalis

\section{R}

Radish, common esculent

Radish, horse

Radish, or cress, water

Ragged Robin; or lychnis cuc-?

kow flower

Raphanus sativus

Cochlearea armoracia

Sisymbrium nasturtium

Lychnis flos-cuculi

Ragwort, common; staggerwort;

or nip

Ragwort, African

Ragwort, sea

Ragworts of old authors

Ragworts of old authors

Rampions,* common esculent

Rapions, horned

Rampions, crested

Rampions with scabious heads; or hairy sheep scabious

Ramsons; or bear's garlic
Senecio jacobaa

Othonna

Cineraria maritima

Senecio

Solidago

Campanula rapunculus

Phyteuma orbicularis

Lobelia phyteuma

Jasione montana

Allium ursinum

* Rampions, so called from the old Latin name rapunculus; the esculent part is the root, which, when young, is sliced and eat in salads, and is said to be very wholesome and nourishing. 
Ranunculus; or crow-foot, com- $\}$ Ranunculus asiaticus
mon garden

Ranunculus, globe; or locker
goulands Trollius europous

Rape, cole, or navew

Rape, broom

Brassica napus

Raspberry

Raspberry, flowering

Orobanche

Rubus idaeus

Rattle; cockscomb; or lousewort Pedicularis palustris

Rattle, yellow; cockscomb; or
elephant's head Rhinanthus crista-galli

Rattlesnake root, Senega

Rattlesnake root, Dr. Witt's

Polygala senega

Prenanthes altisima

Rattlesnake weed

Eryugium aquaticum

Red-bud tree; or Canada Judas treeCercis canadensis

Red-worts, Spanish; or straw- $\}$ Arbutus unedo
berry tree

Reed, common

Reed, burr

Reed, Indian flowering

Reed mace

Reed, sand*

Arundo phragmitis

Sparganium

Canna angustifolia

Rennet, cheese; or yellow ladies bedstraw

Rest-harrow; petty whin; or cammock

Typha latifolia

Arundo arenaria

Galium verum

\}ononis

Rhamnus, base; or sea buckthorn Hippophae rhamnoides

Rein deer liverwort

Rhapontic

Rhubarb

Rhubarb, true Turkey

Rhubarb, British

Lichen rangiferinus

Rheum rhaponticum

Rheum

Rheum palmatum

Rhubarb, monk's; or patience ? rhubarb

Rumex britanica

Ribwort; or ribbed plantain

Rice

Rice, wild

Ricinus, base

Rumex patientia

Plantago lanceolata

Oryza sativa

Zizania aquatica.

Croton

Roan tree; mountain ash; or wicken Sorbus aucuparia

* See note to Sea rush. 
Robinson Crusoe's coat

Robert herb

Rocambole; or Turkey garlic

Rock germander

Rock rose

Rocket

Rocket, base or weld

Rocket, corn

Rocket, marsh

Rocket, sea

Rocket, square-podded of Mont-
pelier

Rocket, water or wood

Rocket, Winter

Rocket, wall

Rocket; dame's violet; or queen's July-flower

Rod, Aaron's; king's spear; or yellow asphodel

Rod, bloody

Rod, golden

Rod tree, golden; or yerva mora

Rod, shepherd's; or teazel

Roe-buck berries

Root, Indian arrow

Root, China

Root, false China

Root, fever; or Dr. Tinker's weed Triosteum perfoliatum

Root, hollow; or tuberous moschatel

Root, rose

Root, snake, of Virginia

Root, snake, black or wild of $\}$ Virginia

Root, sweet; or liquorice

Rosa-solis

Rose

Rose, China

Rose, Christmas; or black helle- ? bore

Rose, Gelder; (a variety from marsh elder)
Adoxa moschatellina

Rhodiola rosea Aristolochia serpentaria

Actoa racemosa

Glycyrrliza glabra

Drosera rotundifolia

Rosa

Hibiscus rosa (sinensis)

Helleborus niger

Geraniam robertianum

Allium scorodoprasum

Cistus

Brassica eruca

Reseda lutea

Sisymbrium silvestre

Bunias orientalis

Bunias erucago

Sisymbrium silvestre

Sisymbrium

Sisymbrium murale

Cornus sanguinea

Solidago virga-aurea

Bosea yerva-mora

Rubus sexatilis

Maranta arundinacea

Smilax china

Viburnum opulas (fiore pleno)
Cactus spinosissimus 
Rose, dog; or hep Rosa canina

Rose, Virginian Gelder, with a $\}$ Spircea opulifolia

Rose, Japan

Camellia japonica

Rose, Martinico;
China rose

Rose, musk

Rose, rock

Rose of Jericho

Rose of Sharon* (see St. John's ? wort)

Rose bay; or oleander

Rose bay, dwarf or mountain

Rose bay willow herb

Rose mallow; or hollyhock

Rose-root

Rose-wood

Rosmary (from ros-maris)

Rosmary ; or poet's cassia

Rosa moschata

Cistus

Anastatica hierochuntica

Rosmary, wild; or marsh cistus

Rosmary, lesser wild

Roucou

Rue; or herb of grace

Rue, dog's

Rue, goat's, common

Hypericum calycinum

Nerium oleander

Rhododendrum hirsutum

Epilobium angustifolium

Alcea rosea

Rhodiola rosea

Aspalathus

Rosmarinus officinalis

Osyris alba

Ledum palustre

Andromeda polifolia

Mitella

Ruta graveolens

Scrophularia canina

Galega officinalis

Rue, meadow ; or feathered co-
lumbine

Rue, common yellow meadow

Rue, wall; or scent-wort

Rue, wild Assyrian

Ruffle, lady's -

Rupture-wort

Thalictrum aquilegifolium

Thalictrum flavum

Asplinium ruta muraria

Peganum harmala

Lychnis

Herniaria

Rupture-wort, leâst ; or all-seed

Rush

Linum radiola

Rush, sea

Juncus

Juncus acutus†

* Canticles, chap. ii. ver. 1.

+ Juncus acutus, and juncus inflexus, are both nsed in Holland for the support of the sea banks, as also for making baskets, mats, \&c.; and are used in England (where they are also natives) for bottoming chairs, \&c.-They grow from four to six or seven feet in hight ; the first hath the panicle terminal, and the other lateral.- The sand reed (arundo arenaria) is also used for the above purposes; and in Iceland, the seed is dried and ground for bread. 
Push, bull

Rush, soft or candle

Rush, flowering; or water gladiole Butomus unbellatus

Rush, lesser flowering

Rush, round black-headed,marsh, ?

or bog

Rush, sweet; or calamus aromaticus Acorus calamus

Rye, common

Rye or ray grass; or wild rye

Secale cereale

Lolium perenne
Scirpus lacustris

Juncus effusus
Scheachzeria palustris

Schoenus nigricans

$\$$

Sabin

Sabin tree, Indian

Saffron

Saffron, base ; or safflower

Saffron, meadow; or naked ladies

Saffron, mountain spring

Sage, common garden

Sage of virtue, narrow-leaved (a variety)

Sage, purple or red-topped

Sage, wild or wood

Sage, Indian wild

Sage, Jerusalem; or sage tree

Sago

St. John's bread; or carob tree

St. John's wort, * common

St. John's wort of Constantinople, or great-flowered; or rose of Sharon

Juniperus sabina

Bauhinia aculeata

Crocus satious

Carthamus tinctorius

Colchicum autumnale

Bulbocodium vernum

Salvia officinalis

\}Salvia officinalis

Salvia horminum

Teucrium scorodonia

Lantana aculeata

Phlomis fruticosa

Cycas circinalis

Ceratonia siliqua

Hypericum perforatum

Hypericum ascyron, or calycinum $t$

St. John's wort, shrubby ; or tutsan Hypericum androsamum

St. John's wort, warted

St. John's wort, Chinese

St. Peter's wort; or base St.
John's wort St. Peter's wort

Hypericum balearicum

Hypericum monogynum

Hypericum quadrangulare

* It is called St. John's wort, as being formerly usual on the vigil of St. John to place sprigs of it at the entrance into houses, to keep out witches and evil spirits, as the Druids used to do with veronica.

+ Mr. Miller says it is the ascyron, and Mr. Aiton says it is the calycinum. 
St. Peter's wort, shrubby

Saintfoin ; or cock's head

Salack

Salep

Sallad, corn; or lamb's lettuce

Sal-kali ; or jointed glasswort

Sallow,* common

Salsify ; or garden goat's-beard

Salt-wort
Salt-wort, black; sea chickweed; or milk-wort

Sambac; or Arabian jasmine

Samphire; or sea fennel

Samphire, golden

Sandbox, $\uparrow$ or crackling tree; or Jamaica walnut

Sanicle

Sanicle, American

Sanicle, American base

Sanicle, bear's ear

Sanicle, Yorkshire; or butterwort Pinguicula vulgaris

Sandwort,

Sappádillo tree

Sappan-wood

Sapota

Sapota mammee

Saracen's woundwort; or consound Solidago virga-aurea

Saracen's woundwort; or con-? sound, true

Sassafy (see Salsafy)

Satin flower; moon-wort; or honesty

Hura crepitans

Tragopogon porrifolium

\}Lunaria annua
Lonicera symphoricarpis Hedysarum onobrychis

Calamus rotang

Orchis morio

Taleriana locusta

Salicornia herbacea.

Salix caprea

Tragopegon porrifolium

Salicornia herbaceu

Glaux maritima

Nyctanthes sambac

Crithmum maritimum.

Inula crithmifolia

Sanicula europact

\{ Tiarella cordifolia

$\{$ Heuclera americance

Mitella diphylla

Cortusa matholo

Arenaria

Sloanea

Casalpinia sappan

Achras sapota

Achras mammosa

A good brown paper may be made of the bark of sallow in its green state, and may be sold much cheaper than that made of old ropes; that made of ropes is sold at about $8 \mathrm{~s} .6 \mathrm{~d}$. per ream, that made of the withen may be sold at about 5s. 8d. per ream; -and pasteboard for book covers made of ropes, is sold at about $£ 25$ per ton (long hundred), that made from withen-bark may be sold at $£ 17$ per ton.

The above was related by Mr. Graves, Paper-maker, at Mill-Bank near Warrington, in 1788 .

+ See crackling tree. 
Satyrion; or dog-stones

Orchis

Sauce alone; or Jack by the hedge Erysimum alliaria Savin-see Sabin

Sanders, white or yellow

Sanders, red

Savory, comimon

Saw-wort

Saxifrage

Saxifrage, white or granulated

Saxifrage, Burnet

Saxifrage, golden

Saxifrage, meadow

Scabious, common

$\left\{\begin{array}{l}\text { Sanialum album } \\ \text { Sirium myrtifolium }\end{array}\right.$

Pterocarpus santalinus

Satureja hortensis

Serratula

Saxifraga*

Saxifraga granulata

Pimpinella saxifraga

Chrysosplenium

Seseli saxifragum

Scabiosa arvensis $\left.\begin{array}{c}\text { Scabious, hairy sheep's; or ram- } \\ \text { pions with scabious heads }\end{array}\right\}$

Scallion; cibouls; or Welsh onion Allium cepa (cambrica)

Scammony of Montpelier

Sciatica cress; or base mithri-? date mustard

Scordium

Scorpion grass, or caterpillars

Scorpion grass, mouse-ear

Scorpion's thorn; or gorse

Screw tree

Scull or skull cap

Scurvy grass; or spoon-wort

Sea beard

Sea-fans (Zoophytest)

Cynanchum acatum

Iberis

Teucrium scordium

Scorpiurus vermiculate

Myosotis scorpioides

Ulex europous

Helicteres isora

Scutellaria

Cochlearia officinalis

Conferva rupestris

* Saxifraga (from samum a stone, and frango to break), a name given to several plants, which are supposed to have the virtue of breaking or dissolving the stone in the human body.

+ Zoophyies mean animal plants; as corallines, sea-fans, spunge, 8tc. which are generally classed among animals.-As to the androsace (agaricus androsaceus), its place is not yet determined in natural history; Vitaliano Donati calls it a plant; Linnæus says it is a zoophyte, and gives it the name of tabularia acetalulum; according to the Abbe Alberto Fortis, it is one of the subaqueous productions of the valley of Slosella in Dalmatia, but he could not absolutely determine its character, though he could see no evident marks of its being a zoophyte.

Travels in Dalmatia, 4 to. printed in 1788.

The sensitive plants (whose sensibility is not perfectly accounted for) seems to hold the connection between real plants and zoophyses, and the zoophytes between sensitive plants and real animals; but Dr. Darwin thinks the fungi consti-

$2 \mathrm{R}$ 
Sea-grass

Sea-weed

Sedge; or char

Sedum, cobweb

Sedum, saxifrage

Seed, heart

Seed, heart

Segs

Selery* (a variety) see Smallage

Seleriac (a variety)

Self-heal, common

Senna of the shops

Senna, bladder

Senna, Ethiopian bladder

Seana, jointed-podded bladder; or scorpion senna

Sengreen ; or snowy saxifrage

Sensitive fern

Sensitive plant

Sensitive wood-sorrel

Sensitive plant

Sensitive plant

Sensitive plant

Sensitive plant, base

Sensitive tree

Septfoil; or tormentil, common

Sermountain; or laserwort
Ruppia maritimá

Fucus

Carex divisa

Sempervivum arachnoideum Saxifraga sedoides

Brassica vesicaria

Cardiospermum

Iris pseud-acorus

Apium graveolens (dulce)

Apium graveolens

Prunella vulgaris

Cassia senna

Colutea arborescens

Colutea frutescens

Coronilla emerus

Saxifraga nivalis

Onoclea sensibilis

Smithia sensitiva

Oxalis sensitiva

$\left\{\begin{array}{c}\text { Mimosa† sensitiva and } p u- \\ \text { dica }\end{array}\right.$

Hedysurum girans

Dionca muscipula

Eschynomene

Averrhoa carambola

Tormentilla erecta.

Laserpitium siler

tute the istmus between the animal and vegetable kingdoms, as they partake of both. They can exist without light or much air ; and the odour of a fungus when burning, smells like burning feathers, and they putrefy like animal flesh : and it is said a weak broth for an invalid, may be made by a little catchup mixed with thin gruei, with shred parsley and a little salt, so as to deceive the taste. It is also as. serted by Van Humboldt, that he converted morels into fat, by sulphuric acid and water, which seems analogous to that formed from muscular flesh.-See Phytologia, p. 486 and 301.-Botanic Garden, p. 42.- See also Rousseau's Letters on the Elements of Botany, under the word truffle.-See note to lycoperdon.

* Selery is generally spelt celery, but as it is derived from the Greek, it ought to be selery.

Skinner's Etymolo. Ling. Anglicanæe.

+ Mimosa sensitiva and pudica are both sensitive plants, and are biennial; the first shews its sensibility, when touched, by the collapsing of the leaflets only; the second is called the humble sensitive, by the collapsing of the leaflets and footstalk. 
Serpent's or adder's tongue

Serpentine tree

Service tree

Service, maple-leaved, or wild

Sesame; or oily grane

Sesame, Italian

Setwall, garden; or valerian

Setterwort; bear's foot; or helleboraster

Shaddock; or pampelmoe

Shallot (see Eschalot)

Shave grass

Shepherd's needle; or Venus's comb Scandix pecten

Shepherd's purse

Shepherd's rod; or teazel

Shepherd's rod, smaller

Shot, Indian; or Indian cane

Sickle-wort

Sidesaddle flower

Silk cotton tree

Silk, Virginian

Silver bush; or Jupiter's beard

Silver tree

Silver weed

Simpla nobla; or base shrubby hare's ear

Simpler's joy; or common vervin

Skirret

Sky flower

Sloe tree

Sloke

Smallage; or water parsley

Snail trefoil

Snake's head

Snake weed

Snake-root, Virginian

Ophioglossum

Ophyoxylum serpentinum Sorbus domestica

Cratogus torminalis

Sesamum orientale

Astragalus sesameus

Valeriana phu

Hellibórus fatidus

Citrus decumana

Allium ascalonicum

Equisetum hyemale

Thlaspi bursa pastoris

Dipsacus fullonum

Dipsacus pilosus

Canna indica

Coronilla

Sarracena

Bombax gossipinum

Periploca greeca

Anthyllis barba jovis

Protea argentea

Potentilla argentea

Phyllis nobla

Verbena officinalis

Sium sisarum

Cineraria

Prunus spinosa

Ulva

Apium graveolens

$\{$ Medicago polymorpha (scutellata)

Iris tuberosa

Polygonum bistorta

Aristolochia serpentaria

Snake-root, black or wild of America Act ca racemosa

Snake-wood

Snap tree

Snap-dragon

Snap-dragon of America
Ophioxylum serpentinum

Justicia hyssopifolia

Antirrhinum

Ruellia tuberosa 
Sneeze-wort; or goose-tongue Snceze-wort, Austrian

Snow-ball tree; or Gelder rose

Snowberry bush

Snowdrop

Snowdrop, Summer

Snowdrop tree

Snowy mespilus

Soap apple, or berry
Aclillea ptarmica

Xeranthemum anmum

$\{$ Viburnum opulus (flore

pleno)

Chiococeo racemosa

Galanthus nivalis

Leucojum astivum

Halesia tetraptera

Mespilus canadensis

Sapindus saponaria

Soap-wort, or bruise-w ort, common Saponaria officinalis

Soda*

Soldanel

Soldier, water ; or water aloe

Soldier's cullions

Solomon's seal

Solomon's seal of America

Sorgo; or Indian millet

Sorrel; or green-sauce

Sorrel, French or Roman

Sorrel, wild

Sorrel, Indian ; or ocra

Sorrel, wood

Sorrel, sensitive wood

Sorrel tree

Sorrowful, or melancholy tree

Sour sop
Salsola soda

Soldanella alpina

Stratiotes aloides

Orchis pyramidalis

Convallaria polygonatum

Uvularia

Holcus sorghum

Rumex acetosa

Rumex scutatus

Riumex acetosella

Hibiscus esculentus

Oxalis acetosella

Oxalis sensitiva

Andromeda arborea

Nyctanthes arbor tristis.

Annona muricata

* Soda is an alkali extracted in the same manner as pot-ash alkali, but hat some very different properties; soda, as obtained from marine plants, is usually entirely saturated with carbonic acid, doth not attract the humidity of the atmo. sphere like pot-ash, but desiccates, and is converted into a white powder.-Lavoisier's Elements of Chemisty. It will not, therefore, make good pot ash, but is used in glass, \&c.

Soda is now chiefly obtained from a mineral fixed alkali, found in Egypt, Persia, and Arabia; and in its crude state, in commerce, is called soda, or larilla. When it is obtained from vegetables, it is only from those which grow upon the sea side, or salt lakes, and especially from the plant kali, from whence the name, to which the Arabians add al (the) by way of eminence, as they do to the Koran, and we to the Bible.-It is a very curious fact, that the ashes of all plants growing at a distance from salt water, afford the vegetable alkali, or pot-ash (used for making glass, soap, \&c.), "while such as grow near the sea, or on borders of salt lakes, afford the fossil alkali, or soda; if, however, these same plants are cultivated in the interior of the country, they produce pot-ash only. - See note to alkali in the Index, 
Southern-wood; or lad's-love Sow-bread

Soy; or kidney bean of India Sparrow-wort

Sparrow-wort, Tragus's

Spear-wort, great

Spear-wort, small

Speerage-see Asparagus

Speedwell

Speedwell, male; or fluellin

Speedwell, female

Speedwell, water; or brooklime

Spice-wood

Spice, all; or pimento

Spice, Virginian all

Spider-wort

Spider-wort, great Savoy; or St. Bruno's lily

Spider-wort, Virginian

Spignel, common; or meum

Spignel, wild; or French hartwort Seleli

Spignel, base

Spikenard, Indian

Spikenard, true Indian

Spikenard, base French

Spikenard, or nard, Celtic

Spikenard, false; or lavender

Spikenard, plowman's; or groundsel tree
Artemisia abrotanum

Cyclamen

Dolichos soja

Passerina

Stellera passerina

Ranunculus linqua

Ranunculus fiammula

Veronica

Veronica officinalis

Antirrhinum elatine

Veronica beccubanga

Laurus

Myrtus pimenta

Calycanthus floridus

Anihericuri

Anthericum liliastrum

Tradescantia virginica

Ethusa meum

Athamanta

Nardus indica

Andropogon nardus

Nardus

Valeriana celtica

Lavendula spica

\} Baccharis halimifolia

Spikenard, plowman's; or fleabane Coniza squarrosa

Spikenard, wild; or asarabacca

Spinach, common

Spinach, rock

Spinach, strawberry; or blite

Spindle tree; or prick or skewer

wood

Spindle, or staff tree, climbing

Spindle tree, base

Spiræa frutex*

Asarum europaum

Spinacia oleracea

Beta maritima

Blitum capitatum

Euonymus

Celastrus scandens

Kiggellaria africana

Spircea salicifolia

* The young shoots of the spirce a frutex being very tough and pliable, are often psed for the tops of fishing rods. 
Spiræa, African

Spleen-wort, common

Spleen-wort, rough

Spleen-wort, rough

Spoon-wort; or scurvy grass

Spunge (a Zoophyte)

Spunk

Spurge; or milk-wort
Diosma

Asplenium ceterach

Lonchitis hirsuta

Polypodium asplenifolium

Cochlearia officinalis

Agaracus

Euphorbia Spurge, four-parted umbellated
French; or caper

Euphorbia lathyris

Spurge, common sun; or wart-wort Euphorbia helioscopia

Spurge laurel; or dwarf bay

Spurge olive

Daphne laureola

Daphne olenides

Spurry, or sperry, common corn Spergula arvensis

Squash; or buckler gourd

Squill; or sea onion

Cucurbita melopepo

Scilla muritima

Squill, lesser white; or sea daffodil Pancratium maritimum

Squinanch

Staff or spindle tree, climbing

Staff, shepherd's; or teazel

Stag's-horn tree

Asperula cynanchica

Celastrus scandens

Dipsacus fullonum

Rhus typhinum

Stagger or staverwort; or ragwort Senecio jacoboa

Star of Bethlehem

Star-flower, low and small

Ornithogalum pyramidale

Ornithogalum umbellatum

Star of Arabia and Constantinople Ornithogalum arabicum

Star of Naples

Star grass; or starry duck meat

Star-wort; or aster

Ornithogalum nutans

Callitriche

Star-jelly ; star-shot; or nostoc

Star-wort, base

Aster

Tremella nostoc

Star-wort, trailing American' Tradix procumbens

Star-wort, yellow; or elecampane Inula helenium

Stavesacre; or lousewort

Stickadow; or French lavender Lavendula stochas

Stitch-wort; or star-flower, greater Stellaria holostea

* This plant is very much cultivated in Brabant, Holland, and Germany, as food for cattle, both when green and made into hay.

+ Though Linnæus hath given it the spe fic name of umbellatum, it ought to have been corymliosum, for that is its mode of flowering; it seems very careful of its embryo, by the flowers shutting up very close, early in the evening, and in bad weather. 
Stitch-wort, lesser

Stink-horns

Stock July-flower

Stock, annual, or ten-weeks

Stonecrop; or wall pepper

Stork's bill

Stramonium ; or thorn apple

Stramonium, purple-stalked; or tatula

Strawberry $\uparrow$

Strawberry, barren

Strawberry, barren

Strawberry blite; or spinach

Strawberry tree, common $\$$

Strawberry tree, oriental

Succory-see Cichory

Sugar cane

Sugar palm

Sulphur-wort; or hog's fennel, common

Sultan flower; or sweet sultan

Sumach

Sumach, myrtle-leaved

Sumach, tanner's

Sumach, Venice

Sundew

Sun-flower, common annual

Sun-flower, perennial

Sun-flower, base or willow-leaved
Stellaria graminea

Phallis impudicus

Cheiranthus

Cheiranthus annuus

Sedum acre

Pelargonium*

Datura stramonium

Datura tatula

Fragaria vesia

Fragaria sterilis

Potentilla montpeliensis

Blitum capitatum

Arbutus unedo

Arbutus andrachne

Saccharum officinarum

Arenga saccharifera

Peucedanum officinale

Centaurea moschata

Rhus

Coriaria myrtifolia

Coriaria ruscifolia

Rhus cotinus

Drosera

Helianthus annuns

Helianthus multiforas

Helenium autuminale

* Pelargonium grandiflorum (great-flowered) makes a very grand appearance, with leaves large, funnel-form.

+ Linnæus derived great benefit under the attacks of the gout, to which he was subject, from the use of strawlerries; a plate of which he found greatly relieved him. He had a periodical return of the disorder for a few years afterwards, but always slighter and slighter by the use of his remedy; and, by perseverance, was at last actually cured.

Dr. Maton's edition of Pultney's View of the Writings of Linnæus, 1805.

¥ The fruit of the common strawberry tree is eaten in Iceland, but is apt to have a lethargic effect: it is a beautiful evergreen tree, and flowers in Autumn, either red or white; and the fruit of the former year is then ripe, for the fruit is a whole year growing to perfection. 
Sun-flower, small American

Sun-flower, small, of Carolina

Sun-flower, little; or dwarf cistus

Sun-flower, Mariland tickseeded

Sun-fruit

Sunn, or sunn hemp

Supple jack

Swallow-wort

Swallow-wort, African; or lesser ? cockscomb frittillary.

Sweet John; and sweet William

Sweet sop; or chirimoya

Sweet sultan

Rudbeckia hirtu

S Polymnia tetragonothed

\{ Rudbeckia purpurea

Cistus helianthernum

Coreopsis verticillata

Heliocarpus americance

Crotalaria juncea

Paullinia polyphylla Asclepias vincetoxicum

Stapelia variegata

Dianthus barbatus

Annona squamosa

Centaurea, moschata

Sweet William; and sweet John Dianthus barbatus

Sweet William, Indian; or qua- $\}$ moclit

Swine's cress

Ipomoea quamoclit

Sycomore, true; or Pharaoh's?

fig tree
Sycomore or plane, false; or greater maple*

Syringa $; \dagger$ or mock orange

Cochlearia coronopus

Fivus sycomorus

Acer pseudo-píaianis

Philadelphus coronarius

T

Tacamahaca (a resin)

Tallipot tree

Tallow tree

Tamarind tree

Tamarisk

Tansey, common

Tansey, wild; or goose grass

Tapioca

Tare, or vetch with black seed

Tarragon; or dragon-wort

Tarton-raire

Tartarian lamb

Populus balsamifera

Licuala spinosa

Croton sebiferum

Tamarindus indica

Tamarix gallica

Tanacetum vulgare

Potentilla anserina Jatropha manihot

Vicia sativa Artemisia dracunculus Daphne tartonraira

Polypodium barometz

* See note to ficrs, pr 169 .

+ Syring a was a name formerly given to the mock-orange; but as Linnows has made that name the genus to lilac, it must now be exploded. 
Tea tree, bohea

Tea tree, green

Tea, base

Tea, New Jersey

Tea, base Chiną, with a leaf like Jamaica pepper

Tea, Labrador

Tea, Oswego; or Indian balm

Tea, Paragua, South Sea, or Y apon

Tea of St. Domingo

Tea, Siberia

Teak-wood; or Indian oak

Teazel, fuller's; or shepherd's rod Dipsacus fullonum*

Teazel, small

Tent-wort; or wall rue

Terra japonica-see Catechu

Thistle

Thistle, common corn $\uparrow$

Thistle, blessed; or carduus benedictus

Thistle, carline, $\ddagger$ common

Thistle, distaff

Thistle, distaff, yellow

Thistle, fish

Thistle, globe, common

Thistle, golden

Thistle, bedge-hog:

Thistle, lady's, spotted milk, or boly Carduus narianus

Thistle, marsh
Thea bohea

Thea viridis

Rhamnus theezans

Ceanothus americanus
Camellia japonica

Ledum latifolium

Monarda didyma

Cassine paragua

Capraria bisflora

Tectona grandis

Dipsacus pilosus

Asplenium rutu muraria

Carduus

Carduus arvensis

Cnicus acarna

Carlina vulgaris

Atractylis

Carthamus lanatus

Carduus casabona

Echinops spinosus

Scolymus

Cactus mammillaris

Carduus palustris

Rhododendron chrysanthum

*: Dipsacus fullonum (fuller's teasel or teazel) consists of two varieties: the one is the common teazel, which Mr. Aiton calls dipsacus sylvestris (but Dr. Murray gives that name to a different species), with the awns of the palea straight; the other is the cultivated teazel (dipsacus sativus), used by fullers for dressing their cloth, with the awns of the palea hooked or recurved.

+ The common corn thistle, according to Linnæus, is called a sau-wort (serratula arvensis); but, according to Curtis, and also Smith (who has lately publiched a Flora Britannica, : 801 ), it is brought back to its old name a thistle.-Carduzs is distinguished from serratula by its hairy receptacle, bellied calyx, and its prickly scales, and by its stigma less two cleft.

$¥$ Carline thistle is said to take its name from the Emperor Charles the Great, whose army was preserved from the plague by the use of the root of it.

Skinner's Etymolo. Ling. Anglicanæ. 
Thistle, melancholy

Thistle, melon

Thistle, soft, or gentle

Thistle, solstitial, or Barnaby

Thistle, sow ; or hare's lettuce

Thistle, downy sow; or woolly? hawkweed

Thistle, torch

Thistle, woolly, or cotton

Thistle, woolly-headed

Thongs

Thorn apple

Thorn, black

Thorn, box

Thorn, Christ's

Thorn, Egyptian ; or acacia

Carduus helenivides

Cactus melocactus

Carduus dissectus

Centaurea solstitialis

Sonchus oleraceus

Thorn, evergreen; or pyracantha Mespilus pyracantha

Thorn, goat's; or tragacanth

Thorn, lily

Thorn, purging

Thorn, scorpion's; or gorse

Thorn, Spanish hedge-hog

Thorn, white; or hawthorn

Thorny plant, burning

Thorough wax

Three-leaved grass

Thrift ; or sea pink

Throat-wort, greater

Throat-wort, lesser

Throat-wort, blue umbelliferous

Thyme, common

Thyme, lemon, (a variety) from

Thyme, dodder of

Thyme, mastich

Andryala lanata

Cactus

Onopordum acanthium

Carduus eriophorus

Fucus loreus

Datura stramonium

Pruras spinosa

Lycium

Rhamnus spina christi

Mimosa nilotica Astragalus tragacantha

Catesbaa spinosa

Rhamnus catharticus

Ulex europæus

Anthyllis erinacea

Cratagus oxyacantha

Euphorbia

Bupleurum rotundifolium

Trifolium

Statice armeria

Campanula latifolia

Campanula glomerata

Trachelium caruleum

Thymus vulgaris

Thymus serpyllum

Cuscuta epithymum

Thymus mastichina

Thyme, mother of; wild thyme; or basil

Tickseed sun-flower

Thymus serpyllum

Tickseed

'Tiger's-foot

Tinker's (Dr.) weed; fever-root ; Tithymale or false ipecacuana

Coreopsis verticillata.

Corispermum

Ipomoea pes tigridis

Triosteum perfoliatum

Euphorbia tithymaloides 
Toad, or paddock-stool

Toad-flax; or calve's snout

Toad grass

Tobacco

Tolu tree, balsam of

Tomatoes

Tongue-blade; or tongue laurel

Tooth-ache, or pellitory tree

Tooth-pick; or visnaga

Tooth-wort ; or coral-wort

Tooth-wort; or lead-wort

Tormentil ; or septfoil, common

Touch me not; or yellow jasmine

Touch me not; or spurting cu-? cumber
Agaricus

Antirrhinum linaria

Bufonia tenuifolia

Nicotiana tabacum

Toluifera balsamum

Solanum peruvianum

Ruscus hypoglossum

Zanthoxylum clava herculis

Daucus visnaga

Dentaria bulbifera

Plumbago europaa

Tormentilla erecta*

Traveller's joy ; or old man's beardClematis vitalba

Tree everlasting

Tree moss

Trefoil

Trefoil, bean tree

Trefoil, common hare's foot

Trefoil, stinking bean

Trefoil, hedge-hog

Trefoil, bird's-foot; or lamb toes

Trefoil, bird's-foot

Trefoil, winged bird's-foot

Trefoil, marsh; or bog-bean

Trefoil, moon

Trefoil, shrub

Trefoil of Montpelier, shrub

Trefoil, snail

Trefoil, thorny, of Candia

Trefoil tree; or laburnum

Trichomanes

True love; or herb paris
Gnaphalium arboreum

Lichen usnea

Trifolium

Cytisus laburnum

Trifolium arvense

Anagyris fotida

$\left\{\begin{array}{c}\text { Medicago polymorpha(in- } \\ \text { tertexta) }\end{array}\right.$

Lotus ornithopodioides

Trifolium ornithopodioides

Lotus tetragonolobus

Menyanthes trifoliata

Medicago arborea

Ptelia trifoliata

Lotus dorycrium

Medicago prostrata

Fagonia cretica

Cytisus laburnum

Asplenium trichomanes

Paris quadrifolia

* Black ink which smells like a rose, it is said may be obtained by a decoction of the tormentilla erecta; it is made in the usual method; the proportion is three arachms of vitriol to a decoction made with seven ounces of water.

Annales de Chymie, 1791 . 
True love; or herb paris of America Trillium cernuum Truffles Lycoperdon tuber Trumpet flower; or scarlet jasmiae Biguonia radicans Tube rose; or Indian hyacinth Polianthes tuberosu Tulip, common garden

Tulip, wild yellow

Tulip, African ; or blood-flower Tulip, checquered

Tulip tree

Tulip tree, laurel-leaved

Tupelo tree

Turkey feather

Turk's cap; or martagon

Turk's head

Turk's turban

Turmeric

Turnep

Turnep, French

Turn-hoof; or ground ivy

Turnsol; or wart-wort

Turnsol, sweet-scented

Turpentine treé

Turpeth garganic

Tussubakki

Tutsan; or park leaves Hypericum androsonum

Tulipa gesneriana

Tulipa syloestris

Hornanthus coccineus

Fritillaria meleagris

Liriodendrum tulipifera

Magnolia grandifiora

Nyssa aquatica

Ulva favonia

Lilium martagon

Cactus

Ranunculus

Curcuma longa

Brassica rapa

Brassica napus

Glechoma hederacea

Heliotropium

Heliotropium peruvianum

Pistacia terebinthus

Thapsia garganica

Camellia japonica

Twopence, herb; or money-wort Lysimachia nummularia

Twa, or twy blade

Twy blade; or blood-flower

Twining plants - see Class Diadelphia

Ophrys ovata

Homanthus coccineus

Valerian, or setwall, garden

Valeriana phu

Valerian, Greek; Jacob's ladder; $\}$ or charity

Vanilla, or venelloe Epidendrum
Varnish tree; or poison ash or oak Rhus vernix

Polemonium coruleum.

Venus's comb; or shepherd's needleScandix pecten

Venus's looking glass

Camparula speculum

Venus's navel-wort (see navel-wort) Cynoglossum lusitanicum

Venus's hair

Vernal grass, sweet-scented Adianthum cupillus veneris Anthoxanthum odoratum 
Vervain

Virbena

Vervain, common; or simpler's joy Verbena officinalis

$V$ ervain, mallow

Vetch; or tare

Malva alcea

Vicia sativa

Vetch, axe, or hatchet

Vetch, bitter

Coronilla securidaca

Vetch, bitter; or heath peas

Eroum ervilia

Vetch, jointed-podded bitter

Orobus sylvaticus

Erounc lens

Vetch, chichling

Vetch, crimson grass

Vetch, Clusius's foreign hatchet

Vetch, horse-shoe

Vetch, kidney; lady's finger; or ? wound-wort

Vetch, liquorice

Vetch, knobbed-rooted liquorice

Vetch, milk

Vetch, base milk

Lathyrus clymenum

Lathyrus nissolia

Bisserrula pelecinus

Hippocrepis

Vetch, Venetian bitter

Vetch, medic

Vetchling

Vetchling, yellow

Viburnum

Viburnum, American

Anthyllis vulneraria

Astragalus giycyphyllos

Glycine apios

Astragalus

Phaca

Orobus

Hedysarum

Astragalus onobrychis

Lathyrus aphaca

Viburnum

Lantana

Vine tree, common

Vine, Canadian

Vine, black; or black bryony

Vitis vinifera

Gaultheria procumbens

Vine, climbing five-leaved, of $\mathrm{Ca}-$ -

nada; or Virginian ivy, or $\}$ Hedera quinquefolia
creeper

Vine, Spanish arbour

Ipomoea tuberosa

Vine, white; or white bryony Bryonia alba

Violet, common

Violet, bulbous ; or snowdrop

Violet, Calathian

Vioía odoraía

Galanthus nivalis

Gentiana pneumonanthe

Violet, dame's; rocket; or queen's ? July flower

Violet, dog's-tooth

Violet, or milfoil, water

Viper's grass

Virgin's bower, purple

Hesperis matronalis

Erythronium dens canis

Hottonia palustris

Scorzonern

Clematis viticella 
Viorna, leathery-flowered virgin's bower

Visnaga; or tooth-pick

Umbrella tree

Upas, bohon*

Uva ursi; or bear berries

Urine-wort

Uraick-see Wrack

\}Clematis viorna

Daucus visnaga

Magnolia tripetala

Cestrum

Arbutus uva ursi

Saxifraga hirculus

W

Wagebroom

Wake robin; or cuckow pink

Wall-flower

Walnut tree

Walnut, Jamaica; sandbox tree; or crackling tree

-Walnut, Virginian ; or hiccory

Wall-wort; dane-wort; or dwarf elder

Wanhom

Ware, sea

Wart-wort

Protea argentea

Arum maculatum $\dagger$

Cheiranthus cheiri

Juglans regia

Hura crepitans

Juglans alba

Sambucus ebulus

Kampferia

Fucus vesiculosus

Wart-wort; or common sun spurge Euphorbia helioscopia

Wart-wort; or turnsol

Wart-wort; or nipple-wort

Water-leaf

Water-wort

Wayfaring, or pliant mealy tree

Weed, sweet ; or wild liquorice

Weld; wold; or base rocket

Wheat, common lammas $\ddagger$

Heliotropium

Lapsana communis

Hydrophyllum

Flatine hydropiper

Viburnum lantana

Capraria biflora

Reseda lutea

Triticum hybernum

\footnotetext{
* The romantic stories of the excessive poison of the bahon upas, are said not to be well founded.

+ The root of the arum maculatum, which is a native of Britain, in its recent state is very acrimonious, but when thoroughly dried, becomes a farinaceous aliment, and may be made into wholesome bread; it is also prepared as a starch; and when dried and powdered, it is used by the French to wash the skin, as a cos. metic, which is sold at a high price under the name of Cypress powder: these roots are also said to possess a saponaceous quality, and have been used instead of soap, for washing linen.
} 
Wheat, buck or beech; ${ }^{*}$ brank; $\}$ Polygonum fagopyrum
or helxine

Wheat, meadow cow

Wheat, Egyptian

Wheat, Trukey; or Indian maize

Whin; furze; or gorse Whin, petty; cammock; or rest-
harrow

Whin, petty; or small broom

Whip-thong tree

Whistles, sea

White beam; white leaf tree; or aria theophrasti

White, or milk wood

Whitlow grass

Whitlow grass, common

Whitlow grass, rue-leaved

Whortle-berry; red-worts; or bilberry

Whortle-berry; or bladder nut, African

Melampyrum pratense

Triticum compositum

Zea mays

Ulex europæus

Genista anglica

Crassula imbricaia

Fucus nodosus

Cratagus aria

Bignonia leucoxylon

Draba

Draba verna

Saxifraga tridactylites

Vaccinium myrtillus

Royena

Whortle-berry, with flowers single $V$ accinium vitis idaęa

Whorts, bog or moor; or cranberry

Whorts, Spanish red; or straw-

Vaccinium oxycoccos berry tree

Wicken; quickbeam; mountain ? ash; or roan tree

Widow-wail

Widow, weeping

Willow

Arbuius unedo

Willow, French; or willow herb

Willow, golden, or yellow

Sorbus aucuparia

Cneorum tricoccon

Willow, spiked, of Theophrastus

Willow, or gale, sweet

Fritillaria meleagris

Salix

Epilobium angustifolium

Salix vitellina

Spirca salicifolia

Myrica gale

Willow herb; or purple loosestrife Lythrum salicaria

Willow herb; or yellow loosestrife Lysimachia vulgare

* Buck wheat is probably a corruption for leech wheat, the seeds of each beirg: similar, and from the old name fagopyrum.-See beech wheat.

Skinner's Etymolo. Ling. Anglicinæ.-Universal Mag. for Nov. 1786, p. 233. 
Willow herb, rosebay

Willow, weeping

Wind-fiower; or anemone

Wind-seed

Winter-berry

Winter-bloom

Winter-green, common

Winter-green, ivy-flowering

Winter-green, with chickweed flowers

Woad; or pastel, common

Woad, wild; or dyer's or yellow weed

Wolf's bane; or aconite

Wolf's claw

Woodbind; or honeysuckle

Woodbind, Spanish; or arbour vine

Wood of life; or lignum vitæ

Woodroof

Wood-waxen ; or dyer's broom

Wooginoos

Worm-grass

Worm-seed, officinal

Wormwood

Wormwood, Roman or Pontic

Wormwood, sea

Wormwood; wild; or base feverfuge

Woundwort of Achilles

Woundwort; or kidney vetch

Woundwort, clown's ; or allheal

Woundwort; consound, Saracen's ; or golden rod

Woundwort, true Saracen's

Wrack

Wrack; or nraick grass
Epilobium angustifolium

Salix babylonica

Anemone

Arctotis aspera

Prinos verticillatus

Azalea

Pyrola rotundifolia

Kalmia

Trientalis europoea

Isatis tinctoria

\} Reseda luteola

Aconitum

Lycopodium

Lonicera periclymemun

Ipomoea tuberosá

Guaiacum officinale Asperula odorata

Genista tinctoria

Brucea antidysenterica

Spigelia anthelmia

Artemisia santonica

Artemisia absinthium

Artemisia pontica

Artemisia maritima

Parthenium hysterophorus

Achillea

Anthyllis vulneraria

Stachis palustris

\} Solidago virga aurea

Senecio sarracenicus

Fucus

Zostera marina

Y

Yam, or yaum; or Indian po-
tatoe 
Yam, Pelew

Arum esculentum

Yapon; cassina; or South sea tea Cassine paragua

Yarrow (see Milfoil)

Yellow-root

Yellow-weed; or wild woad Achillea millifolium Hydrastis canadensis

Yerva mora; or golden rod tree

Yew-tree, common Reseda luteola

Yellow-wort; or perfoliate centaury Bosea yerva mora Taxus baccata Chlora perfoliata

Z

Zacintha; warted nipple-wort;
or cichory Zedoary, round Zedoary, long; or galangal Zerumbet; or wild ginger Zoophytes-see page 305. Kampferia rotunda Kampferia galanga Amomum zerumbet

$2 T$ 



\section{A TABLE}

OF

\section{VEGETABLE DRUGS,}

NOT IN THE INDEXES。

A NISEED

Assafortida (a resin)

Balaustines; or pomegranate

Bdellium (a gum resin)

Benzoin, or Benjamin (a resin)

Burgundy pitch (a resin) Camboge, or gamboge (a gum
resin)

Canella alba

Caranna (a resin)

Cardamom seed

Cassia fistularis

Cassia lignea

Castor oil Caoutchonc
resin) * or gum elastic (a J Jatropha elastica
Pimpinella anisum

Ferula assafoctida

Panica granatum

Malachra capitata

$\{$ Laurus benzoin

Terminalia benzoin

Pinus abies
Cambogia gutta

Canella alba

Amomum cardamomum

Cassia fistula

Laurus cassia

Ricinus communis

* Caoutchouc is obtained from the inspissated juice of several other plants besides the jatropha elastica; as from a creeping plant in Prince of Wales's Island, and from another plant in Sumatra, called by W. Roxburg, M. D. urceola elastica.The Abbe Rochon in his Voyage to Madagascar, printed 1791, says, they have a plant called finguere, a kind of wild fig-tree, which 'produces by incision a milky juice, which, when coagulated, becomes a true elastic gum, like the caoutchouc; that they make flambeaux of it which burn without wick, and give a good light in their nocturnal fishing :-and a fossil hath lately been discovered in the the East Indies exactly resembling the cuoutchouc resin in all its principal properties (except that the cohesion of its parts is weaker); it is chiefly found amongst spars and Fead-ores; a small quantity of which hath also been lately found in Derbyshire, 
Cochinil (see Kermes)

Colombo*

Cursuta $\uparrow$

Dragon's blood (a gum resin)

Elaterium

Euphorbium (a gum resin)

Frankincence; or olibanum resin)

Galbanum (a gum resin)

Gum ammoniacł (a gum resin)

Gum anime (a resin)

Gum arabic (a gum)

Gum baubaul

Gum copal (a resin)

Gum elemiई (a resin)

Gum guajacum (a resin)

Gum ladanum (a resin)

Gum lac\| (a resin)
Cactus cochinillifer

Gentiana purpurea

$\{$ Dracana draco

$\{$ Pierocarpus draco

Momordica elaterium

Euphorbia antiquorum
Juniperus lycia

Bubon galbanum

Ferula

Hymeraa courbaril

Mimosa nilotica

- Rhus copallinum

Amyris elimifera

Guajacum officinale

Cistus ladaniferus

Rhamnus ziziphus

and is supposed originally to be of vegetable production.-Amber and amtergris, though ranked amongst the fossil bitumen, are also supposed to proceed from vegetables.-Tar is also not only obtained from coal, but issues from copious springs? both in England and Germany.-Barilla or saphora is also found near Bombay, in a bed of ferrugineous clay, and is said to be well adapted for hard soap, medical uses, and plate glass.

* A tincture from the root of colombo is much recommended as an agreeable stomachic bitter.

+ Cursuta is a word which found its way into the Edinburgh Dispensatory, from a Norway ship once bringing a quantity of it to Edinburgh, where the root was used with good success as a bitter; and its etimology is supposed to be from a: corruption of skar-söte (mountain soot), the Norway name for gentiana purpurea. - It is a native of Savoy.

Smith's Tour on the Continent, v. iii, p. 157, printed 1793.

¥ The gum-ammoniac beetle, called in Morrocco diblen fashook, perforates the plant, and makes incisions, whence the gum oozes out; it seems to be nearly the same insect which Mr. Bruce calls zimb, or $\log f y$.

$\S$ Bursera gummifera affords a resin no way different from the gum elemi of the shops.

II Mr. Robert Saunders, Surgeon at Boglepoor in Bengal, in his account of the vegetable and mineral productions of Boutan and Tibet, hath shewn that gum lac is the production or nidus of an insect, called coccos, or kermies lacca, on a species of rhamnus, which is imported into this country from the East Indies under three forms, which are called stick, seed, and shell lac; the first of these exhibits the substance in its natural state. 
Gum sandarach, called pounce (a $\}$ Juniperus communis
resin)

Gum seneg̀a (a gùm)

Gum tragacanth (a gum)

\section{Hermodactyls}

Jew's ear

Mimosa senegal Astragalus tragacantha*

\{Colchicum variegatum

$\{$ Iris tuberosa

Peziza auricula

\section{Kino (a gum)}

$\left.\begin{array}{c}\text { Liquidamber; liquidstorax; } \\ \text { gum sweet (a resin) }\end{array}\right\}$ Liquidamber styracifua

Mace

Manna (a gum)

Mastich (a resin)

Myrobalans

Myrrh (a gum resin)

Oleum rhodii

Opobalsamumt

Opium (a gum resin)

Opoponax (a gum resin)

Origanum, oil of

Pareira brava

Pyrethrum

Sago (the pith of the palm tree)"

Sagapenum (a gum resin)

Salep

Sarcocolla (a gum resin)

Sarsaparilla

Sassafias

Scammony (a gum resin)

Sebesten; or Assyrian plum

Soldanel; or sea bindweed

Spike, oil of

Styrax; storax calamita; or 2

Myristica officinalis

Fraxinus rotundifolia

Pistacia lentiscus

Spondias myrobalanus

Aspalathus

Amyris opobalsamum

Papaver somniferum

Pastinaca opoponax

Origanuini vulgare

Cissampelos pareira

Anthemis pyrethrum

Cycas circinalist

ferula orientalis

Orchis morio

Penca sarcocolla

Similax sarsaparilla

Laurus sussufrias

Conoolvulus scammonios

Cordia sebestevia

Convolvulus soldanella

Lavandula spica

Jew's frankincense (a resin) $\}$ Siyrax officinalis

* See note to astrugalus.

+ See note to amyris.

\$. Cycas is called a palm, but Linnæus hath placed it under the order filices, in the class cryptogamia; but Mr. Aiton places it amongst the palms.-The true sago powder is from the pith of the cycus circinalis; but what is often sold for such is only the starch of potatoes. 
Terebinth; or chio turpentine'

Terra japonica

Turpeth-root

Venice turpentine (a resin)
Pistacia terebinthis

$\left\{\begin{array}{l}\text { Mimosa catechu } \\ \text { Area catechu }\end{array}\right.$

Convolvulus turpethums

Pinus larix.

FINIS.

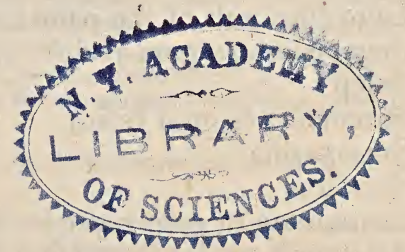

Printed by M. HAGE, Newark. 


\section{ADDITIONAL NOTE TO MYRISTICA.}

If you begin to grate a nutmeg at the stalk end, it will prove hollow throughout; whereas if you begin to grate it at the other end, it will prove sound and solid to the last. The centre of a nutmeg consists of several fibres issuing from the stalk only, without adhering to other parts of the fruit; that as the stalk is grated away, they fall out, and leave the nutmeg hollow.Another caution worth knowing, is, that as the oil of nutmegs is very valuable, it is often extracted from the nuts that are exposed to sale, which renders them of little value; to discover which, force a pin into them, and if good, however dry they appear, the oil will be seen oozing out round the pin.

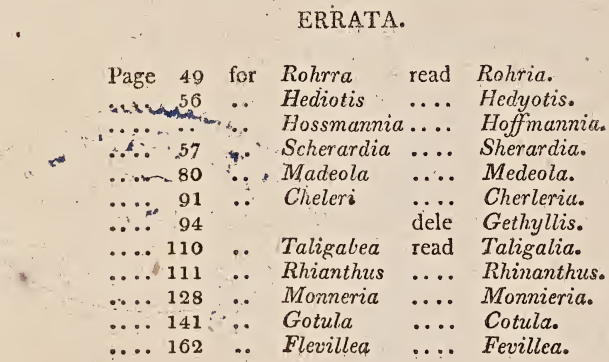

N. B. In the Table of Classes and Orders, at page 38 , the 7 th order to $P_{Q-}$ iyandria should be Decagynia, and an 8 th order to be added called Polygy. - mia; it will then agree with the class Polyandria. 
, 






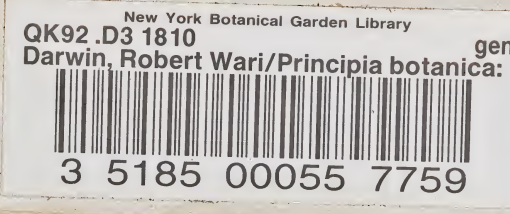




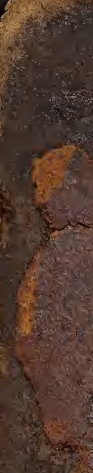

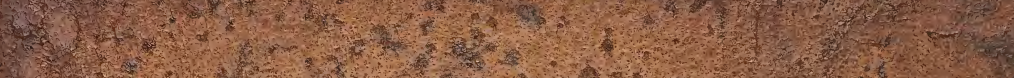

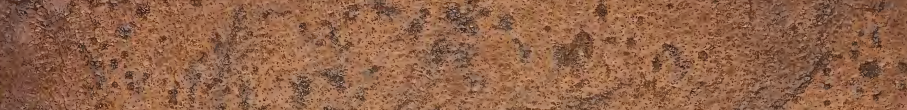

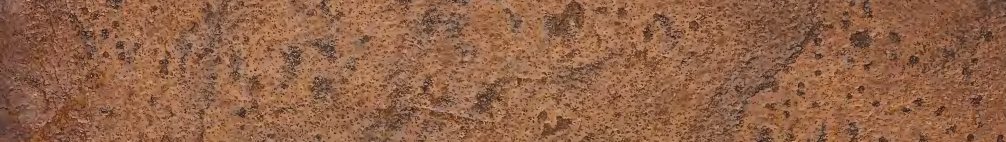

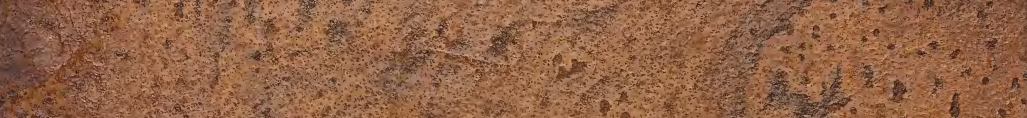

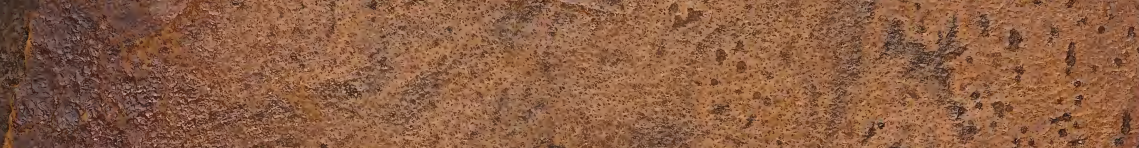

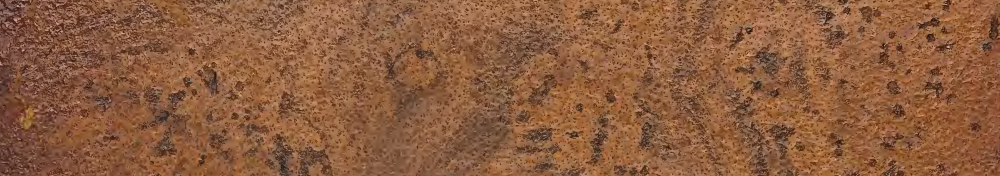

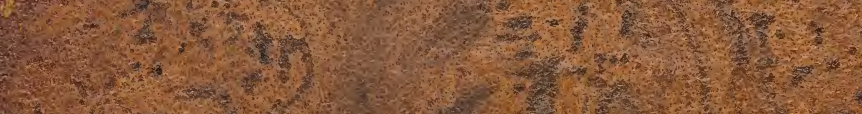

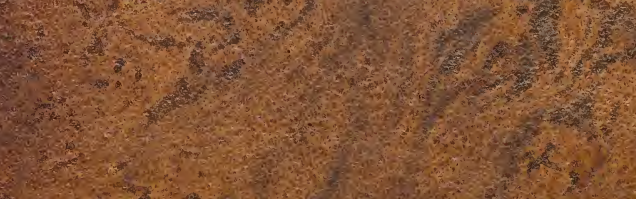

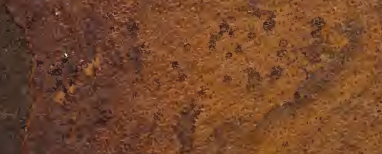
(15) 13.4.

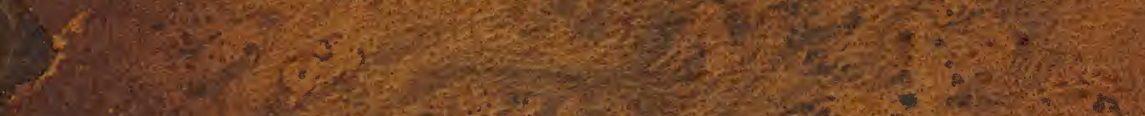

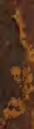

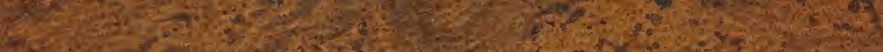

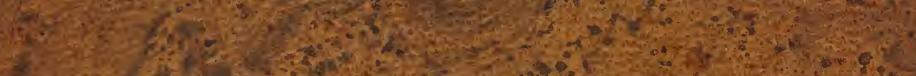

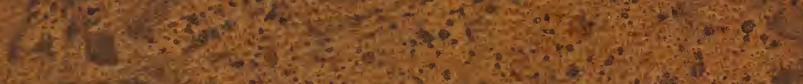

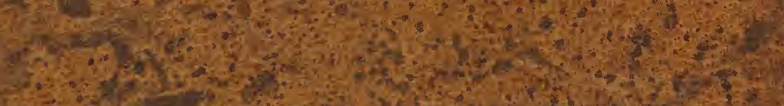

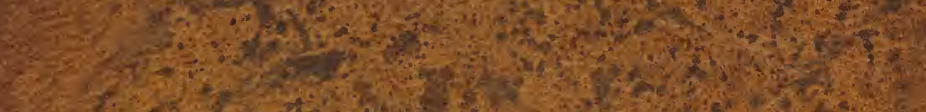

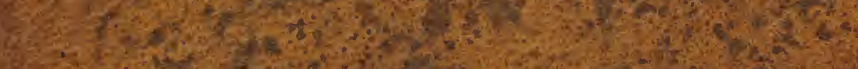

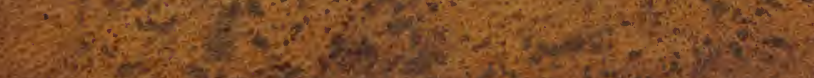

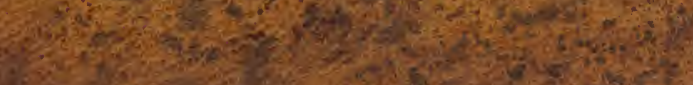

